UNIVERSIDADE DE SÃO PAULO

FACULDADE DE DIREITO

PROGRAMA DE PÓS-GRADUAÇÃO STRICTO SENSU

DEPARTAMENTO DE DIREITO PROCESSUAL

VITOR BURGO

O IMPACTO DO FEDERALISMO FISCAL NO PROCESSO DE CONTROLE JURISDICIONAL DE POLÍTICAS PÚBLICAS

São Paulo - SP 
Vitor Burgo

\section{O IMPACTO DO FEDERALISMO FISCAL NO PROCESSO DE CONTROLE JURISDICIONAL DE POLÍTICAS PÚBLICAS}

Tese de doutorado
apresentada como requisito
parcial para a obtenção do
título de Doutor da
Faculdade de Direito da
Universidade de São Paulo,
sob a orientação da
Professora Titular Ada
Pellegrini Grinover.

São Paulo - SP 
Vitor Burgo

\title{
O IMPACTO DO FEDERALISMO FISCAL NO PROCESSO DE CONTROLE JURISDICIONAL DE POLÍTICAS PÚBLICAS
}

Tese apresentada ao Programa de Pós-Graduação em Direito Processual da Faculdade de Direito da Universidade de São Paulo como requisito para obtenção do grau de Doutor em Direito.

\author{
Aprovada em
}

COMISSÃO EXAMINADORA

Profa. Titular Ada Pellegrini Grinover

Faculdade de Direito da Universidade de São Paulo

Orientadora

Prof.

Prof.

Prof.

Prof. 
A Helena, pela grandiosidade do amor devotado à construção de nossa família. Amor que não se pede, que não se mede, que não se repete.

A minha mãe, meu pilar mestre, fonte de minha força e meu destemor.

Ao meu irmão, sempre disposto, sempre a postos, sempre irmão.

Ao Carlos, pelo carinho e por toda ajuda que somente um pai poderia dar. 


\section{AGRADECIMENTOS}

A Ada Pellegrini Grinover, pela generosidade com que devota seu tempo e seus conhecimentos aos seus alunos, pela seriedade na condução de seu ofício de orientadora e pela gentileza no trato com seus orientandos. É tão bom poder agradecê-la novamente!

A Samuel Meira Brasil Jr., pelos exemplos infindáveis, colhidos todos os dias, em cada pequeno gesto.

Aos Professores da Faculdade de Direito da Universidade de São Paulo, a quem agradeço em nome de Régis Fernandes de Oliveira, Virgílio Afonso da Silva, Kazuo Watanabe, José Maurício Conti, Fernando Facury Scaff e Susana Henriques da Costa, que fizeram efetiva diferença em minha formação.

Aos servidores da Faculdade de Direito da Universidade de São Paulo, pela presteza e cordialidade com que nos atendem.

Aos meus colegas e amigos de Doutorado, a quem agradeço em nome de Elizabeth Martos e Eloísa Machado de Almeida.

A Marcos Vinícius Pinto, Daniel Mazzoni, Karla Valladão Lugon Mazzoni, Paula Fajardo Maia, Sarita Zotelle Lubiana, Viviane Ferrari Rodrigues, Roberta Cristina Guarçoni Brito, Maria Tereza Vasconcellos do Valle, Hugo Giuberti Cibien, Luiz Gustavo Sueth Berriel, José Adriano Pereira e Rosangela Maria Pretti Dalcolmo pela amizade.

A Rodrigo Maia Bachour, Mariana Santos de Queiroz Araújo e Luiza Álvares da Silva Campos, pela parceria profissional.

A Anderson Sant'anna Pedra, pela solicitude e generosidade.

A Conceição, Norleide, Cláudia e Humberto, pelo apoio espiritual recebido em cada momento de maior dificuldade.

A Conceição e Carlos (Carlão), sempre atentos ao meu menor sinal de fraqueza.

A minha querida avó Josefa, por tão grande amor.

A Leonídia, pela dedicação de toda uma vida.

A Família Lima Gomes, por ter me acolhido com tanta paciência. 


\section{RESUMO}

A opção pela forma federativa de governo importa em compromisso com a existência de mais de um ente responsável, em territórios sobrepostos, pela realização das tarefas de arrecadação e gasto público, além de suas inerentes atividades políticas. O exercício dessas tarefas pode ser definido com rigor, em um regime dual, ou com possibilidade de auxílios mútuos, em um regime de cooperação. O Brasil adotou, como cláusula pétrea em sua Constituição, a forma de federação cooperativa, estruturada em três níveis de governo, tendo como consequência a divisão de competências materiais entre os componentes dessa federação. Apesar disso, os Tribunais brasileiros têm insistido em sustentar a tese de solidariedade obrigacional entre todos os entes federados em processo que tenham por objeto o controle de políticas públicas sociais. A imposição dessa obrigação solidária, além de desrespeitar a estrutura federativa e afrontar os princípios da efetividade e economicidade da administração - com sobreposições e sobrecargas que facilitam o desperdício de verbas e a corrupção - ainda não atenta para a regra de ouro da imposição de solidariedade obrigacional, que é a menção expressa em dispositivo legal ou constitucional. Conforme será demonstrado, as decisões proferidas pelos Tribunais nacionais em sede de controle jurisdicional de políticas públicas vem ignorando todo o arcabouço jurídico acerca do tema, além de impor aos entes federados desnecessária dificuldade de gestão de suas competências e de seus recursos financeiros. A defesa de responsabilidades divididas, porém, poderia gerar efeitos nefastos. É que, em sede processual, a demanda ajuizada em face do ente não diretamente responsável pela execução da política pública questionada poderia ser extinta sem resolução do mérito, impondo atrasos à efetivação de direitos sociais decorrentes de óbices processuais. Como os direitos fundamentais - categoria na qual estão inseridos os direitos sociais - exigem efetivação imediata e são sindicáveis judicialmente a partir dos comandos genéricos dados pela Constituição, foi preciso recorrer a uma técnica antiga - já prevista no Brasil, porém mal compreendida - de integração subjetiva da demanda por ordem do juiz, a intervenção iussu iudicis. Para evitar a repetição de erros, será refeito o caminho histórico de surgimento e desenvolvimento dessa técnica para melhor compreensão de seus escopos. 


\begin{abstract}
The option for the federal form of government matter commitment to the existence of more than one entity responsible, in overlapping territories, for performing the tasks of public collection and spending beyond their inherent political activities. The exercise of these tasks can be defined rigorously, in a dual system, or with the possibility of mutual aid, in a regime of cooperation. Brazil has adopted as entrenchment clause in its Constitution, a cooperative federation, structured in three levels of government, resulting in the division of powers between the material components of this federation. Nevertheless, the Brazilian Courts insisted on supporting the thesis of a mandatory solidarity among all federal entities in the suits whose purpose is the control of public policies. The imposition of such solidarity, besides disregarding the federal structure and defy the principles of effectiveness and economy of administration - with overlays and overloads that facilitate waste of money and corruption - not attentive to the golden rule imposing mandatory solidarity, which is the expressly stated in law or constitutional provision. As will be shown, the decisions handed down by national courts in the seat of judicial control of public policies has ignored the whole legal structure of the topic, and impose to federal entities an unnecessary difficulty in managing their skills and their financial resources. The defense of divided responsibilities, however, could generate adverse effects. Is that in procedural field, a suit filed in the face of an entity not being directly responsible for the execution of the questioned public policy demand could be terminated without resolution, imposing delays to the realization of social rights under procedural obstacles. As fundamental rights - the category in which they belong social rights - require effective immediately be investigated and are chargeable from generic commands given by the Constitution, it was necessary to resort to an old technique - already foreseen in Brazil, but poorly understood - a subjective integration demand by the judge's order, the intervention iussu iudicis. To avoid repeating mistakes, will be redone historical path emergence and development of this technique to better understand their scopes.
\end{abstract}




\section{RÉSUMÉ}

Le fait que le gouvernement brésilien soit une fédération a pour conséquence l'existence de plusieurs responsables, à des niveaux superposés, pour collecter les impôts et réaliser les dépenses publiques, en plus des activités politiques. L'exercice de ces fonctions peut être défini avec rigueur dans un régime dualiste, ou avec la possibilité d’aides mutuelles dans un régime de coopération. Le Brésil a adopté, comme clause immutable dans sa Constitution, le statut de fédération coopérative, structurée en trois niveaux de gouvernement, ayant comme conséquence la division des compétences matérielles entre les composants de cette fédération. Malgré cela, les tribunaux brésiliens insistent à soutenir la thèse de solidarité obligatoire entre tous les agents fédérés en procès qui ont pour objet le contrôle des politiques publiques sociales. L'imposition de cette obligation solidaire, en plus de ne pas respecter la structure fédérative et d'affronter les principes d'effectivité et d'économie de 1' Administration - avec la superposition et la surcharge qui facilitent le gaspillage de l'argent public et la corruption - n'observe pas la règle d'or de l'imposition de solidarité obligatoire, qui est la mention expresse dans un dispositif légal ou constitutionnel. Comme il sera démontré, les décisions proférées par les tribunaux nationaux, sièges de contrôle juridictionnel des politiques publiques, ignorent les règles juridiques sur le thème, en plus d'imposer aux agents fédérés une difficulté inutile de gestion de leurs compétences et de leurs ressources financières. La défense des responsabilités partagées, cependant, pourrait gérer des effets néfastes. C’est que, un procès contre un agent de la fédération qui n'est pas directement responsable de l'exécution de la politique publique en question, n'aurait pas accès à un examen de fond, imposant des retards, résultats des problèmes de procédure, à l'effectivité des droits sociaux. Comme les droits fondamentaux - catégorie dans laquelle sont insérés les droits sociaux - exigent une effectivité immédiate et sont soumis judiciairement à cause des dispositions constitutionnelles, il a été nécessaíre de recourir à une technique ancienne déjà prévue au Brésil, mais mal comprise - d’intégration subjective de la demande par ordre du juge, l'intervention iussu iudicis. Pour éviter la répétition des erreurs, il sera refait le chemin historique de l'apparition et du développement de cette technique pour une meilleure compréhension de ses finalités. 


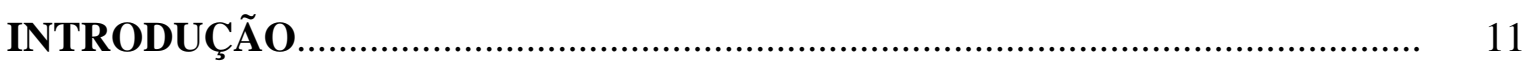

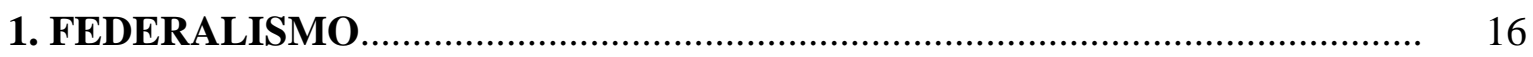

1.1. FEDERALISMO COOPERATIVO........................................................... 20

1.1.1. Federalismo cooperativo brasileiro ………………………………………... 23

1.1.1.1. Fortalecimento do Poder Central............................................................... 24

1.2. FEDERALISMO FISCAL......................................................................... 27

1.2.1. Transferências voluntárias......................................................................... 29

1.3. A INSERÇÃO DO TEMA NO DEBATE SOBRE A JUDICIALIZAÇÃO DAS 30

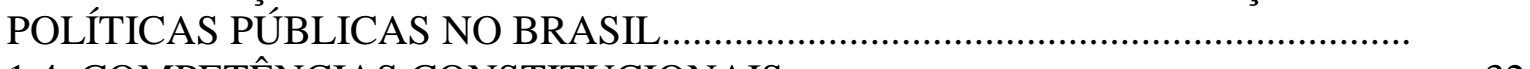
1.4. COMPETÊNCIAS CONSTITUCIONAIS............................................................ 32

1.4.1. Competências materiais................................................................................... 33

2. A JUDICIALIZAÇÃO DOS DIREITOS SOCIAIS ……………………………... 38

2.1. PROCESSOS JUDICIAIS E A QUESTÃO ORÇAMENTÁRIA........................... 43

2.1.1. A constitucionalização do sistema orçamentário brasileiro............................ 44

2.1.2 As necessidades públicas.............................................................................. 4

2.1.3. Os princípios da eficiência e da economicidade............................................. 53

2.1.4. A atuação do Poder Judiciário no planejamento e execução de políticas 54 públicas em um contexto federalista..

2.2. DIREITO À SAÚDE.................................................................................... 56

2.3. DIREITO À EDUCAÇÃO.............................................................................. 75

2.4. EFETIVAÇÃO DOS DIREITOS SOCIAIS E O PRINCÍPIO DA LEALDADE 79 FEDERATIVA...

2.5. O ANTEPROJETO DO CEBEPEJ................................................................. 88

3. O PROCESSO E O CONTROLE JURISDICIONAL DE POLÍTICAS 93 PÚBLICAS

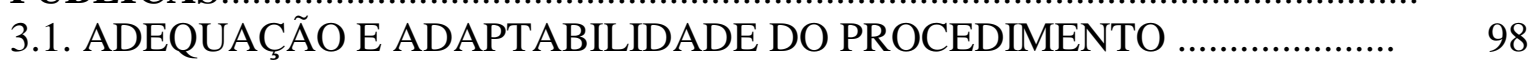

3.1.1. Princípios da adaptação e adequação ……………………………………...... 102

3.1.1.1. Proposta do novo CPC....................................................................... 105

3.1.1.2. Processo de interesse público: modificação da estrutura tradicional................. 106

3.1.1.2.1. Experiência argentina............................................................................. 114

3.1.1.2.2. Experiência colombiana....................................................................... 116

3.1.2. Os princípios dispositivo e da imparcialidade do juízo como limitadores 119 dos poderes do juiz......

3.1.3. Princípio da imparcialidade ................................................................... 120

3.1.4. Princípio dispositivo.................................................................................. 121 
3.1.5. Princípio da demanda.

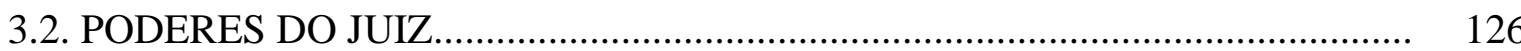

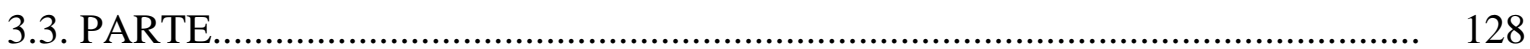

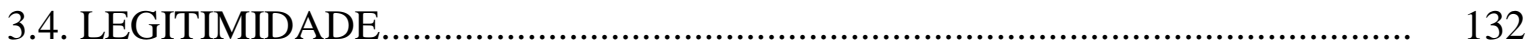

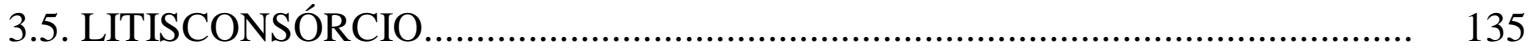

3.5.1. Litisconsórcio unitário ou comum............................................................. 137

3.5.2. Litisconsórcio necessário e facultativo ......................................................... 138

3.5.3. Litisconsórcio e o princípio da demanda....................................................... $\quad 140$

3.6. INTERVENÇÃO DE TERCEIROS................................................................ 141

3.6.1. Intervenções voluntárias e provocadas..................................................... 142

3.6.1.1. Intervenções voluntárias............................................................................ 142

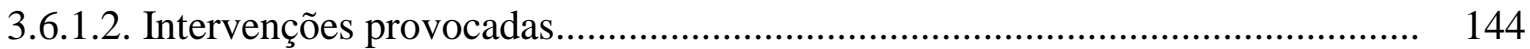

3.7. INTERVENÇÃO IUSSU IUDICIS ............................................................ 146

3.7.1. Evolução histórica do instituto.................................................................... $\quad 150$

3.7.2. Reflexos sobre o princípio da demanda....................................................... 162

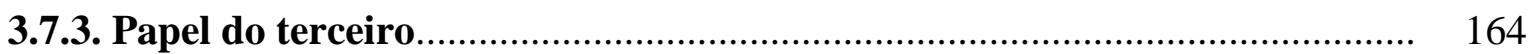

3.7.4. Proposta de novo código de processo civil italiano..................................... 165

3.7.5. Intervenção iussu iudicis na França......................................................... 165

3.7.6. Intervenção iussu iudicis no Brasil............................................................. 168

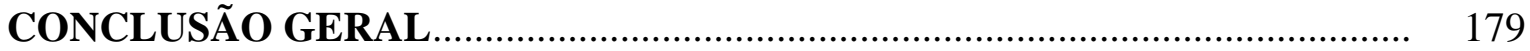

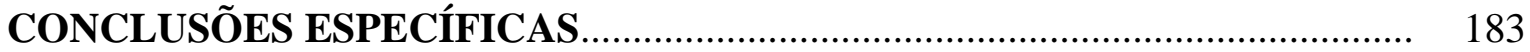

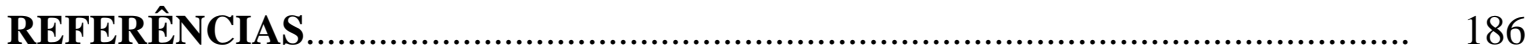




\section{INTRODUÇÃO}

O presente estudo enquadra-se dentro dos múltiplos esforços que vem sendo realizados por instituições governamentais e grupos acadêmicos de pesquisa para conseguir identificar os limites e as formas de atuação do Poder Judiciário no controle do planejamento e da execução das políticas públicas elaboradas pelo Poder Executivo.

A crescente exigência jurídico-social de efetividade da Constituição da República Federativa do Brasil de 1988, com o atendimento, em especial, dos direitos fundamentais sociais $^{1}$ trouxe o problema latente da intromissão do Poder Judiciário no cotidiano da Administração, com impactos relevantes na estrutura orçamentária.

Embora "a intervenção judicial nessa área ocorre em razão da ligação, direta ou indireta, com políticas públicas ser característica marcante do próprio direito contemporâneo" ${ }^{2}$, a forma como ela é posta em prática tem causado estranhamento entre os Poderes constituídos.

Conforme destacado no sítio virtual do STJ, "a premissa inaugurada na Constituição de 1988 de que a saúde é um direito do cidadão e um dever do Estado arrombou as portas dos tribunais para chamada judicialização da saúde" ${ }^{3}$. O direito à saúde, como apresentado, é o exemplo mais vistoso desse processo que tem se delineado de forma cada vez mais nítida porém incerta - no horizonte jurídico brasileiro.

Há uma clivagem natural entre os agentes do Poder Executivo e os do Poder Judiciário, conforme atesta a postura do senador Tião Viana, ao nominar temerosa a postura ativista

\footnotetext{
1 Benefícios sociais ou individuais coletivamente fruíveis, nas palavras de LOPES, José Reinaldo de Lima. Direitos Sociais, teoria e prática. São Paulo: Ed. Método. 2006. p. 120.

2 SALLES, Carlos Alberto de . Políticas públicas e processo: a questão da legitimidade nas ações coletivas. In: BUCCI, Maria Paula Dallari. (org.). Políticas Públicas: reflexões sobre o conceito jurídico. $1^{\text {a }}$ ed. São Paulo: Saraiva, 2006. p. 177.

3 Notícia publicada no sítio virtual do STJ no dia 04 de abril de 2010, sob o título "Judicialização da saúde coloca ao STJ o desafio de ponderar demandas individuais e coletivas". Acesso em 05 de abril de 2010.
} 
do Judiciário nesse tema, pela razão de que uma decisão judicial suplantaria o pensamento técnico e político de gestão da saúde ${ }^{4}$.

A preocupação da substituição do critério técnico por decisões jurídicas é recorrente e merece ser, igualmente, abordada. O orçamento público, ferramenta econômico-contábil de controle das receitas e despesas da Administração, contém, por determinações legais ${ }^{5}$ e constitucionais, a fragmentação das dotações de receita, sendo inviável a formulação de dotações globais, a teor do disposto no art. $5^{\circ}$, da Lei 4320/61.

Esse dispositivo legal carreia um princípio basilar da teoria do orçamento público, qual seja, da especialização ou discriminação da despesa. Em reforço à previsão mencionada, foi editada em 1999 a Portaria Ministerial n. 42, com a intenção de dar "consistência aos programas de trabalho como ações de planejamento e de orçamentação de competência das entidades governamentais" ${ }^{6}$. Quer dizer, a alocação e utilização de recursos públicos devem obedecer às estruturas orçamentárias, que serão utilizadas de acordo com as opções feitas pelo dirigente do executivo, em respeito aos comandos imperativos emanados da Constituição Federal, mais especificamente, ao seu art. $3^{\circ}$.

Nesse ponto cruzam-se a parcela de discricionariedade do administrador e os preceitos constitucionais primordiais, que, em nosso entender ${ }^{8}$, estão contidos justamente no art. $3^{\circ}$ da Constituição. É preciso compreender que as determinações constitucionais devem ser cumpridas sem engessamento da dinâmica democrática.

\footnotetext{
4 Trecho da notícia publicada no sítio virtual do STJ no dia 04 de abril de 2010, sob o título "Judicialização da saúde coloca ao STJ o desafio de ponderar demandas individuais e coletivas". Acesso em 05 de abril de 2010.

5 Apresentam-se fundamentais a Lei ordinária n. 4.320/64, a Lei Complementar n. 101/00, as Leis de Diretrizes Orçamentárias e as Leis Orçamentárias Anuais.

6 MACHADO JR., José Teixeira; REIS, Heraldo Costa. A lei 4.320 comentada. 31. ed. rev./ atual/ Rio de Janeiro: IBAM, 2002/2003. p. 20.

$7 \quad$ Sobre a sustentabilidade voltada ao cumprimento dos objetivos fundamentais da República, v. JACOB, Cesar Augusto Alckmin. A "reserva do possível": obrigação de previsão orçamentária e de aplicação da verba. In: GRINOVER, Ada Pellegrini; WATANABE, Kazuo [coord.] . O Controle Jurisdicional de Políticas Públicas. 2. ed. Rio de Janeiro: Forense. 2013. p. 256. "Todo esse esforço institucional voltado à estabilidade e à responsabilidade visou - e visa -, sem dúvida, ao escopo maior do Estado, que é o desenvolvimento sustentável, capaz de tornar viáveis os objetivos fundamentais previstos no artigo $3^{\circ}$ da Constituição Federal. Em outras palavras, importa refletir sobre a impossibilidade de realização dos desígnios constitucionais sem que se faça o devido planejamento responsável do agir do Estado, do qual não se poderá apartar o respeito quase religioso aos orçamentos públicos".

$8 \quad$ Com base no bem estruturado argumento formulado por GRINOVER, Ada Pellegrini. O controle de políticas públicas pelo Poder Judiciário. In: GRINOVER, Ada Pellegrini. O Processo... 2. ed. rev.ampl. São Paulo: DPJ, 2009.
} 
O Poder Judiciário busca ganhar foros de legitimidade, em todas as suas esferas, para uma atuação mais assertiva no controle das políticas públicas. Amicus curiae, audiências públicas e sessões televisionadas unem-se às decisões fundamentadas como uma tentativa de arejamento de suas estruturas e aproximação das camadas sociais tradicionalmente excluídas.

Porém, falta-lhe trilhar o caminho ao encontro dos Poderes Executivo e Legislativo, que seria construído pelo conhecimento e manejo das leis orçamentárias. Surge aí necessidade de o Judiciário compreender de que maneira são processadas as opções da Administração e em que medida elas cumprem ou infringem o fundamento legitimante de sua própria atuação, qual seja, a efetividade dos direitos fundamentais e o atingimento dos objetivos fundamentais da República ${ }^{9}$.

Em situações nas quais a União disponha de melhores condições (maior arrecadação, melhor infraestrutura, maior accountability) para execução de uma determinada política pública social, será que o Judiciário deveria tratar, como igualmente legitimados e responsáveis pela execução dessa política, os demais entes federativos?

E, do contrário, será que as políticas que demandam proximidade e conhecimento preciso de uma determinada população, deveriam ser exigidas no mesmo grau dos Municípios e da União? O processo deveria ser pensado de acordo com a realidade fática que se apresente no momento em que se pede o controle de uma política pública.

A dificuldade fica por conta das escolhas contraditórias feitas pelo Constituinte e pelo legislador em relação à equação renda e responsabilidade. Os entes subnacionais perderam sensivelmente sua capacidade de investimento com a votação de leis como Kandir,

$9 \quad$ "O implemento concreto dessa nova concepção fica a depender de uma mudança de mentalidade do juiz, que precisa abandonar a antiga postura neutra e desengajada, para, como diz Tércio Sampaio Ferraz Júnior, compreender que hoje ele 'é chamado a exercer uma função socioterapêutica, liberando-se do apertado condicionamento da estrita legalidade e da responsabilidade exclusivamente retrospectiva que ela impõe, obrigando-se a uma responsabilidade prospectiva, preocupada com a consecução de finalidades políticas das quais ele não mais se exime em nome do princípio da legalidade (dura lex sed lex)' [...] 'Ou seja, como o Legislativo e o Executivo, o Judiciário torna-se responsável pela coerência de suas atitudes em conformidade com os projetos de mudança social, postulando-se que eventuais insucessos de suas decisões devam ser corrigidos pelo próprio processo judicial ${ }^{\prime \prime}$. MANCUSO, Rodolfo de Carmago. A Resolução dos Conflitos e a Função Judicial...São Paulo: RT. 2009, p. 259. 
Camata, de Responsabilidade Fiscal ou mesmo de emendas constitucionais, como é o caso da DRU (desvinculação das receitas da União), ao passo que ganharam responsabilidades nas áreas da educação e saúde que seriam superiores aos ingressos de capital.

A alteração da estrutura federativa brasileira é denunciada também por Marta Arretche. De acordo com pesquisas realizadas, o federalismo brasileiro não tem obedecido ao contrato constitucional firmado entre os entes federativos que estabelece proteções mútuas a usurpações por parte dos demais entes e, em especial, da União ${ }^{10}$ - cada vez mais, encarregada do planejamento e coordenação das políticas públicas.

Essa configuração conduz à busca de uma síntese interdisciplinar que permita avaliar os impactos estruturais das opções federalistas no processo judicial, provida de conceitos e princípios próprios às demandas sociais apresentadas no contexto de controle de políticas públicas.

\section{Problema da pesquisa}

O trabalho foi realizado junto ao Programa de Pós-Graduação em Direito Processual da Universidade de São Paulo, que tem dentro de suas linhas de pesquisas incluídos os temas dos estudos dos fundamentos do processo civil moderno, das novas tendências do direito processual civil e das políticas públicas e processos coletivos.

Particularmente, a linha de pesquisa "Políticas públicas e processos coletivos" busca aprofundar os estudos acerca dos instrumentos de tutela dos direitos metaindividuais e suas possíveis interferências nas políticas públicas formuladas pelo Poder Executivo.

Como problema de pesquisa, o estudo buscou responder à seguinte questão: de que forma o processo poderia contribuir para reduzir o impacto financeiro e orçamentário da atuação do Poder Judiciário em sede de controle de políticas públicas?

10 ARRETCHE, Marta. Continuidades e descontinuidades da federação brasileira: de como 1988 facilitou 1995. In: Dados. Rio de Janeiro, vol. 52, nº 2, 2009. pp. 377 a 423. 
A hipótese de trabalho foi a abertura epistemológica do processo civil às peculiaridades das competências constitucionais de arrecadação e realização dessas políticas, absorvendo as ideias advindas do federalismo fiscal.

\section{Objetivos e estrutura da pesquisa}

O trabalho pretende contribuir com uso racional do processo judicial de controle de políticas públicas como forma de diminuir seus efeitos colaterais sobre as contas públicas. Desde o começo destaca-se que as ideias de mínimo existencial e reserva do possível - e o ponto de conflito entre elas - não são importantes para a proposta.

Tem-se por pressuposto a obrigação dos Poderes instituídos em garantir a efetividade das promessas constitucionais, mormente aquelas decorrentes dos objetivos fundamentais da República e dos direitos fundamentais. O objeto do estudo passa pela análise da distribuição de competências e atribuições entre os entes federativos, de forma a possibilitar o direcionamento das exigências sociais - veiculadas por ações judiciais - ao ente diretamente responsável, conferindo-se racionalidade e equilíbrio à própria estrutura federativa.

Os objetivos do trabalho serão, pois: (i) compreender a estrutura do federalismo e identificar a opção do constituinte de 88; (ii) avaliar as competências constitucionais para arrecadação e execução das políticas públicas à luz do federalismo brasileiro; (ii) explicitar a necessidade de um aprofundamento sobre o tema das competências constitucionais e do federalismo fiscal e; (iv) apresentar novas perspectivas ao controle judicial das políticas públicas, em complemento ao Anteprojeto de Lei desenvolvido pelo CEBEPEJ.

Para cumprimento desses objetivos, a presente tese foi dividida em três capítulos, sendo que cada um deles explora uma das fontes de dados utilizada para exposição e análise do problema. Assim, no primeiro capítulo será abordada a estrutura federativa escolhida pela Constituição de 88 para o Estado brasileiro. Já no segundo capítulo serão expostas as razões que autorizam a justiciabilidade dos direitos sociais e a forma como os direitos à saúde e educação são tratados nas cortes superiores do Brasil. No terceiro capítulo, serão apresentados os instrumentos processuais que poderiam ser utilizados pelo Poder Judiciário para otimização dos processos de controle de políticas públicas. 


\section{FEDERALISMO}

Embora falemos em Poderes Executivo, Legislativo e Judiciário, a história do direito constitucional não permite que se conceba a divisão do Poder. Tradicionalmente, diz-se que ele é uno e indivisível. A opção desse trabalho por manter a utilização dessa denominação decorre, primeiramente, de sua consagração. É inegável que o uso seja corrente não apenas nos meios jurídicos, mas por todos aqueles que se referem às instituições em comento.

A outra razão, que justifica a pertinência da abordagem do tema nesse momento, é a possibilidade de divisão do exercício do Poder, que é reconhecido em cada uma das instituições vocacionadas, apesar das diferentes formas de expressão.

Essa divisão pode ocorrer nos planos vertical e horizontal em virtude da especialização que se faça necessária, seja ela temática (Executivo, Legislativo e Judiciário) ou prática (maior facilidade de coordenação ou maior capacidade de execução e fiscalização).

Temos um histórico de Poder que se apresenta como possível nos mais diversos níveis de concentração, seja mais centralizado, em monarquias absolutistas antigas ou predominantemente descentralizado, nos estados federais mais modernos. O nível de centralização pode servir como indício para reconhecimento da forma de organização política de um Estado, desde que esta sirva como ponto de observação.

Isso porque, o movimento centralizador ou descentralizador pode incidir sobre atribuições administrativas ou políticas ${ }^{11}$. Para fins de estabelecimento da forma assumida pelo Estado, se federal ou unitário, o que importa é a existência de múltiplos centros políticos com competência para produção de direito e não meras normas administrativas ${ }^{12}$.

11 Embora BIELSA, Rafael. Princípios de régimen municipal. Buenos Aires: Abeledo-Perrot, 1962, manifeste sua preocupação em relação à simplificação tradicionalmente feita entre as esferas política e administrativa, a divisão atinge didaticamente os fins pretendidos neste trabalho.

12 Para o fim precípuo de se caracterizar a forma de Estado, vale dizer, a forma adotada constitucionalmente para a organização e exercício das competências do Poder Público no território do Estado, o que se leva em conta é, fundamentalmente, o elemento político. É este que determina a criação de um ou mais centros de emanação da ordem jurídica incidente sobre o povo no espaço geográfico de exercício das competências políticas estatais". ROCHA, Carmen Lúcia Antunes. República e Federação no Brasil... Belo Horizonte: Del Rey, 1997. p. 167-8. 
Essas unidades detentoras do exercício legítimo do Poder têm garantidas competência e autonomia para organização própria, de acordo com a previsão feita no pacto originário. Logo, a opção pela divisão vertical importa na distribuição de atribuições e responsabilidades em múltiplos entes políticos ${ }^{13}$. O Estado organizado sob a forma federativa exige a multiplicação de normas legislativas que resulta em um pluralismo jurídico dentro de um mesmo território nacional ${ }^{14}$.

Por essa definição fica mais fácil fugir da armadilha de se achar que descentralização importa em federalismo e centralização em unitarismo. Com o desenvolvimento dos conceitos e a própria experiência dos Estados, houve uma aproximação natural entre os modelos, de maneira que não é difícil identificar estados unitários mais descentralizados que estados federativos.

Essa descentralização, no entanto, é somente de caráter financeiro e administrativo e confere às demais instâncias (não políticas) a responsabilidade exclusiva de execução das políticas locais, ao passo que no sistema federativo, como adverte Augusto Zimmerman, “as funções regionais são efetivamente autônomas, estando o governo regional dotado de órgãos legislativos e judiciários independentes, que possibilitam uma maior participação política de todos os cidadãos"15.

Porque facilita a maior participação do cidadão na vida política do governo, o federalismo tem grande influência na construção de bases mais sólidas para os estados democráticos. Ao arrefecer a concentração de poderes na mão de uma única pessoa ou pequeno grupo seleto e aproximar os centros decisórios do povo, essa estrutura favorece o diálogo entre os verdadeiros detentores do Poder ${ }^{16}$.

\footnotetext{
13 Ou, o contrário, "[...] centralizar é constituir um único centro de decisões, unificar-se o núcleo de tomada de decisões do poder, fixando-se nele o conjunto das competências que poderiam ser fragmentadas ou dispersas em vários centros políticos ou administrativos, dependendo do objeto da organização cuidada. ROCHA, Carmen Lúcia Antunes. Obra citada. 165-6.

14 ZIMMERMAN, Augusto. Teoria Geral do Federalismo Democrático. 2. Ed. Rio de Janeiro: Lumen Juris, 2005. p. 42.

15 ZIMMERMAN, Augusto. Obra citada. p. 42

16 "O devir federalista, ademais, relata à própria concepção limitativa do poder central, aqui entendido como a fonte clássica do poder coercitivo do Estado. Seja como for, o federalismo apresenta-se em oposição invariável ao perigoso sistema de autoridade única, que então se define pelo direcionamento alçado à centralização absoluta do poder político". ZIMMERMAN, Augusto. Obra citada. p. 41.
} 
O pluralismo jurídico mencionado anteriormente, que decorre da produção legislativa nos diferentes níveis de governo não pode ser confinado à estrutura de dominação. Assim como os entes são autônomos, seu produto legislativo também o é, de maneira que não existe hierarquia entre as normas produzidas pelo ente central e aquelas produzidas pelos níveis mais descentralizados de governo, já que ambas extraem seu substrato de validade da repartição de competências feita pela Constituição Federal ${ }^{17}$.

Sendo o federalismo uma construção jurídico-política, sua opção deve estar inserida na Constituição. Nela será definida não apenas a escolha pelo federalismo, mas igualmente, por sua forma ${ }^{18}$. O federalismo pode ser, didaticamente, submetido às seguintes divisões: (i) por agregação ou desagregação; (ii) dual ou cooperativo; (iii) simétrico e assimétrico.

O critério agregação define sua origem, se nascido pela conjunção de esforços de estados preexistentes ou se pela divisão de um ente maior. No Brasil, como sabemos, o federalismo surge por desagregação, já que sua unidade foi garantida desde os tempos da colonização. Primeiro, uma só colônia. Depois, com a Constituição de 1824, um Império. Somente em 1891 é que passa a ser uma federação, formada por seus Estados (art. $2^{\circ}$ da Constituição de 1891).

O critério de simetria avalia a existência de diferenças culturais marcantes em um determinado território nacional. Em não as havendo, a Constituição opta por uma formação federativa simétrica, em que não haja mecanismos de balanceamento de representação. Por outro lado, constatada a pluralidade cultural, o desenho federativo passa a contemplar referidos mecanismos.

Embora esses dois critérios sejam importantes para compreensão do estado federal e para melhor desenvolvimento de suas instituições, neste trabalho eles não exercem influência considerável. As discussões que envolvem apenas tangenciam as premissas e conclusões que serão lançadas, mas não exigem (pela necessidade de delimitação do objeto) aprofundamento teórico.

\footnotetext{
17 ZIMMERMAN, Augusto. obra citada. p. 42.

18 "A preferência do constituinte federal por determinada concepção de Estado Federal e a atuação desses fatores extraconstitucionais irão conduzir, de forma convergente ou não, ao tipo real de organização federal em determinado momento histórico" HORTA, Raul Machado. Direito Constitucional. 2. Ed. rev. atual. ampl. Belo Horizonte: Del Rey, 1999. P. 304.
} 
O que mais importa para o estudo é o critério de distribuição das competências, que separa o estado federal em dual ou cooperativo. Naquele, a separação das atribuições é marcada e estanque. Cada nível é responsável pela criação e pelo desenvolvimento de suas políticas, não havendo colaboração. Já neste, são observadas propositadas zonas cinzentas nas definições de competência, a fim de que se possibilite maior entrosamento e cooperação entre os entes autônomos.

A definição atrai o interesse para o federalismo cooperativo, mas, a verdade é que seu estabelecimento gera uma tensão permanente na unidade federativa, que fica submetida a duas pulsões: pela coesão e pelo particularismo ${ }^{19}$. De acordo com Paulo Bonavides, essa forma é perfeita aos países autoritários porque, a pretexto da função coordenadora do governo central, cria-se um "unilateralismo da decisão" ${ }^{20}$. A fórmula somente pode ser aplicada, com sucesso, em países democráticos se vier acompanhada instituições jurídicas fortes o suficiente para evitar a usurpação de competências ${ }^{21}$.

Esse risco é avistado por toda doutrina constitucional que alerta sobre a fragilidade das descrições constitucionais acerca do modelo de organização do Estado. Para Cármen Lúcia Antunes Rocha, a práxis pode revelar uma forma distinta da prevista no texto constitucional e chegar à atrofia da atuação política dos entes subnacionais mesmo em um contexto federalista ${ }^{22}$.

No Brasil, a Constituição de 88 consagrou o modelo federativo como cláusula intangível pelo constituinte reformador (art. 60, §4, I). De caráter cooperativo, não adotou soluções extremas quanto à distribuição de competências, tendo buscado equilibrar a ordem jurídica do ente central com as dos entes subnacionais ${ }^{23}$.

19 GARCIA PELAYO, Manuel. Derecho constitucional comparado. 8. Ed. Madrid: Revista de Ocidente, 1967. P. 218.

${ }_{20}$ BONAVIDES, Paulo. Curso de Direito Constitucional. São Paulo: Saraiva, 1992. p. 45.

21 "O convívio harmonioso entre o ordenamento federal e os ordenamento estaduais, entre a União e os Estados-Membros, perdura ainda como grande desafio à criatividade técnica do constituinte federal, quando já percorridos mais de duzentos anos de implantação constitucional dessa forma de Estado. HORTA, Raul Machado. Obra citada. p. 304.

${ }_{22}$ Se o modelo de repartição de competências adotado no sistema minguar a atuação política das entidades periféricas do Estado e condenar a um acanhamento, que leve mesmo à quase inexistência a autonomia das ordens jurídicas parciais, não se terá, então, a forma nominada no texto formalizado na experiência dos sistema constitucional. ANTUNES ROCHA, Carmen Lúcia. obra citada. p. 167-8.

${ }_{23}$ HORTA, Raul Machado. Obra citada. p. 468. 


\subsection{FEDERALISMO COOPERATIVO}

Embora a Constituição tenha voltado sua atenção para um sistema complexo de repartição de competências, consagrando sua distribuição entre exclusivas e concorrentes, materiais e legislativas, é a previsão contida em art. 23 que mais nos importa. Em abordagem digna de uma organização federalista multipolarizada, esse dispositivo traz consigo a competência concorrente material de todos os entes federados em relação a temas sensíveis, que devem ser necessariamente objeto de políticas públicas robustas e conjuntas.

Nesse ponto, a Constituição de 88 resgata a tradição das Constituições de 1934 e 1946 ao instituir um federalismo cooperativo, que é o sistema mais adequado para a realização do Estado Social ${ }^{24}$.

O Estado de caráter liberal é marcado pela ausência de interferência do Governo nos mais diversos aspectos da vida social, tendo apenas uma estrutura coordenativa e repressiva ${ }^{25}$ à disposição da sociedade, ao passo que o Estado Social e mesmo o Estado Democrático de Direito passam a ter sob sua responsabilidade uma atuação direta, interventiva, transformadora da realidade social, que gere bem-estar e diminua possíveis desigualdades materiais existentes na sociedade ${ }^{26}$.

Se a convivência sob uma estrutura federativa no Estado liberal permitia aos estados promoverem as políticas locais da forma como lhe aprouvessem, posto que inexistente um controle por parte da União, após o advento do Estado social essa autonomia plena é perdida em favor de uma atuação mais uniforme, ordenada pelo poder central ${ }^{27}$, que reúne

24 BERCOVICI, Gilberto. Dilemas do Estado Federal Brasileiro. Porto Alegre: Livraria do Advogado. 2004. p. 23.

25 Repressão enquanto expressão de força militar, policial.

26 "A transição entre o Estado liberal e o Estado social promove alteração substancial na concepção do Estado e de suas finalidades. Nesse quadro, o Estado existe para atender ao bem comum e, consequentemente, satisfazer direitos fundamentais e, em última análise, garantir a igualdade material entre os componentes do corpo social. Surge a segunda geração de direitos fundamentais - a dos direitos econômicos-sociais -, complementar à dos direitos de liberdade. Agora, ao dever de abstenção do Estado substitui-se seu dever da um dare, facere, praestare, por intermédio de uma atuação positiva, que realmente permita a fruição dos direitos de liberdade de primeira geração, assim como dos novos direitos". GRINOVER, Ada Pellegrini. 2009. p. 37.

$27 \quad$ "Ocorre que, como advento do Estado intervencionista e executor de políticas públicas, as esferas subnacionais passaram a não ter mais condições de decidir e agir, originariamente, sobre inúmeros setores da atuação estatal, que necessitam unidade de planejamento e direção ou um tratamento em escala nacional - 
condições de trabalhar em escala macro para favorecer a coesão e a coerência das políticas adotadas e garantir, simultaneamente, a minimização das desigualdades regionais e dos gastos públicos realizados com essas atividades. Nesse contexto, destaca Wellington Kublisckas $^{28}$, "surgiram duas alternativas de revisão das bases do federalismo visando a atender a necessidade da uniformização de tratamento das matérias objeto da atuação estatal: a centralização e a cooperação".

O Brasil, após experimentar uma forte centralização durante o período militar, optou por uma forma mais descentralizada, que mantivesse, como dito anteriormente, sua unidade por meio de espaços compartilhados de atuação, mas ainda com forte atuação do poder central na orientação dos projetos de formulação de execução de políticas sociais, em virtude do já mencionado comprometimento com a redução das desigualdades regionais.

Como o País tem dimensões agigantadas, seu desenvolvimento não foi uniforme. Em verdade, além da extensão territorial, outros fatores impactaram no subdesenvolvimento de determinadas regiões, como é o caso do Nordeste. A falta de água em grande parte da região contribuiu sensivelmente para a baixa densidade demográfica e menor desenvolvimento de setores industriais e comerciais ${ }^{29}$.

Diante do cenário de desigualdades vivenciado desde a época do Império, o constituinte de 88 decidiu inserir o combate à desigualdade regional no rol de objetivos da República, disposto no art. $3^{\circ}$ da Constituição. Obviamente, para que a intenção não se perdesse em mera promessa, foi necessário construir um sistema que garantisse a arrecadação e

particularmente nos campos econômico e social". KUBLISCAS, Wellington Márcio. Cooperação Interfederativa. Instrumentos para a efetividade da lealdade federativa na Constituição Federal de 1988. Tese de Doutorado defendida no Programa de Pós Graduação em Direito da Universidade de São Paulo. 2012. p. 64.

$28 \quad$ KUBLISCAS, Wellington Márcio. Obra citada. p. 65.

29 Alguns estudos vêm apresentando a seca como apenas um dos problemas que fazem do Nordeste uma região menos desenvolvida, a exemplo: SOARES, Maria de Lourdes. O Nordeste, a Política e a Vulnerabilidade da sobrevivência no Sertão. In: Teoria Política e Social. V.1, n. 1. Dez. 2008. Pp. 133-141. Disponível em:

https:/ /www.google.com.br/url?sa=t\&rct=j\&q=\&esrc=s\&source=web\&cd=4\&cad=rja\&ved=0CEUQFjAD\&url=htt p\%3A\%2F\%2Fperiodicos.ufpb.br\%2Fojs\%2Findex.php\%2Ftps\%2Farticle\%2Fdownload\%2F2958\%2F2519 \&ei=XHwaUtC6JKPB2wWr_4HoCw\&usg=AFQjCNHihJFf11_VTc30bKvmrDLGI65k-

A\&sig2=6TwXc10ea0b8eaZWNc-JkQ 
distribuição de recursos para as áreas mais necessitadas, segundo critérios orientados pela $\mathrm{União}^{30}, 31$.

O papel coordenador do poder central coloca as esferas subnacionais - incluídos nesse rol, os Municípios $^{32}$ - como coadjuvantes no processo de planejamento e execução das políticas públicas sociais $^{33}$, na tentativa de estabelecerem padrões nacionalizados para os serviços básicos de atenção ao cidadão.

A interação entre os entes de uma federação não é, propriamente, uma inovação em termos teóricos e práticos; a grande diferença está no nível de cooperação que passou a ser estabelecido no momento posterior à aparição do modelo social de Estado ${ }^{34}$.

Note-se, pois, que as políticas são desenvolvidas por atuação conjunta e estratégica por todos os entes, mediante atos coordenados pela União, sem que isso represente centralização. A opção do Brasil foi pela descentralização com cooperação vertical, dirigida pelo poder central como forma de homogeneizar os padrões de atendimento em

$30 \quad$ "O caráter centrípeto do Estado de bem-estar social decorre da necessidade de coordenação política nacional para promoção de maior igualdade social, principalmente no aspecto fiscal. Trata-se de redistribuir recursos gerados pelo conjunto da nação, tarefa que envolve um sistema tributário e de repartição das receitas que retira recursos dos mais ricos e os destina aos mais pobres para garantir um padrão mínimo de benefícios a todos os indivíduos, independente da região onde ele esteja localizado" SOARES, Márcia Miranda. Federalismo e desigualdades no Brasil atual. In: TAVARES, André Ramos; BUCK, Pedro [coord.]. Revista Brasileira de Estudos Constitucionais. ano 5, n. 19. julho/setembro 2011. p 144.

31 A exemplo dos critérios de distribuição de recursos previstos para o Fundo de Participação dos Estados (FPE) e Fundo de Participação dos Municípios (FPM).

32 "No Brasil, a Constituição Federal de 1988 adotou claramente os preceitos de federalismo cooperativo ao erigir os municípios como componentes da federação". CARVALHO, André Castro. Mecanismos para a otimização do federalismo fiscal brasileiro. In: CONTI, José Maurício; SCAFF, Fernando Facury; BRAGA, Carlos Eduardo Faraco. Federalismo Fiscal. Questões Contemporâneas. Florianópolis: Conceito Editorial. 2010. p. 166.

33 "O federalismo cooperativo se justifica pelo fato de que, em um Estado intervencionista e voltado para a implementação de políticas públicas, como o estruturado pela Constituição de 1988, as esferas subnacionais não têm mais como analisar e decidir, originariamente, sobre inúmeros setores da atuação estatal, que necessitam de um tratamento uniforme em escala nacional". BERCOVICI, Gilberto. 2004. pp. $56 / 57$.

34 "Não é plausível um Estado Federal em que não haja um mínimo de colaboração entre os diversos níveis de governo. Faz parte da própria concepção de federalismo esta colaboração mútua. Portanto, no federalismo cooperativo, não se traz nenhuma inovação com a expressão "cooperação". Na realidade, a diferença é o que se entende por cooperação, que, no federalismo cooperativo, é bem diferente do modelo clássico de colaboração mínima e indispensável". ROVIRA, Enoch Alberti. Federalismo y cooperacion en la Republica Federal Alemana. Madrid: Centro de Estudios Constitucionales, 1986. pp. 345-346; BERCOVICI. Série Pensando o Direito. No 13/2009. p. 13. Disponível em: http://participacao.mj.gov.br/pensandoodireito/wp-content/uploads/2012/11/13Pensando_Direito.pdf. No mesmo sentido: "A alteração do perfil de atuação do estado, associada ao aumento da complexidade das sociedades em geral, acarretou a intensificação das demandas pela interrelação e interdependência entre os entes federados, na medida em que muitas das questões já não podiam mais ser tratadas de forma eficaz no âmbito exclusivamente regional ou local". KUBLISCKAS. Obra citada. p. 65. 
toda extensão do país, mesmo nas áreas tidas por menos desenvolvidas e mais carentes de recursos pessoais e materiais ${ }^{35}$.

Não há hierarquia ou imposição de ordem de parte da União, competindo a esta apenas a uniformização das políticas que tenham abrangência nacional, que são, porém, planejadas e executadas em conformidade com opções feitas pelos entes dos três níveis ${ }^{36}$.

\subsubsection{Federalismo cooperativo brasileiro}

Para que a condução das políticas sociais possa lograr mínimo êxito, é preciso pensar em formas de transferências de recursos públicos para as áreas mais desassistidas. No Brasil, a fim de garantir o alcance do objetivo fundamental da República de reduzir a desigualdade regional, essa transferência deve obedecer ao princípio da solidariedade ${ }^{37}$.

O federalismo fiscal vai existir independentemente da estrutura de governo vigente, sem pressupor a distribuição de recursos de forma a garantir o (re)equilíbrio entre os componentes da federação. Essa é uma característica brasileira e que pode, eventualmente, ser replicada em outros sistemas. A verdade é que a forma como se dá essa divisão de recursos é que caracteriza a forma de federalismo vigente ${ }^{38}$.

Ao tratarmos de um federalismo de caráter cooperativo, como o previsto pela Constituição de 1988, temos um arranjo que permite a divisão de recursos entre os diferentes níveis da

\footnotetext{
35 "Esta unidade de atuação não significa, necessariamente, centralização. Precisamos, antes de mais nada, diferenciar centralização de homogeneização. Com a centralização há a concentração de poderes na esfera federal, debilitando os entes federados em favor do Poder Central. Já a homogeneização (unitarisierung), uniformização é baseada na cooperação, pois se trata do processo de redução das desigualdades regionais em favor de uma progressiva igualação das condições sociais de vida em todo o território nacional. A homogeneização não é imposta pela União, mas é resultado da vontade de todos os membros da Federação". BERCOVICI, 2004. p. 57.

36 "[a cooperação] consiste na concertação entre as diversas instâncias dos seus respectivos poderes em busca de objetivos de interesse comum, orientando harmônica e complementarmente seu exercício. Nessa hipótese, o tratamento uniforme se apresenta como o resultado do acordo entre as partes, mantendo todas elas seus próprios e respectivos poderes (federalismo de equilíbrio)". KUBLISCKAS. Obra citada. p. 66.

37 "A estruturação federal pressupõe transferência considerável de recursos públicos entre as regiões, fundamentada no princípio da solidariedade". BERCOVICI, 2004. p. 58.

38 "O federalismo fiscal é a espinha dorsal do sistema, em qualquer de suas versões. A maneira como são gerados e distribuídos entre as esferas de governo os recursos fiscais e parafiscais, define, em boa medida, as características próprias dos diferentes arranjos federativos. Todavia, suas feições e sua operação efetiva são, também, fortemente condicionadas pelas características de instituições políticas, especialmente os sistemas partidários e eleitorais e as organizações de interesses". TAVARES DE ALMEIDA, Maria Hermínia. Federalismo e Políticas Sociais. Disponível em: http://www.anpocs.org.br/portal/publicacoes/rbcs_00_28/rbcs28_08.htm.
} 
federação, garantindo-lhes a execução das políticas públicas, com base no princípio da solidariedade ${ }^{39}$.

Os entes federados no Brasil têm, então, as mesmas atribuições constitucionais, com responsabilidade de execução e políticas conjuntas e próprias (que estejam dentro de seu espaço de autonomia). A redução das desigualdades acaba sendo viabilizada exclusivamente por mecanismos financeiros ${ }^{40}$.

Essa talvez seja a melhor solução prática para, simultaneamente, promover a homogeneização e evitar a centralização. Com a adoção de políticas conjuntas coordenadas pelo ente central, garante-se a todos os cidadãos a prestação de um serviço de mesmo padrão, ainda que nas regiões mais desfavorecidas, por força do repasse assimétrico de recursos $^{41}$.

\subsubsection{Fortalecimento do Poder Central}

A engrenagem, porém, não funciona exatamente como previsto. Embora a Constituição tenha dotado o federalismo brasileiro dos mais diversos mecanismos de descentralização, conferindo maior autonomia aos entes subnacionais, a literatura especializada tem identificado movimento centralizador desde os anos 90. Em verdade, como lembra Marta

39 "[...] o fundamento do federalismo cooperativo, em termos fiscais, é a cooperação financeira, que se desenvolve em virtude da necessidade de solidariedade federal por meio de políticas públicas conjuntas e de compensações das disparidades regionais". BERCOVICI, 2004. p. 58/59.

"O federalismo fiscal significa a partilha dos tributos pelos diversos entes federativos, de forma a assegurar-lhes meios para atendimento de seus fins". OLIVEIRA, Regis Fernandes. Curso de Direito Financeiro. 4. ed. rev. atual. ampl. São Paulo: RT, 2011. p. 45.

40 "[...] no caso brasileiro, a autonomia e as competências dos entes federados têm grande uniformidade, fixando a Constituição regras que são de aplicação a todos os entes da federação da mesma esfera de governo. As desigualdades tendem a ser superadas por mecanismos essencialmente financeiros, com transferências assimétricas de recursos de forma a beneficiar os entes menos favorecidos". CONTI. , José Maurício. Considerações sobre o federalismo fiscal brasileiro em uma perspectiva comparada. In: CONTI, José Maurício et alli. [org.] 2010. p. 20

${ }_{41}$ "As tensões do federalismo contemporâneo, situadas basicamente entre a exigência da atuação uniformizada e harmônica de todos os entes federados e o pluralismo federal, são resolvidas em boa parte por meio da colaboração e atuação conjunta das diversas instâncias federais. A cooperação se faz necessária para que as crescentes necessidades de homogeneização não desemboquem na centralização. A virtude da cooperação é a de buscar resultados unitários e uniformizadores sem esvaziar os poderes e competências dos entes federados em relação à União, mas ressaltando a sua complementaridade. ROVIRA. Obra citada. p. 2425. 
Arretche, "a supremacia da União tem raízes sólidas no processo de construção do estadonação brasileiro. A Constituição de 1988 não foi uma exceção a essa tradição"42.

A ampla competência legislativa da União lhe permite controlar o tom das políticas nacionais, seja por influência direta nas políticas dos demais entes ${ }^{43}$ ou pelo controle na arrecadação e distribuição de recursos ${ }^{44}$. Como dispõe de competência para lançar as normas gerais de direito financeiro e tributário (art. 24, I da Constituição), deixa de criar novas modalidades de impostos e lança mão das contribuições, cuja distribuição não é obrigatória. Com isso, a União passou a concentrar a maior parte dos valores obtidos com tributos mediante o consequente desequilíbrio das contas dos demais entes - especialmente os municípios ${ }^{45}$.

Outro fator de impacto negativo nos caixas dos entes estaduais e municipais foi a criação de legislações que impuseram perdas financeiras consideráveis aos demais entes federados - a exemplo da Lei Kandir e da EC 15/96, isso sem contar as emendas de desvinculação de receitas, que têm início em 1994, sob a alcunha de Fundo Social de Emergência (FSE), muda de nome em 1997 e passa a se chamar Fundo de Estabilização Fiscal (FEF) até que, em 2000, recebe o nome mais apropriado de Desvinculação das Receitas da União $(\mathrm{DRU})^{46}$ e cessa de reduzir as transferências constitucionais obrigatórias aos Estados e Municípios.

42 ARRETCHE, Marta. Democracia, federalismo e centralização no Brasil. Rio de Janeiro: FGV; Fiocruz, 2012. p. 16.

${ }_{43}$ "A despeito de sua decisão em favor da descentralização da execução das políticas, os constituintes preservaram ampla autoridade para as iniciativas legislativas da União. [...] Em nenhuma área relevante de política pública está a União impedida de propor legislação, o que lhe confere grande capacidade de iniciativa legislativa. Portanto, na Federação brasileira, o governo federal conta com autoridade regulatória para influir decisivamente na agenda política dos governos subnacionais". ARRETCHE, Marta. 2012. p. 16.

"A União tem extensas prerrogativas legislativas, grande capacidade regulatória e significativo controle sobre a alocação de recursos. Desta forma, ao contrário do que imaginaram os constituintes e repetiram os analistas, as mudanças de 1988 são apresentadas como mais um capítulo do grande movimento de centralização estatal iniciado nos anos 1930". TAVARES DE ALMEIDA, Maria Hermínia. Prefácio. In: ARRETCHE, Marta. 2012.

45 "Como é possível termos a União que retém cerca de $63 \%$ dos recursos tributários, ficando os municípios à mingua. A estrutura federativa brasileira é uma estrutura de dominação poderosa. A União, ao longo dos anos (como o Presidente detém o controle majoritário do Congresso), passou a ter a maior fatia do bolo tributário. criou contribuições ao invés de impostos, o que fez deformar o pacto tributário". OLIVEIRA, Regis Fernandes. Introdução. In: CONTI, José Maurício. CONTI, José Maurício et alli. [org.] 2010. p. 5.

${ }_{46}$ ARRECHTE, Marta. Continuidades e descontinuidades da federação brasileira: de como 1988 facilitou 1995. In: Dados. Rio de Janeiro, vol. 52, nº 2, 2009. pp. 12 e 26. 
Embora não se trate de uma exceção aos modelos federalistas adotados mundo afora, no Brasil o constituinte não dotou os entes subnacionais de poder de veto, conseguindo evitar um engessamento sistemático de votações que possam ser de seus interesses. Segundo Marta Arretche, isso se deve à adoção de uma das mais simples regras para promoção de alterações constitucionais (emendas à constituição) existentes no mundo, que é a de 3/5 em duas sessões de cada casa ${ }^{47}$.

Isso explica a possibilidade de o governo central impor aos demais entes perdas sucessivas, de renda e de "autonomia decisória para coletar os próprios impostos, executar as próprias políticas e alocar livremente os próprios recursos orçamentários" ${ }^{\text {48 }}$. Como consequência, verifica-se uma atuação extremamente regulada, com agendas ditadas pela União, que não deixa espaço para atuações criativas e imprevisíveis - principalmente no nível municipal.

Importa dizer que, tendo a União grande controle sobre as receitas e despesas ${ }^{49}$ dos municípios, não seria de se esperar que esse nível de governo local sofra grandes dificuldades de execução das políticas públicas coordenadas pelo governo central - desde que respeitadas suas limitações estruturais.

Há, portanto, centralização da instância decisória e descentralização da execução das políticas, com controle do governo central até mesmo sobre a criação de novos tributos por parte dos entes subnacionais. A junção de medidas legislativas adotadas nos mais diversos governos, a partir do governo de Fernando Collor de Mello, com destaque para a Lei de Responsabilidade Fiscal - editada no governo de Fernando Henrique Cardoso - impôs as mais diversas perdas aos entes subnacionais ${ }^{50}$.

Como pensar, porém, em uma política coordenada pela União, de forma a atingir todos os entes subnacionais, com execução homogênea mesmo nas regiões historicamente mais

\footnotetext{
$47 \quad$ ARRETCHE, 2012. p. 18.

48 ARRETCHE, 2012. p. 19.

49 "Mais que isso, a regulação federal é também um fator explicativo central para a compreensão das prioridades de gasto dos governos locais, que também não é caótico ou aleatório. Antes, apresenta um padrão bastante claro. As políticas reguladas pelo governo têm alta prioridade e baixa desigualdade horizontal [...]". ARRETCHE, 2012. p. 21.

$50 \quad$ ARRETCHE, 2012. p 57 - "A Lei de responsabilidade fiscal, bem como um conjunto de outras leis, ampliou a extensão em que a União normatiza o modo como os Estados e Municípios executam suas próprias políticas e recolhem seus próprios impostos, afetando todos os membros da federação. Em suma, o conjunto de medidas impôs perdas a todos os tipos de minoria subnacional aos quais a literatura tem atribuído poderes de veto para impedir sua aprovação".
} 
prejudicadas pela falta de assistência e recursos em geral, quando a arrecadação se dá de forma irregular?

Se não apenas as competências legislativas, mas, igualmente, as competências executivas são distribuídas, o esquema federativo deve prever uma forma de arrecadação e compartilhamento de receitas, a fim de que haja recursos disponíveis para consecução dos objetivos previstos ${ }^{51}$.

\subsection{FEDERALISMO FISCAL}

O federalismo não tem, como já dito, uma fórmula a ser seguida, podendo variar e sofrer adaptações de acordo com as características do país que se observa. Apesar disso, é possível reconhecer notas similares entre os diferentes modelos federalistas apresentados até hoje.

A preocupação com: (i) a alocação eficiente dos recursos; (ii) o estímulo à participação política da sociedade e; (iii) as liberdades e direitos individuais são traços comuns que podem sugerir-nos a existência de federalismo em determinado Estado.

Esses fatores se conjugam e se coordenam da seguinte maneira: em um sistema de governo em que o poder não fica centralizado e distante de grande parcela da população, esta consegue ter maior participação na vida política e, como consequência, garantir maior proteção a seus direitos e suas liberdades. Como sua participação política é maior, aumenta o retorno do governo em relação às demandas dessa sociedade (quantitativa e qualitativamente). Com isso, a calibragem das políticas fica mais adequada e os recursos são alocados da maneira mais apropriada ${ }^{52}$.

Para que esse desenho funcione, pressupõe-se que o desenho institucional tenha sido definido em observância: (i) do número de níveis federativos ou instâncias de poder - a opção brasileira por três níveis autônomos é bastante diversa das dos demais países

$51 \quad$ "A decorrência direta da repartição de competências é a distribuição das fontes de recursos financeiros para equilibrar os encargos e as rendas das unidades federadas". BERCOVICI. 2004. p. 14.

52 "É um setor público com níveis decisórios tanto centralizados como descentralizados, nos quais as escolhas feitas a cada nível, relativas a provisão de serviços públicos, são determinadas em grande parte pela demanda destes serviços por parte dos residentes (e talvez de outros que aí desenvolvem suas atividades) das respectivas jurisdições.” OATES, Wallace E. Fiscal Federalism. Harcourt Brace Jovanovich, 1972. p.17 
federalistas -; (ii) da forma como essas instâncias serão representadas no nível central e; (iii) da distribuição de competências entre essas instâncias.

Esses três tópicos acabam por ser complementares e prejudiciais uns em relação aos outros na escolha do modelo de federalismo a ser adotado. Para que se possa escolher quantos níveis de governo existirão no sistema federativo, é preciso entender qual a necessidade de distribuição das competências, quer dizer, a que nível de descentralização é preciso se chegar para que haja a melhor correlação entre dimensão da política pública/número de cidadãos atendidos/taxa de externalidades negativas aceitável.

Embora a estrutura federativa seja imutável no Brasil, por força da previsão do art. 60 da Constituição, não se pode negar que as competências podem ser alteradas para um maior equilíbrio da equação acima mencionada. Como o movimento social é dinâmico, essas alterações podem ser flutuantes ou permanentes. Portanto, é preciso que haja alguma instância deliberativa que possa avaliar essas mudanças e, sendo necessário, propor readequação das competências.

Como o assunto é comum a todos os entes, parece mais apropriado que seja tratado no nível comum a todos - o central - e por representante de todos. Assim é que os representantes eleitos por cada ente federado passa a tomar assento junto ao governo central, para que possam ajudar a formular as políticas de interesse de toda a nação.

Esse movimento deve ser constante para atender à sociedade a que se destina. Muitas vezes, a descentralização pode resultar em ampliação do número de beneficiários de uma política, mas em um menor controle sobre os gastos.

O Brasil, embora tenha sido construído sob o signo da centralização - e há quem veja a continuidade perene desse perfil até a presente data - conseguiu, após a Constituição de 88, aumentar seu nível de descentralização, com transferências de algumas atribuições aos entes subnacionais, mas que não foram acompanhadas da redistribuição de receitas. Há um gap entre as competências atribuídas aos entes subnacionais e as fontes de recursos que lhes foram destinadas. 
O desenho da repartição de receitas deve ser feito de forma buscar o equilíbrio entre quem recebe e quem gasta, atendendo igualmente ao critério de descentralização da arrecadação quando o ente mais descentralizado tiver melhores condições de fiscalizar e arrecadar. Embora haja a distribuição de competência para instituição e arrecadação de tributos, no Brasil existe uma homogeneidade em relação aos tipos tributários. Essa homogeneidade acaba por refletir um agir conjunto, sempre coordenado pelo ente central, que se ocupa de verificar a adequação dos tributos aos fins perseguidos pela coletividade.

\subsubsection{Transferências voluntárias}

O tema relativo às transferências intergovernamentais envolve cessões de recursos que podem ocorrer horizontal ou verticalmente dentro da estrutura do governo. Os objetivos dessas transferências são tão diversos quanto os modelos de estrutura de governo existentes. Entre essas variedades, elas podem ser definidas em razão da norma regente, da fonte dos recursos ou de seu destino. A primeira classificação, mais frequentemente adotada pelos ordenamentos jurídicos, inclusive o brasileiro, ainda pode se subdividir em constitucional, legal e voluntária ${ }^{53}$.

Quanto ao conceito de transferências constitucional e legal, não há muito o que ser dito em relação à sua definição. O conceito de transferência voluntária pode ser encontrado no art. 25 da LRF, que a define como "a entrega de recursos correntes ou de capital a outro ente da Federação, a título de cooperação, auxílio ou assistência financeira, que não decorra de determinação constitucional, legal ou os destinados ao Sistema Único de Saúde". Verificase pela definição que existem as transferências que são voluntárias e aquelas obrigatórias, decorrentes de determinação constitucional ${ }^{54}$.

\footnotetext{
53 BARBOSA, Fernando de Holanda [coord.]. Federalismo Fiscal, Eficiência e Equidade: uma proposta de reforma tributária. Disponível em: http://www.fgv.br/professor/fholanda/Arquivo/FederalismoFiscal.pdf.

"As transferências voluntárias também não se confundem com as chamadas transferências legais, tais como as do Sistema Único de Saúde (SUS) ou como as relativas aos programas da área da educação do Fundo Nacional de Desenvolvimento da Educação (FNDE), uma vez que estas estão excluídas do conceito legal contido no art. 25, caput, da LRF. Nas transferências legais são transferências obrigatórias, em que o componente discricionariedade do órgão repassador está severamente restringido". GOMES, Emerson Cesar da Silva. A disciplina jurídica das transferências voluntárias. In: CONTI, José Maurício. SCAFF, Fernando Facury. Orçamentos Públicos e Direito Financeiro. São Paulo: RT, 2011. p. 810
} 
De acordo com a observação de Marta Arretche sobre os mecanismos de transferências adotados pelo federalismo brasileiro, a maior fonte de recursos da maioria dos municípios provém das transferências chamadas de obrigatórias ou constitucionais. Não condicionadas a nenhuma espécie de favoritismo partidário, elas permitem que o maior volume de recursos disponíveis para redistribuição alcance seu fim de redução das desigualdades regionais de acordo com critérios técnicos e não políticos. Esses influenciam as transferências voluntárias, que por seu volume, não impactam o fluxo de caixa desses governos locais 55 .

O que é importante nessa observação é que, em tese, a execução dos serviços públicos considerados essenciais não está subordinada ao jogo político-partidarista, já que o espaço para negociação é diminuto. Aliado a esse mecanismo, as transferências seguem a solidariedade federativa, por força do disposto no art. $3^{\circ}$ da Constituição, com remessa de maiores quantias para os entes menos capazes de, per si, financiarem as políticas públicas sociais.

Antes mesmo das transferências voluntárias em nível de fluxo de caixa, ainda existem as transferências condicionadas, igualmente não sujeitas a negociações, sendo dependentes, tão somente, do cumprimento das condicionantes impostas pelo governo central.

Essas transferências têm, portanto, o papel de garantir aos entes descentralizados - no Brasil, especialmente os pequenos municípios - sua autonomia, já que o ingresso de receitas (autonomia financeira) permite a execução das obrigações decorrentes de suas competências materiais de forma a manter-se um padrão mínimo entre os mais diversos entes (autonomia política).

\subsection{A INSERÇÃO DO TEMA NO DEBATE SOBRE A JUDICIALIZAÇÃO DAS POLÍTICAS PÚBLICAS NO BRASIL}

A resolução judicial dos problemas inerentes à má-prestação dos serviços públicos no Brasil, especialmente daqueles que têm maior ligação com a efetivação dos direitos sociais,

\footnotetext{
55 "as transferências constitucionais são a principal fonte de receita da esmagadora maioria dos governos locais. Transferências negociadas (voluntárias) têm um papel marginal nos cofres municipais. Logo negociações particularistas, do tipo pork barrel, não devem ter a centralidade que se lhes atribui na vida política brasileira”. ARRETCHE. 2012. p.20.
} 
tangencia esporadicamente argumentos orçamentários - é bem verdade que de forma bastante incipiente $^{56}$ - porém jamais envolve a discussão inerente à estrutura de arrecadação e gastos prevista constitucionalmente.

De que forma os entes federativos arrecadam? Quais são suas fontes de verba? Por que os Estados e Municípios recebem recursos pela via da transferência e não arrecadam diretamente? Qual a razão de ser das distribuições de competências para execução e fiscalização dos serviços públicos? Essas distribuições atendem aos próprios anseios da Constituição?

A Constituição de 88, ao alçar os mais diversos direitos à categoria de fundamentais, precisou garantir que houvesse estrutura financeira e logística para garantir seu cumprimento. Essa estrutura, no entanto, não poderia ter um desenho tão livre quanto se quisesse, uma vez que outro compromisso constitucional já o predefinia: o modelo federativo de Estado.

Estabelecida como República Federativa do Brasil $^{57}$, a estrutura de governo que confere certo grau de autonomia aos entes subnacionais, é reforçada pelo art. $60, \S 4^{\circ}$, I da Constituição, que a eleva à categoria de cláusula pétrea, portanto, inexpugnável pelo poder constituinte derivado.

Embora o art. $1^{\circ}$ da Constituição defina todos os entes como autônomos, a relação a ser estabelecida entre eles deve ter por base o princípio da lealdade federativa ${ }^{58}$, de forma a garantir que a unidade seja construída pela interação colaborativa e não com base na mútua ausência de interferência ${ }^{59}$.

56 FANTI, Fabíola. Políticas de saúde em juízo: um estudo sobre o Município de São Paulo. Dissertação de Mestrado defendida no Programa de Pós-Graduação da Faculdade de Filosofia, Letras e Ciências Humanas da Universidade de São Paulo. 2009.

57 BRASIL. Constituição da República Federativa do Brasil. Disponível em: http://www.planalto.gov.br/ccivil_03/constituicao/constituicao.htm. Art. $1^{\text {o }}$ A República Federativa do Brasil, formada pela união indissolúvel dos Estados e Municípios e do Distrito Federal, constitui-se em Estado Democrático de Direito e tem como fundamentos [...]

58 "Em primeiro lugar, a Constituição Federal de 1988 erigiu a Federação à categoria de cláusula pétrea [...] e acolheu - ainda que implicitamente - o princípio da lealdade federativa". KUBLISCKAS. Obra citada. p. 152.

59 "[...] num Estado Federal a unidade é o resultado de um processo de integração, em que a autonomia não se limita a ser um objeto passivo (garantia), mas é, essencialmente, sujeito ativo na formação desta unidade estatal (participação)". BERCOVICI. 2004. p. 10. 
A repartição de competências - ponto central do federalismo ${ }^{60}$ - surge como pressuposto da autonomia dos Estados-membros. Essa descentralização não é medida administrativa, mas sim uma atribuição de poder advinda diretamente da Constituição, que atribui a cada um dos entes federativos competências legislativas e executivas, de acordo com a pertinência do assunto a um âmbito mais restrito ou amplo de decisão ${ }^{61}$.

A Constituição de 88 dispõe de um sistema diversificado de competências, construído com espaços exclusivos e compartilhados de atuação, capaz de integrar os entes em estruturas verticais e horizontais, que se comunicam por coordenação ou delegação ${ }^{62}$.

\subsection{COMPETÊNCIAS CONSTITUCIONAIS}

A história da tradição federal demonstra que a divisão de competências é sempre o mecanismo a ser utilizado para estruturar a federação. De caráter jurídico-formal, ela tem por alicerce a autonomia dos entes, que acabam por considerar conjuntamente, quais são as partes de que dispõem para a construção do ente central ${ }^{63}$.

Nem sempre, porém, a montagem do ente central se dá por delegação dos entes subnacionais. No Brasil, cujo histórico denuncia seu centralismo, a estrutura se dá praticamente de forma inversa, principalmente com os municípios, que são um caso raro de governo local autônomo em relação aos governos estaduais.

Aqui, como descrito por Gilberto Bercovici, os entes subnacionais receberam suas competências legislativas (autonomia) e materiais (obrigações, encargos) diretamente da Constituição, não como uma simples descentralização do poder administrativo, mas, antes,

60 "[...] o Estado Federal tem, na repartição das competências, suas principais características identificadoras. Diferenciam-se as várias Federações pelas formas adotadas de atribuição aos entes federados de competências legislativas, competências para fornecimento de bens e serviços públicos e competências para arrecadar e distribuir os recursos públicos". CONTI, José Maurício. Considerações sobre o federalismo fiscal brasileiro em uma perspectiva comparada. In: CONTI, José Maurício et alli. [org.] 2010. p. 19.

61 "Não se trata de mera descentralização administrativa, mas da existência conjunta de múltiplos centros de decisão política, cada qual com a sua exclusividade em relação a determinados assuntos. A União trata dos interesses gerais, os Estados dos seus próprios interesses regionais ou locais ou daqueles que são melhor tratados se delegados ao poder local". BERCOVICI. 2004. p. 14.

62 "Estruturou-se, com efeito, um sistema complexo em que convivem competências privativas, repartidas horizontalmente, com competências concorrentes, repartidas verticalmente, abrindo-se espaço também para a participação das ordens parciais na esfera de competências próprias da ordem central, mediante delegação". ALMEIDA, Fernanda Dias Menezes de. Competências na Constituição de 1988. 5. ed. São Paulo: Atlas. 2010. p. 58.

63 BERCOVICI. 2009. 
como parte da construção de um complexo decisório multipolarizado, sonde a União é contemplada com o poder de regulação mais abrangente e os Estados e Municípios recebem autorização para tratar de assuntos cuja resolução se dá de forma mais satisfatória em âmbito local. ${ }^{64}$

\subsubsection{Competências materiais}

A distribuição das competências materiais teve de enfrentar a questão ligada aos direitos mais caros ao Estado democrático de direito, a exemplo da saúde, educação, moradia e do meio ambiente. Se de um lado surgiu o receio de relegar aos entes menores o cuidado com bens tão importantes, de outro, a atribuição exclusiva à União importaria em enormes dificuldades de realização por toda extensão territorial. Como o ente central poderia, a exemplo, gerir e fiscalizar escolas primárias e postos de saúde em todo país?

Diante dessas dificuldades, a opção do constituinte foi por atribuir aos três níveis da federação brasileira a competência para cuidar ${ }^{65}$ dos direitos inseridos no art. 23 da Constituição, de forma a garantir que houvesse sempre um responsável pelo planejamento e execução das políticas necessárias à consecução dos objetivos previstos na norma. A intenção foi conferir proteção adicional, um triplo reforço. Acontece que, a boa intenção tem revelado uma realidade perversa às contas públicas.

Embora o artigo 23 tenha atribuído uma responsabilidade coletiva a todos os entes da federação, seu parágrafo único explica que essa atuação acontecerá pela via da colaboração, estruturada por leis complementares, "tendo em vista o equilíbrio do desenvolvimento e do bem-estar em âmbito nacional",

\footnotetext{
64 "Assim, as unidades federadas recebem diretamente da Constituição Federal as suas competências, isto é, o reconhecimento de seus poderes conjugado com a atribuição de encargos. Não se trata de mera descentralização administrativa, mas da existência conjunta de múltiplos centros de decisão política, cada qual com a exclusividade em relação a determinados assuntos. A União trata dos interesses gerais, os Estados e outros entes federados (quando existem) dos seus próprios interesses regionais ou locais ou daqueles que são melhor tratados se delegados ao poder local". BERCOVICI. 2009.

65 Todos os verbos empregados nos incisos do art. 23 da Constituição remetem a essa ideia: zelar, cuidar, proteger, impedir destruição, proporcionar, proteger, preservar, fomentar, promover e combater (as causas da pobreza).

66 BRASIL. Constituição... Art. 23 [omissis] Parágrafo único. Leis complementares fixarão normas para a cooperação entre a União e os Estados, o Distrito Federal e os Municípios, tendo em vista o equilíbrio do desenvolvimento e do bem-estar em âmbito nacional. Acerca desse dispositivo, Fernanda Dias Menezes de Almeida expôs, de forma precisa e sucinta que: "É no parágrafo único do artigo 23 que a Constituição se
} 
Impossível não visualizar a intenção do constituinte, de deixar que as leis complementares, elaboradas de forma mais detida e mesmo especializada, pudessem regulamentar a forma de interação (rectius, cooperação) a ser estabelecida entre os entes para cuidado de cada um dos direitos arrolados no art. 23, com vistas a potencializar o trade off entre desenvolvimento e o bem estar.

Nesse desenvolvimento anotado pela Constituição, deve estar compreendida a ideia de desenvolvimento dos próprios entes estatais, no sentido de buscarem potencializar os recursos público, evitando-se a "dispersão de esforços que o constituinte quer ver conjugados" ${ }^{\prime 67}$.

Embora haja, então, a responsabilidade conjunta pela elaboração de políticas públicas, não importa dizer que sua execução deva ser integralmente exigível de todos os entes; do contrário, os entes menores passam a ser chamados para responder por tarefas além de suas forças e os entes maiores, igualmente, começam a ter de se preocupar com problemas pequenos e localizados, distantes de seu raio de atuação eficiente ${ }^{68}$.

O sistema deve ser racional, prevendo diferentes atribuições para cada um dos níveis federativos, sob pena de repetição ociosa de estruturas. A interpretação dessa competência como solidária em toda sua cadeia ${ }^{69}$ - do planejamento à execução e físcalização - tem trazido à lume diversas situações de conflitos administrativos, como era de se prever $^{70}$.

refere ao balizamento normativo infraconstitucional a que deverá se submeter o exercício das competências materiais comuns". ALMEIDA. Obra citada. p. 115.

$67 \quad$ ALMEIDA. Obra citada. p. 117.

68 "Estadualização é diferente de municipalização, uma vez que a capacidade de assunção das responsabilidades pelas políticas que estão sendo descentralizadas é muito diferente para estados e para municípios". ELIAS DE OLIVEIRA, Vanessa. Processo de descentralização de políticas públicas e seu impacto sobre o federalismo brasileiro. In: TAVARES, André Ramos; BUCK, Pedro [coord.]. Revista Brasileira de Estudos Constitucionais. ano 5, n. 19. julho/setembro 2011. p 201. Reforçando a percepção equivocada da interpretação vigente sobre as competências concorrentes do art. 23, Fernanda Dias Menezes de Almeida destaca que elas "estabelecerão o norte para a especificação do que compete a cada esfera política na prestação dos mesmos serviços objeto de competência comum. De fato, isto é muito importante para que, levando-se em conta as reais possibilidades administrativas e orcamentárias dos diversos parceiros, não se atribua a algum deles, em nome de uma responsabilidade solidária, tarefa que não possa cumprir". ALMEIDA. Obra citada. p. 118.

"As principais políticas sociais, como educação e saúde, foram estabelecidas como competências concorrentes, mas a perspectiva foi claramente irregular, com a União, os estados e municípios variando consideravelmente na forma como assumiram tais competências" SOARES, Márcia Miranda. Federalismo e desigualdades no Brasil atual. In: TAVARES, André Ramos; BUCK, Pedro [coord] 2011. p. 146.

70 "Como são entidades diferentes e como o objetivo da Federação é coordenar para harmonizar ordens diversas, mas não opostas, estabelece-se que 'lei complementar fixará normas para a cooperação' entre 
Esses conflitos são indesejáveis, sendo positivos ou negativos. Estes são considerados mais graves porque seus efeitos deletérios são visualizados instantaneamente: se nenhum ente presta a assistência esperada, a omissão pode importar em perda permanente de um direito por um indivíduo ou determinada coletividade. Já aqueles (positivos), são tidos por causadores de prejuízos suportáveis - uma vez que a atuação dupla ou tripla jamais deixaria perecer o direito diretamente apreciável.

Não se defende a afetação de um nível específico da federação para satisfação de um direito complexo, a exemplo da saúde e educação. A lógica perpassa a capacidade de cada ente de fazer frente às tarefas que lhes são exigidas, seja por capacidade operacional ou financeira ${ }^{71}$. Esse argumento colide com a tendência dos Tribunais brasileiros de aceitarem qualquer um dos entes no polo passivo de demandas individuais em que se veicule pedido ligado aos direitos retromencionados.

Os autores de ações judiciais que tenham por objeto o "controle de políticas públicas" podem, sob o argumento de existir solidariedade entre todos os entes, escolher livremente contra qual litigam ${ }^{72}$, impondo ao sistema federativo a indesejável sobrecarga de estruturas replicadas. Há uma confusão conceitual, que parece decorrente de um medo de ineficiência dos serviços públicos ligados aos direitos mais sensíveis, quanto à cooperação existente no federalismo brasileiro e o próprio conceito de solidariedade entre os níveis de governo.

elas. Sem que haja normas definindo o modo de atuar de cada qual e de todas, podem surgir conflitos positivos ou negativos no desenvolvimento das tarefas definidas. Ademais, o objetivo da comunidade das competências afirmadas e outorgadas a todas as entidades da Federação é exatamente o que se contém, expressamente, no texto constitucional, qual seja, 'o equilíbrio do desenvolvimento e do bem-estar em âmbito nacional'. Patenteia-se, assim, que o movimento harmonizado em unidade na diversidade e na conjugação dos interesses, para a realização de um mesmo objetivo, é que dá a tônica fundamental da comunidade das competências. Logo, para que a sua execução atenda ao objetivo constitucional, firma-se a necessidade de ter-se um conjunto de normas que especifiquem como se dará a cooperação entre as pessoas políticas". ROCHA. Obra citada. p. 251.

71 "A competência comum condensa preceitos e recomendações dirigidas à União, aos Estados, ao Distrito Federal e aos Municípios [...] São regras não exclusivas, não dotadas de privatividade e que deverão constituir objeto da preocupação comum dos quatro níveis de Governo, dentro dos recursos e das peculiaridades de cada um". HORTA. Obra citada. p. 365)

Octávio Motta Ferraz também identifica essa questão como um problema: "Desde la perspectiva de la litigación, esta responsabilidad compartida significa que un individuo o un grupo puede demandar a cualquiera de los ámbitos que considere que ha faltado a sus obligaciones. Se crea así cierta complicación, puesto que los litigantes puden elegir a qué esfera de gobierno demandar o bien hacerlo a más de una al mismo tiempo". FERRAZ, Octávio L. Motta. Brasil: desigualdades en salud, derechos y tribunales. El impacto social de la judicialización de la salud. In: YAMIN, Alicia Ely; GLOPPEN, Siri [coord]. La lucha por los derechos de la salud. Buenos Aires: Siglo Veintiuno, 2013. p. 102). 
Como demonstrado, especialmente por Bercovici ${ }^{73}$, a cooperação não importa em centralização, mas em homogeneização. O que se buscou na Constituição de 88 foi evitar soluções distintas em relação às políticas sociais pelos entes subnacionais que pudessem perpetuar a estrutura de dominação em relação a regiões mais pobres.

Até em virtude do pacto pela redução das desigualdades regionais, inserido como objetivo fundamental da República, a busca por uniformidade das políticas se deu com a concentração das competências legislativas na União ${ }^{74}$ (ARRETCHE). Com isso, foi possível a construção de soluções homogeneizantes para a saúde e para a educação.

Isso não importa dizer, porém, que todos os entes estejam sempre, em mesmo grau, vinculados à execução de cada etapa dessas políticas; do contrário, haveria indesejável sobreposição de forças e sobrecarga do sistema - sem contar a maior dificuldade de controle do uso das verbas, tema bastante sensível no Brasil ${ }^{75}$.

A solidariedade a que se alude no federalismo brasileiro diz respeito ao processo de ajuda mútua, próprio do federalismo cooperativo. Quando invocado, no contexto do exercício da competência comum para efetivação dos direitos sociais, traduz a ideia de que compete a todos os entes, solidariamente, participarem da construção da política pública que dará concretude a cada um desses direitos, a exemplo do que ocorre com o Sistema Único de Saúde.

No entanto, não há respaldo jurídico para se exigir, do ponto de vista administrativo, que todos os entes atuem na execução de toda a cadeia de realização de uma determinada política social. $\mathrm{O}$ argumento não desqualifica nem distorce a estrutura do federalismo ${ }^{76}$.

\footnotetext{
$73 \quad$ BERCOVICI. 2009.

74 "[...] parece-nos, ao contrário, que as leis complementares previstas no parágrafo único do artigo 23 não retirarão da União o comando geral no campo das competências materiais comuns, a partir do comando legislativo que lhe pertence". ALMEIDA. Obra citada. p. 117.

Recentemente, a Ministra Ideli Salvati assumiu que há roubalheira na saúde pública brasileira. Entrevista disponível em: http://noticias.terra.com.br/brasil/politica/ministra-ideli-admite-que-ha-roubalheirana-saude-brasileira,511b9a52fe1ff310VgnVCM5000009ccceb0aRCRD.html).

76 Pelo contrário, "a existência [...] de uma clara divisão de competências é condição indispensável para a produção de verdadeiras cooperações. A virtude da cooperação, neste sentido, reside essencialmente em que tais resultados unitários se produzem sem prejuízo dos poderes das instâncias autônomas, sem subtração de suas competências próprias". ROVIRA. Obra citada. p. 563.
} 
A falta de regulamentação do parágrafo único do art. 23 é apontada como a grande responsável por essa sobreposição de competências e estruturas similares ${ }^{77}$. No entanto, o problema existe mesmo em relação à saúde, que há tempos já possui um extenso regramento acerca da distribuição das atribuições de cada nível federativo.

Embora a Constituição disponha que a competência para a execução das políticas de saúde seja plenamente atribuída aos três níveis federativos, faltou-lhe a delinear a atribuição de cada um dos níveis de governo, de forma a compatibilizar o esforço com suas capacidades e evitar sobreposição de atribuições. A plenitude da competência é exercida no âmbito de atuação de cada um dos entes, sem que isso possa ser entendido como demérito ou perda de autonomia por parte dos entes subnacionais. ${ }^{78}$

Os atores institucionais deveriam passar a ter melhor compreensão acerca da responsabilidade de cada nível da federação na montagem da estrutura de atendimento à saúde brasileira. O Ministério Público e o Poder Judiciário poderiam instruir-se melhor "a respeito das responsabilidades dos entes federativos nas redes de atenção à saúde, uma vez que não tem sido muito clara essa divisão de competências e atribuições"79 para eles.

77 "For the vast majority poof public expeditures, however the constitution envisages concurrent responsibilities, to be further specified by a federal law - which so far has not been proposed [...] this lack of clarity in the assignment of spending responsibilities contributed to duplication and waste of resources in the provision of goods and services. Thus, for example, the federal government continues to be actively involved in the proposition of basic education, which in principle should be carried out by the local level, albeit with financial support by higher levels of government to the extend needed to ensure adequate minimum standards nationwide". TER-MINASSIAN, Teresa. Brazil. In: TER-MINASSIAN, Teresa [edit]. Fiscal Federalism in Theory and Practice. Washington: International Monetary Fund. 1997. p. 442.

78 "Competência plena para cuidar da saúde é um fato constitucional, porém é imperativo definir quais as atribuições dos entes para garantir conformidade à realidade socioeconômica e demográfica, com a finalidade de se evitar uma exigência incompatível com essa realidade. A competência é plena para a execução de ações e serviços de saúde que caibam nas suas capacidades técnico-financeiras, sua condição socioeconômica e demográfica. Sua competência institucional não fica diminuída ante uma menor riqueza e capacidade técnica. Esse respeito institucional ou o que temos chamado de alteridade institucional tem fundamental importância para o alcance da equidade no SUS". SANTOS, Lenir. SUS e a Lei Complementar 141 comentada. Campinas: Saberes, 2012. pp. 28/29.

79 "Não se pode perder de vista que o SUS é um sistema único num país de grandes diferenças demográficas e sócio-econômicas. Por isso é importante ter clareza dos papéis dos entes federativos nas regiões e redes de saúde onde o direito à saúde se efetiva. O SUS é um sistema interfederativo por natureza". SANTOS, Lenir. Lei 8.080/90 é regulamentada 21 anos depois: Decreto 7508/2011. Disponível em: http://blogs.bvsalud.org/ds/2011/07/16/lei-8-08090-e-regulamentada-21-anos-depois-decreto-75082011/. 


\section{A JUDICIALIZAÇÃO DOS DIREITOS SOCIAIS}

Segundo Bernardo Sorj "a grande linguagem contemporânea para reivindicação passou a ser a linguagem dos direitos. [...] A linguagem política contemporânea deixou de ser a política, passou a ser a linguagem dos direitos" ${ }^{80}$.

A busca pela satisfação dos chamados direitos sociais é, hoje, a grande bandeira das lutas sociais. Não é necessário recorrer à história: em 2013, talvez a maior manifestação popular já vista no Brasil, levou às ruas a insatisfação popular com, dentre tantos motivos, o transporte público, a educação e a saúde ${ }^{81}$.

Também conhecidos por prestacionais, os direitos sociais são tidos como a base para a formação de uma sociedade mais justa e igualitária ${ }^{82}$, razão pela qual estão intimamente ligados ao atingimento dos objetivos fundamentais da república ${ }^{83}$. Esses objetivos, indisfarçáveis compromissos assumidos pelo Constituinte jamais se puseram à sombra de outras prioridades, como se não passassem de meras promessas.

Ainda que com medidas nem sempre eficazes, decorrentes da falibilidade natural da burocracia do serviço público, o governo sempre envidou esforços para a garantia de um mínimo de satisfação dos objetivos fundamentais, por meio de adoção de políticas públicas. A definição do que seja política pública, embora sempre recorramos a conceitos jurídicos, vem das ciências políticas. Após sintetizar as ideias de autores clássicos da daquela área de conhecimento, Celina Souza ${ }^{84}$ chegou ao seguinte conceito:

80 Transcrição disponível em: www.bernardosorj.com. Acesso em: 28 de fevereiro de 2009.

81 O rol de direitos sociais está inserido no art. $6^{\circ}$ da Constituição, segundo o qual "são direitos sociais a educação, a saúde, a alimentação, o trabalho, a moradia, o lazer, a segurança, a previdência social, a proteção à maternidade e à infância, a assistência aos desamparados, na forma desta Constituição".

TELLES, Vera. Direitos Sociais. Afinal do que se trata? Belo Horizonte: UFMG. 2006. p. 171.

83 BRASIL. Constituição... Art. $3^{\circ}$ Constituem objetivos fundamentais da República Federativa do Brasil:

I - construir uma sociedade livre, justa e solidária;

II - garantir o desenvolvimento nacional;

III - erradicar a pobreza e a marginalização e reduzir as desigualdades sociais e regionais;

IV - promover o bem de todos, sem preconceitos de origem, raça, sexo, cor, idade e quaisquer outras formas de discriminação.

84 SOUZA, Celina. Estado da Arte da Pesquisa em Políticas Públicas. In: HOCHMAN, Gilberto et alli. [org.] Políticas Públicas no Brasil. Rio de Janeiro: FIOCRUZ, 2007. p. 69 
política pública com[o] o campo do conhecimento que busca, ao mesmo tempo, colocar o "governo em ação" ou analisar essa ação (variável independente) e, quando necessário, propor mudanças no rumo ou curso dessas ações (variável dependente). A formulação de políticas públicas constitui-se no estágio em que governos democráticos traduzem seus propósitos e plataformas eleitorais em programas e ações, que produzirão resultados ou mudanças no mundo real.

A aproximação da ideia de políticas públicas com os propósitos e plataformas eleitorais não desvia o foco dos direitos fundamentais. É que, em governos democráticos, submetidos à regra do direito, não há espaços para negociações e propostas que lhes subtraiam a obrigação de melhorar a realidade social mediante a garantia desses direitos ${ }^{85}$.

Portanto o Estado, mediante atuação de todos os órgãos que compõem o Poder político ${ }^{86}$, é responsável pela concretização dos direitos fundamentais (especialmente os sociais). A inserção desses direitos na Constituição atraiu a obrigatória atuação do Poder Judiciário como garantidor de seu cumprimento. No processo de autodeterminação constitucional ${ }^{87}, o$ substrato de fundamentação dos atos administrativos é deslocado da lei para a Constituição e traz o Judiciário para o protagonismo da dinâmica pública.

Por seu dever de ofício, como intérprete e guardião das normas constitucionais, o Judiciário "constituiu-se em um ator com capacidade de provocar impactos significativos no embate político, na elaboração de políticas públicas, bem como na sua execução" ${ }^{\circ 8}$.

Quando a Constituição de 88 trouxe para o ordenamento jurídico, por exemplo, o atendimento do direito à saúde por meio de um Sistema Único integrado por todos os níveis de governo da federação (art. 198), ela precisava garantir que a sua montagem fosse observada $^{89}$, independentemente da natureza que se pretendesse dar ao direito à saúde. Por

85 Como bem lembra Ada Pellegrini Grinover, há, além de tudo, a incidência do princípio da prevalência dos direitos humanos. GRINOVER, Ada Pellegrini. O Controle de políticas públicas pelo Poder Judiciário. In: GRINOVER. 2009. p. 38.

86 CANELA JR, Osvaldo. Controle Judicial de Políticas Públicas. São Paulo: Saraiva, 2011. p. 57.

87 BINENBOJN, Gustavo. Uma teoria do direito administrativo... Rio de Janeiro: Renovar, 2006. Pp. 36-7.

88 SADEK, Maria Tereza. Judiciário e Arena Pública: um olhar a partir da ciência. In: GRINOVER, Ada Pellegrini; WATANABE, Kazuo. O Controle Jurisdicional de Políticas Públicas. 2. Ed. Rio de Janeiro: Forense, 2013. P. 15.

89 "Se a Constituição estabelece a gratuidade do ensino básico, impõe a criação de um Serviço Nacional de Saúde [...] não há lugar a qualquer indagação sobre a natureza de liberdade ou social dos direitos associados àqueles deveres ou das reservas que os afectam. Independentemente do conteúdo concreto com que aquelas imposições venham a ser concebidas, elas são de realização imperativa". NOVAIS, Jorge Reis. 
conta disso, não bastava desenhar extenso rol de direitos fundamentais (arts $5^{\circ}$ e $6^{\circ}$ da Constituição); era preciso dotá-los de mecanismos de tutela ${ }^{90}$, as chamadas garantias. Somente pela previsão de garantias ${ }^{91}$ é que os direitos fundamentais podem aproximar-se da necessária efetividade, que lhes permitam incidir sobre e alterar a realidade social.

Com isso, o Judiciário tem à sua frente um amplo campo de atuação, que lhe permite velar pela adequada prestação dos serviços públicos, com atendimento aos objetivos fundamentais da República. Não se trata, portanto, apenas da proteção da integridade das normas constitucionais; para além disso, é preciso resguardar a consecução dos fins do Estado $^{92}$.

À medida que o Executivo e o Legislativo deixam de concretizar os direitos fundamentais e frustram a expectativa da população, o Judiciário cresce e tem sua legitimidade democrática robustecida por passar a atender os pleitos formulados individual ou coletivamente pelos cidadãos e demais atores sociais.

Apesar do surgimento desse novo ator, o problema que se segue é de concretização dos direitos constitucionalmente previstos. A busca pela satisfação dos direitos sociais sempre se depara com a negação da fundamentalidade desses direitos. Tidos por mera declaração de intenções, compromisso político ou, até mesmo, como uma fraude tranquilizante ${ }^{93}$, têm negada densidade normativa para figurar no rol dos direitos fundamentais. Em adição, a

Direitos Sociais. Teoria Jurídica dos Direitos Sociais enquanto Direitos Fundamentais. Coimbra: Coimbra Editora, 2010. p. 302.

90 "Do ponto de vista dos direitos, a Constituição de 1988 consagra duas mudanças fundamentais: de um lado, reconhece, além dos direitos individuais, os denominados direitos sociais, como o direito ao trabalho, à moradia, à educação, à saúde, à Previdência Social; de outro, fortalece os mecanismos de tutela de direitos. Essas inovações podem ser consideradas pontos de inflexão na história nacional, uma vez que tanto os novos direitos como os mecanismos para a sua tutela evocam a exigência de atuação estatal”. SADEK. Obra citada. P. 15.

91 "A efetividade dos direitos fundamentais ocorre pelos mecanismos de realização jurisdicional dos mesmos. A efetividade ou eficácia dos direitos fundamentais opera-se pela sua aplicabilidade real e concreta. Com isso ocorrem as possibilidades reais de concretização dos direitos fundamentais a todos os cidadãos, por meio da realização e otimização dos mesmos. As normas constitucionais são dirigidas à realidade, daí que a interpretação deve ser orientada para sua efetividade, vigência prática e material. O objetivo da garantia é a realização efetiva dos direitos fundamentais". BARACHO, José Alfredo de Oliveira. Direito Processual Constitucional - Aspectos Contemporâneos. Belo Horizonte: Forum, 2006. p. 54.

92 "O controle de constitucionalidade das políticas públicas pelo Poder Judiciário, assim, não se faz apenas sob o prisma da infringência frontal à Constituição pelos atos do Poder Público, mas também por intermédio do cotejo desses atos com os fins do Estado”. GRINOVER, Ada Pellegrini. O controle jurisdicional de políticas públicas. In: GRINOVER, Ada Pellegrini; Watanabe, Kazuo. 2013. P. 129.)

93 ABRAMOVICH, Victor; COURTIS, Christian. Los derechos sociales como derechos exigibiles. Madrid: Trotta. 2002. 
fragmentação dos direitos fundamentais ${ }^{94}$ tem por objetivo enfraquecer a justiciabilidade dos direitos sociais, tidos até o momento como direitos $\operatorname{caros}^{95}$, sob o ponto de vista financeiro.

E por serem caros, imporiam ao Estado um custo impertinente, que esgotaria as quantias destinadas a garantir os demais direitos fundamentais e manter a própria estrutura burocrática. Assim, os direitos sociais seriam garantidos apenas dentro dos parcos limites previstos pela administração, situação nomeada de reserva do possível.

É necessário promover, na linha traçada por Jorge Reis Novais, a reabilitação dogmática dos direitos sociais como direitos fundamentais, porque indispensáveis ao "processo de construção do Estado de Direito e da democracia" 96.

Ao mesmo tempo em que sustentam a criação e desenvolvimento de novos direitos, os direitos sociais representam um compromisso firmado entre o Estado e a sociedade, de maneira que seu desrespeito sinaliza um retrocesso social ${ }^{97}$ inadmissível em um Estado Democrático de Direito ${ }^{98}$.

O acesso exitoso ao Poder Judiciário se dá nas situações em que haja descumprimento do mínimo existencial ${ }^{99}$. Esse núcleo duro de direitos ostenta justiciabilidade, que nas palavras de Kazuo Watanabe ${ }^{100}$ :

[...] não é o requisito para a justiça ou para o exame de mérito da ação, e sim o requisito para o acolhimento, pelo mérito, da pretensão da tutela jurisdicional dos

94 Direitos Fundamentais a prestações, direitos de igualdade e direitos de defesa, além de direitos fundamentais de proteção, direitos fundamentais sociais e direitos fundamentais de organização e procedimento, na definição trazida por QUEIROZ, Cristina. Direitos Fundamentais Sociais... Coimbra: Coimbra Editora. 2006.

$95 \quad$ Graças à perspicaz observação de Cass Sunstein e Stephen Holmes em "The Cost of Rights. Why liberty depends on taxes", os juristas passaram a observar os chamados direitos fundamentais de liberdade sob outra ótica.

$96 \quad$ NOVAIS. 2010. p. 9.

97 Para melhor compreensão da chamada vedação do retrocesso, SARLET, Ingo Wolfgang Sarlet. Direitos Fundamentais Sociais e proibição do retrocesso: algumas notas sobre o desafio da sobrevivência dos Direitos Sociais num contexto de crise. In: Revista do Instituto de Hermenêutica Jurídica. Porto Alegre: IHJ, n. 2, p. 121-168, 2004.

$98 \quad$ QUEIROZ. Obra citada. p. 70.

99 "É esse núcleo central, esse mínimo existencial que, uma vez descumprido, justifica a intervenção do Judiciário nas políticas públicas, para corrigir seus rumos ou implementá-las". GRINOVER, 2009. p. 43.

100 WATANABE, Kazuo. Controle Jurisdicional das Políticas Públicas - Mínimo existencial e demais direitos fundamentais imediatamente judicializáveis. In: GRINOVER, Ada Pellegrini; WATANABE, Kazuo [coord.]. O Controle Jurisdicional de Políticas Públicas. Rio de Janeiro: Forense, 2011. p. 216. 
direitos fundamentais sociais, ou seja, a efetiva existência do direito fundamental social tutelável jurisdicionalmente.

Kazuo Watanabe, com respaldo da jurisprudência do STJ e do STF sobre a matéria, anota que o fornecimento dessas condições, inseridas na ideia de mínimo existencial, não se submete a qualquer argumento de restrição orçamentária.

Isso não significa que toda omissão do Poder Público quanto ao atendimento de direitos sociais dá ensejo a um provimento de mérito numa ação judicial que visa ao controle de política pública. Para Cristina Queiroz, a concretização dos direitos sociais pode ser diferenciada entre as espécies, a depender do conteúdo normativo conferido pela Constituição. Quando o texto constitucional "se limita a enunciar o direito e a impor ao legislador a promoção das condições que o tornem efectivo"101, seu âmbito de aplicação atinge o grau máximo.

A par dessas considerações, impossível sustentar a tese de viabilidade de implantação imediata de todos os direitos sociais em seu grau máximo de satisfação. O que se quer dizer é que, progressivamente, o Poder Público é obrigado proporcionar à população o acesso a esses direitos. Para os não atendidos, o cidadão passa a valer-se do Poder Judiciário em busca de uma ordem em face do Executivo.

Na pendência da elaboração de normas e políticas públicas que lhes tragam à vida, que delimitem seu atendimento, que disponham sobre suas respectivas fontes de custeio, os direitos correm o risco de se desbotar, se desintegrar ${ }^{102}$. A resposta para essa espera está, justamente, no modelo padrão de democracia em que a concretização de um direito depende da vontade política de outro ${ }^{103}$, o eleito.

A ideia é conseguir ampliar a ideia de participação da sociedade na execução das leis orçamentárias, extravasando o modelo de orçamento participativo. Após a aprovação das

\footnotetext{
$101 \quad$ QUEIROZ. Obra citada. p. 70.

102 "Nesse sentido é que esta Casa de Justiça imprimiu concretização a direitos fundamentais, cuja mora legislativa transformou suas eficácias limitadas em direitos desintegrados". BRASIL. Supremo Tribunal Federal. RE 566509, Relator(a): Min. AYRES BRITTO, julgado em 11/10/2011, publicado em DJe-201 DIVULG 18/10/2011 PUBLIC 19/10/2011.

103 "Cuida-se, antes de tudo, para preenchimento do conceito, de uma decisão política. O Estado é quem vai dizer, para usar o verbo vicário, no texto constitucional e nas leis posteriores, quais as necessidades que vai encampar como públicas". OLIVEIRA. Obra citada. p. 73.
} 
leis orçamentárias, o Judiciário poderia atuar no controle da realização do plano de trabalho apresentado bem como de suas respectivas dotações.

A abertura para sua atuação está contida na superação do conceito de legalidade inserido nos artigos 75, I e 77, da Lei 4.320/61 ${ }^{104}$. Como já demonstrado, o paradigma da legalidade sucumbiu à pujança dos preceitos constitucionais. Portanto, é perfeitamente sustentável a ideia de que os atos de execução do orçamento são controláveis por violação direta às normas fundamentais ou descumprimento da prevalência dos direitos fundamentais.

Em virtude da dificuldade de muitos juristas em enfrentar a complexidade da ferramenta orçamentária, por vezes a Administração se vê prostrada diante de uma decisão judicial não razoável, em decorrência dos profundos impactos financeiros causados. Esses impactos são ainda maiores quando se trata de decisão proferida com base em cognição sumária típica da apreciação de pedidos de tutela de urgência ${ }^{105}$. Equívocos dessa natureza podem ser atribuídos à impropriedade ou talvez incompletude dos instrumentos processuais disponibilizados aos juízes.

E uma das principais questões que se apresentam diz respeito ao polo passivo desse tipo de ação judicial. Para a linha seguida nesse trabalho, sempre que um direito for judicializado, seja ele parte do mínimo existencial ou não, deverá sê-lo exigido primeiramente em face do ente diretamente responsável pela sua garantia e, somente em caso de absoluta inexistência de verba disponível, haverá transmissão da obrigação para o ente federado mais abrangente (Município-Estado; Estado-União).

\subsection{PROCESSOS JUDICIAIS E A QUESTÃO ORÇAMENTÁRIA}

O tema orçamentário acaba trazendo a discussão acerca da falta de discricionariedade do administrador no emprego das receitas públicas, para consecução dos objetivos a que se

104 BRASIL. Lei n. 4320, de 17 de março de 1964. Artigo 75. O controle da execução orçamentária compreenderá: I - a legalidade dos atos de que resultem a arrecadação da receita ou a realização da despesa, o nascimento ou a extinção de direitos e obrigações.

Artigo 77. A verificação da legalidade dos atos de execução orçamentária será prévia, concomitante e subsequente.

105 "Nas ações sumárias cautelares e não cautelares [...] a cognição é sumária ou superficial. Essa modalidade de cognição é, também, a que o juiz realiza por ocasião das medidas liminares em geral, inclusive na antecipação da tutela prevista no art. 273 do Código de Processo Civil". WATANABE, Kazuo.

Cognição no Processo Civil. São Paulo: Saraiva. 2012, p. 127. 
propôs junto ao seu eleitorado. No Brasil pouco se permite ao gestor a utilização criativa de recursos públicos, já que grande parte do orçamento fica engessado por força das vinculações constitucionais.

Essa discussão, embora válida, encobre a anterioridade e, porque não dizer, superioridade de outras normas constitucionais, que dispõem sobre os já mencionados objetivos fundamentais da república e os direitos fundamentais ${ }^{106}$.

A execução das políticas públicas sociais, como afirmado anteriormente, depende de um modelo racional de distribuição de competências e recursos financeiros aos entes federados. Disso decorre a compreensão de que o orçamento é tema inseparável da discussão acerca do controle das políticas públicas e, logo, das formas de cumprimento dos objetivos fundamentais da república ${ }^{107}$.

\subsubsection{A constitucionalização do sistema orçamentário brasileiro}

A Constituição de 1988 prestigiou o sistema orçamentário, alçando-o a matéria de ordem constitucional, com detalhes descritos nos artigos 165 a 169. Sua construção fundamental foi subdividida em três diferentes normas legais, complementares e com distintos prazos de vigência.

Salvo concessões feitas a leis complementares vindouras, a Constituição cuidou de dispor das minúcias do contexto de elaboração do orçamento público, prevendo inclusive prazos de encaminhamento dos projetos de lei (previsão feita nos Atos de Disposição Constitucional Transitórios).

\footnotetext{
106 "Ocorre que as limitações aos gastos públicos também podem ser materiais, pois o uso de recursos públicos deve se dar de forma a permitir que os objetivos estabelecidos no art. $3^{\circ}$ da Constituição sejam alcançados. Para tanto é imprescindível que sejam realizados gastos públicos em direitos fundamentais sociais [...] Logo, os gastos públicos não permitem que o legislador, e muito menos o administrador, realizem gastos de acordo com suas livres consciências, de forma desvinculada aos objetivos impostos pela Carta, especialmente em seu art. 30". SCAFF, Fernando Facury. Reserva do possível, mínimo existencial e direitos humanos. In: PIRES, Adilson Rodrigues. TORRES, Heleno Taveira (org.). Princípios de direito financeiro e tributário. Estudos em homenagem ao Professor Ricardo Lobo Torres. Rio de janeiro: Renovar, 2006. p. 125 .

107 "O orçamento é o principal instrumento de realização de política públicas. Assim, a finalidade do Estado, ao obter recursos, para em seguida gastá-los sob a forma de obras, prestação de serviços, ou qualquer outra política pública, é a de realizar os objetivos fundamentais da Constituição Federal". RIBEIRO, Maria de Fátima. Efetivação de Políticas públicas: uma questão orçamentária. In: CONTI, José Maurício; SCAFF, Fernando Facury. 2011. p. 1091.
} 
O plano plurianual, mecanismo de definição do planejamento das atividades governamentais $^{108}$, funciona como uma projeção dinâmica ${ }^{109}$ dos investimentos, inversões financeiras e transferências de capital, de maneira a demonstrar quais seriam os setores privilegiados pela política de governo daquele que foi eleito - o texto legal comporta emendas, remanejamentos e outra alterações pelo legislativo, mas deve refletir a prospecção traçada pelo líder do executivo.

Claro que o orçamento não se preocupa apenas com as despesas; afinal, para cogitá-las é preciso, primeiramente, pensar em suas respectivas fontes de custeio, ou seja, nas receitas que poderão lhe fazer frente. Entretanto, os mecanismos de arrecadação não serão objeto de nosso olhar.

Retomando, o Plano Plurianual consubstancia as despesas relativas a programas de duração continuada. É regulamentado pelo Decreto 2.829, de 29 de outubro de 1998 e é responsável pela linha mestra do governo pelo período de quatro anos.

$\mathrm{O}$ artigo 165, parágrafo $2^{\circ}$, da Constituição, apresenta-nos a lei de diretrizes orçamentárias, segundo o qual "compreenderá as metas e prioridades da administração pública federal, incluindo as despesas de capital para o exercício financeiro subsequente, $[\mathrm{e}]$ orientará a elaboração da lei orçamentária anual, disporá sobre as alterações na legislação tributária e estabelecerá a política de aplicação das agências financeiras oficiais de fomento".

Trata-se de uma lei de eficácia temporal limitada ${ }^{110}$, que serve de guia para elaboração da Lei Orçamentária Anual, dispondo, como dito, das despesas de capital para o exercício financeiro subsequente, em obediência à consolidação promovida no Plano Plurianual.

Referida lei serve, ainda, para limitar as obrigações que gerem dispêndio de verbas, estabelecer normas relativas ao "controle de custos e à avaliação dos resultados dos programas financiados com recursos do orçamento" ${ }^{111}$, além de estabelecer "condições e

\footnotetext{
108 OLIVEIRA. 2011. p. 386.

109 Diz-se dinâmica, pois, havendo alteração palpável da conjuntura econômica do ente governamental, não existem empecilhos a que haja alteração do Plano Plurianual.

110 BRASIL. Supremo Tribunal Federal. ADI n ${ }^{\circ}$ 612-RJ. Rel. Min. Celso de Mello. DJ 19.09.1997.

111 BRASIL. Lei Complementar n. 101, de 4 de maio de 2000, Art. $4^{\circ}$, I, e.
} 
exigências para transferências de recursos a entidades públicas e privadas" ${ }^{112}$. Por determinação trazida pela Lei Complementar 101/2000, a Lei de Diretrizes deve apresentar, ainda, o anexo de metas fiscais.

Em complemento à tríade, a Lei Orçamentária Anual, mais simplificada, direta, objetiva e mais destinada à efetiva implementação das ideias carreadas nas lei anteriores. Por imposição do $\S 8^{\circ}$, do art. 165 , da Constituição, a lei orçamentária deve obedecer ao princípio da exclusividade, ostentando apenas matéria orçamentária.

Essa faceta proeminente das leis orçamentárias decorre da adoção, pelo Brasil, do modelo conhecido por orçamento-programa, de acordo com o qual devem ser consideradas as "necessidades reais da administração e da população, [assim como] os objetivos econômicos-sociais a atingir com sua execução" ${ }^{113}$.

Nota-se, por esse viés, a boa vontade do sistema orçamentário brasileiro, "que pretende modificar deonticamente as condutas dos agentes públicos que regem as finanças estatais" 114 .

Fato é que as balizas tradicionais não funcionaram; o uso indiscriminado da verba pública trouxe, nos últimos anos, tentativas quase vãs de se deter a corrupção e os desvios patológicos de recursos. Lei do Colarinho Branco, Lei de Improbidade Administrativa, Lei de Responsabilidade Fiscal, Lei dos Crimes de Lavagem de Dinheiro (não direcionada apenas aos atentados contra o erário), são algumas dessas promessas de melhorias, "por decreto", da postura dos agentes públicos ${ }^{115}$.

Em um país de dimensões territoriais, com índice de desenvolvimento humano sempre questionável, tomou-se por hábito conduzir a discussão em torno da correta utilização das

\footnotetext{
$112 \quad$ BRASIL. Lei Complementar $101 \ldots$ Art. $4^{\circ}$, I, f.

113 SILVA, José Afonso da. Orçamento-programa no Brasil. São Paulo: Editora Revista dos Tribunais, 1973, p. 1 e 2.

114 CHRISTOPOUlOS, Basile. Despesa Pública. Estrutura, função e controle judicial. Maceió: UFAL. 2011. p. 41.

115 "[...] A crise do modelo de representação e o crescente distanciamento da burocracia em relação à esfera pública, como apontou Habermas, acarretam uma crise de legitimidade do modelo de democracia representativa e um gradativo avanço da corrupção, visto que os elementos de responsabilização política se tornaram ineficientes em face da pouca densidade dos partidos junto ao eleitorado". FILGUEIRAS, Fernando. Corrupção, democracia e legitimidade. Belo Horizonte: UFMG. 2008. p. 165.
} 
verbas públicas, com enfoque no atendimento dos chamados direitos fundamentais e sociais - aqui traduzidos para necessidades públicas. Tanto é que, como tema recorrente nas construções orçamentárias, as chamadas "verbas carimbadas" aparecem como salvadoras ou intransponíveis obstáculos - a depender do interesse que se sustente.

\subsubsection{As necessidades públicas}

O atendimento dessas necessidades, como sói ser, é realizado pelo Estado por intermédio dos chamados gastos públicos ${ }^{116}$. Por essa razão, fica fácil identificar a pertinência do assunto orçamentário aos chamados direitos fundamentais e sociais.

A definição do orçamento passa, como dito, por um esquema tripartido de montagem de um grande fluxo de caixa, por meio do qual o Estado consegue identificar quanto poderá gastar em cada área que considere prioritária.

Ocorre que alguns temas foram, desde a elaboração da Constituição de 88, definidos como necessidades públicas a serem atendidas, excluindo a margem de discricionariedade do administrador, tal como ocorre na saúde e na educação. Essas despesas pré-fixadas foram apelidadas de verbas carimbadas, ou seja, com destino certo e em montante mínimo fixo.

Atendida a aplicação dos recursos mínimos exigidos pela Constituição, o gestor não pode ser responsabilizado por inobservância dos preceitos constitucionais mandatórios. Assim, a princípio, as verbas carimbadas acabam por se revelar piso e teto do gasto com a área tida por prioritária, talvez por faltar o sentimento de que "para além das garantias formais inscritas na lei, os direitos estruturam uma linguagem pública que baliza os critérios pelos quais os dramas da existência são problematizados em suas exigências de equidade e justiça" $^{117}$.

As leis que compõem a integralidade do processo orçamentário constituem o centro do planejamento de qualquer política pública $^{118}$. O problema está, pois, na interpretação

\footnotetext{
116 "Porque toda ação estatal pressupõe um gasto, mesmo que seja apenas com a manutenção do aparelho estatal por trás daquela ação". CHRISTOPOULOS. Obra citada. p. 150.

117 TELLES. Obra citada. p. 178.

118 "[...] o orçamento é o palco no qual devem estar explicitadas as políticas públicas de um Estado em um determinado momento. E, nele, o Estado, conjuntamente as funções executivas e legislativa devem se
} 
acerca da natureza jurídica do orçamento, na negação deste enquanto responsável pelo nível de satisfação dos direitos sociais ${ }^{119}$.

É preciso que se reconheça que o orçamento não tem apenas caráter político, uma vez que dele dependem o planejamento e a execução de todas as políticas públicas voltadas ao atingimento dos objetivos fundamentais da República. Se os direitos à saúde e à educação, por exemplo, são indispensáveis à concretização da cidadania, como relegar ao mandatário liberdade absoluta na construção e aplicação do orçamento? O debate acerca da reserva do possível, por exemplo, somente é viável tendo por pano de fundo a situação do ente federado. Apenas após conhecidas suas deficiências admite-se a discussão acerca da programação e da execução orçamentária ${ }^{120}$.

Importa dizer, para falar no controle judicial de políticas públicas é preciso deixar para trás o medo de se conhecer as peças orçamentárias ${ }^{121}$, pois somente a compreensão acerca do volume de arrecadação e da natureza das despesas públicas nos autoriza a dizer se os gastos atendem ou não aos comandos constitucionais concernentes aos direitos fundamentais $^{122}$.

fazer presente, via processo orçamentário, desde a elaboração do plano plurianual, passando pela lei de diretrizes orçamentárias, e com a lei orçamentária anual”. RIBEIRO. Obra citada. p. 1093).

119 "Nesse ponto, é de se repensar a ideia difundida de que o Orçamento é lei meramente formal, porque não cria direitos subjetivos, e, como consequência não gera deveres para o Poder Público, mas faculdades de realização das políticas anunciadas. A ordem de despesas orçamentárias [...] pode criar e afetar direitos subjetivos, sobretudo, considerando o constante conflito entre a concretização de direitos sociais e a reserva do possível". MACHADO, Raquel Cavalcanti Ramos. A mudança do paradigma orçamentário... In: CONTI, José Maurício; SCAFF, Fernando Facury. 2011. p. 1061.

120 "Na escolha das ações de governo, o ato que seria meramente político ganha juridicidade na medida em que há valores constitucionais a serem preservados. Ou seja, as políticas públicas começam a ser tratadas na própria Constituição, segundo a qual saúde e educação são pautas prioritárias. Dessa forma, ainda que se possa dizer que um prefeito tem liberdade para escolher fazer os mais diversos programas culturais, como promoção de shows, talvez essa liberdade não seja tão ampla quando se imagina um município paupérrimo cujas normas educacionais e do sistema de saúde são minimamente cumpridas. Da mesma forma, ainda que tenha liberdade para escolher realizar as mais diversas obras, o grau de suntuosidade também seria passível de controle". MACHADO. Obra citada. p. 1061)

121 "El desarollo de um derecho constitucional presupuestario, la sujeción de la decisión presupuestaria a diversos princípios jurídicos como el de la reserva de ley o el de razonabilidad, la existência de uma cuestion presupuestaria em cuanto eventual razón alegada por el Estado para justificar la no realización de políticas públicas com relación a los derechos humanos, son todos factores que conducen a considerar la sujeción de las decisiones presupuestarias al control judicial de constitucionalidad. El principio básico es claro: el presupuesto no es ni puede ser ajeno al conocimiento de los jueces". CORTI, Horacio Guillermo. Derecho Constitucional Presupuestario. Buenos Aires: AbeledoPerrot, 2011. p. 881.

122 “[...] numa visão holística da realidade, é preciso costurar receitas e despesas, e admitir o controle destas, a fim de que se concretize o Estado Social”. MACHADO. Obra citada. p. 1063. 
As decisões do STF, que refletem no entendimento manifestado pelos demais tribunais acerca da matéria, insistem em colocar a questão orçamentária como secundária, inferior ao debate acerca dos direitos fundamentais, quando todas essas têm reflexos orçamentários senão diretos, indiretos ${ }^{123}$.

Os Tribunais estão diariamente lidando com os orçamentos dos entes federados, alterandoos de forma impensada e, no limite, irresponsável, mas, quando são chamados ao conhecimento da verdadeira estrutura orçamentária alegam tratar-se de questão secundária não imponível à efetivação dos direitos fundamentais. Se toca os direitos fundamentais ${ }^{124} \mathrm{e}$ os objetivos fundamentais da República, a questão é jurídica e assim deve ser tratada ${ }^{125}$.

O cumprimento desses compromissos é tarefa prioritária e deve se sobrepor a gastos secundários ou desnecessários, sem que isso revele uma perversão dos princípios constitucionais da administração ${ }^{126}$. Cada vez mais, os administradores são submetidos a regras de responsabilidade, com reflexos nas esferas administrativa, civil e penal, caso não atentem para o uso adequado e probo das verbas públicas postas sob sua gestão. Com as constantes investidas do Poder Judiciário sobre os orçamentos, fica cada mais difícil cumprir com as fórmulas restritivas inseridas, especialmente, na Lei de Responsabilidade Fiscal $^{127}$.

123 “[...] los diversos casos judiciales sobre el derecho a la salud muestran decisiones judiciales que, por ejemplo, al ordenar el suministro de medicamentos, tienen efectos presupuestarios indirectos". CORTI. 2011 p. 881 .

"El principio de razonabilidad, entendido como principio financeiro substantivo, esablece lo siguiente: la actividad financiera pública debe ser um médio adecuado para asegurar el ejercicio habitual de los derechos fundamentales". CORTI. 2011. p. 697.

125 "Dicho de forma general: todas las decisiones financieras son susceptibles de ser conocidas por los jueces y de ser objeto del control judicial de constitucionalidad. Y junto a las razones específicas referidas a la actividad presupuestaria, que es la condición básica de realización de la actividad política y, por ende, com suficiente capacidad para formar parte de procesos causales que culminen em la lesión de derechos fundamentales, hay que admitir que un enfoque que pretenda sujetar todo el accionar del Estado al derecho no puede acceptar la doctrina de las cuestiones no judiciables o de las cuestiones políticas”. CORTI. 2011. p. 882.

126 Art. 37. A administração pública direta e indireta de qualquer dos Poderes da União, dos Estados, do Distrito Federal e dos Municípios obedecerá aos princípios de legalidade, impessoalidade, moralidade, publicidade e eficiência e, também, ao seguinte [...]. BRASIL. Constituição...

127 "Considerando-se a boa-fé do gestor condenado a cumprir uma determinação judicial para o pagamento de fármaco ou terapêutica, devemos analisar os limites legais orçamentários para o cumprimento da sentença. Quero deixar claro, no entanto, que não defendo que a análise econômica do direito ou de questões de ordem administrativa venham a se sobrepor à garantia do direito constitucional à vida e à saúde. O que é preocupante é o absoluto desconhecimento ou, pior, a absoluta desconsideração, pelo Poder Judiciário, dos limites legais impostos ao gestor pela legislação orçamentária e constitucional, com suas implicações administrativas e inclusive penais e patrimoniais para o gestor, sem deixar de citar os impactos possíveis de restrição dos seus direitos políticos, todos ligados à execução do orçamento público de determinada dotação orçamentária. A dotação da saúde não foge a essa regra”. BLIACHERIENE, Ana Carla; 
Essa despreocupação do Poder Judiciário com as normas orçamentárias é potencialmente lesiva às contas públicas, podendo conduzi-las a um patamar de desajuste estrutural. Nesse cenário, o descontrole abre espaço para maior corrupção e consequente redução das receitas públicas disponíveis para investimento nos setores prioritários, tais como saúde e educação. A preocupação com o cumprimento das promessas constitucionais deve se dar com a observância das normas que estruturam as despesas públicas ${ }^{128}$.

Em outras palavras, se as leis orçamentárias devem servir para que o Estado consiga atingir seus objetivos fundamentais ${ }^{129}$, sua desestruturação somente servirá como empecilho a essa tarefa. A atuação do Poder Judiciário nesse ponto é perniciosa porque mina a base de legitimidade de seu discurso.

A considerar: (i) que a prioridade imposta pela Constituição ao estado brasileiro é o cumprimento dos objetivos fundamentais da República e a satisfação dos direitos fundamentais; (ii) que o instrumento para concretização dessa prioridade são as chamadas políticas públicas; (iii) que nenhuma política pública pode ser executada sem que tenha sido fruto de um planejamento orçamentário ${ }^{130} \mathrm{e}$; (iv) que o orçamento serve como redutor das arbitrariedades e garante a legalidade e constitucionalidade das escolhas feitas pelos gestores públicos ${ }^{131}$, não é possível que se admita a atuação do Poder Judiciário que não observe, declaradamente, a estrutura orçamentária dos entes federados.

MENDES, Guilherme Adolfo dos Santos. Lei de Responsabilidade Fiscal e os limites da vinculação e da discricionariedade na execução da dotação orçamentária: o impacto das liminares judiciais relativas à saúde para o orçamento dos municípios. In: BLIACHERIENE, Ana Carla; SANTOS, José Sebastião [org.] Direito à vida e à saúde. Impactos orçamentário e judicial. São Paulo: Atlas, 2010. p. 22.

128 "A frase preocupante que já tivemos a oportunidade de ouvir de juízes, em situações distintas ao tratar do tema, 'dane-se o orçamento', demonstra o rumo de subdesenvolvimento e falta de seriedade que o Judiciário pode imprimir às contas públicas, sem as devidas alterações estruturais, se houver uma imposição de despesas em grande escala no setor da saúde ou qualquer outro setor que contenha demandas sociais reprimidas". BLIACHERIENE. Obra citada. p. 25.

"Ressalte-se que qualquer plano ou programa de ação estatal deve observar, em última instância, a consecução dos objetivos fundamentais da República Federativa do Brasil, expressamente insculpidos no art. $3^{\text {o }}$ de nossa Constituição Federal, de modo que, também as leis orçamentárias devem servir de instrumental ao atendimento destes supremos desígnios”. ASSONI FILHO, Sérgio. Controle de Constitucionalidade da Lei Orçamentária. In: CONTI, José Maurício; SCAFF, Fernando Facury. 2011. p. 24.

130 "La finalidad de la actividad financiera pública (o de la Hacienda Pública, de las Finanzas Públicas, de la renta pública, del Tesoro, del Derecho Financiero o, en fin, del conjunto sistemático de las técnicas jurídico-financieras) consiste en otogarle efectividad a las instituciones constitucionales". LAPATZA, José Juan Ferreiro. Curso de derecho financiero español. Instituciones. 25. ed. Madrid: Marcial Pons, 2006. p. 41 .

131 Nesse sentido, as leis orçamentárias se prestam à coibição de arbitrariedades na gestão da coisa pública, na medida em que impedem um distanciamento entre a atuação prática dos agentes políticos e o 
Não que o Poder Judiciário possa, arbitraria e livremente, alocar recursos públicos nos programas que entenda necessária. A questão passa pela necessidade de conhecimento das peças orçamentárias para que possa, com maior correção, atuar no controle das políticas públicas, já que, inegavelmente, essas decisões acabam por gerar reflexos no orçamento dos entes federados ${ }^{132}$.

Como anotado por Basile Christopoulos ${ }^{133}$, embora a atuação do Poder Judiciário pareça mínima no cenário federal, ela é quase tão impactante quanto a do Poder Legislativo, que está inserido no processo de formulação das peças orçamentárias. De todo o orçamento da União, o Poder Judiciário é responsável pela alteração de 1,82\% da alocação originária das receitas, enquanto o Poder Legislativo, participante do processo de deliberação das leis orçamentárias, responde por apenas $2,96 \%$ dessas mudanças.

Portanto, seja pela magnitude de sua atuação ou por seu dever de ofício de fundamentar suas decisões (art. 93, IX, da Constituição), o Poder Judiciário não pode se furtar ao conhecimento e consideração da matéria orçamentária nos processos de controle de políticas públicas.

O argumento do Judiciário de que não pode ou não deve se imiscuir no orçamento é falacioso, pois sempre que controla a execução de uma política pública ele está, diretamente, investindo contra a programação do Executivo. E se há interferência no orçamento, ela deve ser minimamente justificada e explicada ${ }^{134}$.

plano de trabalho fixado em prospecto nas leis orçamentárias aprovadas, isto é, as leis orçamentárias podem evidenciar a ilegalidade ou mesmo a inconstitucionalidade de uma decisão governamental, a qual não poderá ser legitimada pela mera alegação de exercício de um suposto juízo de conveniência e oportunidade. ASSONI FILHO. Obra citada. p. 25.

132 "Indudablemente, no se trata en el caso de asignar recursos presupuestarios de forma discrecional sino, de forma más básica, de si los actores tienen um derecho y de si el es judicialmente exigible, para luego determinar la forma em que debe ser protegido, decisión que puede tener efectos presupuestarios". CORTI. 2011. p. 887.

133 CHRISTOPOULOS. Obra citada. p. 115.

134 "Nos demais casos em que determina a prestação de serviços de saúde ou educacionais ao Poder Executivo, o mesmo controle [orçamentário] é feito, apesar de não ser anunciado. Aqui, a fundamentação das decisões é falha. Não há como gerar despesas sem análise e consideração expressa do Orçamento. Via de regra, diante de pleitos judiciais para implementação de políticas públicas, o Poder Executivo invoca a reserva do possível e informa que não dispõe de verba para atender à demanda formulada. O Poder Judiciário atentando para a essencialidade do bem, defere-o ou não, e quanto à reserva do possível, limita-se a afirmar que o Poder Público não provou não dispor de verba, ou, em outros casos, a questão é ignorada apesar de sua invocação. Na verdade, em vez de agir assim, o Poder Judiciário pode decidir no mesmo sentido, mas 
A dificuldade seria conseguir explicar grande parte das decisões proferidas em sede de controle de políticas públicas perante os princípios constitucionais da economicidade e eficiência. As decisões de gastos por parte do Executivo se submetem a esses princípios, logo, o mesmo se aplica ao Judiciário quando autoriza ou ordena uma despesa.

Aliados aos princípios, já consagrados, da legalidade e da moralidade, os princípios da economicidade e da eficiência passam a pautar o agir do administrador de forma a exigirlhe um atuar ótimo, que observe os preceitos legais e consiga produzir, em tempo oportuno, uma decisão importe em menores custos ao erário e favoreça o maior número de cidadãos. É a relação custo/benefício.

Como justificar decisões que impõem ao Administrador a compra de medicamentos que poderiam ser prestados por outro ente? Como fundamentar uma decisão que ordena um município a dispender verbas para custeio de prótese de cidadão que nele não reside?

Em coerência com os princípios da economicidade e da eficiência, o SUS foi construído de forma a privilegiar a atuação prioritária, preferencial, de cada ente em determinado objeto. A sombra da União que se nota em todo o sistema deriva, como dito, da necessidade de homogeneização, como garantia do cumprimento do objetivo fundamental da República de redução das desigualdades regionais.

Assim também se observa na concretização do direito à educação. Todos os entes são, solidariamente, responsáveis por colocar em andamento um plano de educação, que dê conta de abranger desde a educação infantil até a educação superior. No entanto, a execução acaba sendo, por força do disposto no art. 211 da Constituição, desmembrada entre os entes de forma que cada um absorva uma parcela adequada à proporção de sua capacidade administrativa.

O que se defende é que o exercício das funções do Poder Judiciário no processo de controle de políticas públicas observe a estrutura administrativa prescrita constitucionalmente ao Executivo, como forma de preservar a racionalidade do sistema e

legitimando sua decisão por meio de uma análise do Orçamento, ainda que breve, ponderando o elenco de gastos". MACHADO. Obra citada. p. 1059. 
atingir um ponto ótimo de alocação de recursos públicos. A premissa, pois, é de que o Judiciário hoje funciona como dreno de verbas públicas sem conseguir gerar justiça social, sem conseguir incluir os excluídos e, como destacado, sem atinar para os princípios da economicidade e da eficiência.

\subsubsection{Os princípios da eficiência e da economicidade}

Não há dúvidas de que a Administração deve agir de forma a conferir efetividade aos direitos fundamentais. $\mathrm{O}$ atendimento das necessidades públicas, reveladas pelo rol desses direitos, deve ser prioridade no atuar dos mandatários, sempre guiado pelos princípios destacados no artigo 37 da Constituição.

O agir eficiente não está vinculado a razões puramente financeiras e econômicas, mas, antes, está destinado à otimização da realização dos direitos fundamentais, pois quanto mais cidadãos forem atendidos com menor dispêndio de recursos, maiores são as chances de se conseguir erradicar a pobreza e a marginalização (art. $3^{\circ}$, III da Constituição). Prova de que não se defende a predominância da economia sobre o direito é essa defesa do papel dos mecanismos financeiros em prol da satisfação dos direitos fundamentais.

Mas, para que essa estrutura benéfica possa operar adequadamente, os responsáveis pelo manejo das verbas públicas devem estar familiarizados com a matéria. Os Poderes Executivo e Legislativo têm em seus quadros técnicos habilitados que participam das decisões orçamentárias. Já o Poder Judiciário, pelo formato de seu espaço decisório, dedicado apenas aos bacharéis em direito, acaba por tratar do tema de maneira senão equivocada, incompleta. Por isso, o Judiciário passa a gerar uma externalidade negativa, ao desestruturar os orçamentos dos entes federados sem assumir a responsabilidade por sua ação $^{135}$.

135 "A principal característica da externalidade negativa está associada ao fato de que a ação de um agente gera consequências indesejadas a outros, mas, mais do que isso, o mecanismo clássico de mercado não consegue precificar adequadamente tais malefícios, pois o agente gerador não assume todos os custos decorrentes de sua ação [...] SAKURAI, Sergio Naruhiko et ali. Emenda constitucional $n^{\circ}$ 29/2000: influência sobre a execução orçamentária dos Estados e municípios brasileiros em saúde. In: BLIACHERIENE, Ana Carla; SANTOS, José Sebastião [org.] 2010. p. 2. No mesmo sentido: "Nesse sentido, uma decisão judicial que tem como externalidade negativa acabar com grande parte do orçamento municipal da saúde para determinar a administração de fármaco ou de terapêutica tem de ser ponderada com a possibilidade de sua ilegalidade, ou até mesmo de sua inconstitucionalidade, a menos que o sistema normativo orçamentário retire das infrações e crimes, dispostos na LRF e legislação específica, o não cumprimento das restrições orçamentárias para os casos de determinação judicial. "Se assim for, estamos 
O princípio da eficiência é inserido no contexto constitucional como corolário do princípio da legalidade, não lhe opondo resistência. A ideia não é criar novos mecanismos de decisão na administração pública que possam ser mais eficientes em detrimento da previsão legal; ao contrário, buscam-se, dentro das alternativas oferecidas pelo ordenamento jurídico, apenas as soluções que sejam eficientes e econômicas ${ }^{136}$.

Por imposição constitucional, passa a ser vedado o comportamento de qualquer agente público que possa ser "contraproducente ou ineficiente à luz dos valores e objetivos jurídicos visados"137. Essa assertiva é válida inclusive para a interpretação e aplicação de normas legais e constitucionais, a fim de evitar que o resultado da produção jurisdicional conduza à redução do escopo da norma que se pretende tutelar - aqui, falamos em direitos fundamentais $^{138}$.

Compete ao Poder Judiciário, por sua atribuição constitucional, velar pela atuação mais eficiente e econômica da Administração como forma de ampliar, potencializar o atendimento das necessidades públicas decorrentes da efetivação dos direitos fundamentais $^{139}$.

\subsubsection{A atuação do Poder Judiciário no planejamento e execução de políticas públicas em um contexto federalista}

pela via transversa, instituindo um modelo de Estado que se obriga constitucionalmente, mas não indica meios efetivos e factíveis de cumprir todas as promessas". BLIACHERIENE, Ana Carla; MENDES, Guilherme Adolfo dos Santos. Obra citada.

136 Exige a economicidade que a Administração adote a solução mais conveniente e eficiente sob o ponto de vista da gestão dos recursos públicos. O princípio da economicidade é a expressão especializada, pecuniária, do princípio da eficiência. ARAGÃO, Alexandre dos Santos. Interpretação consequencialista e análise econômica do Direito Público à luz dos princípios constitucionais da eficiência e da economicidade. In: RAMALHO, Pedro Ivo Sebba [org.]. Regulação e Agências Reguladoras. Governança e Análise de Impacto Regulatório. 1. ed. Brasília, 2009. p. 39

137 ARAGÃO. Obra citada. p. 40.

138 "É o princípio constitucional da eficiência - art. 37, caput, CF - que deve iluminar a aplicação das regras constitucionais, legais e regulamentares, para que ela não leve a uma consecução ineficiente ou menos eficiente dos seus objetivos primários". ARAGÃO. Obra citada. p. 43.

139 "Sem dúvida, complexo se apresenta o princípio da eficiência. Mas, enquanto mandamento constitucional, o mesmo deverá ser buscado pela Administração Pública. É, e há de ser sempre, o seu dever primar - dentre outras funções - em prestar serviços eficientes para satisfazer uma parcela das necessidades imediatas e mediatas dos cidadãos, ou seja, aquelas necessidades básicas que devem ser supridas pelo Estado”. SANTANA, José Lima. O princípio constitucional da eficiência e o Sistema Único de Saúde (SUS). In: BLIACHERIENE, Ana Carla; SANTOS, José Sebastião [org.] 2010. p. 49. 
O federalismo fiscal é assunto que importa sobremaneira na formulação e execução das políticas públicas. Afinal, qual ente é responsável, constitucionalmente, por assegurar a satisfação de cada direito constitucional? Respondida essa pergunta, outra se impõe: a arrecadação desse ente corresponde às suas obrigações?

Sendo positiva a resposta à segunda questão, uma nova dúvida surge: em não se tratando do governo central (União), os demais entes subnacionais com mesma responsabilidade devem assegurar a fruição dos direitos sociais por seus cidadãos, sob pena de responderem perante os demais ou, embora constitucionalmente responsáveis poderiam permanecer inertes, valendo-se dos serviços prestados por seu "vizinho"?

Todo esse arranjo deve ser pensado não apenas no momento de elaboração de uma Constituição, mas sempre que estivermos discutindo a redistribuição de rendas entre os entes (seja essa redistribuição entendida como alteração na competência de arrecadação ou na implantação de novas formas de transferências intergovernamentais) ou de competências para satisfação de direitos de seus cidadãos.

Ao tratamos da primeira hipótese, todos os questionamentos serão levantados em sede legislativa, já que outro Poder não dispõe de atribuição para alterar normas legais ou mesmo constitucionais. No entanto, eventuais alterações legislativas que impactem diretamente nos orçamentos dos entes (central ou subnacionais) devem ser tomada em consideração quando for solicitado ao Judiciário o controle de determinada política pública.

Quanto à segunda hipótese, porém, trata-se de assunto que tem pertinência direta com o ofício desenvolvido pelo Poder Judiciário - especialmente quando resolve imiscuir-se no controle das políticas públicas.

A descentralização de competências é inerente ao regime federativo adotado pela Constituição brasileira (art. $1^{\circ}$ da Constituição), sendo responsável pela dinâmica adotada para a satisfação dos direitos sociais, seja na montagem tripartite do SUS, ou na previsão de competências mais definidas para promoção do direito à educação (art. $211, \S \S 2^{\circ}$ e $3^{\circ}$ da Constituição). 
Essas regras, no entanto, sofrem constantes ataques, daí a necessidade que expomos de que haja uma ponderação por parte do Magistrado, seja em relação à alteração na arrecadação pelo ente seja no impacto que uma decisão judicial pode produzir no equilíbrio federativo decisões que acarretem o "voto com o pé" ou o "efeito carona".

O equilíbrio entre arrecadação e atribuição deve ser ponderado em cada decisão que pretenda alterar uma política pública. Para isso, é necessário que se exponha qual a construção pensada originariamente pela Constituição e qual é a relação que existe hoje, após a edição de emendas constitucionais e demais leis infraconstitucionais, a partir dos direitos sociais previstos constitucionalmente. Dentre todos, foram separados para análise os direitos à saúde e à educação, em razão da polêmica que os envolve e em virtude do número de ocorrências observadas.

Para cada um desses direitos, faremos uma pesquisa nos tribunais superiores (STJ e STF), utilizando-os como chave de busca, fazendo delimitação temporal caso o número de julgados seja de grande monta e realizando o descarte das decisões que não importem na questão do controle de políticas públicas. Eventualmente, serão analisadas decisões proferidas por tribunais ou juízos estaduais ou regionais, quando apresentem curiosidades, novidades e soluções diferenciadas ao tema. A escolha dessas será aleatória, pois servirá apenas como ilustração para cada tópico a ser trabalhado.

\subsection{DIREITO À SAÚDE}

O direito à saúde é elevado, por vezes, a categoria de super direito, justamente porque impacta diretamente no direito à vida de cada cidadão. Em virtude disso, juntamente com o direito à educação, goza da prerrogativa de ter verbas constitucionalmente afetadas para sua garantia. Importa dizer, do total da arrecadação, parte é predestinada à execução de políticas de saúde ${ }^{140}$ e educação.

\footnotetext{
$140 \quad$ "A saúde é priorizada em termos financeiros, contando com a garantia constitucional de aplicação mínima de recursos no setor por parte de todos os entes federados, na forma do artigo 198 , parágrafo $2^{\circ}$ e $3^{\circ}$ da Constituição e na Lei Complementar 141. Recentemente a saúde foi contemplada com a destinação de parcela da arrecadação dos royalties de petróleo, na forma da Lei 12.858 , de setembro de 2013 , sem contar outras leis em vias de aprovação que dispõe no mesmo sentido, o que permite vislumbrar não ser por falta de recursos que nossa saúde anda mal”. CONTI, José Maurício. Saúde não precisa só de dinheiro, mas de boa gestão. Disponível em: http://www.conjur.com.br/2013-out-22/contas-vista-saude-nao-dinheiro-boa-gestao.
} 
Além disso, é, talvez, aquele que tenha melhor estrutura institucional desenhada no Brasil. A conjunção da Constituição de 1988, das Leis 8.080/90 e 8.142/90, e das Normas Operacionais Básicas de 1991, 92, 93 e 96 criou o Sistema Único de Saúde (SUS), responsável pela universalização do direito à saúde no Brasil.

O SUS é regido pelos princípios da universalidade, integralidade e equidade, formando uma conjunção entre União, Estados e Municípios, onde cada nível federativo dispõe de parcela de competência e responsabilidade para planejar e executar políticas públicas voltadas ao estabelecimento de protocolos clínicos, aquisição e distribuição de medicamentos, órteses, próteses e outras necessidades vinculadas às moléstias que afligem a população brasileira.

A Constituição tratou apenas de vincular a atuação dos entes federativos a esse sistema único, como forma de concentrar esforços na realização de uma só política pública que pudesse ser mais robusta que o fracionamento de políticas por todo o território nacional. Não há no texto constitucional maiores elementos acerca das formas de interação e cooperação, que foram expressamente relegadas, pelo parágrafo único do art. 23, às leis complementares.

O SUS, no entanto, foi construído a partir de mecanismos previstos em duas leis ordinárias, quais sejam, Lei 8.080/90 e Lei 8.142/90. Diante desse cenário, existem duas alternativas possíveis: entender que essas leis, especialmente a Lei 8080/90, que trata especificamente da construção do SUS, foi recepcionada pelo ordenamento como lei complementar ${ }^{141}$ ou descartar tudo o que já foi feito em prol do atendimento ao direito à saúde, já que a Constituição exige que as formas de cooperação sejam veiculadas por leis complementares.

Obviamente, entendemos que a Lei 8080/90 ingressou no ordenamento jurídico com status de lei complementar e retira seu substrato de validade diretamente do parágrafo único do art. 23 da Constituição. Essas duas leis mencionadas, no entanto, não conseguem tratar sobre todas as questões atinentes à efetivação do direito à saúde no Brasil, razão pela qual autorizam que normas infralegais possam dispor, pontualmente, sobre matérias específicas.

$141 \quad$ Nesse sentido, SANTOS. 2012. 
Assim, abre-se espaço no ordenamento para as Normas Operacionais Básicas e as Portarias do Ministério da Saúde, que dispõem, dentre outros assuntos, sobre a transferência de recursos da União para Estados e Municípios e os critérios para seu recebimento e a responsabilidade de cada um dos Entes dentro do SUS ${ }^{142}$.

Essa é a primeira premissa que deve ser observada ao tratarmos do tema de controle de políticas públicas em relação ao direito à saúde: ao contrário do que afirmam os Tribunais, as divisões previstas em Portarias do Ministério da Saúde não são menos importantes nem tampouco conflitantes com a previsão constitucional, já que dela extraem sua validade, intermediada pela Lei 8080/90.

Embora o arranjo institucional seja tripartite e conte com a responsabilidade de todos os entes, a União é encarregada do financiamento e da formulação da política nacional de saúde, assim como o é da coordenação das ações intergovernamentais ${ }^{143}$.

\begin{abstract}
Isso significa que o Governo Federal [...] tem autoridade para tomar as decisões mais importantes nesta política setorial [...] a principal arena de formulação da política nacional tem sido o próprio Poder Executivo. O conteúdo dessas portarias consiste, em grande medida, em condicionar as transferências federais à adesão de Estados e Municípios aos objetivos da política federal ${ }^{144}$.
\end{abstract}

Vê-se, portanto, que embora a previsão constitucional atribua responsabilidade a todos os entes da federação, a União concentra poderes e rendas que devem encontrar mecanismos de repasse para os demais entes, como forma de potencializar a execução das políticas da saúde. E mais, no caso da saúde, ainda existe outra situação peculiar, que é a compra de medicamentos.

Os medicamentos não são como canetas, cadeiras ou computadores, que possuem diversos fabricantes aptos a fornecê-los ${ }^{145}$. Ao contrário, muitas vezes apenas um fabricante pode

\footnotetext{
142 "Isso significa que o governo federal"... tem autoridade para tomar as decisões mais importantes nesta política setorial... a principal arena de formulação da política nacional tem sido o próprio poder Executivo. O Conteúdo dessas portarias consiste, em grande medida, em condicionar as transferências federais à adesão de Estados e Municípios aos objetivos da política federal. ARRETCHE, Marta. Federalismo e Políticas Sociais no Brasil. In: São Paulo em perspectiva, 18(2): 17-26, 2004.

143 ARRETCHE. 2004.

144 ARRETCHE, 2004.

145 "No nível das unidades de atenção, as restrições impostas pelas regras do setor público no que diz respeito à gestão de recursos humanos e a compras são geralmente apontadas como as principais fontes de
} 
vender determinado medicamento, por tê-lo patenteado. Diante desse fato, pergunta-se: as compras emergenciais desnecessárias ${ }^{146}$ não feririam os princípios constitucionais da economia e da eficiência, à luz do processo de compra previsto pela Lei 8666/93?

E nas situações em que a União procedeu ao licenciamento compulsório e detém a fórmula, o know how e a mão de obra para produção de determinado medicamento, mesmo assim os demais entes federativos teriam iguais obrigações em fornecê-los? Diante desse cenário, como o Judiciário vem se portando ao decidir questões relativas ao direito à saúde?

A questão que deixa de ser observada é que não se trata de uma restrição ao direito fundamental em si, mas apenas de observância do ente competente para sua adequada satisfação. Defender que cada ente federativo possa ser cobrado em juízo por sua responsabilidade prevista em por lei ou outro ato normativo, não é levantar um obstáculo à sua efetivação.

Ao contrário!

O que se busca é, justamente, garantir uma melhor e mais adequada prestação do direito fundamental que seja, em adição, concorde com demais princípios constitucionais, tais como da eficiência e da economicidade.

A Constituição de 88 não deixa espaços para que o administrador público, por mais inábil que seja, inviabilize a prestação do direito à saúde em qualquer nível federativo. Ele está inserido na fundamentalidade do rol dos direitos sociais (art. $6^{\circ}$ ) e deve ser atendido por todos os níveis administrativos da federação (art. 23, 196 e 198).

Essa construção normativa, apesar de grande trunfo contra o baixo índice de atenção à saúde da população brasileira, tem sido a grande responsável pela interpretação equivocada do direito à saúde feita pelos tribunais brasileiros.

problemas". IPEA. Políticas Sociais. Acompanhamento e Análise. N. 18. 2010. Saúde. Disponível em: http://www.ipea.gov.br/portal/images/stories/PDFs/politicas_sociais/bps_18_cap04.pdf

146 Consideramos compras emergenciais desnecessárias aquelas impostas a um determinado ente federativo que não dispõe do medicamento para pronta entrega quando outro ente o tem em estoque por ser, pelas normas balizadoras do SUS, o responsável direto por sua dispensação. 
O período que antecede a Constituição de 88 é marcado por grandes ausências do Estado nos setores prioritários. A tentativa de evitar a perpetuação desse modelo fez com que o constituinte optasse, como dito anteriormente, por uma estrutura de federalismo cooperativo, com políticas homogeneizadas a partir da coordenação do ente central e execução partilhada entre todos os entes ${ }^{147}$.

E o melhor exemplo disso é o Sistema Único de Saúde, construído para ser uma forçatarefa, um catalisador de esforços, por força da proibição dirigida a todos os entes de planejarem ou executarem ações e políticas voltadas à saúde fora de seu âmbito ${ }^{148}$. O que não importa dizer, porém, que a redação dos arts. 196 e 198 da Constituição aponte para a existência solidariedade de todos os entes em relação à execução de todas as políticas de saúde.

Apesar disso, por meio da construção de um entendimento que aqui se julga inadequado a toda estrutura da Constituição, os tribunais brasileiros vêm determinando indiscriminadamente que qualquer um dos entes seja obrigado a custear qualquer medicamento ou tratamento pleiteado judicialmente.

Ao propor a existência de uma rede descentralizada e hierarquizada, disposta em um sistema único $^{149}$ (art. 198, caput) e com direção única em cada esfera de governo (inciso I), o constituinte não buscou outra coisa senão a catalisação de esforços dos entes federados para construção de uma política uniforme e coesa, com equilíbrio na atribuição de

\footnotetext{
$147 \quad$ "...] claro desejo do legislador constituinte de que, diferentemente do modelo anteriormente adotado, não mais fosse permitido a nenhum dos entes federados promover ações ou serviços públicos de saúde fora do regime único do SUS. Tal regra acabou efetivamente se convertendo em um dos pilares fundamentais para a mudança da saúde pública brasileira sob o ponto de vista federativo, uma vez que, como relatado no tópico anterior, um dos seus grandes problemas era justamente a total ausência de coordenação entre os entes, que mantinham sistemas próprios e isolados entre si." LEBRÃO, Roberto Mercado. Federalismo e Políticas Sociais na Constituição de 1988. In: CONTI, José Maurício et alli. 2010. p. 368.

$148 \quad$ "É vedado a qualquer ente político-administrativo constituir um plano ou programa de saúde à parte do SUS, posto que a Constituição cria um sistema de serviço público unificado e fundado na obrigatória conjugação de esforços". SILVEIRA, Alessandra. Cooperação e compromisso constitucional nos Estados Compostos. Estudo sobre a teoria do federalismo e a organização jurídica dos sistemas federativos. Coimbra: Almedina, 2007.

149 "A questão central a entender na concepção do SUS é o conteúdo da unidade. O que deve ser único no sistema de saúde? A resposta começa a ser dada pela própria Lei Maior, no art. 198, em especial o caput e o inciso I". WEICHERT, Marlon Alberto. O Sistema Único de Saúde no federalismo brasileiro. In: Revista de Direito Constitucional e Internacional. Ano 8. n. 32. São Paulo: RT, jul-set. 2000. p. 168
} 
competência a cada nível do governo de forma a evitar áreas cinzentas, com déficit de atuação ou sobreposição, com desperdício de recursos ${ }^{150}$.

A solidariedade faz parte do arranjo federalista instituído pela Constituição como fio condutor da atuação política e administrativa - ela existe enquanto fundamento da Federação ${ }^{151}$-, o que não quer dizer que, todas as obrigações assumidas pelos entes sejam contraídas juntamente pelos demais, em regime solidário.

A montagem do sistema único, do qual todos os entes são obrigados ${ }^{152}$ constitucionalmente a participar é feita de maneira solidária: desde a elaboração das diretrizes e o aporte de recursos até a entrega do serviço a cada cidadão que busca a rede de assistência.

Essa rede deve ser construída de forma hierarquizada e regionalizada. Quer dizer, ela deve aproveitar a estrutura federativa para se espalhar por todo o território nacional (regionalização) com cuidados que vão da atenção básica ${ }^{153}$ até os cuidados de alta complexidade, que serão fornecidos pelo ente que reúne melhores condições de provê-los (hierarquia) $^{154}$.

$150 \quad$ Analisando a estrutura proposta pelo art. 198 da Constituição, "a segunda conclusão que pode ser extraída de referido dispositivo é a indiscutível carga de 'descentralização coordenada' atribuída às políticas de saúde, por meio da definição de um modelo baseado em uma rede regionalizada e hierarquizada, porém com direção única em cada esfera de governo. Nesse ponto, é preciso destacar que, ao se referir a uma rede hierarquizada [...] sua intenção foi evidenciar que o sistema único ali definido se baseava em um modelo de atendimento à população com diferentes níveis de complexidade técnica, buscando evitar uma sobreposição de ações que levariam a um maior desperdício dos recursos destinados ao SUS". LEBRÃO. Obra citada. p. 369

151 "Como a Federação brasileira tem por fundamento a solidariedade, que exige a colaboração de todos os seus integrantes, existe a necessidade de uniformização de certos interesses como base desta cooperação". BERCOVICI. 2009. p. 14.

152 "A primeira mensagem que se obtém da leitura do dispositivo é a obrigatoriedade de todos os entes integrarem o sistema [...] Entendemos, pois, que a constituição não faculta o ingresso do ente público no sistema, mas, pelo contrário, impõe que todos eles sejam membros dele". WEICHERT. Obra citada. p. 168 153 “A municipalização, por sua vez, é um processo de descentralização da gestão pública na esfera do governo local, tendo como pressuposto o entendimento de que as políticas públicas se concretizam nesta instância, em que está localizada a população a que devem atender”. BRASIL. Ministério da Saúde. Secretaria de Gestão Estratégica e Participativa. A construção do SUS: histórias da Reforma Sanitária e do processo participativo. Brasília: Ministério da Saúde, 2006. p. 26.

154 "ao se referir a uma rede hierarquizada, a Constituição não estabeleceu uma prevalência de um ente sobre o outro. A hierarquização aí referida diz respeito à organização da rede de assistência, que, além de regionalizada, deverá ser estruturada de modo a compartilhar hospitais de atendimento complexo. Ou seja, deve haver uma hierarquia de complexidade na rede, de modo a otimizar os recursos disponíveis. Com isso, evita-se a sobreposição de estruturas de atendimento e o desperdício das escassas verbas públicas". WEICHERT. Obra citada. p. 169. 
Cada esfera de governo recebe sua parcela de responsabilidade e de autonomia, podendo livremente executar os planos de ação na área da saúde, desde que sempre dentro do guarda chuva do SUS - essa é a direção única estipulada pelo inciso I do art. $198^{155}$.

Seguindo esse raciocínio, a Portaria $n^{\circ}$ 399/GM de 22 de fevereiro de 2006, definiu detidamente as responsabilidades de cada um dos níveis de governo na gestão do SUS, em homenagem à pretendida descentralização e como mecanismo de fortalecimento das próprias políticas de saúde.

Dois extremos são apresentados. De um lado, a capilaridade dos municípios que os torna os entes mais eficientes da rede de assistência (pressionando o movimento descentralizador), mas que não dispõem de recursos materiais e humanos suficientes para dar conta de uma escalada na demanda por serviços especializados; de outro, a União, centralizada, longe da maior parte da população nacional, mas com plenos poderes de gestão sobre o sistema e detentora da maior fatia do bolo tributário e do maior contingente de servidores. É preciso resolver essa equação.

Para que o SUS tenha ganho de eficiência é indispensável que os municípios possam assumir todas as responsabilidades que lhes têm sido atribuídas pelas normas definidoras do sistema. Mas, para isso, precisariam superar as fraquezas apontadas acima ${ }^{156}$.

Em relação à disponibilidade financeira, os municípios ficam à mercê do recebimento das transferências realizadas pela União em blocos de financiamento ${ }^{157}$ que, de acordo com a Portaria GM/MS no 204/2007, são definidas com base em proposta dos gestores. Essas transferências ocorrem fundo a fundo ${ }^{158}$ e têm por objetivo o financiamento das políticas

155 "A segunda conclusão obtida, sem maiores dificuldades, é de que cada governo terá poder de direção sobre os seus serviços. No entanto, essa direção será única, ou seja, deverá estar centrada em apenas um órgão". WEICHERT. Obra citada. p. 168.

156 TAVARES DE ALMEIDA. Obra citada.

157 Art. $3^{\circ}$ Os recursos federais destinados às ações e aos serviços de saúde passam a ser organizados e transferidos na forma de blocos de financiamento.

Parágrafo único. Os blocos de financiamento são constituídos por componentes, conforme as especificidades de suas ações e dos serviços de saúde pactuados.

${ }_{158} \quad$ Art. $5^{\circ}$ Os recursos federais que compõem cada bloco de financiamento serão transferidos aos Estados, ao Distrito Federal e aos Municípios, fundo a fundo, em conta única e específica para cada bloco de financiamento, observados os atos normativos específicos. Em relação à distribuição de recursos para o SUS, CONTI, José Maurício. Saúde não precisa só de dinheiro, mas de boa gestão. http://www.conjur.com.br/2013-out-22/contas-vista-saude-nao-dinheiro-boa-gestao: "Em matéria orçamentária, o Sistema Único de Saúde (SUS) é financiado com recursos "do orçamento da seguridade 
voltadas aos tratamentos de atenção básica, média e alta complexidade ambulatorial e hospitalar, à vigilância em saúde, à assistência farmacêutica e à própria gestão do SUS ${ }^{159}$.

Mas, não apenas as propostas dos gestores determinam o montante das transferências. $\mathrm{O}$ perfil demográfico da região, o perfil epidemiológico da população a ser coberta, as características quantitativas e qualitativas da rede de saúde da área, o desempenho técnico, econômico e financeiro no período anterior, os níveis de participação do setor da saúde nos orçamentos estaduais e municipais, a previsão do plano quinquenal de investimentos na rede e o ressarcimento do atendimento a serviços prestados para outras esferas de governo são os critérios usados para o estabelecimento de valores a serem transferidos aos entes subnacionais, conforme dispõe o art. 35, da Lei 8080/90 combinado com o art. $2^{\circ}$ da Lei 8142/90.

Esse ponto merece destaque. Dentre os critérios determinantes do valor a ser transferido a um dos entes subnacionais pela União um deles é o nível de comprometimento do orçamento com gastos com a saúde e outro, o ressarcimento do atendimento a serviços prestados para outras esferas de governo. Se o Judiciário respeitar as divisões formuladas pelas Portarias Ministeriais, mais calibrado será o sistema ${ }^{160}$.

Veja-se. Quanto maior a aceitação de demandas diretamente em face da União, menor será o comprometimento dos orçamentos subnacionais com a saúde e menor será o volume de recursos que irão receber. Pela mesma razão, sendo a União responsabilizada diretamente pela execução de um serviço dentro do SUS ela não irá prestar qualquer reembolso ao ente que seria o responsável originário pela sua prestação.

social, da União, dos Estados, do Distrito Federal e dos Municípios, além de outras fontes”, explicita o parágrafo $1^{\circ}$ do artigo 198. Ou seja, por todos os entes da federação. Recursos estes cuja distribuição dá-se por um sofisticado mecanismo de financiamento, operacionalizado por meio do Fundo Nacional de Saúde e os fundos estaduais e municipais de saúde, compondo um sistema de transferências intergovernamentais fundo a fundo. Sem esquecer da intensa participação, com remuneração pelos cofres públicos, de entidades públicas, filantrópicas e organizações não governamentais".

${ }_{159} \quad$ Art. $4^{\circ}$ Estabelecer os seguintes blocos de financiamento:

I - Atenção Básica;

II - Atenção de Média e Alta Complexidade Ambulatorial e Hospitalar;

III - Vigilância em Saúde;

IV - Assistência Farmacêutica; e

V - Gestão do SUS.

160 Na regulamentação do Pacto pela Saúde, foram estabelecidas as responsabilidades sanitárias de cada ente federado, organizadas em sete eixos: i) na gestão do SUS; ii) na regionalização; iii) no planejamento e na programação; iv) na regulação, no controle, na avaliação e na auditoria; v) na gestão do trabalho; vi) na educação e na saúde; e vii) na participação e no controle social. IPEA. 2010. 
A leitura apressada dessa conclusão pode revelar o óbvio: não existe prejuízo, pois se o Estado ou Município não têm o gasto e não recebem compensação por isso, temos um jogo de soma zero. Mas, não!

Sendo o SUS marcadamente descentralizado (art. 198, I da Constituição), ele precisa privilegiar o acesso da população, ainda que em locais mais remotos, às estruturas de saúde que devem ser fornecidas pelos entes mais aptos. $O$ ente central não pode, não deve e não consegue ficar vinculado à execução das políticas mais pontuais e localizadas. Isso é contra a própria estrutura federativa escolhida pela Constituição ${ }^{161}$.

Os Estados e Municípios também devem estabelecer aporte de rendas no SUS, conforme determinam os arts. 198, $\S 1^{\circ}$ da e $2^{\circ}$ da Portaria GM/MS 204/2007. Ao se levar em consideração que um considerável número de municípios tem por fonte principal de renda as transferências realizadas pela União, chega-se facilmente à conclusão que o financiamento do SUS provém, substancialmente, do governo central - a quem compete a criação e arrecadação dos tributos destinados à seguridade social.

Logo, embora os gestores do SUS tenham potencialmente condições de influenciar no processo de distribuição e alocação de recursos, muitos dos critérios determinantes da transferência de valores entre a União e os demais entes subnacionais estão prefixados em normas constitucionais e legais.

\footnotetext{
161 "A descentralização dos encargos em matéria de saúde é complexa e delicada, em face das especificidades do setor, uma vez que há múltiplos fatores a serem levados em consideração. Urgência, gravidade, complexidade, custo, demanda - há muitos itens a sopesar na delimitação de quem vai fazer o que e como. E imperfeições nessa alocação geram efeitos perversos para todos. Quantas vezes não se constata na área da saúde a ocorrência de fenômenos conhecidos dos estudiosos de federalismo fiscal, como o free rider efect, ou "efeito carona", em que determinadas unidades da federação, especialmente os municípios, por fornecerem esse serviço público com competência e eficiência, atraem para si pacientes de outros municípios, e acabam arcando com as despesas para o tratamento de um cidadão que não reside em seu território. Prefeitos que, ao invés de se esforçarem para construir e manter postos de saúde e hospitais que prestem um serviço de boa qualidade, optam por comprar ambulâncias que levam os pacientes para serem atendidos em municípios vizinhos, e com isso deixam de arcar com altas despesas, onerando outro ente da federação. Organizar todos estes fatores de modo e construir um sistema eficiente e evitar externalidades de toda sorte é tarefa árdua, a exigir muito esforço, estudo e dedicação, que depende ainda de muita vontade política para ser implementado, tornando-o realidade". CONTI, José Maurício. Saúde não precisa só de dinheiro, mas de boa gestão. http://www.conjur.com.br/2013-out-22/contas-vista-saude-nao-dinheiro-boagestao
} 
Para além de contar com o poderio financeiro, a União, por meio do Ministério da Saúde, é quem determina a forma de divisão de responsabilidade entre os entes subnacionais, seja em relação à dinâmica de compra e distribuição de medicamentos, seja quanto às demais ações do setor ${ }^{162}$.

O valor repassado é suficiente para financiar o referido bloco de atenção, sendo definido a partir das características de cada local e pactuado nas Comissões Intergestoras Tripartite (CIT) e Bipartite (CIB), havendo a possibilidade de interposição de recurso por parte dos municípios ou dos estados quando discordarem dos valores repassados, conforme disciplina o artigo 15 da Portaria nº 699/2006 do Ministério da Saúde. Porém, os recursos não podem ser usados para construção de novas unidades - hospitais e clínicas.

Os argumentos aqui apresentados não dizem respeito ao mínimo existencial ou à reserva do possível, tampouco podem ser rechaçados pela existência de corrupção, desvios e uso inadequado das verbas públicas. Não se está a defender a limitação do direito à saúde; ao contrário, pretende-se seu melhor atendimento, por meio do aperfeiçoamento do SUS, que anda sendo desfigurado pelas decisões judiciais cada vez mais frequentes em relação à matéria.

Ao julgar a Suspensão de Tutela Antecipada n 91 (DJ 05/03/2007), que visava a suspensão de decisão judicial que impunha ao Estado de Alagoas a obrigação de fornecer os medicamentos necessários aos pacientes renais crônicos em hemodiálise ou transplantados, a Ministra Ellen Gracie ponderou que

\footnotetext{
[...] a gestão da política nacional de saúde, que é feita de forma regionalizada, busca uma maior racionalização entre o custo e o benefício dos tratamentos que devem ser fornecidos gratuitamente, a fim de atingir o maior número possível de beneficiários.

Entendo que a norma do art. 196 da Constituição da República, que assegura o direito à saúde, refere-se, em princípio, à efetivação de políticas públicas que alcancem a população como um todo, assegurando-lhe acesso universal e igualitário, e não a situações individualizadas. A responsabilidade do Estado em fornecer os recursos necessários à reabilitação da saúde de seus cidadãos não pode vir a inviabilizar o sistema público de saúde.
}

162 “As políticas traçadas pelo Ministério da Saúde estabelecem a divisão de responsabilidades das esferas de governo, no que se refere à aquisição e distribuição de medicamentos, com competências complementares entre os gestores”. BARRADAS BARATA, Luiz Roberto; MENDES, José Dínio Vaz. Uma proposta de política de assistência farmacêutica para o SUS. In: BLIACHERIENE, Ana Carla; SANTOS, José Sebastião [org.] 2010. p. 63. 
A Ministra Ellen Gracie, acertadamente, destacou que a razão pela qual o SUS tem como marca a forte descentralização é justamente a necessidade de se alcançar a população como um todo. Logo, há perigo quando a tutela do direito de uma pessoa põe em xeque a tutela do direito de toda a coletividade. Sem desmerecer a fundamentalidade do direito apresentado, mas, reconhecendo que o sistema precisa funcionar com racionalidade, a Ministra afirmou que:

\begin{abstract}
a tutela concedida atinge, por sua amplitude, esferas de competência distintas, sem observar a repartição de atribuições decorrentes da descentralização do Sistema Único de Saúde, nos termos do art. 198 da Constituição Federal. Finalmente, verifico que o Estado de Alagoas não está se recusando a fornecer tratamento aos associados (fl. 59). É que, conforme asseverou em suas razões. “(...) a ação contempla medicamentos que estão fora da Portaria $n .{ }^{\circ} 1.318 \mathrm{e}$, portanto, não são da responsabilidade do Estado, mas do Município de Maceió, (...)" (fl. 07), razão pela qual seu pedido é para que se suspenda a "(...) execução da antecipação de tutela, no que se refere aos medicamentos não constantes na Portaria n. ${ }^{\circ} 1.318$ do Ministério da Saúde, ou subsidiariamente, restringindo a execução aos medicamentos especificamente indicados na inicial, (...)" (fl. 11).
\end{abstract}

Feitas pesquisas com as palavras chaves "repartição e atribuições e 'sistema único de saúde"" ou repartição e competência e "sistema único de saúde" em três datas distintas, sendo a última 14 de setembro de 2013, não foi encontrado outro precedente do STF que sustentasse a mesma ideia ${ }^{163}$.

Porém, no mesmo ano em que foi proferida a decisão da Presidência na STA n ${ }^{\circ}$ 91, o Ministro Celso de Mello decidiu monocraticamente o AI $n^{\circ} 583067 / R S$, em $1^{\circ}$ de outubro de 2007, ocasião na qual defendeu o conceito de solidariedade social do Poder Público, como forma de impor a todos os entes a responsabilidade pela prestação de políticas públicas de saúde.

Essa ideia foi apresentada, novamente, durante o julgamento da Suspensão de Segurança 3.355-AgR/RN, tendo em vista que o Relator, Ministro Gilmar Mendes, defendeu a obrigação solidária de todos os entes federativos em relação ao direito à saúde.

O julgamento da $\mathrm{SS} \mathrm{n}^{\mathrm{o}}$ 3.355-AgR/ RN não pode ser tido, porém, como precedente favorável à imposição de responsabilidade solidária entre todos os entes federativos. Em primeiro lugar, o Relator não abordou o tema de maneira fundamentada. Rapidamente,

163 Os termos da busca foram definidos a partir dos utilizados no precedente "paradigma". 
disse em seu voto que elementos colhidos na audiência reforçam a responsabilidade solidária. No entanto, os elementos apresentados foram apenas as conclusões dos julgamentos dos RE 195.192-3/RS e 255.627-1/RS. Nenhum argumento apresentado na audiência pública serviu para dar sustentação à tese. Portanto, se havia elementos, a decisão os omitiu.

Quando a Ministra Ellen Gracie proferiu seu voto, demonstrou preocupação com a pluralidade de causas que podem surgir no contexto da tutela do direito à saúde e sua preocupação com generalizações que possam atrapalhar a análise casuística de problemas que são singulares. Como resposta, o Ministro Gilmar Mendes disse que o tema da responsabilidade era matéria que seria tratada em outro julgamento, no do RE 566.471/RN, de relatoria do Ministro Marco Aurélio Mello.

Outro argumento contrário foi apresentado pelo próprio Relator, ao afirmar que as alegações referentes "à necessidade de figurar como réu na ação principal somente o ente responsável pela dispensação do medicamento pleiteado e à desconsideração da lei do SUS, não são passíveis de ampla delibação no juízo do pedido de suspensão de segurança, pois constituem o mérito da ação" (fl. 103)

No RE 566.471/RN, porém, o reconhecimento da existência de repercussão geral recai sobre "a obrigatoriedade de o Poder Público fornecer medicamento de alto custo"164, portanto mais vinculada à questão de restrição orçamentária e não da dinâmica de distribuição de competência e responsabilidade. Essa questão, portanto, permanecerá sendo objeto de julgamentos pontuais, com remissão aos precedentes existentes na Corte.

Outras pesquisas feitas, nas mesmas datas indicadas anteriormente, com os termos "responsabilidade e solidária e "sistema único de saúde"” e "direito e saúde e solidariedade e ente e federativo" indicou a existência de oito precedentes (três entradas para a primeira busca e cinco para a segunda) que defendem a responsabilidade indistinta de todos os entes em relação a pleitos inerentes ao direito à saúde.

164 BRASIL. Supremo Tribunal Federal. RE 566471 RG, Relator(a): Min. MARCO AURÉLIO, julgado em 15/11/2007, DJe-157 DIVULG 06-12-2007 PUBLIC 07-12-2007 DJ 07-12-2007 PP-00016 EMENT VOL-02302-08 PP-01685. 
O tema, portanto, vem sendo tratado no STF de forma apressada e superficial, sempre com a designação da questão financeira como secundária como se a pretensão fosse opor finanças públicas e saúde, ou seja, ou dinheiro ou medicamento ${ }^{165}$. Não! A ideia é permitir uma estrutura de divisão racional de responsabilidades para que todos possam ser atendidos.

No STJ, muitos são os precedentes que aplicam indiscriminadamente o conceito de responsabilidade solidária para condenar qualquer que seja o ente demandado a cobrir os custos do tratamento pleiteado judicialmente. Buscas sucessivas realizadas no site do STJ, sendo a última em 15 de setembro de 2013, com as chaves "direito e saúde e solidariedade e ente e federativo" apontaram para oito precedentes, sendo todos favoráveis ao reconhecimento da responsabilidade solidária entre os três níveis federativos.

Já a busca com as palavras chaves "responsabilidade e solidária e 'sistema único de saúde", na mesma data, resultou em um total sessenta e um precedentes. Desses, cinquenta e dois aplicam a tese da responsabilidade solidária entre todos os entes. Dos nove excluídos: (i) dois afastam expressamente a incidência do tema ${ }^{166}$; (ii) dois contêm julgamento de responsabilidade civil da União por erro médico cometido em hospital público $^{167}$ e em hospital privado quando da realização de procedimento custeado pelo SUS $^{168}$; (iii) dois foram extintos por questões processuais, quais sejam, por perda superveniente do interesse recursal ${ }^{169}$ e incompetência do STJ ${ }^{170}$; (iv) um aborda questão

\footnotetext{
165 Em crítica bastante oportuna sobre a exclusão do interesse econômico na demanda como forma argumento legítimo a sustentar o ingresso de um terceiro em uma lide pendente, CABRAL, Antonio do Passo. Interesse ad agire e zone di interesse. Disponível em: https:/uerj.academia.edu/AntonioCabral. "In effetti, nell'escludere l'interesse economico o qualsiasi materiale, il concetto tradizionalle d'interesse giuridico segrega dall'accesso alla giustizia numerose situazioni in cui interessi materiali collaterali sorgono in decorrenza del processo ed agli individui coinvolti non viene aperta la porta del processo"

166 BRASIL. Superior Tribunal de Justiça. AgRg no AREsp 40027/SC, Relatoria Ministro Humberto Martins; AgRg no AREsp 28136/SC, Relatoria Ministro Herman Benjamin

167 BRASIL. Superior Tribunal de Justiça. REsp 513660/RS, Rel. Ministro LUIZ FUX, PRIMEIRA TURMA, julgado em 20/11/2003, DJ 19/12/2003, p. 346

168 BRASIL. Superior Tribunal de Justiça. REsp 717800/RS, Rel. Ministra DENISE ARRUDA, PRIMEIRA TURMA, julgado em 25/03/2008, DJe 30/06/2008.

169 BRASIL. Superior Tribunal de Justiça.AgRg no REsp 102213/SC, Relatoria Ministro Humberto Martins

170 BRASIL. Superior Tribunal de Justiça. MS 10724/DF, Rel. Ministra ELIANA CALMON, Rel. p/ Acórdão Ministro LUIZ FUX, PRIMEIRA SEÇÃO, julgado em 26/04/2006, DJ 12/06/2006, p. 408.
} 
relativa ao ressarcimento do SUS por plano de saúde privado ${ }^{171} \mathrm{e}$; (v) dois defendem a ideia exposta nesse trabalho ${ }^{172}$.

A segunda pesquisa, de resultado mais abrangente, contém seis precedentes da primeira. Portanto, somando-se os $\mathbf{5 2}$ precedentes da segunda busca com os dois diferentes obtidos na primeira, foram encontrados $\mathbf{5 4}$ precedentes favoráveis à tese da solidariedade entre os entes federativos em processos judiciais que visam à tutela do direito à saúde em qualquer de suas dimensões.

No julgamento recente do AgRg no REsp no 1102254/RS, o Ministro Napoleão Nunes Maia Filho afirma que o tema é pacificado nas Turmas que compõem a Primeira Seção e aponta que o REsp $n^{\circ} 1.144 .382 / \mathrm{AL}$, que tratava especificamente a matéria, havia sido afetado ao regime dos recursos repetitivos, previsto no art. 543-C do CPC, tendo sido, porém, desafetado em 12 de dezembro de 2012.

A razão de o STJ ter sobrestado sua manifestação acerca da matéria no julgamento do REsp $\mathrm{n}^{\mathrm{o}}$ 1.144.382/AL, foi o reconhecimento de repercussão geral sobre a matéria pelo STF nos RE nº 566.471-6 e 605.533.

Acontece que, no RE no 566.471-6 a matéria sobre a qual o STF decidiu haver repercussão geral diz respeito, como já dito, à responsabilidade de o Estado custear medicamentos de alto custo. E no RE 605.533, o reconhecimento da repercussão geral foi sobre "a legitimidade do Ministério Público para ajuizar ação civil pública com objetivo de compelir entes federados a entregar medicamentos a pessoas necessitadas" ${ }^{173}$. Nota-se que as análises sobre o tema são sempre superficiais, ao ponto de haver confusão em matérias claramente definidas nos votos de reconhecimento de repercussão geral publicados pelo STF.

171 BRASIL. Superior Tribunal de Justiça. AgRg no REsp 866393/RJ, Rel. Ministro LUIZ FUX, PRIMEIRA TURMA, julgado em 03/04/2008, DJe 24/04/2008.

$172 \quad$ BRASIL. Superior Tribunal de Justiça.AgRg no Ag 879975/RS, Relatoria Ministro José Delgado; REsp 873196/RS, Relatoria Ministro Teori Albino Zavascki.

173 BRASIL. Supremo Tribunal Federal. RE 605533 RG, Relator(a): Min. MARCO AURÉLIO, julgado em 01/04/2010, DJe-076 DIVULG 29-04-2010 PUBLIC 30-04-2010 EMENT VOL-02399-09 PP02040 LEXSTF v. 32, n. 377, 2010, p. 243-246 
O Ministro Teori Albino Zavascki, ainda no STJ, manifestou entendimento favorável à tese defendida nesse trabalho, tendo sido vencedor em dois julgamentos distintos, a saber:

\begin{abstract}
Atendendo ao preceito constitucional, a Lei 8.080/90 tratou da organização do SUS, inclusive no que se refere à distribuição das competências, das atribuições e das responsabilidades de seus vários órgãos integrantes, com o objetivo, não apenas de evitar a sobreposição de estruturas administrativas, mas para conferir eficiência, economicidade e agilidade ao sistema, condição indispensável a garantir aos cidadãos, da melhor maneira possível, o acesso universal e igualitário aos serviços de saúde. (AgRg no REsp 888.975/RS, Rel. Ministro LUIZ FUX, Rel. p/ Acórdão Ministro TEORI ALBINO ZAVASCKI, PRIMEIRA TURMA, julgado em 16/08/2007, DJ 22/10/2007, p. 205) (REsp 873.196/RS, Rel. Ministro JOSÉ DELGADO, Rel. p/ Acórdão Ministro TEORI ALBINO ZAVASCKI, PRIMEIRA TURMA, julgado em 03/05/2007, DJ 24/05/2007, p. 328$)^{174}$
\end{abstract}

Esses dois votos foram os únicos que trouxeram uma análise detida sobre a divisão de competências, atribuições e responsabilidades entre os entes federativos. Todos os demais apresentados como favoráveis à ideia de existência de responsabilidade solidária, seja no STF ou no STJ passaram ao largo da discussão, limitando-se a repetir outros precedentes que defenderam a mesma ideia a partir dos artigos 196 e 198 da Constituição.

Esse posicionamento reiterado das Cortes superiores tem por base o atendimento indispensável da saúde à população menos afortunada. Ou seja, o argumento de apelo é calcado na hipossuficiência financeira daquele que demanda, sem que se faça menção a qualquer indicativo do impacto social que têm essas ações.

O Judiciário não aponta dados indicativos de melhora nas políticas públicas de saúde, embora ordene a compra indiscriminada dos mais variados medicamentos por qualquer um dos entes federativos que seja demandado. Em contrapartida, pesquisa realizada pela Organização Mundial da Saúde no ano de 2003 revela que oitenta e sete por cento dos brasileiros tiveram acesso aos medicamentos indicados por seus médicos ${ }^{175}$.

174 Únicos precedentes, de idêntico teor, encontrados em procura realizada no site do STJ, no dia 7.9.13, sem utilização de filtro por data, com indicação das seguintes chaves de busca: direito e saúde e medicamento e eficiência. Na mesma data, a utilização das mesmas chaves de busca com exclusão do termo medicamento resultou em 11 precedentes encontrados. No entanto, nenhum tratava da matéria com a abordagem aqui pretendida, razão pela qual a opção foi por uma busca mais restritiva, porém com maior aproveitamento.

175 "Os dados da Pesquisa Mundial de Saúde - 2003 realizada pela Organização Mundial de Saúde (OMS) em 71 países e que no Brasil foi coordenada por pesquisadores da Fundação Oswaldo Cruz (FIOCRUZ) comprovaram que $87 \%$ dos brasileiros tiveram acesso aos medicamentos prescritos. Esse índice é muito elevado e contribui sobremaneira para melhoria das condições de saúde de todos os brasileiros". BARRADAS BARATA, Luiz Roberto; MENDES, José Dínio Vaz. Obra citada. p. 63 
Será que esse índice tem aumentado pela intervenção constante do Judiciário nas políticas de saúde do SUS ou, ao revés, o único resultado digno de nota é uma desordem administrativa que acarreta inversão nas prioridades elencadas pelo Executivo? Octávio Ferraz alerta, ainda, para a possibilidade de ocorrência de um resultado nulo derivado da judicialização ${ }^{176}$. Para a ideia desenvolvida nesse estudo, a neutralidade de resultados não é possível, uma vez que restariam ao menos os efeitos perniciosos da judicialização nos orçamentos dos entes federativos demandados por obrigações fora de suas atribuições.

O resultado negativo não pode ser aceito no cenário de constitucionalidade das políticas públicas e de sua instrumentalidade em favor da redução das desigualdades regionais. Como ressaltado pelo próprio Octávio Ferraz, assim como as decisões administrativas devem impactar positivamente nas condições sanitárias da camada mais pobre da população, também as decisões decorrentes de processos judiciais devem estar submetidas a essa lógica ${ }^{177}$.

Ocorre que as pesquisas que vêm sendo realizadas nesse campo de estudo têm demonstrado que as intervenções judiciais na área da saúde não refletem melhoria nas condições sanitárias dos mais desfavorecidos ${ }^{178}$. Como causa desse resultado, Daniel Wang aponta: (i) a dificuldade ainda existente em relação ao acesso à justiça pelos mais pobres, por conta do custo financeiro e; (ii) o isolamento cognitivo do Judiciário em relação aos aspectos globais das políticas públicas sociais e sua falta de diálogo com os demais Poderes ${ }^{179}$.

$176 \quad$ "Una tercera posibilidad, ausente a menudo en este debate extremadamente polarizado, es que los efectos de la judicialización sean en gran medida neutros" FERRAZ. Obra citada. p. 108.

177 "[...] el estado, al implementar políticas socioeconómicas y de salud con el fin de promover el derecho a la salud, debería tener como meta la reducción de las desigualdades entre sus ciudadanos en ese terreno. En un país tan desigual como el Brasil, esto implica, necesariamente, una fuerte preferencia por políticas que ejerzan impacto positivo en la salud de los más desfavorecidos. El impacto social de las resoluciones judiciales debe evaluarse en el mismo marco. Nuestra pregunta fundamental, por tanto, debería ser: ?La litigación en salud mejora las condiciones sanitarias de los más desfavorecidos?" FERRAZ. Obra citada. p. 110.

178 "Como evidência negativa, alguns estudos revelam que a maioria dos beneficiários dessas demandas são minorias privilegiadas”. CYRILLO, Denise C.; CAMPINO, Antônio Carlos C. Gastos com a saúde e a questão da judicialização da saúde. In: BLIACHERIENE, Ana Carla; SANTOS, José Sebastião [org.] 2010. p. 34.

179 WANG, Daniel Wei Liang. Poder Judiciário e participação democrática nas políticas de saúde. Dissertação de mestrado defendida no Programa de Pós Graduação em Direito da Universidade de São Paulo. 2009. p. 41. No mesmo sentido, ZUCCHI, Paola; VIEIRA, Fabiola Sulpino. Distorções causadas pelas ações judiciais à política de medicamentos no Brasil. In: Revista Saúde Pública. 2007; 41(2): 214-22: “A observação de que $63 \%$ dos impetrantes de ações judiciais residiam nas áreas do município com menor grau de exclusão social vai ao encontro do achado de que a maioria desses pacientes teve representação privada de seus processos. Também sugere que são indivíduos menos carentes de proteção social que estão movendo 
A falta de compreensão acerca da formação das políticas de saúde, especialmente quanto à assistência farmacêutica, acaba por gerar distorções evidentes no modelo desenhado para o SUS. Estudos e pesquisas indicam que dentre os medicamentos pleiteados judicialmente, muitos sequer possuem registro junto à Agência Nacional de Vigilância Sanitária (ANVISA) e outros tantos, embora registrados, são medicamentos novos de alto valor comercial, que por vezes encontram similares disponibilizados ou ainda não apresentam eficácia comprovada ${ }^{180}$.

Uma pesquisa realizada no Rio de Janeiro ${ }^{181}$, entre julho de 2007 e junho de 2008 apontou que o maior número de demandas relativas à concessão de medicamentos, movidas em face da Secretaria Estadual de Saúde, veiculava pedido de fornecimento de interferon peguilado e ribavirina (já que são administrados em associação), que já seriam distribuído aos pacientes com Hepatite $\mathrm{C}$ do genótipo 1. De acordo com os estudos apresentados na pesquisa, o interferon peguilado é recomendado apenas aos portadores da Hepatite $\mathrm{C}$ do genótipo 1 , já que os portadores dos genótipos 2 e 3 podem ser tratados com o interferon não peguilado ${ }^{182}$, que chega a ser trinta vezes mais barato.

No entanto, segundo indica a pesquisa, vários pacientes não têm em seus prontuários a descrição detalhada de sua condição patológica, o que pode indicar uma tentativa dos

ações contra o poder público municipal e instala a dúvida sobre o descumprimento das ações de equidade proposta pelo SUS".

${ }_{180}$ "Foram impetradas 170 ações contra a Secretaria requerendo o fornecimento de medicamentos. Os serviços do Sistema Único de Saúde originaram 59\% das prescrições (26\% municipais e 33\% os demais). Câncer e diabetes foram as doenças mais referidas (59\%). Faziam parte de listas de serviços $62 \%$ dos medicamentos solicitados itens solicitados. O gasto total foi de $\mathrm{R} \$ 876$ mil, efetuado somente para itens não selecionados (que não fazem parte da Relação Municipal de Medicamentos Essenciais), $73 \%$ dos quais poderiam ser substituídos. Do gasto total, $75 \%$ foram destinados à aquisição de antineoplásicos, cuja comprovação de eficácia necessita de mais ensaios clínicos." , ZUCCHI, Paola; VIEIRA, Fabiola Sulpino. Distorções causadas pelas ações judiciais à política de medicamentos no Brasil. In: Rev. Saúde Pública 2007; 41(2): 214-22.

181 FIGUEIREDO, Tatiana Aragão. Análise dos medicamentos fornecidos por mandado judicial na Comarca do Rio de Janeiro: A aplicação de evidências científicas no processo de tomada de decisão. Dissertação de mestrado. FIOCRUZ. Rio de Janeiro, 2010. p. 78.

${ }_{182}$ "para tratamento do vírus genótipo 1, ensaios clínicos demonstraram que os pacientes demonstraram respostas mais favoráveis ao interferon peguilado e ribavirina, visto que a resposta ao interferon não peguilado foi menos favorável, sendo necessário um tempo mais prolongado de terapia. Por outro lado, os pacientes infectados com vírus genótipo 2 ou 3 obtiveram respostas semelhantes utilizando interferon convencional ou interferon peguilado associados ou não à ribavirina (Lee et al, 2005; Xie et al, 2004 apud Pereira, 2006). Além disso, PCDT para Hepatite Viral Crônica C justifica a utilização do interferon peguilado em pacientes infectados com genótipo 1 baseada em ensaio clínico realizado por Manns et al (2001 apud MS, 2002) que não apresentou diferença estatística entre os tratamentos com interferon peguilado e interferon para os genótipos 2 e 3”. FIGUEIREDO. Obra citada. p. 79. 
médicos de facilitar a adesão dos indivíduos ao "Componente de dispensação de medicamentos excepcionais" $" 183$.

Ainda sobre os problemas causados pela indicação indiscriminada do interferon peguilado, Fabiola Sulpino Vieira ${ }^{184}$ aponta que $1 \%$ da população brasileira é portadora da Hepatite C, o que representaria em números absolutos pelo censo de 2006, 1.867 .706 (um milhão oitocentos e sessenta e sete mil setecentas e seis) pessoas. Caso o SUS tratasse $25 \%$ dessas pessoas (466.927), com o interferon peguilado na dosagem e tempo indicados (quarenta e oito semanas), o custo estimado seria de $\mathrm{R} \$ 24.800 .000 .000,00$ (vinte e quatro bilhões e oitocentos milhões de reais), o que representa $64 \%$ do gasto total executado pelo Ministério da Saúde no mesmo ano. "Ou seja, dois terços do orçamento federal da saúde seriam gastos para a oferta de um único produto farmacêutico com cobertura de $0,25 \%$ da população" ${ }^{185}$.

Como ficaria a situação dos orçamentos dos Estados e Municípios caso esses valores adviessem de demandas judiciais ajuizadas contra esses entes ${ }^{186}$ ? Não se trata de mera hipótese. Octávio Ferraz ${ }^{187}$ expôs em artigo anteriormente citado que o senador Tião Viana (PT/AC), um dos maiores críticos da judicialização da saúde no Brasil, chegou a mencionar que entre janeiro e outubro de 2009 foram gastos dois bilhões de reais para custeio de tratamentos impostos judicialmente a esferas diversas do governo. Assim, expõe Octávio Ferraz, se esses dados estiverem certos, a litigância nos níveis estadual e municipal excedeu em dezenove vezes o custo da litigância em face da União, tendo consumido cerca de oito por cento dos orçamentos destinados por esses entes à saúde.

\footnotetext{
183 FIGUEIREDO. Obra citada. p. 78.

184 VIEIRA, F. S. Ações judiciais e o direito à saúde: reflexão sobre a observância aos princípios do SUS. Revista de Saúde Pública, 42 (2), 2008.

${ }_{185}$ VIEIRA. Obra citada. p. 3. Sobre essa hipótese, dizem CYRILLO, Denise C.; CAMPINO, Antonio Carlos C. Obra citada. p.35: "O direito de $0,25 \%$ da população estaria garantido, mas e o direito dos restantes $99,75 \%$ ? Como fica o quesito equidade?".

186 "A dificuldade em organizar as finanças na área da saúde tem sido ainda agravada pela forte interferência do Poder Judiciário, com decisões determinando o fornecimento de medicamentos e tratamentos caros, exigindo esforço redobrado dos gestores para realocar recursos orçamentários, alterando a programação financeira dos entes federados. A judicialização da saúde é tema de tal relevância e interesse que motivou a realização de audiência pública no Supremo Tribunal Federal em 2009 para debater o tema [...]". CONTI, José Maurício. Saúde não precisa só de dinheiro, mas de boa gestão. http://www.conjur.com.br/2013-out-22/contas-vista-saude-nao-dinheiro-boa-gestao

187 FERRAZ. Obra citada. p. 105-6.
} 
Ainda que os números absolutos não sejam verdadeiros, assume Octávio Ferraz, a informação indica que a litigância cresce descontroladamente em face dos entes subnacionais e excede o fenômeno em nível federal ${ }^{188}$.

Como exemplo, trata da questão no estado de São Paulo, que no ano de 2008 gastou com demandas judiciais dessa natureza quatrocentos milhões de reais, o que representou cerca de $30 \%$ de seu orçamento destinado à compra de medicamentos e quase cinco vezes o valor gasto pela União no ano de 2009. No mesmo ano, o estado do Rio Grande do Sul gastou setenta e oito milhões de reais e Minas Gerais, quarenta milhões. Com base nos dados desses três estados apenas, constata-se que o gasto estadual em 2008 foi seis vezes maior do que o gasto da União em $2009^{189}$.

Viu-se que, o nível de comprometimento dos orçamentos dos entes subnacionais com gastos com direito à saúde importa em aumento no repasse de verbas pela União. Mas, o problema, aqui, passa pelos mecanismos de aquisição dos medicamentos. Quando um ente é responsável pela prestação de determinado serviço, ele consegue racionalizar os procedimentos burocráticos e fazê-los operar em seu favor. Agora, quando a responsabilização é imposta, de maneira difusa, a todos os três níveis da federação, de forma randômica - como acontece com as demandas individuais - os medicamentos passam a ser comprados unitariamente a preço cheio.

Embora se saiba que o problema existe e está posto no cotidiano das cortes brasileiras, a audiência pública realizada pelo STF não provocou alterações substantivas na jurisprudência dos tribunais, que continuam a decidir de forma ampla e irrestrita em favor dos litigantes, sem maiores considerações acerca da natureza do medicamento, da existência de substitutos e, tampouco, da responsabilidade de um determinado ente para execução e custeio do tratamento ${ }^{190}$.

\footnotetext{
188 "Si bien no parece claro en qué medida es precisa esa información, sin duda resulta evidente que la judicialización también crece sin control en los niveles estatal y municipal, y excede de manera significativa el fenómeno en el nivel federal, por los motivos ya mencionados. En efecto, incluso si tomamos en cuenta sólo algunos estados clave del Sur u el Sureste, donde el acceso a la información es más sencillo, ese escenario se confirma". FERRAZ. Obra citada. p. 105-6

$189 \quad$ FERRAZ. Obra citada. p. 106.

190 Falta ao Poder Judiciário a compreensão de que "uma boa gestão deste complexo sistema de saúde pública é evidentemente fundamental, pois, como já tenho repetido exaustivamente em várias colunas, mais do que dinheiro, o setor público precisa é de uma administração mais eficiente, o que exige estudos, planejamento e medidas não só de curto, mas também e principalmente de médio e longo prazos". CONTI,
} 


\title{
2.3. DIREITO À EDUCAÇÃO
}

A educação, assim como a saúde, possui verbas originariamente vinculadas pela Constituição como garantia de sua efetividade. Apesar disso, o direito à educação tem sofrido pelos desequilíbrios existentes entre as receitas públicas e as atribuições recebidas por cada ente federado ${ }^{191}$. Como aponta Salomão Barros Ximenes ${ }^{192}$ :

\begin{abstract}
tomamos em conta que é justamente no campo das políticas públicas educacionais onde mais foram experimentados, nos últimos anos, mecanismos redistributivos entre os entes federados, não sendo os mesmos, contudo, capazes de dar concretude aos princípios constitucionais da igualdade de oportunidades em matéria de ensino (art. 206, I) e da garantia de padrão mínimo de qualidade em todo o sistema (art. 206, IV), sobretudo em razão do afastamento da União de suas atribuições constitucionais "redistributiva e supletiva, de forma a garantir equalização de oportunidades educacionais e padrão mínimo de qualidade do ensino mediante assistência técnica e financeira aos Estados, ao Distrito Federal e aos Municípios (art. $211, \S 1^{\circ}$ )
\end{abstract}

Submetida a uma estrutura que funciona em regime colaborativo, a educação brasileira ainda possui pontos de penumbra, em que os entes federativos parecem ter mera faculdade de atuação, acarretando omissões sobrepostas em nome da cooperação que deveria existir $^{193}$.

José Maurício. Saúde não precisa só de dinheiro, mas de boa gestão. http://www.conjur.com.br/2013-out22/contas-vista-saude-nao-dinheiro-boa-gestao

191 A definição do regime republicano e da forma de organização federativa para o Estado brasileiro no Texto de 1988 suscita algumas questões relevantes para as políticas educacionais de acesso e de permanência na escola que definem a garantia e a efetividade do direito à educação: em que consiste o regime de colaboração na prestação dos serviços de educação pública? Como o princípio de igualdade de oportunidades, inerente ao direito à educação, se configura, levando em consideração o princípio da autonomia dos entes federados? Quais os impactos do processo de definição do regime de colaboração, a partir de 1996, para as desigualdades regionais na oferta do ensino fundamental? ARAÚJO, Gilda Cardoso de. Federalismo e direito à educação no Brasil: entre a autonomia e a igualdade de oportunidades. Disponível em:

https://www.google.com.br/url?sa=t\&rct=j\&q=\&esrc=s\&source=web\&cd=1\&ved=0CC0QFjAA\&url=http\% $3 \mathrm{~A} \% 2 \mathrm{~F} \% 2 \mathrm{~F} 26$ reuniao.anped.org.br\%2Fposteres\%2Fgildacardosoaraujo.rtf\&ei=wLbUUo2hFpTqkAfqpoG4 DA\&usg=AFQjCNECu7kj8YggfIwKHsvKlLqXkbN7mA\&sig2=gCRVsrxqcnHhaSyCCWC-Gw.

${ }_{192}$ XIMENES, Salomão Barros. Vinculação de recursos e desequilíbrios no financiamento da educação: potencialidades e limites da ação supletiva e redistributiva da União com o fim gradativo da DRU. In: CONTI, José Maurício et alli. [org.] 2010. p. 385.

193 "No caso da educação básica, temos uma torre de Babel, protegida sob o conceito politicamente conveniente de 'regime de colaboração'. Segundo esse conceito, as três instâncias da Federação podem operar (ou não) redes de ensino; podem financiar (ou não) a educação e podem escolher onde desejam (ou não) atuar. Resultado: não existe uma instância do poder público que seja responsável (e responsabilizável) pela oferta (ou não) de ensino fundamental aos munícipes. Cada instância faz o que pode e o que quer, supostamente em regime de colaboração". OLIVEIRA E ARAÚJO, João Batista. Avanços e impasses na educação: à guisa do balanço. p. 16-27, jan./mar. 1998. p. 24. 
O problema é exatamente o mesmo do direito à saúde, com a diferença que para este existe uma grande política única, o SUS, que engloba os três entes. Na educação, não existe um vetor principal que atue em direção única, porém descentralizada. Assim, cada ente fica responsável (ou não) pelo planejamento e execução das políticas que deveriam ser submetidas às suas responsabilidades.

A descentralização deve servir de princípio informador das políticas públicas nessas áreas. A disponibilidade de recursos e facilidade de execução de cada uma das tarefas devem ser avaliadas no momento de definição das responsabilidades de cada um dos níveis de governo, de forma a garantir a eficiência do serviço prestado e o atingimento do objetivo fundamental de redução das desigualdades regionais.

Essa é a ideia que surge da leitura conjunta do art. 23, V com o art. 211 da Constituição. A competência comum para proporcionar os meios de acesso ao direito à educação, por meio de um regime de colaboração, não deixa margem para uma construção de um sistema que seja, por exemplo, centralizado ou coordenado. Porém, pior do que acontece com a saúde, contemplada com a edição das Leis 8080/90 e 8142/90, a educação ainda não foi contemplada com a regulamentação das normas de cooperação entre os entes federativos.

Das poucas iniciativas adotadas em prol do estabelecimento de um regime de colaboração, todas vieram com feição de coordenação. Embora já dito que a União é que dispõe da competência legislativa para tratar de praticamente todos os assuntos submetidos à competência material comum, a existência de diálogo prévio é minguada no direito à educação, justamente por não existirem estruturas montadas como na saúde (Conselhos de Gestores).

Assim foi criado o Fundo Nacional de Desenvolvimento do Ensino Fundamental e Valorização do Magistério (FUNDEF). Veiculado por Emenda Constitucional (nº 14/96), dispôs sobre os mecanismo de financiamento da educação mediante redistribuição de receitas e relegou aos Estados e Municípios a definição das formas de colaboração em relação aos seus sistemas de ensino (art. $211, \S^{\circ}$ ). 
Além disso, trouxe ainda um conceito vago de prioridades a ser obedecida por cada um dos entes $^{194}$ que importou em certa confusão, pois colidente com as definições da Lei de Diretrizes e Bases (LDB). Deve-se admitir que após a edição dessa Emenda as posições jurídicas ficaram um pouco menos imprecisas ${ }^{195}$. Todavia, o problema do financiamento, alocação de recursos e equalização do padrão de ensino continuou a existir.

Ainda que estabelecido um piso mínimo de investimento, a prioridade do gasto por Estados e Municípios continuou a ser definida isoladamente por cada um desses entes, que, embora possa viabilizar melhor adaptação às realidades locais causou "elevação generalizada do gasto acompanhada de superposição e a dispersão das ações"196.

A atuação jurisdicional no controle das políticas públicas de educação é mais perceptível no nível infantil. As demandas submetidas ao Judiciário são sempre acolhidas com rigor imposto aos Municípios, a quem a Constituição impôs o dever de atuar prioritariamente nesse nível da educação.

Utilizando as chaves de busca "educação e infantil e responsabilidade e município" no site do STF em 15 de setembro de 2013, foram encontrados dois acórdãos da lavra do Ministro Celso de Mello ${ }^{197}$, nos quais fica muito clara a ideia de que, embora a educação infantil

\footnotetext{
194 "Nesse quadro de repartição de competências, cabe aos Estados e Municípios oferecer diretamente a educação básica (educação infantil, ensino fundamental e ensino médio) voltada às crianças e adolescentes, devendo a União federal exercer, em relação a este nível de ensino, "função distributiva e supletiva, de forma a garantir equalização de oportunidades educacionais e padrão mínimo de qualidade do ensino mediante assistência técnica e financeira aos Estados, Distrito Federal e aos Municípios". XIMENES. Obra citada. p. 392.

195 "A Emenda Constitucional n ${ }^{\circ} 14 / 96$ pode ser considerada o primeiro instrumento legal a tentar definir o regime de colaboração entre os entes federados. Todavia mesmo situando o papel suplementar da União, manteve a necessidade de explicitação das diretrizes que permitissem operacionalizar o regime de colaboração entre Estados e Municípios na oferta de ensino fundamental. A Emenda também modificou o Art. 60 do Ato das Disposições Constitucionais Transitórias reduzindo a participação da União na aplicação dos recursos vinculados constitucionalmente no ensino fundamental, ao mesmo tempo em que ampliava as responsabilidades das esferas estaduais e municipais com a criação do Fundo de Manutenção e Desenvolvimento do Ensino Fundamental e de Valorização do Magistério (FUNDEF). Enfim, A LDB (Lei de Diretrizes e Bases da Educação Nacional /Lei no 9394/96), também aprovada em 1996, consolidou o processo de definição do regime de colaboração no arranjo federativo esboçado em 1988. A Emenda e a LDB indicavam a possibilidade de superação dos impasses federativos quanto ao regime de colaboração, definindo Estados e Municípios como entes federados responsáveis pela oferta do ensino fundamental, etapa obrigatória de escolarização, e, principalmente, definindo critérios de gasto público com a educação que confrontavam a desorganização administrativa e fiscal do princípio de autonomia dos entes federados, visando soluções mais equânimes na distribuição de recursos e nas atribuições dos entes federados". ARAÚJO. Obra citada.

196 ARRETCHE. 2004.

197 BRASIL. Supremo Tribunal Federal. ARE 639337 AgR, Relator(a): Min. CELSO DE MELLO, Segunda Turma, julgado em 23/08/2011, DJe-177 DIVULG 14-09-2011 PUBLIC 15-09-2011 EMENT
} 
seja obrigação imposta constitucionalmente à generalidade do Poder Público, os Municípios não podem se demitir da obrigação de efetivá-la na íntegra.

A abordagem é bastante diversa da promovida no direito à saúde, tudo por conta a inserção do termo "prioritariamente" nos parágrafos $2^{\circ}$ e $3^{\circ}$ do art. 211 da Constituição. Inexplicavelmente, o Judiciário promove uma distinção entre a execução dos dois direitos, quando a Constituição não o faz. Ao que tudo indica, sintomas da importância que se dá ao direito posto sob análise e reflexo da "jurisprudência de misericórdia"198.

O STJ não discrepa desse entendimento. Na mesma data, utilizando as mesmas chaves de busca no site do STJ, foi encontrado o mesmo número de acórdãos: dois. No REsp 718203 / SP o Ministro Luiz Fux, com base em precedente do STF, decidiu pela legitimidade do Ministério Público para ajuizar ação civil pública em prol da defesa do direito dos menores à educação infantil. Já no julgamento do REsp 577573 / SP, o Ministro João Otávio de Noronha fez menção à questão orçamentária digna de nota. Em seu voto destacou:

\begin{abstract}
Exsurgiu nos autos questão atinente à possibilidade de superlotação das creches e a impossibilidade de o Município atender à demanda em face de restrições físicas e orçamentárias.

$[\ldots]$

A este argumento somam-se as razões expendidas pelo Desembargador Márcio Bonilha na decisão de suspensão da liminar (fls. 110/112) a respeito de inúmeras decisões determinando a matrícula de crianças em creches sem a aferição do mérito da questão (o que, in casu, foi superado) e da real capacidade que as instituições existentes têm de receber crianças além das vagas ordinárias, em razão da determinação do Poder Judiciário. Essa questão causa certa inquietação. Se, por um lado, entendo que não há sombra de dúvida acerca do dever do Município de assegurar tal ensino às crianças residentes em seus limites, por outro, é sobejamente sabido que a maioria dos municípios não presta tais serviços a contendo, muitos por desídia administrativa, mas, tantos outros, por restrições orçamentárias. No caso específico dos autos, não obstante tenha a municipalidade alegado falta de vagas e possível descumprimento da lei orçamentária, nada provou; a questão manteve-se no campo das possibilidades. Por certo que, em se tratando de caso concreto, no qual está envolvida apenas uma criança. isso não implicará superlotação de creche alguma. O Município deveria ter trazido aos autos a real situação em que se encontram seus estabelecimentos de ensino relativos à pré-escola, bem como a impossibilidade de se atender à demanda, em face de eventual extrapolação orçamentária, para que as instâncias ordinárias pudessem aferi-la frente ao que se postulou na presente ação.
\end{abstract}

VOL-02587-01 PP-00125; BRASIL. Supremo Tribunal Federal. RE 410715 AgR, Relator(a): Min. CELSO DE MELLO, Segunda Turma, julgado em 22/11/2005, DJ 03-02-2006 PP-00076 EMENT VOL-02219-08 PP-01529 RTJ VOL-00199-03 PP-01219 RIP v. 7, n. 35, 2006, p. 291-300 RMP n. 32, 2009, p. 279-290.

198 Termo utilizado na doutrina para definir as razões de deferimento de todo e qualquer pedido vinculado ao direito à saúde, por compaixão ou receio do juiz de determinar, indiretamente, a morte de um cidadão. 
Há claramente a admissão do argumento da reserva do possível, que deixou de ser apreciado por desídia do Município em fazer provas de suas restrições orçamentárias, o que poderia, no entanto, ser suprida por atuação do Magistrado da instância ordinária. A demonstração de existência ou não de fundos para custeio de um direito não pode ser encarada como mero dever do ente federativo, senão como interesse da coletividade.

É de interesse de todos saber e, porque não, controlar os orçamentos dos entes políticos. Nesse caso, se o Judiciário descobrisse que o Município em questão realmente não dispusesse de recursos para custear a vaga de creche pleiteada, não seria caso de apuração detalhada acerca dos motivos de inexistência da verba? Será que houve descontrole por parte do gestor ou os recursos seriam realmente ínfimos para satisfação do direito invocado?

No primeiro caso, o Judiciário poderia atuar controlando os orçamentos futuros do Município, evitando-se desperdício de verba que deveria ser investida em áreas prioritárias, como a educação. Já no segundo caso, será que o Judiciário apenas aceitaria a escusa justificada do Município e deixaria o setor educacional à míngua? Será que não existiria nenhum instrumento processual capaz de incluir na demanda, para resolução desse problema, outro ente responsável pela execução de políticas de educação, como o Estado ou mesmo a União, que é a grande responsável pelo financiamento das políticas públicas sociais?

Uma vez mais, a omissão deliberada do Judiciário põe em risco o bom desenvolvimento das políticas públicas sociais no Brasil.

\subsection{EFETIVAÇÃO DOS DIREITOS SOCIAIS E O PRINCÍPIO DA LEALDADE FEDERATIVA}

Se o relacionamento interfederativo brasileiro não padece de vícios, como a estrutura do pork $_{\text {barrel }}{ }^{199}$, é de fundamental importância que o sistema esteja sempre calibrado, de

199 "A origem de "Pork Barrel" remonta aos tempos da escravatura antes da Guerra Civil nos Estados Unidos da América, em que era dado um barril de "salt pork" aos escravos, fazendo com que estes competissem entre si por um quinhão desse porco conservado em sal. $\mathrm{Na}$ actualidade, este conceito de competição existe na política, no sentido em que, os políticos tentam garantir para si a maior quantidade de verbas disponíveis, para poderem satisfazer o seu eleitorado que por sua vez aumenta a probabilidade de 
forma a permitir maior adequação das transferências. Caso um determinado Município não tenha condições de arcar com os custos inerentes à atenção básica de seus munícipes, não é desejável que a União ou o Estado a que está vinculado territorialmente passe a fazer frente a essa despesa - exceto em caráter emergencial.

O sistema deve funcionar de maneira ajustada, de forma que o Município deve receber minimamente os valores necessários ao custeio dos direitos ditos indispensáveis - que entrem no critério de mínimo existencial. A solidariedade, tal como marcada pelo Poder Judiciário, favorece, ainda, a inércia do mau gestor, que fica livre de uma atuação pró-ativa e diligente, porque coberto pelo manto da solidariedade entre os entes. Essa solidariedade tem o poder de desestimular a boa atuação dos gestores públicos e perverter a estrutura do federalismo cooperativo, que é a perseguição de um fim comum - o interesse público com base na lealdade e convivência harmônica entre os agentes políticos ${ }^{200}$.

A solidariedade contida no pacto federativo não equivale à solidariedade obrigacional prevista no Código Civil. Ao tratarmos de solidariedade em uma federação a ideia que se tem é a de prestação de auxílio, de um ente a outro, para efetivação de um dever constitucional, não equivalendo à ideia de fungibilidade entre os responsáveis. Logo, a tese utilizada pelo Poder Judiciário além de violar o correto entendimento acerca da solidariedade ainda põe a perder o dever de lealdade ${ }^{201}$ entre os entes.

voltar a ser eleito (Ferejohn,1974). Apesar de ser um termo que teve origem nos Estados Unidos da América, é algo que é facilmente observável em qualquer parte do mundo [...]Na visão actual do conceito, Pork Barrel pode ser definido como uma estratégia eleitoralista assente em medidas que visam desenvolver ou beneficiar, do ponto de vista económico, uma determinada área ou espaço geográfico (região) sendo que, os custos destas medidas são imputados a todos os contribuintes do país. Nos Estados Unidos da América o termo "Políticas de Pork Barrel" é muito usado para definir aquelas medidas que são executadas pelos governantes com o intuito de originar retorno político, que por norma assume a forma de votos ou apoio político aos responsáveis pela existência daquela medida naquela região (McMenemy, 2001). Os gastos de Pork Barrel ou Pork Barrel spending é uma expressão que caracteriza aquilo que é o desperdício de recursos financeiros, na execução das medidas políticas oportunistas de Pork Barrel”. MOURAO, Paulo Reis; CUNHA, Eurico José A. Políticas Pork Barrel: um estudo sobre o caso português do PIDDAC. Disponível em: http://www.proppi.uff.br/revistaeconomica/sites/default/files/Politicas_Pork_Barrel_$\frac{1}{200}$ Um_estudo_sobre_o_caso_portugues_do_PIDDAC.pdf

"a existência de uma finalidade comum a todos os entes federativos, que justifica a sua agregação em um único Estado, ainda que organizado sob a forma de federação. O federalismo pressupõe, portanto, cooperação, lealdade e convivência harmônica entre as pessoas políticas que integram o Estado. Ainda que organizadas de maneira independente, elas dedicam-se à consecução do mesmo interesse público". MARQUES NETO, Floriano Azevedo. Parecer sobre o Projeto de Lei $\mathbf{n}^{\mathbf{0}}$ 3884/2004. Disponível em: Www.cidades.gov.br/media/ConsorcioPublico/ParecerFlorianoAzevedoMarquesNeto.pdf.

201 "[...] uma das características mais marcantes das Constituições Federais é a existência de um verdadeiro compromisso constitucional de cooperação, compromisso este que impõe deveres aos entes federados de atuarem com lealdade - i.e., não exercerem as suas competências de modo abusivo ou não prejudicarem os demais no exercício de suas competências - e solidariedade - i.e., prestarem auxílio quando 
O princípio da lealdade federativa ao tempo em que exige o apoio mútuo e recíproco entre os entes federados impõe a boa atuação de cada um, de forma a não permitir o desbalanceamento dos ônus previstos por lei ou pela Constituição. Impor diretamente à União um ônus que competiria a um Município apenas premia a má-gestão ${ }^{202}$ e a precarização do sistema de distribuição de rendas e não gera justiça social.

Vê-se, portanto, que a solidariedade a que se alude na discussão federativa está contida no princípio da lealdade federativa, que pode ser desmembrado analisado sob o ponto de vista ativo (solidariedade), que é quando os entes se unem para obtenção de um resultado comum, ou sob o ponto de vista passivo (fidelidade), que impede a adoção de práticas predatórias entre os entes da federação ${ }^{203}$.

Faz parte do papel desempenhado pelo princípio da lealdade federativa aliviar as tensões inerentes à estrutura do Estado Federal, como destaca Enoch Alberti Rovira ${ }^{204}$. Ainda de acordo com esse autor, o princípio da lealdade federativa constrói na relação entre os níveis da federação uma ética institucional que não tem somente caráter político e moral, mas igualmente jurídico ${ }^{205}$. Por força dessa ética de faceta jurídica, a lealdade federativa é exigível judicialmente ${ }^{206}$, seja em sua expressão ativa ou passiva.

A cobrança de fidelidade federativa não pode gerar, no entanto, um problema maior do que aquele que deu origem à sua exigibilidade judicial. Diogo de Figueiredo Moreira Neto assume que o tema tem complexidade evidente e acaba por gerar, na prática, "cumulações, superposições, contradições e conflitos, que suscitam, paralelamente aos problemas formais de definição e competência" ${ }^{207}$. Não por isso, o Judiciário pode ignorar ou

necessário ou desenvolverem atividade de forma conjunta e concertada na busca da concretização do interesse comum - para com os demais entes federados". KUBLISCKAS. Obra citada. p. 92.

202 "O princípio da lealdade federativa postula, basicamente, que as relações entre as distintas esferas de poder devem se inspirar na correção e boa fé, ou seja, no efetivo respeito das atribuições dos demais intervenientes". KUBLISCKAS. Obra citada. p. 129.

203 KUBLISCKAS. Obra citada. p. 95.

$204 \quad$ ROVIRA. Obra citada. p. 247.

205 ROVIRA. Obra citada. p.. 247.

206 "A exigibilidade judicial do princípio da lealdade federativa - haja visto a enorme jurisprudência formada a seu respeito tanto na Alemanha quanto em diversos países do mundo - parece inquestionável". KUBLISCKAS. Obra citada. p. 135.

207 MOREIRA NETO, Diogo de Figueiredo. A competência legislativa e executiva dos Municípios em matéria ambiental. In: Revista de Informação Legislativa. ano 28. nº111. jul/ set. 1991. Brasília: Senado federal, p. 123-138. 
desvirtuar a natureza de um instituto complexo, mas extremamente útil para resolução de problemas clássicos da estrutura federativa.

Se a solidariedade gera, por si só, cumulações e superposições, o que dizer de sua conjugação com uma estrutura de competências comuns destinada à resolução de problemas sensíveis - sob o ponto de vista político e econômico - como são os direitos sociais?

A divisão interna de competências e atribuições, ou como preferiu o constituinte, a fixação de normas de cooperação entre os entes da federação ficou a cargo de leis complementares vindouras, de acordo com o art. 23, parágrafo único da Constituição. Ocorre que, mesmo na existência dessas normas - como é o caso da saúde - o Judiciário consegue ignorá-las, preferindo a utilização equivocada do sentido do termo solidariedade.

Com isso, impõe aos entes federados a construção de estruturas replicadas, que possuem as mesmas funções, para que possam dar conta de atender às exigências impostas por mandamentos judiciais. Desnecessário dizer que os gastos aumentam exponencialmente sem que isso importe em melhoria na prestação do serviço exigido pela população ${ }^{208}$.

Todos os estudos formulados sobre o federalismo acabam por denunciar os mesmos problemas nesse ponto. A cooperação não pode ser subvertida, seja por dominação do ente central ou por criação de espaços de competência tão comuns que possam ser de todos ou de ninguém ${ }^{209}$.

Como estabelecido em voto singular proferido pelo Ministro Sepúlveda Pertence no julgamento da ADI 2544, "a inclusão de determinada função administrativa no âmbito de competência comum não impõe que cada tarefa compreendida no seu domínio, por menos

\footnotetext{
208 Essa situação faz com que haja "a duplicação de esforços e um aumento no custo dos serviços públicos, sem que necessariamente haja um aumento de eficiência". ABRÚCIO, Fernando. Descentralização - pacto federativo. Cadernos ENAP. n ${ }^{\circ}$ 1, 1993. p. 22.

"[...] no âmbito das competências para a realização de políticas públicas, tem-se consolidado o entendimento de que a principal forma de fomentar uma maior coordenação federativa é por meio de incentivos do poder central aos outros entes, para que atuem de forma cooperativa e não de forma competitiva, predatória ou errática. Com isso, tenta-se evitar tanto a superposição ineficiente de ações quanto a existência de espaços vazios, nos quais nenhum atua". SILVA, Luís Virgílio Afonso da. Federalismo e articulação de competências no Brasil. In: Guy Peters;Jon Pierre. (Org.). Administração pública: coletânea. Brasília/São Paulo: ENAP/UNESP, 2010, v. 1,p. 568.
} 
expressiva que seja, haja de ser objeto de ações simultâneas das três entidades federativas $[\ldots] "$

A ausência de prestação do serviço público gera completa frustração imediata do direito que se pretende fruir; por outro lado, a sobreposição de atuações importa em irracionalidade na utilização de recursos públicos com a consequente diminuição de verbas para realização de políticas públicas.

É preciso então, atentar-se ao princípio da conexão, de forma a estabelecer no ordenamento jurídico uma correlação simétrica entre a repartição de competências e a repartição de receitas $^{210}$, principalmente quando essas sejam objeto de reformas constantes e aquelas não. Já que a repartição de competências e receitas fica por conta do debate político, o Judiciário deve assumir para si, o dever de manter esse equilíbrio, a partir do princípio da lealdade federativa.

Ao tratar da aplicação do princípio da solidariedade pelo STF, Felipe de Melo Fonte foi muito feliz ao destacar apenas os exemplos adequados à demonstração da matéria. Segundo escreveu:

\begin{abstract}
Com base no dever jurídico de solidariedade a jurisprudência do Supremo Tribunal Federal já impôs limites à possibilidade de desmatamento de florestas no interior de propriedade privada, e declarou inconstitucional uma norma da Constituição do Estado do Rio de Janeiro que permitia aos servidores públicos legar pensões para beneficiários indiciados por eles quando inexistente cônjuge, companheiro ou dependente, exatamente porque isto onerava excessivamente os cofres públicos, em detrimento da coletividade. Há diversas decisões do STF afirmando ser aplicável o princípio da solidariedade nas questões que envolvem o sistema de previdência social, das quais se destaca a proferida por ocasião da instituição da contribuição previdenciária sobre as pensões e aposentadorias, na qual o argumento exerceu papel importante (275).
\end{abstract}

A solidariedade presente na estrutura federativa, como dito anteriormente, pressupõe a atuação de todos em uma área, por exemplo, a proteção do meio ambiente. Tomemos o exemplo dado pelo próprio autor: o STF impôs limites ao desmatamento de área inserida em propriedade privada, sob o argumento de que todos concorrem para a proteção desse direito. Importa dizer, portanto, que em caso de derramamento de petróleo por acidente em

\footnotetext{
210 "Jean Anastopoulos menciona ser imperioso o postulado de que a repartição de competências deva ser de forma semelhante à repartição das despesas, concluindo que a repartição dos encargos deve depender umbilicalmente da repartição de receitas públicas para o efetivo cumprimento dos desideratos locais e federais. Este é o chamado princípio da conexão". CARVALHO. Obra citada. p. 171.
} 
plataforma ou com navio cargueiro, em que o produto derramado atinja a costa e provoque prejuízos diretos (sejam os de ordem financeira ou sanitária) o particular, proprietário da área, deverá custear de seu bolso (diretamente, não considerando o pagamento de tributos) a limpeza do mar? A resposta óbvia é: não! Mas, por que não?

Porque a atuação de todos, ainda que solidária, é organizada em distintas esferas de competência. Do contrário, haveria uma infindável sobreposição de esforços e consequente dispêndio desnecessário de verbas para replicação de estruturas - que é o problema verificado, hoje, em relação à saúde.

Mas, em qual contexto o Ministro Celso de Mello, relator do MS 22.164-0 invocou o chamado princípio da solidariedade? Em seu voto de relatoria, referido princípio surgiu como qualidade atribuível aos chamados direitos fundamentais de terceira geração:

\begin{abstract}
O direito à integridade do meio ambiente - típico direito de terceira geração constitui prerrogativa jurídica de titularidade coletiva, refletindo, dentro do processo de afirmação dos direitos humanos, a expressão significativa de um poder atribuído, não ao indivíduo identificado em sua singularidade, mas, num sentido verdadeiramente mais abrangente, à própria coletividade social. Enquanto os direitos de primeira geração (direitos civis e políticos) - que compreendem as liberdades clássicas, negativas ou formais - realçam o princípio da liberdade e os direitos de segunda geração (direitos econômicos, sociais e culturais) - que se identificam com as liberdades positivas, reais ou concretas acentuam o princípio da igualdade, os direitos de terceira geração, que materializam poderes de titularidade coletiva atribuídos genericamente a todas as formações sociais consagram o princípio da solidariedade e constituem um momento importante no processo de desenvolvimento, expansão e reconhecimento dos direitos humanos, caracterizados, enquanto valores fundamentais indisponíveis, pela nota de uma essencial inexauribilidade. (MS 22164, Relator(a): Min. CELSO DE MELLO, Tribunal Pleno, julgado em 30/10/1995, DJ 17-11-1995 PP-39206 EMENT VOL-01809-05 PP-01155)
\end{abstract}

O voto analisado não revela a compreensão do Ministro acerca da extensão desse princípio da solidariedade sobre os direitos fundamentais, ou seja, se ele se restringe à categoria apresentada como direitos fundamentais de terceira geração ou se abrangeria todos os direitos fundamentais, independentemente da geração na qual tenha nascido.

O primeiro cenário conduz à conclusão de que os direitos sociais operariam com eficácia distinta, sendo os de primeira geração garantidores da liberdade, os de segunda geração da igualdade e somente os de terceira geração promoveriam a solidariedade. Embora a separação promovida no julgamento, de direitos fundamentais em gerações, conduza a esse 
entendimento, ele não se sustenta por duas razões: (i) a primeira, a ideia de gerações de direitos fundamentais (há muito ultrapassada) não contém em si a proposta de superação de uma geração pela outra, sendo sempre complementares; (ii) a segunda, a interpretação ampliada dos direitos fundamentais que não decorre de meros princípios doutrinários, mas está contida na própria Constituição $\left(\operatorname{art.} 5^{\circ}, \S \S 1^{\circ}\right.$ e $\left.2^{\mathrm{a}}\right)$.

Resta, pois, uma interpretação mais abrangente, que contemple a extensão do princípio da solidariedade a todos os direitos fundamentais, de forma a compor sua base axiológica. Então, os direitos sociais ${ }^{211}$ (ou econômicos, sociais e culturais ou de segunda geração) além de fomentarem a igualdade entre os indivíduos ainda seriam responsáveis pela garantia de liberdade e pela promoção da solidariedade. Somente a partir dessa leitura é que a igualdade passa a servir, concretamente, como técnica de efetivação e otimização dos direitos sociais ${ }^{212}$. Firmada essa primeira premissa, resta analisar a continuação da exposição de Felipe de Melo Fonte, que destacou:

\begin{abstract}
Ademais, segundo afirma a doutrina, o dever de solidariedade tem tido expressiva repercussão no campo da responsabilidade civil, ampliando as hipóteses de responsabilidade sem culpa. Em suma, o dever de solidariedade é um importante vetor jurídico, já que conforma os espaços de exercício legítimo dos direitos subjetivos, serve de importante argumento nas questões envolvendo seguridade social." (275-6).
\end{abstract}

Essa solidariedade, que decorre do art. $3^{\circ}$ da Constituição e se conjuga com os direitos fundamentais, seria a mesma prevista no Código Civil para as obrigações? Assim não parece.

Partindo do mesmo suporte doutrinário de Felipe de Melo Fonte ${ }^{213}$, é possível identificar que o princípio da solidariedade a que se refere o art. $3^{\circ}$ da Constituição é herança do Estado Social instalado no pós-guerras e responde pela virada interpretativa de um padrão

211 Em definição que expõe ainda melhor a íntima relação desses direitos com a solidariedade, Jorge Miranda os chama de "direitos de libertação de necessidade e expressão de solidariedade organizada". MIRANDA, Jorge. Manual de Direito Constitucional. Tomo IV. 4. ed. Coimbra: Coimbra Editora, 2008. p. 444.

212 CORREIA, Marcus Orione Gonçalves. Interpretação dos direitos fundamentais sociais, solidariedade e consciência de classe. In: CANOTILHO, J.J. Gomes. et alli [coord.] Direitos Fundamentais Sociais. São Paulo: Saraiva, 2010.

213 MORAES, Maria Celina Bodin de. O princípio da solidariedade. Disponível em: http://www.tepedino.adv.br/wp/wp-content/uploads/2012/09/biblioteca9.pdf. 
individualista para um coletivista. Trata-se de uma solidariedade social ${ }^{214}$, que responde, na linha de pensamento exposta anteriormente, pela igualdade como técnica de efetivação dos direitos sociais ${ }^{215}$.

Quer dizer, as políticas públicas sociais devem ser elaboradas e executadas com vistas à coletividade, ao atingimento daqueles objetivos traçados no art. $3^{\circ}$ da Constituição. Falar em solidariedade nesse contexto não tem nada a ver com solidariedade de obrigação, seja ela de dar, fazer, restituir ou pagar.

Assim como diversos outros institutos existentes no direito, a palavra solidariedade é expressão polissêmica e apresenta sentidos distintos dentro da própria dinâmica do Código Civil. Na matéria relativa aos contratos, ela importa em uma cooperação entre os contratantes, evitando-se comportamentos ambíguos ou eivados de má-fé. Já em relação às obrigações, a definição de solidariedade está descrita no art. 264 do Código Civil que dispõe:

Art. 264. Há solidariedade, quando na mesma obrigação concorre mais de um credor, ou mais de um devedor, cada um com um direito, ou obrigado, à dívida toda.

Com base em confusão entre os conceitos de solidariedade é que os Tribunais vêm aplicando a solidariedade obrigacional na efetivação dos direitos sociais. Verificada a pluralidade de devedores (entes federativos) e a obrigação de cada um perante toda a dívida (objeto do processo de controle de políticas públicas), o ente que tiver sido incluído pelo autor no polo passivo da demanda deverá arcar com a totalidade da dívida, pois compete ao credor escolher o devedor de quem cobrará (art. 275 do CC).

Mas, o mais curioso, é que o conceito ainda recebe ares de modernidade, com interpretação conforme do art. 283 do CC, que dispõe textualmente que:

\footnotetext{
214 Nos dizeres de Maria Celina Bodin de Moraes, “antes de ser princípio jurídico, a solidariedade é também virtude ético-teologal” BODIN. Obra citada. p. 5.

215 "Do ponto de vista jurídico, como mencionado, a solidariedade está contida no princípio geral instituído pela Constituição de 1988 para que, através dele, se alcance o objetivo da 'igual dignidade social'. O princípio constitucional da solidariedade identifica-se, assim, com o conjunto de instrumentos voltados a garantir uma existência digna, comum a todos, em uma sociedade que se desenvolva como livre e justa, sem excluídos ou marginalizados". BODIN. Obra citada. p. 8.
} 
Art. 283. O devedor que satisfaz a dívida por inteiro tem direito a exigir de cada um dos co-devedores a sua quota, dividindo-se igualmente por todos a do insolvente, se o houver, presumindo-se iguais, no débito, as partes de todos os co-devedores.

Isso não serve para os entes federativos. Os Tribunais entendem que como todos são responsáveis pelo financiamento e execução de todas as políticas públicas sociais que possam vir a ser questionadas em juízo, somente o ente que tiver sido expressamente indicado na petição inicial, ou seja, somente aquele que foi indicado pelo autor para responder perante o Poder Judiciário pela omissão da execução de determinada política pública, será responsável por seu custeio e execução, não podendo valer-se de ação de regresso contra algum dos demais.

Vê-se, portanto, que a condenação de um ente por outro tem por base a confusão conceitual acerca do termo solidariedade. Se o princípio inscrito no art. $3^{\circ}$ da Constituição importa em uma visão mais social do ordenamento jurídico, servindo de baliza interpretativa para todo o ordenamento, a solidariedade deduzida - e não declarada - nos arts. 23, 196, 198 e 205 da Constituição decorre do princípio da lealdade federativa e importa em pré-autorização cooperativa entre os entes federativos.

O destaque à inexistência de declaração de solidariedade nos artigos da Constituição decorre da previsão contida no artigo 265, do CC/2002, que apresenta máxima antiga do direito civil, a saber:

Art. 265. A solidariedade não se presume; resulta da lei ou da vontade das partes.

A solidariedade do art. 265, como já dito, tem a ver com os direitos e deveres obrigacionais e, por todas as razões expostas, não se confunde com as solidariedades decorrentes da Constituição.

A atuação do particular se dá mediante pagamento de tributos. Isso justifica a autorização de sua exclusão. Mas, o mesmo, deve servir aos entes federados, que financiam as políticas públicas - tratando das voltadas para atendimento dos direitos à saúde e à educação mediante destinação de verbas (as chamadas verbas carimbadas), que decorrem de compromissos previamente fixados pelo texto constitucional, ou, como explicado por 
André Castro Carvalho, de despesas obrigatórias ${ }^{216}$. É aqui, na disposição constitucional que versa sobre as despesas obrigatórias que se encontram os entes federados, para formação de fundos financeiros que suportem o custeio das mais diversas políticas públicas previstas, igualmente, pela Constituição e não para execução direta de cada uma dessas políticas.

Apresentadas essas premissas, é preciso trazer os mecanismos pelos quais o Poder Judiciário poderia contribuir com o aperfeiçoamento do federalismo de maneira a fortalecer o planejamento e a execução das políticas públicas sociais no Brasil.

\subsection{O ANTEPROJETO DO CEBEPEJ}

O Anteprojeto elaborado a partir da pesquisa do CEBEPEJ conta com trinta e um artigos que dispõem sobre: (i) princípios aplicáveis ao controle jurisdicional de políticas públicas; (ii) regras sobre competência e petição inicial; (iii) fase administrativa; (iv) meios alternativos de solução de controvérsias; (v) procedimento aplicável ao processo judicial; (vi) método de reunião dos processo em primeiro grau de jurisdição; (vii) relação entre magistrados com competência para julgamento dessas ações; (viii) reunião dos processos em grau recursal; (ix) formação de cadastro nacional de processos; (x) as demandas individuais, e; (xi) disposições finais.

Vê-se que toda a estrutura é pensada com vistas ao diálogo entre os agentes públicos e a sociedade. A previsão de fase administrativa e de meios alternativos de solução de controvérsia como forma de evitar-se uma decisão impositiva do Judiciário é uma contribuição de enormes proporções para a matéria, já que um dos grandes problemas havidos nessa área é, justamente, o receio de substituição de decisões técnico-políticas por decisões jurídicas.

\footnotetext{
216 "Apesar de comumente haver a utilização das expressões despesa ou gasto mínimo obrigatório, o texto constitucional utiliza o conceito, impropriamente, como sinônimo de vinculação, como ocorreu com a saúde e educação nas suas respectivas emendas constitucionais. Pode-se depreender isto até mesmo da nomenclatura usada na Constituição Federal, mormente no art. 198, §3º , II [...] há, em nossa opinião, um critério diferencial que separa vinculação de receita de despesas obrigatórias. O fato preponderante é, justamente, a obrigatoriedade no gasto. A despesa obrigatória, conforme o próprio nome diz, obriga ao gasto no exercício financeiro, diferentemente da vinculação. Esta, por outro lado, apenas estabelece um elo normativo entre uma fonte e destino". CARVALHO, André Castro. Vinculação de Receitas Públicas. São Paulo: Quartier Latin, 2010 (b). pp. 119-120.
} 
Ao Magistrado é dada participação nos dados financeiros e orçamentários da Fazenda Pública demandada, nas ações e iniciativas já previstas em orçamentos anteriores ou em planejamento estratégicos, de forma que sua decisão passa a ter maior aderência à realidade fática.

A preocupação com o estabelecimento de critérios técnicos é visível na previsão do parágrafo $3^{\circ}$ do art.5 $5^{\circ}$ na prestação de informações, a autoridade responsável pela execução da política pública poderá servir-se de assessores técnicos especializados", do parágrafo $4^{\circ}$ do mesmo artigo "o juiz poderá nomear técnicos especializados para assessorá-lo na análise das informações, sem prejuízo de consultas a órgãos e instituições do ramo", no art. $7^{\circ}$, caput, "tendo por esclarecidas as questões suscitadas na fase administrativa, o juiz poderá designar audiências públicas, convocando representantes da sociedade civil e de instituições e órgãos especializados." e parágrafo único "admite-se, tanto na fase administrativa como no processo judicial, a intervenção do "amicus curiae", pessoa física ou jurídica, que poderá manifestar-se por escrito ou oralmente." e na do art. 17 "para o efetivo cumprimento da sentença ou da decisão antecipatória, o juiz, independentemente das medidas previstas no art. 15, poderá nomear comissário, pertencente ou não à Administração, que também poderá ser pessoa jurídica, para a implementação e acompanhamento das medidas necessárias à satisfação das obrigações, informando ao juiz, que poderá lhe solicitar quaisquer providências".

A celeridade é outro fator que ganha enorme destaque, nas previsões do art. $6^{\circ}$ "se o pedido envolver o mínimo existencial ou o bem da vida assegurado em norma constitucional de maneira completa e acabada, o juiz poderá antecipar a tutela, nos termos do art. 273 do Código de Processo Civil, ficando nesses casos dispensadas as informações a respeito dos incisos II, III e IV do art. 5", do art. 13 "não havendo acordo, o juiz examinará, no juízo de admissibilidade, a razoabilidade do pedido e a irrazoabilidade da atuação da Administração, podendo extinguir o processo, com resolução do mérito, ou determinar a citação do representante judicial da autoridade competente, para responder.", do art. 15 "todos os elementos probatórios colhidos na fase preliminar, em contraditório, serão aproveitados no processo judicial, devendo o juiz privilegiar o julgamento antecipado da lide, sempre que possível." e do art. 16 "o prazo para contestar será de 30 (trinta) dias, sem outros benefícios de prazo para a Fazenda Pública, seguindo o processo o rito ordinário previsto no Código de Processo Civil". 
Fora isso, as previsões de reunião dos processos em primeiro grau de jurisdição ou em grau recursal, além da previsão de encontros periódicos com os Magistrados que tenham competência para julgar processos semelhantes conferem à disciplina grande estabilidade prática (jurisdicional), o que não se vê em nenhum outro procedimento disposto no ordenamento jurídico brasileiro.

Embora o anteprojeto exiba redação irretocável, contenha os pontos centrais da discussão e disponha sobre um processo mais adequado ao controle de políticas públicas, ele não dispõe de mecanismos para controle da legitimidade passiva pensados a partir da responsabilidade de cada um dos entes federados.

Já que a pretensão é abrir grandes espaços de diálogo e compreensão que permitam ao Judiciário uma atuação mais segura e coerente com a dinâmica das políticas públicas sociais, é fundamental que se possa permitir a atuação dos agentes mais apropriados à discussão do direito veiculado em cada processo.

Como poderia a União participar de um processo em que se discutam problemas relacionados à atenção básica da população de um determinado município ou falta de vagas em escolas para crianças de 4 a 6 anos de idade dessa mesma localidade? Quais seriam os dados que ela poderia fornecer? De que serviria ao Judiciário conhecer seu orçamento?

Da mesma forma, com determinar que um Município integre um processo cujo objeto seja a prestação de um medicamento de alto custo, que a União possa fornecer a preço módico porque o produz em seus laboratórios?

Não se defende a prevalência de questões processuais em detrimento de um direito fundamental nem, tampouco, que estes sejam desimportantes frente a questões orçamentárias. Pelo contrário, a busca é pela adequação do processo à construção das leis orçamentárias de forma a proporcionar maior efetividade aos direitos fundamentais. Assim, é necessário passar em revista os institutos processuais inerentes à discussão do presente tema, como os conceitos de parte, terceiros e espécies de intervenção. 
De tudo quanto dito, a premissa da qual partimos é a seguinte: não existe no ordenamento jurídico regra, constitucional ou legal, que crie solidariedade obrigacional entre os entes federativos para execução de todas as etapas das políticas públicas destinadas à efetivação dos direitos fundamentais à saúde e à educação.

A solidariedade encontrada na Constituição deriva ou da cláusula geral de interpretação do art. $3^{\circ}$ ou do princípio da lealdade federativa (que pré-autoriza a coordenação de forças para atingimento de um fim comum) e aporta como regra não expressa na responsabilidade de custeio dessas políticas, mediante criação de fundos.

O problema denunciado nesse trabalho não é a correta, devida ou suficiente observância das normas inscritas, e.g., nos artigos 196, §2º I, II e III; §3º, I, II, III e IV, da Constituição e na Lei Complementar 141/2012 (critérios de financiamento da saúde) e nos artigos 213 parágrafos e 214 parágrafos. O descumprimento da aplicação de recursos previstos nos artigos mencionados devem ser resolvidos por mecanismos de responsabilização dos agentes públicos, mediante ações de apuração de responsabilidade civil, administrativa e criminal.

A questão, aqui, passa pelas reclamações dos cidadãos, que chegam ao Judiciário pela via de ações individuais ou coletivas, acerca da falta de tratamentos adequados à prevenção e combate de doenças e outros agravos (termo utilizado pelo art. 196 da Constituição) e da não disponibilização de vagas em creches e escolas públicas e gratuitas.

O Judiciário tem recebido essas demandas independentemente do ente que seja demandado pelo cidadão, sob o argumento aqui denunciado da solidariedade para promoção de saúde e educação. No entanto, a Constituição apenas determina conjunção de esforços em relação à montagem de fundos para custeio desses direitos, jamais apontando a existência de solidariedade em relação à execução das políticas públicas sociais.

A clareza da independência dessas obrigações (custeio e execução) advém da própria jurisprudência do STJ - quando do julgamento de processos cujo objeto é o fornecimento de medicamentos - que recusa a admissibilidade do chamamento ao processo por ser figura processual típica das obrigações solidárias de pagar quantia e "não comporta interpretação 
extensiva para alcançar prestação de entrega de coisa certa, cuja satisfação efetiva inadmite divisão" 217 .

Se a obrigação não é de pagar e sim de entregar coisa, então a solidariedade não pode ser extraída da responsabilidade pelo custeio, mas sim pela execução direta da política pública, razão pela qual a parte legitimada para figurar em processos de controle de políticas públicas é aquela a quem foi atribuída responsabilidade pela concretização da política e não por seu financiamento.

Não há solidariedade prevista para a execução de grande parte das políticas sociais; antes, alguns entes são previamente incumbidos de tarefas distintas. Logo, os entes não responsáveis pela execução de determinadas políticas públicas seriam ilegítimos para figurar no polo passivo de demanda que veicula esse tipo de pedido.

A ilegitimidade de uma das partes conduz, segundo dispõe o art. 267, VI do CPC, à extinção da demanda sem resolução do mérito. Ou seja, o processo ajuizado em face do ente não responsável pela satisfação da tutela pleiteada deveria, pelas regras processuais, ser extinto sem a entrega do bem da vida solicitado pelo cidadão. A primeira questão a ser respondida é, portanto: como deve ser o processo para realização do controle jurisdicional de políticas públicas?

\footnotetext{
217 Dentre todos, o mais recente: BRASIL. Superior Tribunal de Justiça. AgRg no REsp 1281020/DF, Rel. Ministro HERMAN BENJAMIN, SEGUNDA TURMA, julgado em 23/10/2012, DJe 31/10/2012; AgRg no REsp 1076592/PE, Rel. Ministro CESAR ASFOR ROCHA, SEGUNDA TURMA, julgado em 29/05/2012, DJe 13/06/2012.

A realização de busca no site do STJ com a chave de busca "chamamento e processo e fornecimento e medicamento" gerou, em 15.08.2013 um resultado de 32 acórdãos, dos quais 21 veiculam tese semelhante. Os demais 11 foram descartados por abordarem somente questões processuais (conflitos de competência e inadmissibilidade recursal).
} 


\section{O PROCESSO E O CONTROLE JURISDICIONAL DE POLÍTICAS PÚBLICAS}

"Processo civil é, resumidamente, técnica de solução imperativa de conflitos"218. Com essa frase clara e direta, Cândido Rangel Dinamarco inaugura suas Instituições com indicação de um caminho mais simples para compreensão da matéria. Após trilhar um percurso de grandes mudanças conceituais, o processo ainda não conseguiu encontrar uma identidade reconhecida por todos. Há quem diga que existam tantos conceitos de processo quanto autores de livros sobre o tema. Ninguém nega, porém, a verdade contida na frase de abertura desse parágrafo.

No Brasil, as definições que gozam de maior prestígio e aplicação são: (i) processo como relação jurídica processual e; (ii) processo como procedimento em contraditório ${ }^{219}$.

Responsável pelo desenvolvimento da teoria dos pressupostos processuais, Oskar von Bülow identificou a natureza de relação jurídica processual do processo, diferenciando-o, definitivamente, da relação jurídica material por ele conduzida ao Judiciário. O processo anteriormente tinha caráter suplementar ao direito civil, desprovido de metodologia, princípios e características próprias. O rompimento dessa relação de dependência ocorreu após a conhecida polêmica entre Windscheid e Muther.

A estrutura de relação jurídica de Bülow difere da relação jurídica material em relação aos sujeitos (categoria que compreende autor, réu e juiz), ao objeto (no processo a ideia está vinculada com as tutelas ou provimentos) e a presença dos pressupostos processuais de existência e validade ${ }^{220}$, sobre os quais recai a maioria das críticas atuais acerca do conceito.

218 DINAMARCO, Cândido Rangel. Instituições de Direito Processual Civil. vol. I. 6. ed. rev. atual. São Paulo: Malheiros, 2009 p. 37.

219 Outras teorias bastante relevantes, mas que não serão tratadas nesse trabalho são: (i) processo como situação jurídica (Goldschmidt); (ii) processo como instituição (Jaime Guasp); (iii) processo como entidade jurídica complexa (Foschini); (iv) doutrina ontológica do processo (João Mendes Júnior); processo como método argumentativo de resolução de controvérsias (Samuel Meira Brasil Jr.).

${ }_{220} 20$ Brasil, todavia, predomina a denominada 'corrente ampliativa'. Os pressupostos processuais seriam os requisitos de existência e desenvolvimento válido e regular do processo. Dividem-se em subjetivos e objetivos [...] Há quem classifique os requisitos de natureza processual em três espécies. A primeira é composta daqueles essenciais à própria existência do fenômeno processual. Os pressupostos processuais propriamente ditos seriam os necessários não ao nascimento, mas ao desenvolvimento da relação, cuja ausência leva à extinção do processo sem julgamento do mérito. Além deles, também haveria os requisitos de validade relacionados exclusivamente a um ou mais atos processuais. $O$ não-preenchimento destes 
A concentração do processo em aspectos formais e burocráticos tenderia a afastá-lo de seu objetivo primordial, que é a criação de um espaço de diálogo (que não se confunde com consenso) entre as partes processuais que possa servir de sustentação à decisão estatal para solução da crise de direito posta ao crivo do Judiciário.

Nisso, supostamente, difere o conceito apresentado por Elio Fazzalari. A estrutura fazzalariana do processo compreende a prática de uma série de atos (situação legitimada) ao longo do processo por cada um de seus protagonistas - categoria na qual inclui o juiz e seus auxiliares $^{221}$. Logo, em decorrência dos sujeitos que estão autorizados a praticá-los (situação legitimante) esses atos podem ser aqueles submetidos ao contraditório ou os relativos ao exercício da função estatal, pelo juiz ou por seus auxiliares. A concatenação desses atos praticados sob o contraditório é o que se pode denominar processo ou módulo processual $^{222}$.

O procedimento sem contraditório, para Fazzalari, não é processo ${ }^{223}$. A ideia de Fazzalari nunca foi, porém, a de substituir ou alterar a concatenação dos atos processuais; para ele a questão sempre foi diminuir a fisionomia de procedimento e conduzi-la para o contraditório $^{224}$. Tem-se, portanto, que a diferença básica existente entre as concepções apresentadas seria o foco colocado nos aspectos formais (relação jurídica processual) ou na interação entre os sujeitos do processo (procedimento em contraditório).

comprometeria apenas o ato defeituoso, não o processo como um todo". BEDAQUE. Efetividade do processo e técnica processual. São Paulo: Malheiros, 2006a. pp. 187-8.

221 'L'impiego della struttura del 'processo' consente, anzi impone, di ordinare uno schema comprensivo tutti gli atti leciti e/o doverosi facenti capo a ciascuno dei protagonisti (giudice, ausiliari, parti), lungo il corso del processo. Tale serie di atti costituisce, infatti, il contenuto della di lui 'legittimazione ad agire', la situazione legittimata di ciascuno" FAZZALARI, Elio. Istituzioni di Diritto Processuale. VIII ed. Padova: CEDAM, 1996. p. 422.

222 'L'ordine che si determina per la successione e mutua implicazione degli atti dei vari protagonisti (di una parte, dell'altra, del giudice, dell'ausiliare ecc.) costituisce appunto il 'processo'”. FAZZALARI. Obra citada p. 422.

223 "[...] il processo è un procedimento in cui partecipano (sono abilitati a partecipare) coloro nella cui sfera giuridica l'atto finale è destinato a svolgere effetti: in contraddittorio, e in modo che l'autore dell'atto non possa obliterare le loro attività. Non basta, per distinguere il processo dal procedimento, il rilievo che nel processo vi è la partecipazione di più soggetti, che cioè gli atti che lo costituiscono sono posti in essere non dal solo autore dell'atto finale, ma anche da altri soggetti. [...] Occorre qualche cosa di più e di diverso; qualche cosa che l'osservazione degli archetipi del processo consente di cogliere. Ed à la struttura dialettica del procedimento, cioè appunto, il contraddittorio". FAZZALARI. Obra citada. pp. 82-3.

224 "Perciò fino a ieri - e talvolta ancora oggi - la caratteristica própria del 'processo' - il contraddittorio - non è stata colta da tutti i processualisti e giuspubblicisti, e il processo è stato per lo più assorbito nella generica fisionomia del procedimento. Ieri soltanto il 'processo' ha rinvenuto un proprio significato (significato distinto, ma non disgiunto dalla nozione di procedimento: solo un passo più innanzi) e si è dispiegato in tutta la sua potenzialità d'impiego". FAZZALARI. Obra citada. p. 76 
Dessa estrutura, nota-se que a definição do processo enquanto procedimento em contraditório não impede nem conflita com a ideia de relação jurídica processual. Isso porque, exercício do contraditório apenas qualifica o procedimento, não sendo capaz de responder pela força centrípeta que une as partes processuais. Essa força é justamente a relação jurídica processual ${ }^{225}$.

Pela relação jurídica processual as partes se relacionam com o Estado mediante a prática de atos obrigatórios ou facultativos (poderes, direitos e faculdades e seus equivalentes, deveres, obrigações, sujeições e ônus), ou seja, é ela a responsável pela garantia da cooperação entre as partes envolvidas na crise do direito conduzida ao processo, como forma de atingimento do objetivo comum, que é o fim do litígio ${ }^{226}$. Haveria, pelas definições apresentadas, diferença substancial entre as concepções de processo enquanto relação jurídica material e procedimento em contraditório? De acordo com Grinover ${ }^{227}$, Dinamarco e Cintra, não. Para eles:

[...] a presença da relação jurídico-processual no processo é a projeção jurídica e instrumentação técnica da exigência político-constitucional do contraditório. Terem as partes poderes e faculdades no processo, ao lado de deveres, ônus e sujeição, significa, de um lado, estarem envolvidas numa relação jurídica; de outro, significa que o processo é realizado em contraditório. Não há qualquer incompatibilidade entre essas duas facetas da mesma realidade; o que ficou dito [...] (direitos e garantias constitucionais como sinal da exigência de que o processo contenha uma relação jurídica entre seus sujeitos) é a confirmação de que os preceitos político-liberais ditados a nível constitucional necessitam de instrumentação jurídica na técnica do processo.

É lícito dizer, pois, que o processo é o procedimento realizado mediante o desenvolvimento da relação entre seus sujeitos, presente o contraditório. Ao garantir a observância do contraditório a todos os 'litigantes em processo judicial ou administrativo e aos acusados em geral', está a Constituição (art. $5^{\circ}$, inc. LV) formulando a solene exigência política de que a preparação de sentenças e demais provimentos estatais se faça mediante o desenvolvimento da relação

225 GRINOVER, Ada Pellegrini; DINAMARCO, Cândido Rangel; CINTRA, Antônio Carlos de Araújo. Teoria Geral do Processo. 19.ed. 2003. p. 277.

226 GRINOVER, Ada Pellegrini; DINAMARCO, Cândido Rangel; CINTRA, Antônio Carlos de Araújo. Obra citada. p. 282.

227 Há tempos, Ada Pellegrini Grinover já deixava antever seu posicionamento sobre a importância do contraditório na estrutura do processo. Em escritos anteriores, afirmou que "se de um lado o processo não será um verdadeiro processo enquanto não proteger as partes, no sentido de lhes dar oportunidade de sustentarem suas razões, de produzirem sua defesa, de apresentarem suas provas, de influírem sobre a formação do convencimento do juiz, de outro lado a resposta jurisdicional, por sua vez, não será legítima, nem será resposta jurisdicional, enquanto não representar o coroamento de um processo que obedeça a essas garantias. [...] se o fundamento lógico do contraditório é a própria defesa, porque não poderá haver aquele enquanto esta inexistir; se, ademais, o fundamento constitucional do contraditório e da defesa é o próprio princípio da igualdade, que compreende a igualdade processual, temos então defesa e contraditório garantidos, ambos, para qualquer processo, pela Constituição do Brasil, como decorrência da igualdade processual". GRINOVER, Ada Pellegrini. O princípio da ampla defesa no processo civil, penal e administrativo. In: O processo em sua unidade - II. Rio de Janeiro: Forense, 1984. pp. 60-2. 
jurídica processual. GRINOVER, Ada Pellegrini; DINAMARCO, Cândido Rangel; CINTRA, Antônio Carlos de Araújo. Teoria Geral do Processo. 19 ed. São Paulo: Malheiros, 2003. P. 285.

O contraditório, embora estudado com especial atenção no primeiro pós-guerra, não mereceu atenção central, tendo permanecido na órbita do conceito de procedimento ${ }^{228}$. No segundo pós-guerra, ele começa a receber maior atenção e a ser destacado, especialmente por Elio Fazzalari, como característica central do processo ${ }^{229}$.

No entanto, fazendo coro às palavras de Grinover, Dinamarco e Cintra, Nicola Picardi afirma, com base na teoria de Merkl, que o direito processual é constituído por todos os elementos do ordenamento jurídico geral que regulam a via de produção dos atos jurídicos com base em outros atos jurídicos - que seriam as normas legais. Por essa razão, o contraditório, porque previsto normativamente, integra a estrutura do processo, mas não representa uma necessidade imanente, porque não está relacionado diretamente ao momento principal do julgamento. A sua função se esgota na garantia de paridade de armas conferida às partes, através de uma dinâmica de contraposição de teses e, no limite, em um instrumento de disputa ${ }^{230}$.

Seja porque fundamento principal do processo ou derivado de previsão constitucional acerca das garantias inerentes ao instrumento, o contraditório não pode ser afastado de sua estrutura sem risco de invalidade do julgamento ${ }^{231}$. A opção feita no momento é por um processo como relação jurídica processual animada pelas garantias constitucionais - dentre elas, o contraditório ${ }^{232}$.

228 "Per cogliere a pieno questo mutamento di prospettiva, sarà utile ricordare che nel primo dopoguerra, sotto l'influsso della teoria normativa del diritto, ha finito per prevalere la ricostruzione del processo sub specie di procedimento. È noto come l'applicazione di tale nozione abbia consentito una ricostruzione più rigorosa della normativa del processo $\mathrm{e}$, in particolare, uno studio più attento dell'atto processuale. Peraltro, nell'ambito di questa concezione, il contraddittorio è rimasto, in qualche modo, ai margini del fenomeno processuale". PICARDI, Nicola. Il principio del contraddittorio. In: Rivista di Diritto Processuale. Padova: CEDAM. p. 675.

$229 \quad$ PICARDI. Obra citada. p. 676.

$230 \quad$ PICARDI. Obra citada. p. 679).

231 Trata-se de risco e não de certeza. É possível que haja aproveitamento do processo conduzido sem observância do contraditório, segundo proposições apresentadas por BRASIL JR., Samuel Meira. Processo como método argumentativo de resolução das controvérsias. In: Justiça, Direito e Processo... São Paulo: Atlas, 2007. pp. 43-7.

232 "[...] por garantia se entende o instrumento assecuratório dos direitos, assim declarados. As garantias são instrumentais em relação aos direitos: tanto assim que se pode falar no mandado de segurança e no habeas corpus como sendo garantias, na medida em que servem instrumentalmente para assegurar os direitos declarados. Por vezes, um direito é ao mesmo tempo garantia de proteção de outros direitos. Assim é para o direito de defesa, em si mesmo declaratório, mas concomitantemente garantia para a efetivação de 
Desse breve histórico traçado, é possível observar que o processo teve alternâncias de compreensões e significados, ora dispensando o contraditório ora o trazendo para seu núcleo central; assim, também, o processo já foi relação jurídica processual, situação jurídica, procedimento em contraditório e muitas coisas mais.

Em tempos mais recentes, grandes aportes teóricos foram feitos para conduzir o processo a um patamar mais elevado, saindo das legislações ordinárias e rumando para a altivez das disposições constitucionais $^{233}$. Construções teóricas importantíssimas para os objetivos desse trabalho, como de Cândido Rangel Dinamarco ${ }^{234}$, José Roberto dos Santos Bedaque $^{235}$ e Samuel Meira Brasil Jr. ${ }^{236}$ foram capazes de abrir uma fenda no eterno espelho onde o processo apenas se vê, de forma narcisista.

Apesar disso, há, talvez, somente um trabalho de maior fôlego sobre a necessidade de adaptação dos procedimentos às mais diversas relações materiais nele veiculadas ${ }^{237}$. O conceito de processo sofreu ajustes aqui e acolá, mas nada significante sob o ponto de vista da preparação desse instrumento para melhor receber diferentes tipos de litígio ${ }^{238}$.

A uniformidade procedimental, inclusive, já foi denunciada por Luiz Guilherme Marinoni, como uma "tentativa de eliminar a influência do direito material sobre o direito processual" 239 . Obviamente que, para ele, é preciso que haja adaptabilidade do

outros direitos. Realmente, o direito de defesa pode viabilizar o direito ao processo, pode garantir o direito ao contraditório, pode tutelar até o direito de ir e vir, ou seja, a liberdade pessoa. Por sua vez, o direito de defesa tem suas garantias". GRINOVER. 1984. pp. 56-7.

233 Dentre todos: GRINOVER, Ada Pellegrini. A garantia Constitucional do direito de ação e sua relevância no processo civil. São Paulo, 1972.

234 DINAMARCO, Cândido Rangel. A instrumentalidade do processo.11. ed. São Paulo: Malheiros, 2003.

235 BEDAQUE, 2006a.

236 BRASIL JR. Obra citada. 2007.

237 Trata-se do cuidadoso livro de GAJARDONI, Fernando da Fonseca. Flexibilizaçãa Procedimental... São Paulo: Atlas. 2008. Trabalho menos exaustivo, mas nem por isso menos importante, DIDIER JR., Fredie. Sobre dois importantes, e esquecidos, princípios do processo: adequação e adaptabilidade do procedimento. In: Revista Gênesis de Direito Processual Civil, Curitiba, n. 21, p. 530541, jul./set. 2001.

${ }_{238}$ Como reflexo disso, "as reformas do Código de Processo Civil tiveram como objetivo central a aceleração da tutela jurisdicional e, como postura metodológica predominante, a disposição de liberar-se de poderosos dogmas plantados na cultura processualística ocidental ao longo dos séculos". DINAMARCO, Cândido Rangel. Nova era do processo civil. São Paulo: Malheiros, 2003. P. 11.

239 MARINONI, Luiz Guilherme. Teoria Geral do Processo. São Paulo: RT, 6. ed. 2012. p. 229: "Demais, não é possível ignorar que não basta um único tipo de procedimento para todas as situações de direito material. O mito da uniformidade procedimental, ou da ideia da suficiência de um único procedimento 
procedimento conforme o direito material que se pretenda tutelar, ou, poderia ousar dizer, procedimentos distintos para cada tipo de situação de direito material posta ao crivo do Judiciário.

Embora tenha, reconhecidamente, natureza de direito público, o processo foi elaborado para veicular relações materiais privadas. A elaboração do conceito de processo, seja pelos teóricos da relação jurídica ou pelos defensores do procedimento em contraditório, sempre teve por objetivo principal formatar técnicas capazes de solucionar conflitos privados. Prova disso são os exemplos citados corriqueiramente pela doutrina processual. Mesmo quando são postos sob análise direitos indisponíveis, eles são decorrentes de relações essencialmente privadas, a exemplo dos processos que envolvem questões familiares. Ao explicar o conceito de processo Oskar von Bülow ${ }^{240}$ destacou que:

\begin{abstract}
El proceso es una relación jurídica que avanza gradualmente y que se desarrolla paso a paso. Mientras que las relaciones jurídicas privadas que constituyen la materia del debate judicial, se presentan como totalmente concluidas, la relación jurídica procesal se encuentra en embrión.
\end{abstract}

Existem grandes doutrinadores que se preocupam em tratar, pontualmente, de problemas inerentes à inclusão da Fazenda Pública no processo $^{241}$. No entanto, é preciso que o processo seja verdadeiramente pensado a partir dessa nova ótica ${ }^{242}$ - especialmente o processo se presta a controlar a execução de políticas públicas.

\title{
3.1. ADEQUAÇÃO E ADAPTABILIDADE DO PROCEDIMENTO
}

para todas as situações de direito substancial, deriva da tentativa de eliminar a influência do direito material sobre o direito processual [...]".

240 BÜLOW, Oskar von. La teoría de las excepciones procesales y los presupuestos procesales. Buenos Aires: EJEA, 1964.

241 No Brasil, a expressão do trabalho de Cássio Scarpinella Bueno impulsionou maiores pesquisas sobre o tema.

242 "Os esforços pela transformação do processo individualista, cunhado para acudir a conflitos de interesses individuais, num processo social, adequado à sociedade contemporânea, confluem num movimento em que, como aponta Barbosa Moreira (Tendências, p. 6-11), duas linhas-força podem ser identificadas: de um lado, o processo desperta para a necessidade de assegurar a tutela jurisdicional a conflitos de interesses que, por sua dimensão metaindividual, mal se acomodam no quadro dos esquemas processuais clássicos; de outro, busca imprimir ao próprio tratamento dos conflitos interindividuais feição mais consentânea com certas exigências básicas do Estado social de direito, facilitando o acesso à justiça, independentemente de desníveis culturais, sociais e econômicos, de modo a tornar operativo o princípio no plano substancial. As duas vertentes, como se viu, espelham a preocupação central do processualista contemporâneo em seus esforços rumo à universalidade da tutela jurisdicional" GRINOVER, Ada Pellegrini. Modernidade do direito processual brasileiro. In: O Processo em Evolução. 2. Ed. Rio de Janeiro: Forense, 1998. P. 13 
O discurso da efetividade processual deve vir acompanhado da compreensão acerca da variedade de direitos materiais existentes. Para os direitos privados, muito se tem dito e escrito sobre os mecanismos de potencialização do instrumento processual como forma de garantir aos litigantes tutto quello e proprio quello ${ }^{243}$ a que tenham direito. Pouco se consegue avançar, porém, no que diz respeito ao chamado direito material de interesse público. O que se tem atualmente sobre o tema gira em torno das ações coletivas, em virtude de seu natural impacto social.

Um tema que parece negligenciado quanto ao seu tratamento processual é o do controle de políticas públicas, que, embora deva ser realizado pela via das ações coletivas, acaba por sofrer interferência de ações individuais ${ }^{244}$. O verdadeiro controle de políticas públicas só pode ser feito por ações coletivas, cuja coisa julgada é erga omnes, atendendo à universalidade e à igualdade próprias dessas políticas ${ }^{245}$. As ações individuais só incidem indiretamente nas políticas, em termos negativos (pois subtraem recursos destinados às políticas públicas em geral) ou positivos (quando, por conta de sua repetição, conseguem modificá-las ou atualizá-las, a exemplo dos medicamentos para tratamento de aids e diabetes). O foco sobre o assunto foi colocado pelo grupo de estudos e pesquisas formado no âmbito do Centro Brasileiro de Estudos e Pesquisas Judiciárias (CEBEPEJ), à época presidido por Kazuo Watanabe.

Liderado por Ada Pellegrini Grinover, esse grupo pôs-se a discutir o tema do controle de políticas públicas e suas vertentes materiais e processuais - objetivos, limites e técnicas de realização. Todo material produzido deu origem a uma obra coletiva ${ }^{246}$ - coordenada por Kazuo Watanabe e Ada Pellegrini Grinover. Essa obra, além de servir de provocação ao

243 CHIOVENDA, Giuseppe. "Dell'azione nascente dal contrato preliminare" In: Saggi di diritto processuale civile. v. 1.Milano: Giuff rè, 1993. p. 110.

${ }_{244}$ "Mas os direitos fundamentais prestacionais não podem ser usufruídos exclusivamente no plano coletivo. A cada indivíduo também é assegurado o acesso ao Judiciário para fazer valer seu direito subjetivo à saúde. O princípio do acesso à Justiça, insculpido no inc. XXXV do art. $5^{\circ}$ da Constituição, assegura-o quer ao indivíduo, quer à coletividade. Nada impede, portanto, que o indivíduo peça ao Judiciário, em ações individuais, o fornecimento de um medicamento, uma internação hospitalar, uma cirurgia no exterior". GRINOVER. Ada Pellegrini. A coisa julgada no litisconsórcio facultativo unitário. O exemplo de ações coletivas e individuais no campo da saúde. Inédito.

$245 \quad$ "O instrumento adequado para o controle jurisdicional de políticas públicas em geral, e de saúde em particular, é constituído pelas ações coletivas, de objeto indivisível tanto quanto o é a política pública, em face de sua característica de universalidade". GRINOVER. Ada Pellegrini. A coisa julgada no litisconsórcio facultativo unitário.

${ }_{246}$ GRINOVER, Ada Pellegrini; WATANABE, Kazuo [coord]. O controle jurisdicional de políticas públicas. Rio de Janeiro: Forense, 2011, tendo sido publicada a segunda edição no ano de 2013. 
debate, fomentou discussões acadêmicas sobre a redação de um Anteprojeto de Lei voltado à construção de um procedimento adequado à resolução judicial desse tipo de litígio.

A necessidade de efetivação dos direitos fundamentais não pode prescindir de um pensamento legítimo acerca do procedimento adequado a esse propósito. Não é suficiente buscar dentro da estrutura processual elementos que possam conduzir à satisfação da crise de direito apresentada ao Judiciário. Antes, é preciso que o processo aceite concretizar os objetivos apresentados pelo direito material e, para isso, forneça as técnicas que lhe são inerentes, atingindo, a partir daí, seu próprio intento de resolução das controvérsias ${ }^{247}$.

O processo ensimesmado e monotemático não é capaz de atingir o seu próprio objetivo, que é o de garantir a realização do direito material. O processo civil de interesse público ${ }^{248}$ deve ser capaz de concretizar a cidadania mediante a resolução de conflitos que envolvam uma crise de direito material público ${ }^{249}$, a exemplo do controle das políticas públicas.

Até o presente momento, o instrumental que vem sendo utilizado é todo voltado para satisfação de direitos privados, com observância somente do prazo diferenciado para resposta e interposição de recurso pelo Estado - matéria desde sempre regulamentada pelo CPC (art. 188). Mesmo as prerrogativas processuais conquistadas pela Fazenda Pública com a edição da Lei 9494/97 são sumariamente afastadas ${ }^{250}$.

247 "o conceito de efetividade implica uma consideração de meios e fins, podendo ter-se por efetivo aquele processo que atinge as finalidades a que se destina, considerando o conjunto de objetivos implícitos no direito material e a totalidade da repercussão da atividade jurisdicional sobre dada situação de fato. A identificação dessas finalidades, portanto, como acima mencionado, não pode ser buscada endogenamente no processo, a partir de fins localizados em seus próprios institutos, mas sim nos resultados aos quais está vocacionado. As finalidades endógenas do processo, que correspondem àqueles argumentos chamados de produção, ganharão o seu sentido quando conjugadas com objetivos mais amplos, identificados na consideração ampla do sistema jurisdicional, como um mecanismo de produção de decisões sociais" SALLES, Carlos Alberto de. Processo Civil de Interesse Público In: SALLES, Carlos Alberto de [org.]. Processo Civil e Interesse Público...São Paulo: RT, 2003. p. 51-2.

248 "processo civil de interesse público é sinônimo de processo civil voltado à resolução de conflitos de interesses originários da aplicação do direito material público" BUENO, Cássio Scarpinella. Processo civil de interesse público: uma proposta de sistematização. In: SALLES, Carlos Alberto de [org.]. Obra citada. p. 24.

249 "O processo é instrumento de realização do direito material. Quando o processo é voltado à efetivação do direito material público, é ele mecanismo de concretização da própria razão de ser do Estado Social, Democrático e de Direito a que se refere a Constituição Federal. É, assim, instrumento de efetivação da própria cidadania [...] BUENO, Cássio Scarpinella. Poder Público em Juízo. 5. ed. São Paulo: Saraiva, 2009. p. 328. A cidadania efetivada judicialmente não é de modelo tradicional, que decorre de lutas e conquistas políticas e sociais apesar do Estado. Nesse caso, o conceito aplicável é o de cidadania regulada. Para melhor compreensão do tema cf. SANTOS, Wanderley Guilherme dos. Cidadania e Justiça. A Política Social na Ordem Brasileira. 3. a ed. Rio de Janeiro: Campus, 1994.

${ }_{250}$ A realização de busca de precedentes no site do STJ, mediante utilização das palavras-chaves "tutela e antecipada e fazenda e pública e medicamento" gerou, em 15 de outubro de 2013, um resultado de 
Em nome do direito veiculado nos processo analisados - direito à saúde - o STJ, com base em entendimento anterior do STF, realizou a adaptação do procedimento ${ }^{251}$, fazendo ceder, inclusive, a garantia constitucional do pagamento pelo regime dos precatórios ${ }^{252}$. Disso decorrem duas conclusões: (i) quando há vontade política - do Judiciário - o procedimento é adaptado sem grandes esforços argumentativos; (ii) embora ocorra nesses casos o afastamento de garantia constitucional, a maior alteração que o Judiciário é capaz de fazer é utilizar o procedimento tradicional, conferindo à Administração o mesmo tratamento dispensado aos cidadãos.

Com esse reduzido leque de opções porque apegado às técnicas expressamente dispostas no ordenamento, o Judiciário corre o risco de ver, em breve tempo, o crescente descrédito do instrumento utilizado para realização de seu mister ${ }^{253}$. Nessa nova dinâmica impressa por normas de direito material público, é preciso que as normas processuais sejam repensadas a fim de resguardar a integridade e utilidade do sistema ${ }^{254}$. Os atos administrativos (responsáveis pelo planejamento e execução das políticas públicas) possuem estrutura completamente diversa dos atos praticados sob o regime do direito

42 acórdãos sobre o tema. Na mesma data, a busca no site do STF com as mesmas palavras-chaves gerou apenas uma entrada. Embora o STF tenha inúmeras manifestações sobre o tema, seu sistema de busca é bastante inferior ao do STJ.

251 "O direito à saúde deve prevalecer sobre o princípio da impenhorabilidade dos recursos públicos. Nas palavras do Min. Teori Albino Zavascki, pode-se ter por legítima, ante a omissão do agente estatal responsável pelo fornecimento do medicamento, a determinação judicial do bloqueio de verbas públicas como meio de efetivação do direito prevalente. BRASIL. Superior Tribunal de Justiça. REsp 840.912/RS, Primeira Turma, julgado em 15.2.2007, DJ 23.4.2007)”. BRASIL. Superior Tribunal de Justiça. AgRg no REsp 935.083/RS, Rel. Ministro HUMBERTO MARTINS, SEGUNDA TURMA, julgado em 02/08/2007, DJ 15/08/2007, p. 268).

252 "Não há que se sujeitar os valores deferidos em antecipação de tutela ao regime de precatórios, pois seria o mesmo que negar a possibilidade de tutela antecipada contra a Fazenda Pública, quando o Supremo Tribunal Federal apenas resguarda as exceções do art. $1^{\circ}$ da Lei 9.494/97. Precedente". BRASIL. Superior Tribunal de Justiça. AgRg no REsp 935.083/RS, Rel. Ministro HUMBERTO MARTINS, SEGUNDA TURMA, julgado em 02/08/2007, DJ 15/08/2007, p. 268).

253 "[...] na exata proporção em que se tem, crescentemente, um maior número de lides ou de conflitos de interesses regidos primordialmente pelo direito material público, um processo civil voltado, tradicionalmente, à solução dos conflitos regidos pelo direito material privado, pode levar, em um curto espaço de tempo, à ineficiência ou à ineficácia daquele instrumental de resolução de conflitos de interesses. Justamente porque a qualidade dos conflitos que são colocados para serem resolvidos pelas mesmas regras instrumentais tem se alterado profundamente". BUENO. 2003. p. 24.

254 "na exata medida em que o direito material modifica-se substancialmente [...] as regras de sua aplicação conflituosa - as normas processuais civis - precisam ser revistas, relidas e reinterpretadas para que possam, mesmo diante desta substancial alteração, ter alguma valia e eficácia, para que possam realizar bem estes direitos materiais. Por definição, as normas processuais não podem ficar aquém das normas materiais sob pena de ineficiência de todo o sistema jurídico. Daí ser necessário e oportuno que seja feito um corte ou, quando menos, uma precisão no estudo do processo civil focando-se a outros direitos materiais [...] É o que se dá, não com exclusividade, mas em alto grau, como direito material público”. BUENO. 2003. p. 25. 
privado, razão pela qual não se pode aceitar que a estrutura de efetivação e sindicabilidade de ambos seja idêntica ${ }^{255}$.

\subsubsection{Princípios da adaptação e adequação}

As alterações procedimentais desejadas podem vir por mudanças legislativas (lege ferenda) ou judiciais realizadas por interpretação das disposições existentes (lege lata). Tomada a imperiosidade da correlação entre as técnicas estatais de solução de conflitos e os direitos materiais reconhecidos pelo ordenamento aos indivíduos, forçoso admitir que sempre haverá para o legislador uma diretriz que o oriente à constante atualização dos procedimentos e das técnicas processuais. Essa diretriz é conhecida como princípio da adequação. Por sua vez, o princípio da adaptabilidade atua endoprocessualmente, autorizando o magistrado a promover o aperfeiçoamento do procedimento quando o modelo apresentado não for útil ao seu objeto ou às partes do processo ${ }^{256}$.

É claro que os procedimentos não podem ser livremente alterados pelo Juízo. O ordenamento jurídico brasileiro fez uma clara opção por um sistema de legalidade das formas procedimentais, destacando constitucionalmente a competência exclusiva da União para legislar sobre matéria processual (art. 22, I) e a competência concorrente entre União, Estados e Distrito Federal para legislar sobre procedimentos em matéria procedimental (art. 24, XI). O processo tem natureza de matéria de ordem pública, razão pela qual não pode ser objeto de livre disposição pelas partes ou pelo Magistrado.

\footnotetext{
255 BUENO. 2003. p. 27-8.

256 Essa distinção entre os princípios da adequação e adaptabilidade é feita por Fernando da Fonseca Gajardoni e Fredie Didier Jr. "Fala-se em princípio da adequação para designar a imposição sistemática dirigida ao legislador federal e estadual para que construa modelos procedimentais aptos para a tutela especial de certas partes ou do direito material; e princípio da adaptabilidade (ou da elasticidade processual) para designar a atividade do juiz de flexibilizar o procedimento inadequado ou de reduzida utilidade para melhor atendimento das peculiaridades da causa. [...] ambos os princípios se operam do ponto de vista subjetivo (partes) ou objetivo (direito material).” GAJARDONI. Obra citada. pp. 134-5.

"Este princípio pode ser visualizado, de acordo com a doutrina, em dois momentos: a) o préjurídico, legislativo, como informador da produção legislativa do procedimento em abstrato; b) o processual, permitindo ao juiz, no caso concreto, adaptar o procedimento de modo a melhor afeiçoá-lo às peculiaridades da causa. Quiçá, para fins didáticos, devêssemos nomeá-lo apenas no primeiro momento de princípio da adequação, enquanto, no segundo, de princípio da adaptabilidade; um, abstrato e prévio, outro, concreto e reparador. É a terminologia que adotamos”. DIDIER JR. Obra citada. p. 6.
} 
No entanto, como lembra Fernando Gajardoni, não existem sistemas puros, mas apenas tendentes à rigidez ${ }^{257}$. A opção pela rigidez, explica o autor, decorre da manutenção de segurança e previsibilidade do sistema, tornando-o confiável. No entanto, após ponderar esses valores com outros inerentes à própria tutela jurisdicional (celeridade, efetividade ${ }^{258}$ e contraditório) Fernando Gajardoni aposta na viabilidade de flexibilização procedimental mesmo em sistemas rígidos como o brasileiro ${ }^{259}$.

Primeiramente, destaca a já conhecida morosidade legislativa em promover a adequação dos procedimentos judiciais aos mais diversos direitos materiais reconhecidos pelo ordenamento jurídico - especialmente em relação às regras processuais, que estão colocadas sob o monopólio do legislativo federal. Então, seria impossível esperar, sempre, por alterações legislativas para concessão de uma tutela jurídica adequada. Em razão disso, a depender da pessoa ${ }^{260}$ ou do bem jurídico presente em uma demanda ${ }^{261}$, o Magistrado poderia, observando garantias constitucionais do processo, promover a adaptação do procedimento.

$257 \quad$ GAJARDONI. Obra citada. p. 79.

258 "quando se fala em tutela jurisdicional, vem à mente, de imediato, o princípio da inafastabilidade (direito constitucional de ação), segundo o qual nenhuma lesão ou ameaça de lesão será afastada da apreciação do Poder Judiciário (art. $5^{\circ}, \mathrm{XXXV}, \mathrm{CF} / 88$ ). O conteúdo desta garantia, durante muito tempo, fora visto apenas como a estipulação do direito de ação e do juiz natural. Sucede que a mera afirmação destes direitos em nada garante a sua efetiva concretização; surge, assim, a noção de tutela jurisdicional qualificada. Não basta a simples garantia formal do dever do Estado de prestar a Justiça; é necessário adjetivar esta prestação estatal, que há de ser rápida, efetiva e adequada". DIDIER JR. Obra citada. p. 7.

259 É a ideia transmitida por Samuel Meira Brasil Jr. ao abordar o tema do devido processo legal substancial. De acordo com o autor, “o alcance do princípio do devido processo legal vai além do mero sentido literal da expressão. Ele não se limita a impor obediência a um procedimento meramente legal, mesmo que regulado pela técnica processual, como uma leitura inadvertida poderia aparentar. O princípio merece ser considerado, dada a sua inegável importância, sob o prisma de seu aspecto substancial". BRASIL JR. Obra citada. p. 126. E prossegue, “fixada a premissa de que o adjetivo 'devido' deve ser compreendido como 'adequado, necessário ou proporcional', vejamos os demais elementos linguísticos do princípio [...] a expressão 'legal' não pode ser limitada à noção de lei. [...] O 'legal' da expressão tem o sentido de 'jurídico', de 'direito'. Portanto, o 'devido processo legal' deve ser compreendido como 'adequada, necessária e proporcional atuação do direito” BRASIL JR. Obra citada. p. 127.

"A adequação subjetiva do processo se opera em razão dos litigantes. São exemplos: a) intervenção obrigatória do Ministério Público nas ações de incapazes (art. 82, I, CPC); b) diferenciação de regras de competência (alimentando, art. 100, II, CPC; entes públicos federais, art. 109, I, CF/88); c) incapacidade processual para litigar em certos procedimentos (art. $8^{\circ}$, LF 9.099/95); d) prazos especiais (art. 188, CPC) etc". DIDIER JR. Obra citada. p. 9.

261 Três são, basicamente, os critérios objetivos de que se vale o legislador para adequar a tutela jurisdicional pelo procedimento: um, a natureza do direito material, cuja importância e relevância impõem uma modalidade de tutela mais efetiva; o segundo, a forma como se apresenta o direito material no processo; o terceiro, a situação processual da urgência. São exemplos do primeiro critério as possessórias, os alimentos, a busca e apreensão em alienação fiduciária, a liminar em ação civil pública etc. Do segundo critério, exsurgem o mandado de segurança, ação monitória e a tutela antecipada genérica do art. 273, CPC, recentemente implementada no direito brasileiro. São exemplos de tutela de urgência os procedimentos especiais de alimentos, mandado de segurança preventivo etc. 
Os critérios apresentados por Fernando Gajardoni são: finalidade, contraditório útil e motivação. A finalidade, como já dito, pode ser a proteção a uma pessoa ou a determinado bem jurídico; o contraditório útil permite assegurar a previsibilidade e segurança do sistema mesmo com a flexibilização, já que às partes seria dada a oportunidade de participar-influindo $o^{262}$ na decisão judicial que adapta o procedimento ao caso concreto; e, a motivação, decorrente de garantia inserta no art. 93, IX da Constituição, serviria como forma de controle de possível arbitrariedade cometida pelo Magistrado (o que inclui o desrespeito ao contraditório).

Como regra, portanto, vige um sistema procedimental rigidamente controlado por normas oriundas do processo legislativo tradicional ${ }^{263}$. As situações que se puserem a descoberto, sem previsão legislativa sobre adequação do procedimento aos elementos subjetivo ou objetivo da demanda, podem ser contempladas com a atuação jurisdicional, desde que respeitadas as demais garantias constitucionais do processo ${ }^{264}$.

Esse entendimento torna aplicável lição anteriormente apresentada por Cândido Rangel Dinamarco, para quem os princípios e garantias constitucionais somente cumprem sua verdadeira função se colaborarem para a obtenção de resultados justos. Se na prática uma dessas normas se apresentar como impeditivo de obtenção de uma tutela jurisdicional adequada $^{265}$ e efetiva, ela pode ser afastada mediante uma interpretação sistemática capaz

$262 \quad$ GAJARDONI. Obra citada. p. 89

263 "O princípio da adaptabilidade, naturalmente, tem natureza subsidiária. Só incide nos casos em que o legislador não criou especificamente um procedimento individualizado e adequado para a tutela do direito ou da parte (como se pressupõe ter ocorrido com os procedimentos especiais). Se o procedimento é ideal e atende com perfeição às características do caso, não há espaço para adaptação" GAJARDONI. Obra citada. p. 137.

Embora defenda a adesão do ordenamento jurídico brasileiro ao sistema de flexibilização por força de lei, em que somente disposição legal pode autorizar o juiz a proceder à adaptação do procedimento em questão, Fernando Gajardoni entende que "nas demais hipóteses em que, apesar da omissão legislativa, as variantes rituais forem indispensáveis para a construção de um procedimento aderente à qualidade especial das partes ou ao direito material, não me parece afastada a possibilidade de ser permitida a adaptação com base na instrumentalidade das formas. Não sendo, todavia, o regime padrão brasileiro, o seu emprego só se dará em caráter absolutamente excepcional (inexistência de procedimento legal útil ou adequado) e observados os condicionamentos já estudados outrora (finalidade, contraditório útil e motivação)". GAJARDONI. Obra citada. p.. 137.

265 Para Ada Pellegrini Grinover, “compreende-se modernamente, na cláusula do devido processo legal, o direito ao procedimento adequado: não só deve o procedimento ser conduzido de acordo com as garantias do devido processo legal, como também há de ser aderente à realidade social e consentâneo com a relação de direito material controvertida". GRINOVER, Ada Pellegrini. Princípios e garantias constitucionais. In: O Processo - III Série. Brasília: Gazeta Jurídica. 2013. p. 6. 
de prestigiar princípios ou garantias mais adequados a esse fim $^{266}$. Como bem explica Samuel Meira Brasil Jr. ${ }^{267}$ :

\begin{abstract}
Quando dois princípios conduzem à concreção de dois juízos inconciliáveis, um princípio deve ser aplicado em detrimento do outro. Mas esta preponderância de um princípio sobre o outro não significa que o princípio excluído é inválido, nem que foi criada uma exceção a uma norma jurídica.
\end{abstract}

Ao juiz, portanto, compete velar pela adequação do procedimento ao direito material apresentado à apreciação do Poder Judiciário, de forma a alcançar a efetividade máxima da tutela jurisdicional. Quando não houver autorização normativa expressa para flexibilização do procedimento, caberá ao magistrado sua adaptação.

\title{
3.1.1.1. Proposta do novo CPC
}

O novo Código de Processo Civil cuidou de abordar tema que vinha sendo abandonado pela legislação pátria, qual seja, a coletivização de ações individuais. A técnica, embora sirva para relações jurídicas materiais de caráter exclusivamente privado, é importante porque remete ao impacto social de certos conflitos, que envolvem um número indeterminado ou indeterminável de pessoas. Essa técnica é especialmente cara ao processo de controle de políticas públicas, que, como visto, embora seja bem realizado por ações coletivas, acaba sofrendo os efeitos da multiplicidade de ações individuais.

Com previsão no art. 334, é preciso que a matéria discutida tenha relevância social e dificuldade de formação de litisconsórcio. A iniciativa da coletivização pode ser tomada pelo Ministério Público, pela Defensoria Pública ou pelo autor da ação, que pode requerer a conversão de sua individual em uma coletiva. A conversão pode se dar em duas situações: quando o pedido (i) tenha alcance coletivo, em razão da tutela de bem jurídico difuso ou coletivo, assim entendidos aqueles definidos pelo art. 81, parágrafo único, incisos I e II, da Lei $\mathrm{n}^{\text {o }}$ 8.078, de 11 de setembro de 1990, e cuja ofensa afete, a um só

\footnotetext{
266 "A adoção de dessa premissa metodológica manda, em primeiro lugar, que todos os princípios e garantias constitucionais sejam havidos como penhores da obtenção de resultados justos, sem receber um culto fetichista que desfigura o sistema. Manda, também, que eles seja interpretados sistematicamente e em consonância com os valores vigentes ao tempo da interpretação. Muitas vezes é preciso sacrificar a pureza de um princípio, como meio de oferecer tutela jurisdicional efetiva e suficientemente pronta, ou tempestiva; muitas vezes, também, é preciso ler uma garantia constitucional à luz de outra, ou outras, sob pena de conduzir o processo e os direitos por rumo indesejáveis" DINAMARCO. 2003. pp. 13-4.

$267 \quad$ BRASIL JR. Obra citada. pp. 91-2.
} 
tempo, as esferas jurídicas do indivíduo e da coletividade; ou (ii) tenha por objetivo a solução de conflito de interesse relativo a uma mesma relação jurídica plurilateral, cuja solução, pela sua natureza ou por disposição de lei, deva ser necessariamente uniforme, assegurando-se tratamento isonômico para todos os membros do grupo.

Ambas as situações são encontradas no controle de políticas públicas, especialmente nas de saúde. Isso porque, como bem destacado por Ada Pellegrini Grinover, é possível identificar nesses casos ações individuais, ações individuais com efeitos coletivos e ações pseudoindividuais $^{268}$ - as duas últimas contempladas, respectivamente, pelos incisos I e II do art. 334 do novo CPC.

A técnica, por ser nova, ainda demandará inúmeras dúvidas em relação à sua utilização. Durante o Congresso de jovens processualistas organizado pelo IBDP, foram elaborados alguns enunciados como forma de auxiliar à interpretação e aplicação ${ }^{269}$. Dentre os enunciados, o que mais chama atenção é o que restringe a oposição das partes à conversão das ações em coletivas à ausência dos pressupostos legais. Ou seja, a parte não pode obstar, por mera liberalidade, a conversão da ação individual em coletiva, sendo possível apresentar objeção somente em relação ao não preenchimento dos pressupostos indicados no caput do art. 334.

A inclusão do art. 334 no novo CPC faz parte de um ainda tímido movimento do legislador em fornecer ao Poder Judiciário técnicas necessárias à condução dos processos de interesse público, relegando aos magistrados a tarefa de construir, na prática, toda estrutura necessária à correta prestação jurisdicional aos casos submetidos à apreciação.

\subsubsection{Processo de interesse público: modificação da estrutura tradicional}

\footnotetext{
268 GRINOVER, Ada Pellegrini. A coisa julgada no litisconsórcio facultativo unitário...

269 36. Art. 334, I. É presumida a relevância social na hipótese do inciso I do art. 334, sendo dispensável a verificação da "dificuldade de formação do litisconsórcio". (Grupo: Conversão de Ação Individual em Coletiva)

37. Art. 334, II. É necessária a efetiva demonstração da relevância social e da dificuldade de formação do litisconsórcio. (Grupo: Conversão de Ação Individual em Coletiva)

38. Art. 334. É dever do juiz intimar os legitimados do art. 334 do CPC para, se for o caso, requerer a conversão, aplicando-se, por analogia, o art. 139, X, do CPC. (Grupo: Conversão de Ação Individual em Coletiva)

39. Art. 334. Havendo requerimento de conversão, o juiz, antes de decidir, ouvirá o autor e, caso já tenha sido citado, o réu. (Grupo: Conversão de Ação Individual em Coletiva)

40. Art. 334. A oposição das partes à conversão da ação individual em coletiva limita-se à alegação do não preenchimento dos seus pressupostos. (Grupo: Conversão de Ação Individual em Coletiva)
} 
O desenvolvimento do constitucionalismo durante todo o século XX foi responsável por grandes mudanças no cenário jurídico dos países de tradição ocidental, que ainda seguiam um modelo liberal de raízes francesas ou americanas, por inspiração dos primeiros documentos tidos, na forma como hoje conhecidos, por Constituição.

A influência do liberalismo sobre os ordenamentos jurídicos foi responsável pela contenção da influência do Estado no cotidiano da sociedade, mediante a utilização do princípio da legalidade ${ }^{270}$. Com esse mesmo instrumental, foi possível confinar o Poder Judiciário em um espaço menos prestigioso no arranjo dos Poderes estatais, colocando-o como mero aplicador das leis existentes aos casos postos à sua apreciação.

Com o esgotamento desse modelo e, principalmente, com a derrocada das sociedades europeias no pós-guerras, foi-se construindo uma alternativa completamente diversa, que pudesse permitir ao Estado uma atuação mais frequente e visível, com deveres prestacionais para com sua população, de forma a poder suavizar as marcadas diferenças existentes nos estratos sociais. Se antes, portanto, havia um isolamento formal imposto ao Estado, agora, ele passa a ser chamado a atuar na sociedade. Essa é a transição do chamado Estado Liberal para o Estado Social ou do Bem-Estar Social.

O que antes era visto como assistencialismo, agora passa a ser item obrigatório da pauta de prioridades dos governantes. Ou, pelo menos, assim deveria ser. Nos países já desenvolvidos, com seus processos democráticos mais consolidados, essa virada foi suficiente para que a população pudesse ser beneficiada por uma nova postura advinda do Estado, mediante atuação do Legislativo e do Executivo.

Nos países periféricos, onde o processo democrático ainda estava longe de se consolidar, as promessas constitucionais permaneciam descumpridas e não puderam ser cobradas, uma vez que os direitos hoje chamados de sociais encerrariam somente projetos de execução

\footnotetext{
$270 \quad$ "los aspectos del Estado liberal de derecho indicados remiten todos a la primacía de la ley frente a la Administración, la jurisdicción y los ciudadanos. El Estado liberal de derecho era un Estado legislativo que se afirmaba a sí mismo a través del principio de la legalidad”. ZAGRABELSKY, Gustavo. El derecho dúctil: ley, derechos e justicia. Madrid: Editorial Trotta. 1995. p. 24.
} 
em longo prazo, ou melhor dito, não passavam de normas programáticas, desprovidas de

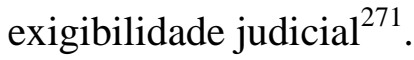

Esse foi o ponto primordial de modificação do modelo vigente: a insatisfação com sua incapacidade de se fazer cumprido, de ter suas promessas satisfeitas. Com isso, a solução buscada concentrou-se em um sistema mais eficaz, que contivesse em si as ferramentas necessárias à garantia de suas próprias promessas, que embora possam ter sido atenuadas ou postergadas nesse período de transição, permaneceram com o mesmo perfil adotado pelo Estado Social, sem descurar da proteção contra possíveis arbitrariedades institucionais $^{272}$.

O Estado Democrático de Direito, então, surge com uma nova proposta constitucional, que se pretende normativamente mais forte, porém, ao mesmo tempo, capaz de receber os influxos advindos da modificação dos padrões sociais, sendo mais dinâmica e aberta. Nesse contexto, os países latino-americanos, que não haviam experimentado as alterações promovidas pelo Estado Social, passam agora a incluir em suas constituições as chamadas garantias fundamentais ${ }^{273}$.

O processo de autodeterminação constitucional ${ }^{274}$, responsável pela transferência da normatização de princípios e regras para a sede constitucional e pelo consequente enfraquecimento do principio da legalidade, insere nos textos constitucionais técnicas próprias para a tutela dos direitos fundamentais ${ }^{275}$, que passam, portanto, a ser judicialmente exigíveis.

\footnotetext{
271 FREIRE JR., Américo Bedê. Controle Judicial de Políticas Públicas. São Paulo: RT. P. 25.

272 "el Estado de Derecho busca siempre limitar y restringir el poder y el dominio del Estado en favor de la libertad del individuo y realizar el derecho material" BÖCKENFÖRDE, Ernst Wolfgang. Estudios sobre el Estado de Derecho y la democracia. Madrid: Editorial Trotta, 2000. P. 44.

273 "A partir de las dos últimas décadas del siglo XX la mayoría de los países latinoamericanos, aunque tardíamente, ingresa en lo que se ha considerado la 'fase madura' de uno de los fenómenos más importantes que ha sellado la evolución de la justicia en general, la 'constitucionalización de las garantías' o, si se prefiere, la 'procesalización del derecho constitucional". BERIZONCE, Roberto Omar. Los conflitos de interés público. In: Revista Peruana de Derecho Processal. N. 17. Ano XVIII. Lima: Editorial Comunitas, 2013. p. 126.

274 BINENBOJN. Obra citada. p. 36-7.

275 "Ahora bien, el principal instrumento de tutela de los derechos fundamentales está dado por las instituciones, procedimientos y técnicas procesales y organizacionales, y en particular por las acciones y remedios constitucionales, que genéricamente componen los denominados procesos constitucionales". BERIZONCE. 2013. p. 127.
} 
Com isso, há um progressivo deslocamento das manifestações democráticas para o âmbito do Judiciário, com intervenção cada vez maior dos juízes e das Cortes nas políticas públicas instituídas pelos Poderes Executivo e Legislativo e a utilização do Judiciário pelos atores políticos na busca por uma solução de conflitos sociais e a crescente utilização política de um discurso afeto ao direito ${ }^{276}$.

O advento das ações coletivas, tais como as ações civis públicas e ações populares, começa a dar vazão àquelas demandas sociais que ficam retidas pelos instrumentos clássicos de representação. Nesse ponto, a questão relativa ao controle jurisdicional das políticas públicas fica mais evidente ${ }^{277}$. O processo que veicula pretensões de direito material público não se opõe, propriamente, ao caráter privado das demais relações, mas sim à individualidade como nota principal do litígio apresentado ${ }^{278}$.

Se as normas processuais devem ser capazes de atender às demandas apresentadas pela sociedade, traduzidas pela linguagem do direito em direitos fundamentais, o processo precisa assumir uma vertente funcional, "destacando dessa maneira sua relação com o ordenamento jurídico e com os sistemas político, econômico e social" ${ }^{279}$. No entanto, as técnicas para tutela desses direitos são postas em xeque quando não se mostram aptas à acolhê-los, em suas particularidades e complexidades ${ }^{280}$.

276 SMUlOVITZ, Catalina; URRIBARRI, Daniela. Poderes Judiciales en America Latina...In: Cohesión social en América Latina: bases para una nueva agenda democrática. Disponível em: www.plataformademocratica.org. Neste mesmo sentido, Bernardo Sorj disse em palestra proferida na III Câmara Técnica dos Balcões de Direito: A grande linguagem contemporânea para reivindicação passou a ser a linguagem dos direitos. [...] Ou seja, hoje aquele que fala em Direito não está pensando no Direito, está usando uma linguagem política. A linguagem política contemporânea deixou de ser a política, passou a ser a linguagem dos direitos. Transcrição disponível em: www.bernardosorj.com. Acesso em: 28 de fevereiro de 2009.

277 "Los conflictos de interés público o estratégicos son aquellos que involucran derechos fundamentales colectivos, canalizados a través de los denominados litigios de derecho público". BERIZONCE. 2013 p. 131.

278 SALLES. Obra citada. p. 40

279 SALLES. Obra citada. p p. 41-2.

280 "Transformar o ideário constitucional em condutas e realidades concretas não é, certamente, tarefa da alçada exclusiva do Poder Judiciário. Ao contrário, trata-se de empreendimento necessariamente compartilhado entre os Poderes do Estado e a própria sociedade. Urge, porém, que esta grande causa seja de uma vez encetada, com coragem e vontade política, e o papel do Judiciário será, induvidosamente, de maior importância. É certo que a efetivação dos programas constitucionais dependerá fundamentalmente da iniciativa dos demais Poderes, aos quais compete a formulação de políticas públicas adequadas e a aprovação dos mecanismos institucionais e legais para a respectiva implementação. Mas o Judiciário não poderá se eximir da sua fatia de responsabilidade, que consiste, essencialmente, em prestar jurisdição mediante pronunciamentos que extraiam do sistema normativo soluções as mais adequadas possíveis à produção dos resultados previstos pelo constituinte". ZAVASCKI, Teori Albino. Eficácia social da prestação jurisdicional. Disponível em: https:/ /www.google.com.br/url?sa=t\&rct=j\&q=\&esrc=s\&source=web\&cd=1\&ved=0CC0QFjAA\&url=http $\% 3 \mathrm{~A} \% 2$ 
Por essa razão, o aporte dos conflitos decorrentes da inexistência ou inadequação das políticas sociais no Poder Judiciário reforça a natureza instrumental do processo ${ }^{281}$, como mecanismo destinado a atender as necessidades apresentadas pelo direito substancial ${ }^{282}$, tornando-se potencialmente efetivo. A satisfação das demandas é que garante ao processo a qualidade de efetivo e não sua força cogente decorrente das sanções previstas pelo ordenamento $^{283}$.

Essa característica é acentuada no processo civil de interesse público, onde a atuação judicial deve ser guiada pela restauração do diálogo entre representantes e representados, reforçada a busca por soluções consensuais em detrimento do cumprimento impositivo de decisões completamente formuladas pelo magistrado. O juiz passa a ser somente mais um ator no processo de construção da solução a ser aplicada a cada caso que lhe seja apresentado; junto a ele, a autoridade responsável pela política pública questionada e o autor da ação, representado por uma só pessoa (como é o caso do Promotor) ou por várias (os representantes de uma associação) ${ }^{284}$.

Como a resolução desses problemas é multidisciplinar e envolve a complexidade de toda estrutura de uma política pública, o magistrado deve ser capaz de preparar o provimento jurisdicional final de forma a permitir uma execução menos restritiva, na qual o Judiciário F\%2Fwww2.senado.leg.br\%2Fbdsf\%2Fhandle\%2Fid\%2F176210\&ei=gsvUUsfuG5C4kQeOiYDYCg\&usg= AFQjCNE2BNbG8qwfMYL_Lq5uhfjqa6yXLg\&sig2=MeZ-2mCyPte0yl6JyChPJAP. 293-4

281 "En paralelo, la explosión de la conflictividad colectiva en sectores tan diversos como los que se relacionan con la defensa del medio ambiente, el patrimonio común histórico o artístico y paisajístico, la salud pública y las relaciones de consumo en general, entre otros, requiere de un instrumental procesal adecuado, novedoso y apto para tutelar los específicos derechos e intereses "difusos" y "colectivos" o "fragmentarios" y superar las congénitas dificultades procedimentales que plantean tales acciones, lo que ha implicado un denodado esfuerzo creativo de la propia magistratura". BERIZONCE, Roberto Omar. Activismo Judicial y Participación en la Construcción de las Políticas Públicas. Disponível em: http://www.civilprocedurereview.com/busca/baixa_arquivo.php?id=24\&embedded=true.

${ }_{282}$ BEDAQUE, José Roberto. Direito e Processo... 4. Ed. São Paulo: Malheiros, 2006b. p. 17.

283 "De fato, a interpretação da efetividade do processo não pode ser feita exclusivamente através de sua capacidade de decidir imperativamente, impondo suas decisões e confirmando o ordenamento positivo. Esse enfoque leva a afastar do direito processual importantes atributos que não estão ligados ao direito material e sua realização, mas são inerentes à própria prestação jurisdicional, realizando-se em seu iter procedimental e nas implicações secundárias para o sistema jurídico e social" SALLES. Obra citada. p. 49.

"La actuación judicial en la etapa de ejecución de sentencia no habrá de consistir en la imposición compulsiva de una condena, entendida como una orden detallada y autosuficiente, sino en el seguimiento de una instrucción fijada en términos más o menos generales, cuyo contenido concreto habrá de ser construido a partir del diálogo que necesariamente se producirá entre las partes, incluyendo a la autoridad pública, y el tribunal. En consecuencia, en la etapa de ejecución corresponderá a la autoridad pública demandada (y vencida) determinar el modo más adecuado de cumplir con la sentencia de condena y, por su parte, el tribunal actuante controlará la adecuación de las medidas concretas a la orden que ha impartido" BERIZONCE. 2013. p. 137. 
participe como fiscal e garantidor, dentro de uma microinstitucionalidade ${ }^{285}$ estruturada de para receber adequadamente o litígio proposto.

Como ressaltado, o Judiciário, embora não seja o responsável direto e exclusivo pelas soluções apresentadas para satisfação do direito tutelado, não deixa de ser indispensável para o desfecho do processo. Isso porque, o processo de interesse público, apesar de dialogado, pode sofrer reveses decorrentes da reiterada inércia ou incompetência da autoridade responsável pela política pública em questão. Nesses casos, a aptidão do Poder Judiciário para impor suas decisões, serve como estímulo e garantia para que o processo possa ter o fim adequado à resolução do litígio.

Embora a equivocada ideia de coadjuvação do magistrado no processo de interesse público possa transmitir a impressão de que seu papel tenha sido diminuído, é muito óbvio o aumento de suas atribuições no contexto geral dos Poderes instituídos. À medida que o direito passa a ocupar o espaço da política, como dito, os juízes se tornam, nos dizeres de Antoine Garapon, os "guardiões de promessas", que se incumbem de portar os ideais de justiça constitucionalmente delineados ${ }^{286}$.

Essas promessas, como dito, estão atreladas à parcela não cumprida do Estado Social e compõem o chamado núcleo duro, onde se encontram os direitos à saúde e à educação ${ }^{287}$. Fica claro, sob esse prisma, que os litígios de interesse público afetam grupos ou categorias cujas demandas implicam na correção de grandes instituições ou serviços públicos ${ }^{288}$, daí porque dizer que esse tipo de processo se afasta do modelo tradicional de caráter individual e demanda a formatação de técnicas diferenciadas.

\footnotetext{
$285 \quad$ BERIZONCE. 2013. p. 138.

286 "en Brasil generalmente las decisiones se apoyan de modo exclusivo en la Constitución". BERIZONCE. 2013. p. 129.

287 "El punto a lo primero, se destaca la tutela preferente que habitualmente se concede a los derechos que integran el 'núcleo duro': derecho a la vida, a la salud, al medio ambiente sano, personalísimos, a la dignidad, a la educación, a la vivienda y a las condiciones dignas de vida y, en general, a los denominados derechos económicos, sociales y culturales (DESC)”. BERIZONCE. 2013. p. 127-8.

288 "Tales litigios involucran a grupos o clases de integrantes dispersos y a menudo indeterminados o indeterminables, cuyos reclamos implican poner en debate el funcionamiento de grandes instituciones o servicios públicos - sistemas escolares, establecimientos carcelarios, instituciones de salud mental, de seguridad o asistencia públicos, etc. -, que requerían remedios que debían arbitrarse generalmente a largo plazo”. BERIZONCE. 2013. p. 131-2.
} 
Daí porque se afirma, com segurança, que se o legislador não cuida de atualizar o instrumental e proporcionar as técnicas mais adequadas à solução de controvérsias dessa natureza, compete ao juiz adaptar o procedimento de forma a proporcionar a melhor prestação jurisdicional $^{289}$.

O juiz é, portanto, necessariamente mais ativo e deve assumir a responsabilidade pela escolha do instrumental correto e pelo bom desenvolvimento do processo. Daí surge a figura do ativismo judicial. O termo se perdeu entre considerações positivas e negativas acerca do fenômeno, especialmente no período em que o controle judicial de políticas públicas ainda era recebido com desconfiança e resistência.

A opção de Roberto Berizonce foi pelo termo juiz ativista e não somente ativo. Para ele, o juiz ativo seria, em resumo, aquele que se desincumbe de suas funções de maneira diligente, ao passo que o ativista é aquele portador de uma visão progressista que acompanhe a realidade social e saiba transformar suas decisões em instrumentos de consagração dos valores vigentes ${ }^{290}$.

A falta de experiência na condução desse tipo de litígio e a ausência de parâmetros legais para predefinição das técnicas disponíveis conferem ao processo de interesse público o caráter experimental, com utilização de conhecimentos advindos, por exemplo, dos meios alternativos de solução de controvérsias, em que as partes de um conflito podem chegar alcançar sua solução mediante arbitramento impositivo de um terceiro, pela aceitação de

289 "a busca de decisões judiciais que levem à eficácia social do direito dever ser empreendida exaurindo-se os mecanismos oferecidos pelo próprio sistema jurídico do Estado de direito constitucional”. ZAVASCKI. Obra citada. p. 293-4

290 "A la figura clásica de un juez "pasivo", se opone otra de juez "activo" y una todavía diversa de juez "activista". La cuestión reside en diferenciar éstas dos últimas y especialmente caracterizar al "activista".

"Activista", denota no una cualidad puramente mecaniscista o física, cual sería la aceleración o la diligencia, sino un sentido mucho más profundo que deriva del actuar activo pero, además, enderezado a la obtención de una finalidad en la que predominan los valores fundamentales. El juez que pronuncia sus decisiones y cumple sus deberes funcionales diligentemente dentro de los plazos legales, podrá ser considerado activo; será "activista" si, además, a partir de una visión progresista, evolutiva, reformadora, sabe interpretar la realidad de su época y le confiere a sus decisiones un sentido constructivo y modernizador, orientándolas a la consagración de los valores esenciales en vigor. El "activismo" se verifica principalmente, aunque no con exclusividad, a través de la sentencia en cuanto a las reglas jurídicas materiales; pero también en la conducción del procedimiento. En uno y otro campo reconoce, naturalmente, precisas limitaciones". BERIZONCE, Roberto Omar. Activismo Judicial y Participación en la Construcción de las Políticas Públicas. Disponível em: http:/ /www.civilprocedurereview.com/busca/baixa_arquivo.php?id=24\&embedded=true. 
propostas formuladas por terceiro ou mesmo por acordo realizado entre as próprias partes, do qual o terceiro participa somente para garantir o equilíbrio das discussões.

Esse método permite que haja, simultaneamente, a satisfação dos direitos tutelados e o respeito às condições estruturais de cada ente federado, que muitas vezes encontra dificuldades orçamentárias para fazer frente a uma deficiência histórica em determinada política pública ${ }^{291}$.

Do exposto, quais podem ser os elementos próprios de um processo de interesse público? Para Roberto Berizonce, seriam: (a) o ativismo procedimental e ampliação dos poderes do juiz, especialmente quanto à concessão de tutelas de urgência, em razão da delicadeza dos direitos submetidos a esse tipo de demanda; (b) a solução dialogada por impulso do juízo com maior publicidade e transparência, que possa servir como fator de pressão ao compromisso das partes na busca por uma solução consensual; (c) a decisão judicial, ainda que reconheça a omissão ou deficiência na prestação da política pública, tem caráter prospectivo e produz efeitos diretos somente em relação às políticas públicas do setor ou serviço questionado; (d) o diálogo promovido no curso do processo serve como elemento facilitador do cumprimento da sentença ${ }^{292}$.

Os juízes, portanto, recebem uma dupla responsabilidade dos demais Poderes: a primeira, a de responder aos anseios da sociedade, postos à apreciação em ações judiciais que questionam o atuar inadequado ou indiferente dos encarregados pela execução de políticas públicas sociais e; a segunda, de fazer tudo isso sem previsão normativa de técnicas ou soluções possíveis, devendo agir com base somente em sua experiência profissional.

\footnotetext{
$291 \quad$ "La gradualidad progresiva en la satisfacción de los derechos fundamentales en juego, y el escalonamiento de las decisiones, supone el reconocimiento de la imprescindible búsqueda de soluciones consensuadas con los poderes políticos. Tanto como la admisión, al cabo, de que aún la satisfacción de los derechos fundamentales económicos y sociales (DESC), ha de asociarse al establecimiento de las necesarias prioridades presupuestarias. Con lo que la puja entre los poderes se traslada a este escenario. En último análisis, de la adjudicación de los fondos por el Congreso o el PE depende la satisfacción de los derechos conculcados. De ahí que la cuestión esencial, a esa altura, sea hasta dónde puede llegar la presión de los jueces para obligar a los poderes políticos al cumplimiento de deberes que emanan de la Constitución". BERIZONCE, Roberto Omar. Activismo Judicial y Participación en la Construcción de las Políticas Disponível em: http:/ /www.civilprocedurereview.com/busca/baixa_arquivo.php?id=24\&embedded=true.
} 
No Brasil, ainda se vê muita resistência à atuação do Poder Judiciário na formulação de políticas públicas, sendo aceita sua intervenção em momentos menos complexos, como na cobrança da autoridade responsável por uma determinada política pública que tenha sido executada de forma precária, ou mesmo, não executada. Porém, a experiência da Argentina e da Colômbia nos mostra que o Judiciário pode atuar, de forma satisfatória, no planejamento de políticas públicas sociais.

\subsection{Experiência argentina}

Os tribunais argentinos consolidaram em sua jurisprudência um glossário com as principais situações que lhes são apresentadas em sede de controle de políticas públicas. Porém, diferentemente do Brasil, as Cortes argentinas verificam não apenas a constitucionalidade e legalidade da execução das políticas, mas também o seu planejamento.

Dentro das linhas gerais traçadas, os casos apreciados são os seguintes: (i) Intervenções que visam a transformar uma política pública discricionária em obrigatória; (ii) intervenções nas quais o judiciário analisa a constitucionalidade e a legalidade de determinada política pública, além de sua aptidão para satisfazer o direito tutelado. Nesse caso, sendo detectada a incompatibilidade, o Judiciário somente expede instrução às autoridades responsáveis para que reformulem a política pública questionada; (iii) intervenções fundadas na omissão das autoridades responsáveis, em que haja somente uma única medida de política pública adequada, que acaba sendo determinada pelo próprio Judiciário e; (iv) intervenções nas quais o tribunal se limita a declarar a inconstitucionalidade da omissão estatal, sem disposição de qualquer medida reparadora ou sancionatória, que visa somente a servir como mecanismo de pressão ${ }^{293}$.

Identificada a situação em que se enquadra um novo processo, os tribunais já conseguem distinguir melhor as técnicas e procedimentos que precisam ser utilizados. Assim como no Brasil, esse acervo instrumental não é dado pelo legislador, mas sim construído pelo Judiciário $^{294}$, desde a Corte Suprema até os juízos monocráticos ${ }^{295}$.

\section{BERIZONCE. 2013. 138.}

294 "Lo ha hecho en ejercicio de potestades reglamentarias, por medio de acordadas generales -así, el régimen de audiencias públicas (acordada 30/2007) y la intervención de los "amigos del tribunal", en los conflictos en que se debatan cuestiones de trascendencia colectiva o interés general, con la finalidad de ampliar el debate judicial habilitando nuevos espacios de participación social, lo que contribuye a legitimar la 
No caso conhecido como Beatriz Mendoza, a Suprema Corte Argentina teve que lidar com um processo de litisconsórcio misto multitudinário, tendo no polo ativo a presença de diversos indivíduos, associações ambientalistas e o Defensor Público da Nação e, no polo passivo, o Estado Nacional, a Província de Buenos Aires, a Cidade de Buenos Aires e um grupo de quarenta e quatro empresas acusadas de contaminar o Rio Matanza/Riachuelo. Durante a instrução processual, a Corte se valeu livremente de seus poderes ordenatórios e instrutórios, de acordo com os comentários de Roberto Berizonce ${ }^{296}$, tendo solicitado aos entes públicos a apresentação de um plano integrado com prazos peremptórios, que dispusesse do tratamento do manancial de forma progressiva, segundo metas e cronogramas disponibilizados, em respeito à discricionariedade da Administração. Em relação à Agência responsável pela bacia do rio, foram estabelecidos diversos tópicos para cumprimento, dentro os quais o estabelecimento de um plano emergencial de saneamento. Além disso, a Corte designou um juízo próprio para acompanhamento da execução da decisão proferida, além de ter criado um grupo de trabalho composto por ONGs e pelo Ombudsman nacional $^{297}$.

actuación de los jueces. También, en los casos singulares, por medio de creación pretoriana, particularmente en ejercicio de las potestades de conducción y ordenación de las causas, tanto como de su instrucción probatoria, con especial énfasis en la búsqueda de soluciones concertadas e igualmente al tiempo del cumplimiento de sus pronunciamientos". BERIZONCE. 2013. P. 138.

295 "Con la plataforma reglada de las audiencias públicas y la participación de los "amigos del tribunal”, la Corte ha modelado por su propia creación diversas técnicas y procedimientos adecuados a la naturaleza y características de los conflictos de interés público o institucional, con la finalidad última de posibilitar el ejercicio de su poder supremo. Claro que lo propio cabe, por regla aunque con las salvedades del caso, a los jueces comunes cuando semejantes conflictos se radican bajo su competencia. En tal sentido, puede afirmarse que viene operando una suerte de saludable efecto de 'derrame'". BERIZONCE. 2013. 139. 296 BERIZONCE. 2013. 140.

297 "In July 2004, a group of residents of the Matanza/Riachuelo basin filed a suit before the Supreme Court of Argentina against the national government, the Province of Buenos Aires, the City of Buenos Aires and 44 companies seeking compensation for damages resulting from pollution of the basin, stoppage of contaminating activities, and a remedy for collective environmental damage. In July 2008, the Court issued a decision in which it required the national government, the Province of Buenos Aires and the City of Buenos Aires to take measures to improve the residents' quality of life, remedy the environmental damage and prevent future damage. The Court established an action plan requiring the government agency responsible for the Matanza/Riachuelo basin, ACUMAR[1], to fulfill specific measures, including: a) producing and disseminating public information; b) controlling industrial pollution; c) cleaning up waste dumps; d) expanding water supply, sewer and drainage works; e) developing an emergency sanitation plan; f) adopting an international measurement system to assess compliance with the plans goals. In order to ensure adequate enforcement, the Court delegated the enforcement process to a federal court, Juzgado Federal de Primera Instancia de Quilmes, to monitor enforcement of the decision. Furthermore, the Court created a working group formed by the national Ombudsman and the NGOs[2] that had been involved in the case as nonlitigant parties, seeking to strengthen and enable citizen participation in monitoring enforcement of the decision". Disponível em: http:/ /www.escr-net.org/docs/i/1469150. 
No julgamento de um amparo coletivo ajuizado pelo CELS (Centro de Estudios Legales y Sociales), em razão de problemas decorrentes de superlotação do sistema carcerário da Província de Buenos Aires, a Corte adotou diversas medidas para qualificar o diálogo entre as partes para que elas pudessem chegar às soluções mais efetivas, dentre elas a organização de uma mesa de diálogo formada não apenas pelas partes, mas também por diversas outras organizações nacionais e internacionais que se habilitaram como amicus curiae. Além da formação da mesa, o Judiciário ainda expediu comunicação aos Poderes Legislativo e Executivo para que pudessem adequar a legislação a legislação de execução penal aos padrões mínimos estabelecidos pela comunidade internacional ${ }^{298}$.

Vê-se que a justiça argentina tem adotado medidas pouco ortodoxas na busca por soluções consensuais e dialogadas, sem utilização do enforcement como principal característica da jurisdição em processos de interesse público. O procedimento é adaptado pelo Judiciário conforme os contornos exibidos, sempre com respeito ao amplo contraditório, à maior publicidade possível de todo procedimento e não apenas das decisões e aos limites estruturais da Administração. O maior produtor de técnicas processuais é a Corte Suprema, porém, com indicativos de replicação e mesmo de criação de outras ferramentas pelos juízos monocráticos.

\subsection{Experiência colombiana}

Diversamente da tradição de controle de políticas públicas instalada no Brasil, a Colômbia exibe um histórico plural e multifacetado, com intervenções judiciais nos mais diversos assuntos da sociedade e de forma bastante marcada no histórico político recente do País.

De acordo com Rodrigo Uprimny Yepes, são cincos os principais assuntos tratados pela justiça colombiana e que afetam, diretamente, na política nacional: (i) a luta contra a corrupção política e pela transformação das práticas políticas; (ii) o controle dos excessos governamentais, especialmente as declarações de estado de exceção; (iii) a proteção de grupos minoritários e da autonomia individual; (iv) a proteção de populações estigmatizadas ou em situação de debilidade manifesta e; (v) o manejo da política econômica, devido à proteção judicial aos direitos sociais. 
A luta contra a corrupção foi um dos assuntos precursores na judicialização da política na Colômbia. Dentre os exemplos mais significativos desse movimento, tem-se a movimentação em torno do Presidente Ernesto Samper, acusado de utilizar dinheiro do narcotráfico para eleger-se e os processos de perda de investidura (perdida de investidura) que, diferentemente da pena de suspensão dos direitos políticos adotada no Brasil (v.g. art. 12 da Lei 8429/92), afasta o condenado definitivamente da vida política.

As declarações de estado de exceção passaram a ser objeto de controle a partir da promulgação da Constituição de 91, já que entre 1949 a 1991 a Colômbia esteve por 35 anos sob estado de sítio. Em virtude dos excessos cometidos a Corte Suprema passou a exercer um controle material sobre essas declarações, tendo, no período compreendido entre 1992 a 2002, anulado três declarações e validado parcialmente quatro, dentre um total de doze declarações feitas no período ${ }^{299}$.

Apesar da complexidade e da dificuldade operacional dessas atuações, o desempenho mais marcante da justiça colombiana é no campo dos direitos sociais ${ }^{300}$. Nesse campo, a Corte Constitucional foi capaz de elaborar uma verdadeira doutrina para definir a continuidade da omissão da Administração em relação a determinados setores da política nacional, que é a doutrina do estado de coisas inconstitucional ${ }^{301}$. Muitas vezes, a omissão ou inadequação de uma política pública não pode ser debitada na conta do atual gestor, uma vez que seja clara a perpetuação dessa falha estrutural por várias administrações. Há, portanto, uma violação sistemática a direitos fundamentais que passa a ser notada e conduzida para uma ação judicial (processo de interesse público).

299 YEPES, Rodrigo U. La judicialización de la política en Colombia: casos, potencialidades y riesgos. In: PALACIO, Juan Manuel; CANDIOTI, Magdalena [comp]. Justicia, política y derechos en América Latina. Buenos Aires: Prometeo, 2007. p. 48.

300 "En Colombia la tutela de los DESC fue evolucionando en la jurisprudencia a través de la interpretación extensiva del art. 4 de la ley 472/78, de acciones populares o de grupo para la tutela de los derechos colectivos. Así el Consejo de Estado ha protegido, entre otros, el derecho a la salud y el derecho a la educación, como prerrogativas de la prestación de un servicio público". BERIZONCE. 2013. p. 4, nota 4.

301 "El Estado de Cosas Inconstitucional, es un conjunto de hechos, acciones u omisiones que dan como resultado una violación masiva de los derechos fundamentales. Estos hechos pueden emanar de una autoridad pública específica que vulnera de manera constante los derechos fundamentales, o de una problema estructural que no sólo compromete una autoridad en particular sino que incluye consigo la organización y funcionamiento del Estado, y que por tanto se puede calificar como una política pública, de donde nazca la violación generalizada de los derechos fundamentales". RÍOS, Luiz Carlos Alzate. El Estado de Cosas Inconstitucional. Disponível em: http:/ /www.egov.ufsc.br/portal/conteudo/el-estado-de-cosasinconstitucional 
Embora a Corte Suprema da Colômbia seja pródiga em exemplos de enorme riqueza analítica, alguns se destacam como leading cases em relação à doutrina do estado de coisas inconstitucional. Na sentença SU 559/97, foram apreciados pedidos de tutela de professores da rede municipal dos municípios de María la Baja y Zambrano, que alegavam a violação de direito à saúde por parte dos Prefeitos, uma vez que não haviam sido inseridos no Fondo Nacional de Prestaciones Sociales del Magisterio. Ao apreciar os argumentos de ambas as partes, analisar dados orçamentários e estruturais, a Corte verificou tratar-se de um problema geral que afeta um número significativo de docentes no país e cujas causas se relacionam com a execução desordenada e irracional da política educativa; no entanto, a ação de tutela compromete a dois municípios que por falta de recursos não deram cumprimento às suas obrigações para com os autores da ação ${ }^{302}$.

Esse caso não é propriamente notável por suas particularidades processuais, mas foi um dos primeiros em que a Corte Suprema demonstrou que o controle de políticas públicas deve ter em consideração a existência de falhas estruturais que não podem ser corrigidas senão de forma gradual e progressiva.

Outro caso em que a Corte identificou a existência de um estado de coisas inconstitucional e precisou dispor de diversas técnicas para solucioná-lo foi o da sentença T-025/04, em que foi analisada a questão do deslocamento forçado de populações - problema frequente na Colômbia. Inicialmente, a Corte já destaca que em virtude da condição da maioria das pessoas deslocadas (mulheres cabeça da família, menores de idade, minorias étnicas e pessoas de terceira idade), eles não precisariam ser representados por advogados e tão somente pelas associações de deslocados, desde que atendidas determinadas condições ${ }^{303}$.

\footnotetext{
$302 \quad$ “30. De acuerdo a lo expuesto, la situación planteada por los actores tiene que examinarse desde una doble perspectiva. De una parte, se trata de un problema general que afecta a un número significativo de docentes en el país y cuyas causas se relacionan con la ejecución desordenada e irracional de la política educativa. De otra parte, la acción de tutela compromete a dos municipios que por falta de recursos no han dado cumplimiento efectivo a sus obligaciones frente a los educadores que han instaurado la acción de tutela". COLOMBIA. Corte Suprema de Justicia. Sentencia SU 559-97 Disponível em: http://www.corteconstitucional.gov.co/relatoria/1997/SU559-97.htm.

"Tales organizaciones estarán legitimadas para presentar acciones de tutela a favor de sus miembros bajo las siguientes condiciones: 1) que se haga a través de su representante legal, acreditando debidamente su existencia y representación dentro del proceso de tutela; 2) que se individualice, mediante una lista o un escrito, el nombre de los miembros de la asociación a favor de quienes se promueve la acción de tutela; y 3) que no se deduzca de los elementos probatorios que obran en el proceso que el agenciado no quiere que la acción se interponga en su nombre". COLOMBIA. Corte Suprema de Justicia. Sentencia T025/04. Disponível em: http:/ /www.corteconstitucional.gov.co/relatoria/2004/t-025-04.htm
} 
Em razão da multiplicidade de direitos violados, a Corte entendeu que os demandantes teriam direito a atendimento prioritário e adotou as seguintes medidas: (i) foi expedida comunicação ao Conselho Nacional de Atenção da População Deslocada, para que fosse determinada uma forma de superar a insuficiência de recursos e a falência da capacidade institucional, com anotação de prazo para realização do esforço orçamentário necessário. Além disso, foi requerido que esse Conselho indicasse de que forma poderiam contribuir a Nação, as entidades territoriais e a cooperação internacional; (ii) as autoridades responsáveis foram notificadas da decisão; (iii) foi estabelecido que se após a fixação das pautas orçamentárias pelo Conselho de Atenção à População Deslocada, o Conselho concluísse pela impossibilidade de cumprimento dos compromissos assumidos pela política estatal, estes poderiam ser redefinidos, desde que adequados às obrigações jurídicas definidas mediante processos democráticos pelas autoridades competentes, destinadas a cumpri-las.

Como se vê, a aplicação dos princípios da adequação e adaptação aos processos de interesse público já encontra espaço considerável no cotidiano da Corte Suprema da Colômbia. Curiosamente, em ambos os países foi possível identificar a provocação direta feita pelo Poder Judiciário aos Poderes Executivo e Legislativo, para que estes promovessem adequações necessárias à legislação vigente. Logo, a adaptação tem precedido a adequação.

\subsubsection{Os princípios dispositivo e da imparcialidade do juízo como limitadores dos poderes do juiz}

Muito da resistência apresentada ao desempenho de um papel mais ativo pelos magistrados deriva da acusação de parcialidade que o ativismo pode gerar. Em nome do princípio da imparcialidade do juiz, frequentemente exige-se deste uma postura atávica desconectada da moderna compreensão acerca do processo. Sem precisar recorrer às releituras já promovidas pelos processualistas atuais, com objetivo de atualizar as técnicas processuais, Carlos Alberto de Salles afirma que o processo por si só, com suas estruturas tradicionais é capaz de produzir consequências que não podem ser consideradas neutras em relação às expectativas das partes e ao seu próprio objeto ${ }^{304}$.

304 "Na verdade, o processo, ao ordenar a forma como se põe em andamento o sistema jurisdicional, e como este responde às situações que lhe são endereçadas, traz consequências, para as partes ou para terceiros, que longe estão de poderem ser consideradas neutras em relação às expectativas pessoais das partes e aos 
O mito da neutralidade não pode ser exigido nem mesmo da previsão legal abstrata e genérica $^{305}$. Porém, como conseguir que o juiz possa manifestar uma postura mais ativa, sem que isso quebre seu dever de imparcialidade - no sentido de evitar favorecimentos indesejáveis às partes ou contato pernicioso com o objeto do processo ${ }^{306}$ ?

\subsubsection{Princípio da imparcialidade}

A ideia que temos de imparcialidade é sempre vinculada à concepção subjetiva, decorrente do afastamento pessoal do juiz com as partes do processo, de forma que não busque o favorecimento de qualquer uma delas, seja por interesses pessoais ou por opiniões e sentimentos pessoais bastante vinculados ao deslinde da questão - o que difere substancialmente da formação do entendimento de um magistrado sobre determinadas matérias por ele já julgadas ou estudadas. Trata-se de tendências pessoais e não acadêmicas ou profissionais. Daí a grande dificuldade sempre presente de produção de provas que atestem a parcialidade do juiz ${ }^{307}$.

Há, porém, a imparcialidade objetiva do juiz que está ligada à inexistência de manifestação prévia do magistrado acerca dos fatos a serem apreciados em um julgamento. Como bem destaca Gustavo Badaró, essa vertente da imparcialidade “deriva não da relação do juiz

objetivos sociais implicados nas várias espécies de direito material, objeto da adjudicação". SALLES. 2003. p. 53.

Há quem chegue ao extremo de afirmar que "não há imparcialidade, neutralidade e, de conseqüência, perfeição na figura do juiz, que é um homem normal e, como todos outros, sujeito de sua sociedade e à sua própria história". COUTINHO, Jacinto Nelson de Miranda. O novo papel do juiz no processo penal. In: COUTINHO, Jacinto Nelson de Miranda [coord.]. Crítica à Teoria Geral do Direito Processual Penal. Rio de Janeiro-São Paulo: Editora Renovar, 2001. p. 15.

306 A compreensão acerca de uma imparcialidade objetiva e subjetiva decorre de influência de julgados da Corte Europeia de Direitos do Homem. Nesse sentido, "traditionnellement, la partialité, c'est le parti-pris et, par extension, le préjugé. D’où, sous l'influence de la Cour européene des droits de l'homme, le développement d'une conception extensive de l'impartialité, dans deux directions, celle de l'impartialité subjective et celle de l'impartialité objective tenant, la première À la personne même du juge (d'où la référence, parfois, à l'ímpartialité personnelle) et, la seconde, aux fonction qu'il exerce ou a exercé dans une même affaire (d'où l'on parle aussi d'impartialité fonctionnelle)". CADIET, Loïc. Théorie Générale du Procès. Paris: Presses Universitaires de France, 2010. P. 598.

307 "Il n'est pas facile d'apporter la preuve de la partialité subjective d'un juge car c'est sonder les coeurs et les reins. Cette preuve est parfois facilitée par le comportement même du juge qui, par exemple, a exprime, avant le jugement, une opinion ou des sentimento manifestant um a priori à l'encontre de l'une des parties [...] A défaut, le recours à um certain nombre d'indices permet de présumer la partialité du juge, ainsi que la liste des cas de récusation em offre le tableau dans um certain nombre de contentieux: le juge a um intérêt personnel, direct ou indirect, à l'affaire [...]”. CADIET. Obra citada. pp. 598-9. 
com as partes, mas de sua prévia relação com o objeto do processo" ${ }^{\text {308 }}$, estando, por isso, mais vinculada à aparência que à própria realidade ${ }^{309}$.

Decorre disso que a atuação do juiz deve possuir balizas formais para garantia da condução de um processo com lisura e probidade ${ }^{310}$, daí porque a opção por um sistema procedimental rígido. Porém, a concessão de poderes ao juiz que extrapolem sua atividade costumeiramente definida nos manuais de direito processual tem ocorrido com frequência cada vez maior. Nas causas cíveis em que houver preponderância do interesse público sobre o privado, a atividade instrutória do juiz é ampliada, tornando-se independente da obediência ao impulso das partes ${ }^{311}$. Deve-se admitir, pois, que o processo civil brasileiro optou por abandonar o rigor absoluto do princípio dispositivo, tendo-o temperado com autorizações ao juiz para livre investigação ${ }^{312}$.

\subsubsection{Princípio dispositivo}

A compreensão acerca da violação do princípio dispositivo pela concessão de mais poderes ao juiz somente é possível mediante sua anterior definição. Seu conceito exibe vagueza prejudicial ao trabalho científico. A doutrina processual alemã divide o conteúdo que o princípio dispositivo costuma encerrar em si em dois momentos: propositura da demanda e

308 BADARÓ, Gustavo. Direito a um julgamento por juiz imparcial: como assegurar a imparcialidade objetiva do juiz nos sistemas em que não há a função do juiz de garantias. In: BONATO, Gilson. [org]). Processo Penal, Constituição e Crítica Estudos em Homenagem ao Prof. Dr. Jacinto Nelson de Miranda Coutinho. 1ed.Rio de Janeiro: Lumen Juris, 2011.

309 "Avec l'impartialité objective, ce qui est compte, c'est moins la réalité que l'apparence, susceptible d'alimenter un soupçon de partialité. L'idée est que la justice ne doit pas seulement être impartiale; ele doit aussi donner l'apparence qu'elle l'est réellement". CADIET. Obra citada. p. 599.

$310 \quad$ "A imparcialidade do juiz é uma garantia de legalidade e de justiça, válida para o Estado e para as partes. Estas têm o direito de exigir um juiz imparcial: e o Estado, que reservou para si o exercício da função jurisdicional, tem o correspondente dever de agir com imparcialidade na solução das causas que lhe são submetidas". GRINOVER. 2013. p. 13.

311 "quando a causa não-penal versa sobre relações jurídicas em que o interesse público prevalece sobre o privado, não há concessões à verdade formal. Nas causas versando direito de família ou infortunística, de longa data se faz presente o órgão do Ministério Público e o juiz não está vinculado ao impulso das partes" GRINOVER, Ada Pellegrini; DINAMARCO, Cândido Rangel; CINTRA, Antônio Carlos de Araújo. Obra citada. p. 65.

312 "O Código de Processo Civil não só manteve a tendência publicista, que abandonara o rigor do princípio dispositivo [...] como ainda reforçou os poderes diretivos do magistrado (arts. 125, 130, 131, 330, 342 e 440). O sistema adotado representa uma conciliação do princípio dispositivo com o da livre investigação judicial" GRINOVER, Ada Pellegrini; DINAMARCO, Cândido Rangel; CINTRA, Antônio Carlos de Araújo. Obra citada. p. 66. 
estrutura interna do processo ${ }^{313}$. O primeiro momento passa a ser denominado de princípio da demanda, resguardada a nomenclatura do princípio dispositivo para o segundo ${ }^{314}$.

Essa distinção é aproveitada por José Roberto dos Santos Bedaque, para quem o princípio dispositivo está vinculado à relação jurídica material e não processual ${ }^{315}$. Pode-se dizer, de forma redundante, que a disposição de um direito somente pode ocorrer quando ele for disponível - o que não é o caso do direito processual, considerado ramo do direito público não submetido à esfera de disponibilidade das partes.

Esse poder não afeta o monopólio existente sobre a iniciativa do processo, ainda que o direito material seja de natureza pública ou indisponível. Mesmo nesses casos, sustenta Bedaque, "persiste o princípio da inércia da jurisdição"316. Uma vez instaurada a demanda, a relação jurídica processual é desenvolvida de acordo com as técnicas necessárias para resolução do conflito. Importa dizer que o instrumental disponibilizado às partes deve ser adaptado, como já visto anteriormente, de acordo com a natureza do direito material que se pretenda tutelar, atraindo o princípio dispositivo conforme a vontade das partes, que podem renunciar, desistir e reconhecer direitos, moldando os limites de atuação do juiz.

O juiz não se submete, porém, aos meios de prova solicitados por autor e réu. Sua atividade instrutória é plena "à luz dos fatos deduzidos pelas partes"317. Dentro dos limites objetivos traçados pelas partes, a cognição judicial deve ser exauriente, não podendo, por esse motivo, estar submetida a travas impostas pelas partes que conduzam a um julgamento parcial, às escuras $^{318}$.

313 BEDAQUE, José Roberto dos Santos. Poderes Instrutórios do Juiz. 4. ed. rev. atual. amp. São Paulo: RT, 2009. p. 88.

$314 \quad$ BEDAQUE. 2009. p. 90.

315 BEDAQUE. 2009. p. 91: "preferível que a denominação 'princípio dispositivo' seja reservada tãosomente aos reflexos que a relação de direito material disponível possa produzir no processo. E tais reflexos referem-se apenas à relação jurídico-substancial. Assim, tratando-se de direito disponível, as partes têm ampla liberdade para dele dispor, através de atos processuais (renúncia, desistência, reconhecimento do pedido). E não pode o juiz opor-se à prática de tais atos, exatamente em virtude da natureza do direito material em questão. Essa sim corresponde à verdadeira e adequada manifestação do princípio dispositivo. Trata-se de um princípio relativo à relação material, não à processual".

316 BEDAQUE. 2009. p. 92.

317 BEDAQUE. 2009. p. 95.

318 ARENHART, Sérgio Cruz. Reflexões sobre o princípio da demanda. Disponível em: https://ufpr.academia.edu/SergioCruzArenhart: "O princípio da correlação não se limita a impedir o magistrado de julgar fora do pedido, mas lhe impõe o dever de examinar o pedido em toda sua extensão [...] Desse modo, o princípio da demanda não representa apenas uma garantia negativa - consistente em impedir o juiz de ir além do pedido da parte -, mas, configura também um dever positivo - que impõe a apreciação da totalidade do pedido. 
A desvinculação do juiz do princípio da correlação acontece com maior intensidade no campo das tutelas específicas $^{319}$. Os arts. 461 e 461-A do CPC conferiram ao juiz poderes suficientes para conceder tutelas que, embora não pedidas pelas partes, sirvam ao objetivo demonstrado em suas razões ou, em última instância, sejam capazes de resolver a crise de direito instalada.

Essa atuação quebra a lógica do processo civil forjado pelas estruturas de um estado liberal $^{320}$ e se aproxima das exigências do estado democrático de direito, liberto de padrões individualistas capazes de confinar a atuação do juiz na busca pela realização dos escopos do processo.

\subsubsection{Princípio da demanda}

Embora diga que a natureza do direito material não influencia na manutenção do monopólio da demanda pelos sujeitos dessa relação, José Roberto dos Santos Bedaque admite que existam exceções, assim como Sérgio Cruz Arenhart.

A elevação do princípio da demanda a um verdadeiro axioma do processo civil tem por razão fundante a preservação da imparcialidade do juiz ${ }^{321}$, a mesma que protege e sustenta a integridade do princípio dispositivo. E claro, assim como foi dito acima, existem razões para mitigar o rigor do princípio da demanda como garantia da imparcialidade do juiz.

A realidade social brasileira, permeada historicamente pela pobreza ${ }^{322}$ impede o agir emancipado dos cidadãos. Com a hipossuficiência generalizada, a manutenção de princípios que privilegiem as liberdades individuais - como o da demanda - somente

\footnotetext{
319 Marinoni ao tratar do afastamento do princípio da congruência no campo das tutelas específicas diz "essa proibição [de decidir fora do pedido da parte] tinha que ser minimizada para que o juiz pudesse responder à sua função de dar efetiva tutela aos direitos. Melhor explicando, essa regra não poderia mais prevalecer, de modo absoluto, diante das novas situações de direito substancial e da constatação de que o juiz não pode mais ser visto como um 'inimigo', mas como representante de um Estado que tem consciência que a efetiva proteção dos direitos é fundamental para a justa organização social" MARINONI, Luiz Guilherme. Técnica processual e tutela dos direitos. 3. Ed. São Paulo: RT, 2010. p. 136.

$320 \quad$ BEDAQUE. 2009. p. 98.

321 ARENHART. Obra citada. p 23.

322 ARENHART. Obra citada. p. 25
} 
agrava e fortalece as estruturas oficiais de dominação. Como destacado por Ada Pellegrini Grinover $^{323}$ :

\begin{abstract}
A absoluta igualdade jurídica não pode, contudo, eliminar a desigualdade econômica e institucional: por isso, do primitivo conceito de igualdade formal e negativa (a lei não deve estabelecer qualquer diferença entre os indivíduos), clamou-se pela passagem à igualdade substancial. E hoje, na conceituação positiva da isonomia (iguais oportunidades para todos, a serem propiciadas pelo Estado), realça-se o conceito realista, que pugna pela igualdade proporcional, a qual significa, em síntese, tratamento igual aos substancialmente iguais.
\end{abstract}

No lugar desses princípios de feição individualista, outras técnicas são utilizadas para atingir a igualdade substancial, v.g. (i) contraditório, como espaço de participação dos sujeitos parciais, assegurando o direito de influírem decisivamente no provimento jurisdicional; (ii) o dever constitucional do magistrado de fundamentar suas decisões (art. 93, IX da Constituição), que amplia suas possibilidades de controle ${ }^{324}$; e (iii) a finalidade, que no caso dos processos de controle de políticas públicas, está vinculada ao direito material tutelado. Com observância dessas garantias, fica autorizada a flexibilização pontual do princípio da demanda quando necessária à satisfação dos escopos do processo e à execução dos objetivos fundamentais da República (art. $3^{\circ}$ da Constituição) - como é o caso do processo para controle das políticas públicas sociais ${ }^{325}$.

O contraditório que se exige para esse processo menos individualista deve ser capaz de garantir às partes a oportunidade de convencer o juiz dos argumentos apresentados, ou seja, não é forçoso que o juiz seja persuadido, mas as partes devem ter garantida a oportunidade de tentá-10 ${ }^{326}$. Essa fórmula garante a igualdade entre os litigantes - que passam a atuar no processo com paridade de $\operatorname{armas}^{327}$ - e serve como principal fundamento para a imparcialidade do juiz ${ }^{328}$.

\footnotetext{
323 GRINOVER. 2013. p. 15.

324 Para Ada Pellegrini Grinover, a motivação das decisões não está limitada somente ao dever de fundamentar os provimentos judiciais; mais que isso, ela deve ser "completa, indicando as razões adotadas para a solução de cada uma das questões particulares solucionadas para se chegar à solução final". GRINOVER. 2013. p. 19.

325 ARENHART. Obra citada. p 26-7

326 MARINONI. 2012. P. 227. Ada Pellegrini Grinover, ao abordar o princípio da motivação das decisões judiciais, afirmou que essa exigência "deve ser compreendida à luz do contraditório, até porque as atividades das partes só adquirem significado se forem efetivamente levadas em consideração pelo juiz no momento da decisão. Assim, na motivação o juiz deve dar conta da real consideração de todos os dados trazidos à discussão pelos interessados no provimento". GRINOVER. 2013. p. 20.

327 Busca-se, ainda, dar concretude à igualdade processual que decorre do princípio da isonomia, inscrito no inciso I do art. $5^{\circ}$, - transformando-a no princípio dinâmico da par condicio ou da igualdade de
} 
Em verdade, embora tratados como princípios, por força da consagração do termo pela doutrina processual, os princípios da demanda e o dispositivo, assim como o da correlação são apenas técnicas processuais que alcançaram prestígio junto ao meio jurídico ${ }^{329}$.

Para Cândido Rangel Dinamarco, apenas faz sentido tomar por princípios as estruturas que promovem a conexão do direito processual com os demais ramos do conhecimento jurídico $^{330}$. Sendo essas técnicas estruturas internas do direito processual, elas jamais poderiam ser tomadas por princípios, a exemplo dos consagrados constitucionalmente, quais sejam, inafastabilidade do controle jurisdicional, igualdade, liberdade, contraditório e ampla defesa, juiz natural e publicidade.

Esses princípios formam a base do direito processual constitucional ${ }^{331}$, que não está limitado a um enfoque simplesmente técnico e se abre aos valores emanados da constituição e da sociedade ${ }^{332}$. É essa abertura que permite que o processo seja moldado de forma adequada para conferir efetividade aos direitos fundamentais, que precisam de um veículo para aplicação imediata e não podem ser obstados por uma interpretação cerrada das normas procedimentais ${ }^{333}$.

Os direitos fundamentais, tido por auto-aplicáveis, dependem do processo, como mecanismo imperativo de resolução de controvérsias à disposição do Estado, para serem

armas, mediante o equilíbrio dos litigantes no processo civil, e da acusação e defesa, no processo penal. GRINOVER. 2013. p.. 7.

$328 \quad$ BARACHO. Obra citada. p.54.

329 É claro que, no fundo, a todas essas regras pode-se chegar, com algum esforço de raciocínio, a partir das ideias representadas pelos princípios gerais e políticos do processo, ou seja, a partir de suas premissas externas e fundamentais. Mas, em si mesmas, elas não são verdadeiros princípios do direito processual. DINAMARCO. 2009a. p. 201.

$330 \quad$ DINAMARCO. 2009a. p.202.

331 Segundo Ada Pellegrini Grinover, o direito processual constitucional é “a condensação metodológica e sistemática dos princípios constitucionais do processo”. GRINOVER. 2013. p. 4.

332 "[...] foi surgindo a consciência de que o sistema processual não tem natureza e objetivos puramente técnicos, com a afirmação de sua permeabilidade à ação dos valores tutelados na ordem políticoconstitucional e jurídico-material (os quais buscam efetividade através dele) e com o reconhecimento de sua inserção no universo axiológico da sociedade a que se destina". DINAMARCO, Cândido Rangel. Escopos políticos do processo. In: GRINOVER, Ada Pellegrini; DINAMARCO, Cândido Rangel; WATANABE, Kazuo. [coord.] Participação e Processo. São Paulo: RT, 1988. P. 114.

333 "Os direitos fundamentais vinculam o Legislativo, o Executivo e o Judiciário, e a própria jurisdição, como direitos diretamente aplicáveis. É nesse sentido que a jurisdição, em suas distintas instâncias, em razão das normas constitucionais, está obrigada à imediata aplicação dos direitos fundamentais. As interpretações de uma norma ordinária não podem desconhecer o conteúdo normativo do direito fundamental". BARACHO. Obra citada. p.54. 
efetivados em todos os casos em que se apresente resistência ao seu cumprimento - ainda que pelo próprio Estado ${ }^{334}$.

\subsection{PODERES DO JUIZ}

O descumprimento de uma norma infraconstitucional não passa de mera omissão, ao passo que a inoperância na concretização de direitos fundamentais expressamente previstos na Constituição é entendida pelo ordenamento jurídico como uma omissão qualificada, passível de controle pelo Poder Judiciário ${ }^{335}$, na condição de responsável pela integridade do texto constitucional. A partir dessa permissão, o magistrado passa a exercer papel mais consentâneo com os valores supra indicados, que aproximam o processo civil - agora em relação íntima com a Constituição - aos anseios da sociedade.

Essa não é a primeira vez que o Judiciário é chamado, por força de mudanças radicais na estrutura jurídica, a se posicionar de forma diferente do que estivera acostumado. Se a doutrina tem alertado para as mudanças estruturais no direito e no processo, compete ao magistrado entender que sua postura mais ativa é exigida nesses novos tempos de processo socialmente efetivo $^{336}$. Aos juízes é permitido, inclusive, o exercício da criatividade na interpretação das normas ${ }^{337}$ jurídicas - mas nunca de intervenção no privatístico princípio da demanda, ainda um grande dogma.

334 "A efetividade dos direitos fundamentais ocorre pelos mecanismos de realização jurisdicional dos mesmos. A efetividade ou eficácia dos direitos fundamentais opera-se pela sua aplicabilidade real e concreta. Com isso ocorrem as possibilidades reais de concretização dos direitos fundamentais a todos os cidadãos, por meio da realização e otimização dos mesmos. As normas constitucionais são dirigidas à realidade, daí que a interpretação deve ser orientada para sua efetividade, vigência prática e material’. BARACHO. Obra citada. p..54.

68.

FREIRE JR. Américo Bedê. O Controle Judicial de Políticas Públicas. São Paulo: RT, 2005. P.

336 "Ao mesmo tempo, porém, há de ser revisto o papel a ser desempenhado pelo juiz em um processo renovado e adequado à realidade social contemporânea. A idéia de que 'se é certo que o sucesso das leis depende dos homens, o sucesso das leis processuais depende, antes de mais nada, do juiz', ganha hoje nova atualidade. As grandes revoluções do direito e do processo - como a romana do jus honorarium, a inglesa da equity, a europeia do jus mercatorum - exigiram novos juízes para concretizá-las. E hoje, quando todo o processo civil caminha para uma profunda transformação, o juiz há de saber assumir um papel mais ativo, sem perder sua imparcialidade. Assim deve ser, em um processo comum que se queira célere, social, democrático, assistencial". GRINOVER, Ada Pellegrini. A independência do juiz brasileiro. In: O Processo em sua unidade - II. Rio de Janeiro: Forense, 1984. pp. 53-4.

337 "Não obstante o respeito às normas constitucionais e infraconstitucionais, é certo que sobra grande espaço de criatividade aos juízes na interpretação da lei. E ao interpretar a lei, o juiz estará, na verdade, criando o direito, na medida em que, como observou magistralmente Cappelletti, interpretação e criação do direito não são conceitos contrapostos". CERVONE DE OLIVEIRA, Swarai. Poderes do juiz nas ações coletivas. São Paulo: Atlas, 2009. P. 59. 
A preocupação social do juiz ainda deve levar em consideração o caráter prospectivo de suas decisões, que influenciam futuros julgados - mormente com a aproximação metodológica do ordenamento jurídico brasileiro com as técnicas do common law. Com isso, o peso político das decisões judiciais aumenta de forma considerável e leva o Judiciário a um protagonismo destacado no cenário democrático ${ }^{338}$ - papel declaradamente assumido pelas mais diversas instâncias, mas, em especial, pelo Supremo Tribunal Federal, na qualidade de intérprete institucional por excelência dos comandos constitucionais.

No julgamento da Ação Direta de Descumprimento de Preceito Fundamental no 45/DF, o Ministro Celso de Mello destacou que justamente esse papel político que a Corte representa a obriga a atuar em favor dos direitos econômicos, sociais e culturais. Obviamente, essa atuação não é primária e não concorre com as políticas definidas pelo Executivo e pelo Legislativo ${ }^{339}$; ao contrário, decorre justamente da omissão destes em promover a efetivação daqueles direitos. A gravidade dessa omissão, que constitui violação ao texto constitucional, autoriza a atuação supletiva do Poder Judiciário ${ }^{340}$ como salvaguarda da "aplicabilidade dos postulados e princípios da Lei Fundamental". (RTJ 185/794-796, Rel. Min. CELSO DE MELLO, Pleno).

A postura mais ativa do magistrado, embora ainda possa ser vista com desconfiança por alguns juristas, já encontra, como visto, respaldo da própria jurisprudência dos tribunais brasileiros acerca do tema do controle de políticas públicas. O Judiciário, em demandas dessa natureza, tem se permitido adotar medidas audaciosas, sem incidir, na concepção do $\mathrm{STF}$, em violação ao princípio da separação dos poderes ${ }^{341}$. Bloqueio de verbas e bens

\footnotetext{
338 CERVONE DE OLIVEIRA. Obra citada. pp. 59-60.

339 Impende assinalar, no entanto, que a incumbência de fazer implementar políticas públicas fundadas na Constituição poderá atribuir-se, ainda que excepcionalmente, ao Judiciário, se e quando os entes e órgãos estatais competentes (como os Municípios, p. ex.), por descumprirem os encargos político-jurídicos que sobre eles incidem em caráter vinculante, vierem a comprometer, com tal comportamento, a eficácia e a integridade de direitos individuais e/ou coletivos impregnados de estatura constitucional, como sucede na espécie ora em exame. BRASIL. Supremo Tribunal Federal. RE 488208, Relator(a): Min. CELSO DE MELLO, julgado em 01/07/2013, publicado em DJe-150 DIVULG 02/08/2013 PUBLIC 05/08/2013.

$340 \quad$ Resulta claro, pois, que o Poder Judiciário dispõe de competência para exercer, no caso concreto, controle de legitimidade sobre a omissão do Estado na implementação de políticas públicas cuja efetivação lhe incumbe por efeito de expressa determinação constitucional, sendo certo, ainda, que, ao assim proceder, o órgão judiciário competente estará agindo dentro dos limites de suas atribuições institucionais, sem incidir em ofensa ao princípio da separação de poderes, tal como tem sido reconhecido, por esta Suprema Corte, em sucessivos julgamentos. BRASIL. Supremo Tribunal Federal. RE 367.432-AgR/PR, Rel. Min. EROS GRAU. BRASIL. Supremo Tribunal Federal. RE 543.397/PR, Rel. Min. EROS GRAU. BRASIL. Supremo Tribunal Federal. RE 556.556/PR, Rel. Min. ELLEN GRACIE, v.g..

341 BRASIL.. Supremo Tribunal Federal. RE 367432 AgR, Relator(a): Min. EROS GRAU, Segunda Turma, julgado em 20/04/2010, DJe-086 DIVULG 13-05-2010 PUBLIC 14-05-2010 EMENT VOL-02401-
} 
públicos $^{342}$, imposição de astreintes à Fazenda Pública ${ }^{343}$, prisão de agentes políticos e outras técncias não tradicionais são autorizadas em decorrência do direito que se pretende tutelar.

São medidas ousadas, tendentes à garantia de maior efetividade aos direitos fundamentais, mas que ainda se confinam aos limites cerrados do processo civil tradicional. As técnicas são novas, mas a ferramenta é desatualizada. Enquanto ideias mais modernas acerca do procedimento não são apreciadas pelo Congresso (a exemplo do Anteprojeto de Controle Judicial de Políticas Públicas redigido pelo CEBEPEJ, referenciado anteriormente), algumas situações podem ser reparadas pelo próprio juiz, de acordo com o princípio da adaptabilidade.

As medidas tendentes ao cumprimento das condenações impostas pelo Judiciário, como visto, já tem sido objeto de olhar criativo dos magistrados brasileiros. Basta agora que sejam compreendidas e aplicadas as questões inerentes às responsabilidades de cada um dos entes federados. Quem deve figurar no polo passivo de um processo judicial cujo objeto seja o controle de políticas públicas?

\subsection{PARTE}

Como expõe Salvatore Satta, o conceito de parte não se confina aos limites do processo, fazendo parte da linguagem comum. Serve para designar os sujeitos de um contrato ou

04 PP-00750; RE 543397, Relator(a): Min. EROS GRAU, julgado em 07/12/2009, publicado em DJe-022 DIVULG 04/02/2010 PUBLIC 05/02/2010; RE 556556, Relator(a): Min. ELLEN GRACIE, julgado em 03/02/2011, publicado em DJe-031 DIVULG 15/02/2011 PUBLIC 16/02/2011; RE 488208, Relator(a): Min. CELSO DE MELLO, julgado em 01/07/2013, publicado em DJe-150 DIVULG 02/08/2013 PUBLIC 05/08/2013. Nesse último: "Na realidade, o Supremo Tribunal Federal, ao suprir as omissões inconstitucionais dos órgãos estatais e ao adotar medidas que objetivem restaurar a Constituição violada pela inércia dos Poderes do Estado, nada mais faz senão cumprir a sua missão institucional e demonstrar, com esse gesto, o respeito incondicional que tem pela autoridade da Lei Fundamental da República. A colmatação de omissões inconstitucionais, realizada em sede jurisdicional, notadamente quando emanada desta Corte Suprema, torna-se uma necessidade institucional, quando os órgãos do Poder Público se omitem ou retardam, excessivamente, o cumprimento de obrigações a que estão sujeitos por expressa determinação do próprio estatuto constitucional, ainda mais se se tiver presente que o Poder Judiciário, tratando-se de comportamentos estatais ofensivos à Constituição, não pode se reduzir a uma posição de pura passividade. As situações configuradoras de omissão inconstitucional - ainda que se cuide de omissão parcial derivada da insuficiente concretização, pelo Poder Público, do conteúdo material da norma impositiva fundada na Carta Política refletem comportamento estatal que deve ser repelido, pois a inércia do Estado qualifica-se como uma das causas geradoras dos processos informais de mudança da Constituição [...]"

${ }_{342}$ BRASIL. Superior Tribunal de Justiça. REsp 1069810/RS, Rel. Ministro NAPOLEÃO NUNES MAIA FILHO, PRIMEIRA SEÇÃO, julgado em 23/10/2013, DJe 06/11/2013.

$343 \quad$ BRASIL. STF. RE 488.208/SC. Rel. Min. CELSO DE MELLO. 
mesmo o protagonista de um conflito, sendo pessoas que possuem interesse pessoal no assunto e com ele desenvolve uma relação composta por outras pessoas, também partes. No direito, as partes possuem uma relação mediada por uma unidade, que seria a norma ${ }^{344}$. Já no processo, essa unidade seria a afirmação da existência do direito (previsto em uma norma) mediante o julgamento ${ }^{345}$.

Para o autor, há interdependência na relação das partes com o processo, que seria decorrente da necessidade de estabelecimento do contraditório. No entanto, nem toda pessoa interessada no julgamento do processo poderia ser parte, conceito aferido, em seu entender, a partir de uma posição jurídica tida em relação julgamento e ao objeto levado a julgamento. Essa posição é que define o interesse ${ }^{346}$.

Ainda de acordo com Salvatore Satta, a determinação do conceito de parte envolve, por vezes, questões de direito material ${ }^{347}$ ou, melhor dizendo, parte seria aquele frente ao qual é possível concretizar-se a vontade da norma ${ }^{348}$. Muitas vezes, é a própria lei que indica

344 "il concetto di parte non è, come quello di giudice, esclusivo del processo. Nel linguaggio comune, e in quello dela stessa legge, si designano col nome di parti i contraenti di un contrato [...] e in genere $\mathrm{i}$ protagonisti di un qualunque conflito (si pensi al duelo, ala guerra, ai partiti politici). Tutti costoro sono parti indubbiamente perchè si presentano ciascuno come portatore di um interesse e di uma volontà "particolare", in contrasto con la volontà e l'interesse no meno "particolare" dell'altro. Ma non bastala particolarità degli interessi, per dar ragione dell'idea che è nella parola "parte". Parte infatti indica uma relazione, e non con un'altra parte, ma con un tutto, con l'unità. Quei soggetti che chiamiamo parti sono tali proprio in relazione all'unità verso la quale tendono, e nella quale esse si resolvono. Questa unità è essenzialmente la norma (sia che venga concordata, col contratto, o imposta, con la vittoria nella lotta)". SATTA, Salvatore. Diritto processuale civile. 6. Ed. Riv. Cor. Padova: CEDAM, 1959a. p. 68.

345 "Il concetto di parte è dunque in funzione di un divenire, e di un divenire per opera delle parti stesse: ed è per questo che noi troviamo nel processo le parti, perchè il processo non è altro, per definizione, che un divenire. Ma, a differenza delle ipotesi sopra indicate, la norma che attraverso il processo si cerca e si afferma non è opera delle parti: non sono cioè esse che la convengono o la impongono. Essa anzi non viene nemmeno formalmente creata, perchè già esiste: si tratta solo di affermare che esiste, cioè di compiere un giudizio. L'unità verso la quale le parti tendono e nella quale i loro interessi si risolvono è dunque il giudizio". SATTA. 1959a. p. 68.

346 "Che queste parti debbano partecipare (formalmente) al giudizio è canone di antica esperienza, il quale è stato ben riassunto nella formula: 'se il processo è necessario alle parti, le parti sono necessarie al processo'. Il principio del contradittorio ha molte giustificazioni, e questa non è una delle meno profonde. Il problema è però risolto solo a metà, perchè coloro che hanno interesse a che sia giudicato 'in un certo modo' in ordine a una determinata fattispecie possono essere innumerevoli, comunque sono indefiniti. Basta considerare l'interesse come motivo di recusazione del giudice per rendersene conto. La soluzione può però ricavarsi dall'art. 81 del codice, il quale dice che nessuno può far valere nel processo in nome proprio un diritto altrui. Questo implica che, per acquistare la qualità di parte occorre avere una certa posizione giuridica rispetto al giudizio e all’oggetto del giudizio. L'interesse è determinato da questa posizione giuridica, ed esclusivamente da essa". SATTA. 1959a. p. 69.

347 "La determinazione della parte implica spesso questioni di diritto sostanziale [...]" SATTA. 1959a. p. 69. p. 70 .

"parte cioè deve essere colui nei cui confronti si concreta la volontá della norma”. SATTA. 1959a. 
contra quem deve ser proposta a demanda, especialmente nas situações em que haja pluralidade de partes $^{349}$.

O conceito de parte apresentado por Salvatore Satta, como se vê, não distingue parte da justa parte ou parte legítima. Em contraposição, Cândido Rangel Dinamarco apresenta o conceito de parte mais aceito pela doutrina processual. Com apoio na doutrina de Liebman, afirma que partes seriam os sujeitos do contraditório instituído perante o juiz, que atuam em todas as fases do processo com interesse na obtenção de um provimento definitivo ${ }^{350}$. Esse seria um conceito definido como puro $^{351}$, decorrente apenas da inclusão de alguém em uma relação jurídica processual, independentemente de sua pertinência como relação de direito material apresentada no processo.

Para Salvatore Satta, a separação conceitual entre parte e justa parte seria decorrente de um equívoco, originado na divisão entre posição processual e posição material. $\mathrm{O}$ autor, ao demandar, afirma sua própria legitimação ao tempo em que pleiteia o reconhecimento e a tutela de seu interesse apresentado em juízo, razão pela qual será sempre parte e justa parte. Sendo o caso de o juiz reconhecer que o direito deduzido em juízo não lhe pertence ou não é reconhecido pelo ordenamento, a demanda será extinta por esse fato e não porque a parte não seja a justa parte ${ }^{352}$.

\footnotetext{
349 "Spesso è la legge stessa che indica chi sia il soggeto passivo dell'azione, specie quando imponga una pluralità di soggeti". SATTA. 1959a. p. 70.

$350 \quad$ "Partes são os sujeitos interessados da relação processual, ou os sujeitos do contraditório instituído perante o juiz (Liebman). Dizem-se interessados porque ali estão sempre em defesa de alguma pretensão própria ou alheia, em preparação para receberem os efeitos do provimento final do processo. Elas participam dos combates inerentes a este e beneficiar-se-ão com seus efeitos substanciais diretos ou indiretos, ou os suportarão". DINAMARCO, Cândido Rangel. Instituições de Direito Processual Civil. v. II. 6. ed. rev. atual. São Paulo: Malheiros, 2009b. p. 252.

351 "Esse é o conceito puro de parte, ou puramente processual. Apóia-se exclusivamente no fato objetivo de a pessoa estar incluída em uma relação processual como seu sujeito parcial e ali estar em defesa de alguma pretensão". DINAMARCO, 2009b. p. 253.

352 "La pretesa scissione della parte dalla giusta parte è frutto di un equivoco, e precisamente della arbitraria distinzione fra posizione processuali e posizione sostanziali della parte. In realtà chi domanda, e per ciò solo chi domanda, afferma la propria legittimazione, cioè postula che l'ordinamento giuridico riconosce $\mathrm{e}$ tutela come suo l'interesse che vuol far valere. Egli è quindi sempre parte e giusta parte, o per meglio dire non ha senso distinguere in lui la parte dalla giusta parte. Che se poi il giudice gli dice che l'interesse che egli vuol far valere non è suo, ma è di un altro, o comunque non è riconosciuto dall'ordinamento [...] la sua domanda sarà respinta proprio per questo, e non perchè egli pur essendo parte, non è la giusta parte". SATTA. 1959a. p. 71.
} 
Após abordar a concepção chiovendiana acerca da precedência da ideia de parte à de parte legítima $^{353}$, Salvatore Satta protesta contra a redução da parte a uma mera figura processual, quando a própria lei, em diversas hipóteses fala em parte no sentido de justa $\operatorname{parte}^{354}$.

Para Cândido Rangel Dinamarco, porém, a posição que o sujeito ocupa em uma relação jurídica material é irrelevante para o conceito de parte processual. Isso porque, a relação jurídica material se desenvolve em torno de direitos e obrigações inerentes a um bem da vida, sendo uma esfera jurídica diversa da constituída no processo $^{355}$.

As partes do processo são, além do Estado-Juiz, autor e réu ${ }^{356}$, sendo o autor aquele que pleiteia determinado bem da vida em juízo e o réu aquele contra quem esse pleito é dirigido, independentemente da pertinência desses com o direito material objeto da demanda. A relação jurídica processual se distingue da material: “(a) pelos seus sujeitos (autor, réu e Estado-juiz); (b) pelo seu objeto (a prestação jurisdicional); (c) pelos seus pressupostos (os pressupostos processuais)" 357.

Em contrapartida, a partes legítimas seriam aquelas a quem a lei autoriza expressamente a promoção da "defesa de direitos e interesses, seja propondo a demanda, seja para que em

\footnotetext{
353 "Comunque sia, è però indubitabile dalla formula di Chiovenda, bene o malamente intesa che sia, si fa discendere il corollario che la parte è un prius rispetto alla legittimazione, cioè che la questione della legittimazione, della giusta parte, sorge rispetto alla parte già costituita, individuata in base alla sola domanda, che cioè è parte anche quel soggetto alla cui domanda il giudice risponde che non è la giusta parte. A tutte queste posizioni concettuali fanno da sostegno alcuno dati di diritto e di fatto che si enunciano dai sostenitori di esse: particolarmente che nessun effeto del processo si produce nei confronti della giusta parte che non sia anche parte in causa, cioè attrice o convenuta con la domanda, mentre per converso nei confronti della parte in giudizio, anche non giusta, si producono indubitabili effeti quali ad es. La condanna nelle spese, e più in generale è lei che diventa soggetto dei poteri e degli oneri processuali, non già la giusta parte". SATTA, Salvatore. Commentario al codice di procedura civile. Libro primo. Milão: Casa Editrice Dr. Francesco Vallardi, 1959b. pp. 250

$354 \quad$ "Questa riduzione della parte a una mera figura processuale, e ben si protrebbe dire, a una mera figura, se parte è colui che chiede anche quando non ha nulla da chiedere, o in bizzarra ipotesi anche quando non chiede nulla, pur che proponga un atto formale di introduzione di giudizio non poteva non lasciare un certo margine di perplessità, tanto più che in varie ipotesi, la legge quando parla di parte fa evidente riferimento alla giusta parte [...]". SATTA. 1959b. pp. 250-1

355 "Para conceituação da parte processual não tem a menor relevância a posição do sujeito em face do direito material nem sua condição de parte legítima ou ilegítima. Partes na relação jurídica material são os titulares de direitos e obrigações referentes a um bem da vida, como os sujeitos que celebram um contrato ou o que causou o dano e o que o sofreu, os cônjuges em face do vínculo matrimonial etc". DINAMARCO. 2009b. p. 253.

356 "Fala-se aqui em autor e réu, como de resto é usual na doutrina embora tais vocábulos só sejam adequados para designar os sujeitos parciais do processo de conhecimento e cautelar.". GRINOVER, DINAMARCO. CINTRA. Obra citada. p. 295.

357 GRINOVER, DINAMARCO. CINTRA. Obra citada. p. 280.
} 


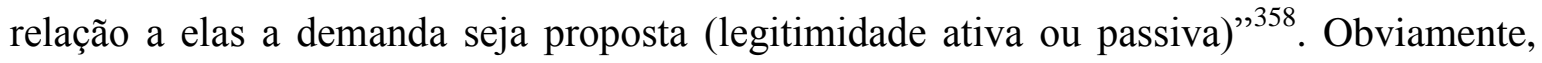
espera-se que na prática haja coincidência, sendo as partes da relação jurídica processual as mesmas presentes na relação material. No entanto, em não havendo essa coincidência, os sujeitos processuais continuam sendo partes, porém ilegítimas, o que redunda na extinção da demanda sem resolução do mérito (art. 267, VI do CPC). Esse é o conceito adotado por nosso ordenamento jurídico e aceito por toda a doutrina atual. Não existe confusão entre parte e parte legítima ${ }^{359}$.

\subsection{LEGITIMIDADE}

A legitimidade ad causam (uma das condições da ação) sempre foi apresentada como a identificação do sujeito inserido em uma relação jurídica processual com a crise de direito nela veiculada ${ }^{360}$, sendo possível afirmar que o legitimado seria aquele que sofreria os efeitos, positivos ou negativos, do resultado da demanda. Para Cândido Rangel Dinamarco, "sempre que a procedência de uma demanda seja apta a melhorar o patrimônio ou a vida do autor, ele será parte legítima; sempre que ela for apta a atuar sobre a vida ou patrimônio do réu, também esse será parte legítima" ${ }^{361}$. Tem-se, sumariamente apresentado, o conceito da legitimidade ad causam ordinária, prevista na primeira parte do art. $6^{\circ}$ do $\mathrm{CPC}^{362}$.

Há, no entanto, a possibilidade excepcional de pessoa física ou jurídica ser autorizada por lei a demandar judicialmente, em nome próprio, direito alheio. Essa previsão está contida na parte final do art. $6^{\circ}$ do $\mathrm{CPC}^{363}$, e é conhecida por legitimidade extraordinária definição que não terá utilidade para o presente trabalho.

Dizer que a legitimidade seria verificada conforme a potencialidade do provimento de produzir seus efeitos sobre a esfera jurídica de determinado indivíduo pode transmitir a ideia de que, por vezes, a conclusão pela sua existência somente ocorrerá após a instrução

\footnotetext{
$358 \quad$ DINAMARCO. 2009b. p. 253.

"A condição objetiva de parte afere-se no plano do ser e a condição ideal de parte legítima, do dever-ser". DINAMARCO. 2009b. p 121.

360 "A legitimidade para agir pergunta sobre a relação de identificação entre o autor e o réu com o direito material em litígio. É legitimado ativo o titular do direito material e legitimado passivo aquele que, também no plano do direito material, contra esse direito pode se opor”. MARINONI. 2012. p. 183.

$361 \quad$ DINAMARCO. 2009b. p. 313.

362 Art. $6^{\circ}$ Ninguém poderá pleitear, em nome próprio, direito alheio [omissis].

363 Art. $6^{\circ}[$ omissis $]$ salvo quando autorizado por lei.
} 
processual, quando o juiz tiver em seu poder provas suficientes da participação daqueles sujeitos (rectius, partes processuais) na crise de direito submetida à sua apreciação.

No entanto, para José Roberto dos Santos Bedaque, um dos maiores defensores da teoria da asserção no Brasil, a legitimidade é passível de verificação mediante análise de alguns $\operatorname{aspectos}^{364}$ apresentados pelo autor quando da propositura da demanda. Somente pela leitura da petição inicial, mediante abstração das possibilidades que possam surgir no curso do processo, sem perquirição da relação jurídica material, o juiz teria condições de proceder ao exame da existência da legitimidade ordinária.

Para Bedaque, também a legitimidade extraordinária poderia ser identificada sem apreciação valorativa acerca da relação material litigiosa, bastando, para isso, que seja possível identificar a autorização legal para que a parte esteja no processo, em nome próprio, na defesa de direito alheio ${ }^{365}$.

Quando não for possível proceder a essa verificação - que, de acordo com Bedaque, se dá na maioria das vezes - o juiz deverá analisar a relação de direito material para descubrir se as partes processuais "ocupam, na situação legitimante, posições que justificam sua inclusão nos polos ativo e passivo do processo",366.

Verifica-se, portanto, que José Roberto dos Santos Bedaque opta por um conceito de legitimidade que decorre da chamada situação legitimante, que conecta a relação jurídica processual ao direito material. As partes somente serão legitimadas, como já foi dito anteriormente se além de inseridos na dinâmica processual, fizerem parte da relação material de onde surgiu a crise de direito veiculada na demanda.

A situação legitimante é uma mimetização da relação material; ela é construída a partir das afirmações formuladas, na demanda, pelo autor. Logo, ela tem natureza jurídico-

\footnotetext{
$364 \quad$ BEDAQUE. 2006a. p. 278.

365 BEDAQUE. 2006a. p. 279

366 BEDAQUE. 2006a. p. 279. Em complemento, dispõe: "se o autor indicar para figurar como réu no processo pessoa diversa daquela que, segundo a descrição fática por ele mesmo feita, participa da relação substancial, estará configurada a ilegitimidade passiva. Mas, se houver identidade entre o réu e a pessoa que, segundo o autor, deve suportar os efeitos da sentença, por figurar na relação substancial controvertida, ele será parte legítima”. BEDAQUE. 2006a. p. 280.
} 
processual $^{367}$ e não material. É uma imagem artificial criada pelo demandante que serve para, dentre outras coisas, permitir a verificação da presença das condições da ação.

A ideia de situação legitimante é também utilizada por Elio Fazzalari ao tratar da legitimidade. De acordo com o autor essa situação serve de base para que se possa determinar, em concreto, quem pode e deve praticar certo ato no processo ${ }^{368}$. Junto à ideia de situação legitimante, Elio Fazzalari expõe o conceito de situação legitimada como o poder, o dever ou a faculdade que cabe ao sujeito, sendo esse o conteúdo da legitimação ${ }^{369}$. A legitimidade ad causam, em sua doutrina, é observada sob esses dois distintos enfoques.

O que importa para Fazzalari, pois, é a possibilidade de melhor aproveitamento da demanda mediante ingresso de partes legitimadas, ou seja, que dispõem de poderes e deveres para, perante o juiz e todos os demais atores do processo, dizer e contradizer no curso do procedimento ${ }^{370}$, em posição de simétrica paridade ${ }^{371}$. Assim, os sujeitos do processo para além de partes, passam a ser tidos por contraditores, já que o elemento principal do processo para Fazzalari é o contraditório.

Encontrar as partes legítimas é, portanto, descobrir quem são os participantes do contraditório, com poderes e deveres conferidos pela situação legitimante, que, como já

\footnotetext{
$367 \quad$ BEDAQUE. 2006a. p. 281

368 "Chiamiamo situazione legittimante il punto di aggancio della legitimazione ad agire, fuor di metafora la situazione in base alla quale si determina qual'è il soggetto che, in concreto, può e deve compiere un certo atto [...]". FAZZALARI. 1996. pp. 305-6.

369 " $[. .$.$] e situazione legittimata il potere, o la facoltà, o il dovere - o una serie dei medesimi -$ che, di conseguenza, viene a spettare al soggetto individuato, val dire il contenuto della legittimazione, ciò in cui essa consiste". FAZZALARI. 1996. pp. 305-6.

370 "Poiché il provvedimento de quo (quando fosse per essere emanato) o, meglio, i suoi effeti inciderebbero nel patrimônio di taluni soggetti [...] e poiché è ovvia l'esigenza che costoro, in quanto siano per divenire destinatari dell'efficacia del provvedimento giurisdizionale, partecipino all'iter di formazione del medesimo; per queste ragioni - cioè in quanto siano, in ipotesi, legittimati passivi rispetto al provvedimento richiesto - tali soggetti sono contraddittori, legittimati a 'dire e contradire' nel corso del procedimento: legittimati al processo, insomma. Proprio in virtù di tale partecipazione il procedimento è 'processo'. FAZZALARI. 1996. pp. 306-7.

371 PELLEGRINI, Flaviane de Magalhães Barros. O processo, a jurisdição e a ação sob a ótica de Elio Fazzalari. Disponível

https://www.google.com.br/url?sa=t\&rct=j\&q=\&esrc=s\&source=web\&cd=3\&cad=rja\&ved=0CEUQFjAC\& url=http\%3A\%2F\%2Fwww.fmd.pucminas.br\%2FVirtuajus\%2FAno2_08_2003_arquivos\%2FDocente\%2FO $\% 2520$ PROCESSO $\% 2 \mathrm{C} \% 2520 \mathrm{~A} \% 2520 \mathrm{JURISDI} \% 25 \mathrm{C} 7 \% 25 \mathrm{C} 3 \mathrm{O} \% 2520 \mathrm{E} \% 2520 \mathrm{~A} \% 2520 \mathrm{~A} \% 25 \mathrm{C} 7 \% 25 \mathrm{C} 3$ O\%2520SOB\%2520A\%2520\%25D3TICA\%2520DE\%2520ELIO\%2520FAZZALARI.doc\&ei=YjNnUuTo Hsj02wXd94HQBw\&usg=AFQjCNEUwNc9BrQsz2upDkFsKsZL6Jp4_g\&sig2=HCoB0IY77WMaxmEHsA rsSg.
} 
dito, são aqueles que "serão afetados pelo ato final [...] os sujeitos destinatários do provimento" 372 .

\subsection{LITISCONSÓRCIO}

O contraditório pode ser composto por somente dois sujeitos parciais, cada qual ocupante de um dos polos da relação jurídica processual ou por muitos outros, que podem se aglomerar de forma obrigatória ou facultativa em um ou nos dois lados dessa relação. A pluralidade de partes no processo corresponde à situação verificada na relação jurídica material à qual mais de dois indivíduos estão ligados.

A ligação com a relação jurídica substancial os torna partes principais do processo, sem relação de dependência ou acessoriedade, sendo entre si chamados de litisconsortes. Seu ingresso no processo pode ocorrer de maneira originária (quando propõem a demanda ou quando uma demanda lhes é proposta) ou ulterior (quando o juiz lhe determina a citação porque indispensável à relação processual ou por chamamento do réu), ampliando seu aspecto subjetivo, tornando-o mais complexo, sem que, com isso, o multiplique. A relação jurídica processual permanece una ${ }^{373}$.

A resolução da controvérsia com a presença todos os atores envolvidos tem por objetivo evitar a emissão de comandos decisórios contraditórios, guardando a coerência necessária aos provimentos jurisdicionais ${ }^{374}$. Não é possível afirmar, porém, que todo processo que admita instauração de litisconsórcio proporcione essa segurança, já que sua formação não é sempre obrigatória. As situações que admitem formação de litisconsórcio são:

\footnotetext{
Art. 46. Duas ou mais pessoas podem litigar, no mesmo processo, em conjunto, ativa ou passivamente, quando:

I - entre elas houver comunhão de direitos ou de obrigações relativamente à lide;

II - os direitos ou as obrigações derivarem do mesmo fundamento de fato ou de direito;

III - entre as causas houver conexão pelo objeto ou pela causa de pedir;

IV - ocorrer afinidade de questões por um ponto comum de fato ou de direito.
}

\footnotetext{
$372 \quad$ PELLEGRINI. Obra citada.

373 DINAMARCO. 2006b. p. 341.

374 "A admissibilidade da conglomeração de dois ou mais sujeitos como demandantes ou como demandados tem por fundamento a existência de situações da vida envolvendo mais de duas pessoas e não só duas; e por objetivo, favorecer a harmonia de julgados e a economia processual”. DINAMARCO. 2006b. p. 341.
} 
Para Cândido Rangel Dinamarco, a conexidade existente entre relações processuais é responsável por autorizar a formação do litisconsórcio - “conceituada ela como a relação de semelhança entre duas ou várias demandas que tenham um ou mais elementos

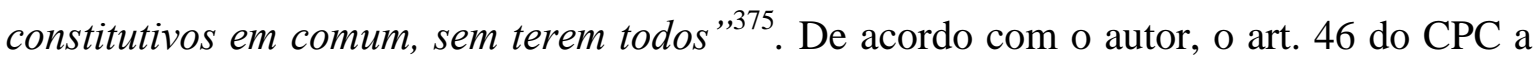
tem como fundamento de seus quatro incisos, definidores das hipóteses de cabimento do litisconsórcio, que vão desde a ligação mais forte entre as causas (art. 46, I do CPC comunhão) até a mais tênue (art. 46, IV do CPC - mera afinidade) ${ }^{376}$. Dentre todas, parece, a partir da doutrina de Cândido Rangel Dinamarco, que a hipótese do inciso I do art 46 do CPC seja a que mais se aproxima ao objeto deste estudo.

\begin{abstract}
comunhão em direitos e obrigações (art. 46, inc. I) "[...] é uma espécie potenciada e particularmente intensa de conexidade entre demandas. Comunhão, nesse emprego, é cotitularidade. Ocorre quando duas ou mais pessoas se apresentam como titulares de um só direito ou quando elas sejam apontadas como obrigadas por um vínculo só. Exemplos eloquentes são a solidariedade ativa e a passiva, fenômenos pelos quais todos os credores ou devedores participam de uma só e única relação, in solidum (CC, art. 264) - cada um deles é legitimado a propor a demanda isoladamente ou a figurar como réu único (arts. 898 e 904), mas a lei processual admite que se litisconsorciem, segundo a vontade de quem propõe a demanda inicial (litisconsórcio ativo ou passivo, conforme o caso - CPC, art. 46, inc. I). [...] dessa locução se infere que o inc. I do art. 46 só se aplica quando estiver posta em juízo a própria relação jurídico-material onde dois ou vários figuram como credores ou como devedores. Não dá azo a esse litisconsórcio a junção de duas pretensões autônomas, ainda quando apoiadas na mesma relação jurídica fundamental. É indispensável que os próprios direitos ou obrigações com mais de um titular estejam postos na demanda para serem objeto de cognição principaliter, não incidenter tantum ${ }^{377}$.
\end{abstract}

Como reforço argumentativo, destaca-se que todo litisconsorte tem legitimidade ad causam; afinal, ambos os conceitos decorrem da ligação havida pela parte com a relação jurídica substancial. Logo, precede à admissibilidade do litisconsórcio a verificação da possibilidade de cada um dos sujeitos integrarem, por si só, uma demanda que verse sobre o mesmo objeto ${ }^{378}$.

Como dito anteriormente, o litisconsórcio pode ser formado na primeira manifestação das partes no processo (quando é chamado de originário) ou em momento posterior (sendo conhecido por ulterior). Sua redução ou extinção podem ocorrer no curso do processo, sem

\footnotetext{
$375 \quad$ DINAMARCO. 2006b. p. 342.

376 DINAMARCO. 2006b. p. 342.

377 DINAMARCO. 2006b. p.. 345-6.

378 "Essa regra aplica-se a qualquer espécie de litisconsórcio, seja ele facultativo ou necessário, unitário ou comum, ativo ou passivo, inicial ou ulterior”. DINAMARCO. $2006 \mathrm{~b}$. p, 347.
} 
que importem no encerramento deste ${ }^{379}$. A unicidade do processo litisconsorcial, com partes independentes, proporciona uma relativa autonomia a cada um dos atores do processo.

A autonomia não pode ser tida por absoluta, pois o Código de Processo Civil prevê diversas hipóteses de comunicação entre as partes mediante a prática de atos por qualquer delas. Exclui-se a possibilidade de uma das partes prejudicar as demais que ocupem o mesmo polo da demanda pela prática de um ato processual; no entanto, todas podem vir a se beneficiar do ato de qualquer dos litisconsortes, a exemplo do previsto nos artigos 320, I e 509 caput e parágrafo único do CPC.

Igualmente, na formação do litisconsórcio unitário - quando o tratamento dispensado aos litisconsortes deve ser uniforme, assim como o provimento final - o ato que possa beneficiar aos demais litisconsortes tem o condão de estender seus efeitos a todos aqueles que ocupem o mesmo polo do responsável por sua prática.

Definir uma figura litisconsorcial é pressupor que exista alguma outra, que não exija um tratamento uniforme a todos os integrantes do litisconsórcio. E, de fato, a legislação processual reconhece, como visto no art. 46 do CPC, diversas formas de ligação entre os possíveis atores processuais, que de acordo com a intensidade da relação estabelecida, exige um tratamento processual adequado.

\subsubsection{Litisconsórcio unitário ou comum}

O litisconsórcio unitário, nas palavras de Cândido Rangel Dinamarco, "se caracteriza pela homogeneidade dos tratamentos atribuídos aos litisconsortes, para que o julgamento final seja homogêneo para todos" ${ }^{380}$. Essa necessidade de padronização decorre da incindibilidade da relação jurídica material à qual estão vinculados os litisconsortes, que força a existência de uma única decisão judicial como forma de evitar a edição de provimentos judiciais contraditórios.

\footnotetext{
379 "Em nenhuma das hipóteses é correto falar em extinção do processo, ainda que parcial - porque o processo litisconsorcial é uno e não existem tantos processos quantos forem os litisconsortes. A relação processual, que antes tinha mais sujeitos em um de seus polos, agora passa simplesmente a ter menos - sendo decisão interlocutória e não sentença a decisão que exclui um ou alguns dos litisconsortes". DINAMARCO. 2006b. p. 352.

380 DINAMARCO. 2006b. p. 355.
} 
Quando o processo é conduzido por colegitimados extraordinários que atuam em prol de um único substituído, igualmente, o litisconsórcio verificado será unitário, por impossibilidade de fracionamento do objeto do processo ${ }^{381}$. A unitariedade, portanto, está relacionada ao regime de tratamento dos litisconsortes ${ }^{382}$.

Por outro lado, quando os litisconsortes integrarem relações jurídicas distintas, que puderem ser resolvidas por provimentos judiciais distintos que, embora contraditórios, não colidam entre $\mathrm{si}^{383}$, eles poderão receber tratamento processual distinto, na forma do art. 48 do CPC. Esse litisconsórcio será comum, ou seja, caracterizado somente pela reunião de duas ou mais pessoas em um mesmo polo processual.

A distinção entre as duas figuras está fundada na possibilidade de execução de decisões contraditórias.

\subsubsection{Litisconsórcio necessário e facultativo}

Apesar da relativa facilidade de divisão entre as modalidades de litisconsórcio, algumas confusões conceituais são feitas pelo próprio CPC. Ao tentar definir o unitário, a legislação processual acabou por confundi-lo com as situações em que a formação do litisconsórcio é obrigatória - o litisconsórcio necessário. No art. 47 do CPC, as definições se misturam, denotando nítida confusão do legislador em relação às razões fundantes de cada uma das figuras litisconsorciais.

Se a divisão realizada entre o litisconsórcio unitário e o comum encontra sustentação no tratamento dispensado aos litisconsortes, a obrigatoriedade de sua formação responde pelas categorias necessário e facultativo ${ }^{384}$. A identificação da necessidade do litisconsórcio não é fornecida pelos incisos do art. 46 do CPC e sim pelo caput do art. 47, cuja redação é

\footnotetext{
$381 \quad$ DINAMARCO. 2006b.. p. 359.

382 DINAMARCO. 2006b.. p. 359.

383 "O eixo de referência é sempre representado pela viabilidade prática da efetivação das decisões divergentes (Barbosa Moreira) e, nesses casos, o litisconsórcio é comum e não unitário". DINAMARCO. 2006b.. p. 357.

384 DINAMARCO. 2006b.. p. 359.
} 
criticada pela doutrina ${ }^{385}$. Do que se pode apreender, o litisconsórcio será sempre necessário quando for unitário e nos casos em que a lei assim dispuser ${ }^{386}$.

Nem todo litisconsórcio unitário é necessário, embora a intenção seja a de evitar a existência de mais de um provimento judicial sobre a mesma relação jurídica substancial, para que sejam diminuídas as chances de conflito entre as decisões. Apesar da redação do art. 47 do CPC, existem situações em que o litisconsórcio unitário seja facultativo, a exemplo das hipóteses de legitimação extraordinária concorrente ${ }^{387}$.

Não apenas o litisconsórcio unitário é capaz de impor a necessidade de sua formação. Há casos em que a lei pode determinar a obrigatoriedade de formação do litisconsórcio mesmo quando as partes sejam integrantes de relações autônomas ${ }^{388}$, conforme disposto no art. 47 do CPC.

Para a dinâmica do processo civil brasileiro, quando estivermos diante de um litisconsórcio necessário, ele poderá ser formado pela iniciativa de qualquer das partes, inclusive do juiz (art. 47, parágrafo único do CPC); ao contrário, quando o litisconsórcio for facultativo, somente o autor poderá decidir sobre a formação de um processo litisconsorcial ${ }^{389}$.

De acordo com os pedidos formulados pelo requerente, é possível, ainda, classificar o litisconsórcio em alternativo ou eventual, ocorrendo aquele quando ficar demonstrada a dúvida sobre o verdadeiro legitimado passivo (não importa ao autor quem deve adimplir, apenas é de seu desconhecimento quem seja o verdadeiro responsável pelo adimplemento) e este quando há manifestação de preferência por um dos requeridos, assumindo os demais posição subsidiária.

\footnotetext{
385 Para Dinamarco, II, p. 360, a redação é confusa e precisa ser decifrada.

386 "O litisconsórcio só será necessário (a) quando a causa versar um objeto incindível, conforme disposição genérica contida no art. 47 do Código de Processo Civil ou (b) quando a lei assim o estabelecer de modo específico, embora o objeto não seja incindível”. DINAMARCO. 2006b.. p. 361.

387 "A lei não exige que atuem em conjunto, o que significa que não é necessário o litisconsórcio entre eles: só proporão a demanda em conjunto se assim preferirem. Mas é absolutamente único o objeto da demanda de cada um deles, sendo um só o substituído [...]”. DINAMARCO. 2006b.. p. 366. Ainda de acordo com Dinamarco, "há também casos de litisconsórcio unitário facultativo entre legitimados ordinários, o que sucede sempre que de algum modo a lei autorize a demanda individual (facultatividade) mas o objeto da demanda seja incindível (unitariedade)" DINAMARCO. 2006b.. p. 367.

388 Dentre os mais recorrentes, os determinados no rito da ação popular, da usucapião e dos processos envolvendo atos praticados por cônjuges.
}

389 DINAMARCO. 2006b.. p. 369. 


\subsubsection{Litisconsórcio e o princípio da demanda}

O perfil prático do litisconsórcio facultativo é o que melhor atende ao princípio da demanda, por respeitar a plenitude da liberdade do requerente de ajuizar a ação contra a parte que entender responsável pelo surgimento ou resolução da crise de direito que busca solucionar (legitimado) ${ }^{390}$. A imposição de limites à propositura de ação judicial fere os preceitos defendidos pelos processualistas mais tradicionais, que defendem, sobretudo, a liberdade de o indivíduo não ser obrigado a demandar contra quem não deseja.

Como justificar, então, a existência do litisconsórcio necessário perante os limites rígidos do processo civil? É inegável que a obrigatoriedade de formação do litisconsórcio seja fator limitador do princípio da demanda. O parágrafo único do art. 47 do CPC representa, verdadeiramente, uma derrogação desse princípio ao impedir que o autor tenha plena liberdade de indicar quem deve figurar no polo passivo da demanda - e até mesmo no ativo 391

Nesses casos, é permitido ao juiz deduzir a presença do litisconsórcio de outros dados fornecidos no processo que não apenas as alegações do requerente (como documentos juntados e elementos extraídos da resposta do requerido) ${ }^{392}$. Encontrado argumento que

\footnotetext{
$390 \quad$ "Il principio della domanda fa si che l'oggeto del processo si concentri sotto il profilo soggetivo su quello che l'autore ha ritenuto di dedurre in giudizio, a lui spettando, sulla base dela nozione di legittimazione attiva e passiva in senso processuale, affermare il diritto soggettivo fatto valere come esistente a suo favore ed a carico del soggetto che egli individui come convenuto". FRASCA, Raffaele. Note sui presupposti del litisconsorzio necessario I. In: Rivista di Diritto Processuale. Anno LIX. Seconda Serie. n. 2. Abril-junh, 1999. p. 407.

391 "[...] una volta constatato che la tesi restrittiva stessa (a meno di non vedersi confinata ad un ipotesi per cui la regolamentazione sarebbe fornita dall'art. 101 c.p.c., come poco sopra si è detto) implica che l'istituto dell'art. 102 c.p.c. comporti una deroga al principio della domanda e della libertà di individuazione del convenuto da parte dell'attore, va condivisa l'affermazione dominante in dottrina che la disciplina del litisconsorzio necessario segni un limite alla libertà d'azione espressa dal principio della domanda. FRASCA. 1999. p. 412.

392 "Se, quindi, l'attore nel formulare la domanda individua il soggeto passivo di essa in un certo soggeto e dai documenti allegati o dallo svolgimento processuale o dalle difese del convenuto emerge che la situazione in base alla quale ha agito o quella che faccia capo allo stesso convenuto sia tale da imporre la necessità del litisconsorzio con altri soggeti o dal lato attivo o dal lato passivo del rapporto processuale, il giudice non può che applicare l'art. 102, ancorché la domanda sia stata prospettata dall'attore senza la narrazione di fatti tali da evidenziare la situazione impositiva del litisconsorzio necessario ed addirittura con la deduzione del rapporto come non plurisoggetivo (o dal lato attivo o dal lato passivo)". FRASCA. 1999. p.408.
} 
indique a presença de litisconsórcio necessário, o juiz deve aplicar o parágrafo único do art. 47 do $\mathrm{CPC}^{393}$.

Diante das definições apresentadas, seria possível pensar em alguma técnica disponível ao magistrado brasileiro, que pudesse autorizá-lo a incluir um terceiro (ente federativo) na lide (processo de controle de políticas públicas), conferindo-lhe, a partir de então, a qualidade de parte $^{394}$ ?

\subsection{INTERVENÇÃO DE TERCEIROS}

O Código de Processo Civil dispõe de algumas técnicas que autorizam a inclusão de um terceiro em um processo existente, já e ainda $a^{395}$. O terceiro pode ingressar no processo em ambos os polos, a depender de sua relação com o objeto da lide. Intervenção litisconsorcial, chamamento ao processo, nomeação à autoria, oposição, denunciação da lide e assistência são, basicamente, as formas utilizadas para inclusão de um terceiro em um processo pendente entre outras pessoas - as partes $^{396}$.

A aplicação do parágrafo único do art. 47 do CPC pelo juiz não é uma forma de intervenção de terceiros, uma vez que o litisconsorte necessário deve ser considerado parte originária, não citada para a ação por falta do autor.

393 "Quando il litisconsorzio è necessário...rispetto ala proposizione dela domanda, l'atorre che agisce da solo o contro uno solo si espone al rigetto della domanda. Manca infatti la condizione dell'azione che abbiamo chiamato legitimatio ad causam. Non si tratta di un semplice difetto del processo che si possa riparare per via; ma di un difetto dell'azione, la quale intanto appartiene a chi agisce o contro il suo convenuto, in quanto la stessa azione appartiene ad altri o contro altri, e quindi non appartiene a chi agisce da solo o contro uno solo". ". CHIOVENDA, Giuseppe. Principii di diritto processuale civile. Napole: Jovene, 1965. p. 1083-1084

394 "En franchissant un degré de plus dans la qualification de partie, il est possible d'observer l'existence de tiers intéressés à la procédure, sans que leur association à l'instance les y intègre en qualité de partie, avec l'emsemble des prérogatives et des charges processuelles attachées à cette qualité. [...]". CADIET. 2010. p. 723.

$395 \quad$ shon und noch, como lembra DINAMARCO. 2009b. p. 379.

396 "Plus radicalement encore, les tiers, initialement étrangers à l'instance, en tout ou en partie, peuvent y devenir parties. Les mécanismes sont nombreux qui permettent cette mutation. Ce changement de qualité peut être l'effet, passif, d'une transmission de l'action, par exemple, en cas de décès d'une partie ou de cession de créance. Ce peut être également le resulta d'une iniciative procédurale des tiers (intervention volontaire, exercise d'um recours, voire action enn référé), des parties (intervention forcée des tiers), voire du juge lui-même (mise em cause des tiers em matière civile, mise em examen em matière pénale)". CADIET. 2010. p. 725. 
A justificativa para promoção das figuras interventivas, segundo Cândido Rangel Dinamarco, derivam da possibilidade de projeção de algum efeito indireto sobre a esfera de direitos do terceiro ${ }^{397}$. Como o $\mathrm{CPC}$ restringe às partes do processo a extensão da autoridade da coisa julgada (art. 472), por vezes as partes ou o próprio terceiro têm interesse em incluí-lo na relação jurídica processual iniciada sem sua presença. Embora grande parte da doutrina processualista encontre razões procedimentais para justificar o ingresso do terceiro em lide pendente, a verdade é que o interesse deriva dos escopos do processo, como destaca Sérgio Bermudes ${ }^{398}$ :

\begin{abstract}
Os conflitos sociais não se exaurem na divergência entre os titulares da pretensão e da resistência, que se confrontam. Acabam, de algum modo, enredando terceiras pessoas que, não sendo contendores, são atingidas pela lide. Por isso mesmo, a prestação jurisdicional, muitas vezes, extravasa do universo dos vínculos exclusivos entre o autor e o réu e apanha outras pessoas. $\mathrm{O}$ direito admite, em consequência, que essas pessoas ingressem, voluntariamente, na relação processual, ou sejam convocadas a integrá-las, ou porque sofrerão, inevitavelmente, as consequências do que nela se decidir, ou porque a prevenção, ou a solução da lide só terá plena utilidade e eficácia, se se estender a elas a prestação jurisdicional.
\end{abstract}

Dentre as modalidades interventivas listadas pelo CPC, nenhuma serve ao objetivo desse estudo, que é permitir a inclusão de um dos entes federativos, em um processo que tenha por a omissão da Administração Pública em realizar determinada política social, cuja competência para execução direta seja atribuída, por lei, a esse ente, que por opção do requerente não foi indicado para ocupar o polo passivo da demanda.

\title{
3.6.1. Intervenções voluntárias e provocadas
}

As técnicas de inclusão de terceiro em um processo judicial podem ser divididas em voluntárias (quando o próprio terceiro opta por ingressar na demanda) e provocadas (quando uma das partes intenta incluir o terceiro na lide).

\subsubsection{Intervenções voluntárias}

Dentre as modalidades voluntárias estão a intervenção litisconsorcial, a oposição e a assistência.

\footnotetext{
$397 \quad$ DINAMARCO. 2009b. p.. 377.

398 BERMUDES, Sérgio. Introdução ao processo civil. Rio de Janeiro: Forense, 1995. pp. 80-1.
} 
A intervenção litisconsorcial voluntária ocorre com a apresentação, pelo terceiro, de demanda conexa à do autor, em face do mesmo réu, com pedido idêntico de tutela jurisdicional. Embora a tutela pretendida seja de mesma natureza, há uma nítida ampliação do objeto da demanda, já que o terceiro apresenta pedido mediato próprio. Portanto, há dois elementos que demonstram a inutilidade dessa modalidade interventiva para o objetivo da pesquisa: (i) o ingresso do terceiro ocorre no polo ativo da demanda; (ii) há ampliação objetiva da demanda.

Quanto à oposição, ela está prevista no art. 56 do CPC como uma demanda autônoma porém incidental a outra pendente - e tem por finalidade apresentar ao juízo pedido de tutela sobre o mesmo bem objeto de disputa entre as partes da ação originária. Então, existem duas relações jurídicas processuais, sendo a primeira aquela havida entre autor e réu originários e, a segunda, que envolve o terceiro, agora opoente, e as partes da demanda originária, jungidos em litisconsórcio passivo necessário. Não há ampliação objetiva da demanda, porém, sua função é permitir todas as partes busquem obter ou tutelar o mesmo bem. Há uma disputa de titularidade que envolve as partes do processo - o que não ocorre no processo de controle de políticas públicas.

Já a assistência, prevista no art. 50 do CPC, é caracterizada por uma ajuda que o terceiro presta a uma das partes. Obviamente, não se trata de ação filantrópica; esse auxílio pressupõe o interesse do terceiro sobre a resolução da lide em favor da parte que o recebe. Não há adição de pedidos, seja por tutela jurisdicional ou por outro bem pretendido pelo terceiro $^{399}$, bastando em si o auxílio prestado a uma das partes ${ }^{400}$, que mantêm sua posição original no processo, enquanto o terceiro adquire a condição de assistente simples (art. 52 do CPC) ou litisconsorcial ${ }^{401}$ (art. 54 do CPC).

\footnotetext{
$399 \quad$ "A intervenção do terceiro na qualidade de assistente não altera o objeto do processo, uma vez que ele se limita a aderir à pretensão do assistido, sem formular demanda nova. Daí, chamar-se intervenção adesiva em outros ordenamentos jurídicos (intervento adesivo, Nebenintervention)". DINAMARCO. 2009b. pp. 396-7

$400 \quad$ "O assistente insere-se na relação processual com a finalidade ostensiva de coadjuvar a uma das partes, de ajudar ao assistido, pois o assistente tem interesse em que a sentença venha a ser favorável ao litigante a quem assiste". CARNEIRO, Athos Gusmão. Intervenção de Terceiros. São Paulo: Saraiva, 2006. pp. $177-8$

401 "A má redação de dispositivos do Código de Processo Civil dá a entender que o assistente litisconsorcial não seja um assistente e sim um litisconsorte, mas essa ideia é inteiramente falsa. A locução considera-se litisconsorte, contida no art. 54, significa somente que as possibilidades de atuação desse assistente serão tantas quantas as de uma parte principal, ou seja, tantas quanto a de um litisconsorte. [...] O
} 
Não sendo possível o assistente assumir a posição de parte para todos os fins, especialmente para adimplir a obrigação porventura imposta pela decisão judicial, igualmente o instituto não tem utilidade para os fins pretendidos nesse estudo.

Dentre as três modalidades interventivas expostas, o traço comum existente, a voluntariedade, por si só as afasta da estrutura aqui pensada. Como dito anteriormente, o processo deve servir para resolução de crises de direito surgidas no cotidiano dos indivíduos, mediante a instauração de uma relação jurídica processual conduzida com obediência ao contraditório e, como todo ato estatal, deve obedecer aos princípios da eficiência e economia.

Pois bem. Caso os entes federados assumissem voluntariamente seus papéis, cumprindo com as responsabilidades que lhes são atribuídas por lei (ou, pelo menos, aceitando responder por suas supostas omissões perante o Judiciário) toda essa discussão seria inócua. A grande motivação dessa tese é justamente a resistência: (i) dos entes responsáveis pelas políticas públicas questionadas judicialmente em assumir suas posições processuais e; (ii) do Judiciário em aceitar o pedido do ente originariamente incluído no polo passivo da demanda, para autorizar o ingresso de outro, considerado responsável pela execução direta da política questionada.

\subsubsection{Intervenções provocadas}

As técnicas de inclusão forçada de um terceiro em um processo judicial, que estão previstas no Código de Processo Civil, são a nomeação à autoria, a denunciação da lide e o chamamento ao processo.

Disposta nos artigos 62 e 63 do CPC, a nomeação à autoria serve ao detentor ou àquele que provoca dano ao bem de outrem por ordem, ou em cumprimento de instruções de terceiro. Somente pela definição das hipóteses de cabimento já é possível descartar a utilidade desta técnica para os fins desejados.

assistente litisconsorcial, tanto quanto o simples, não traz ao processo demanda alguma a ser julgada, nem em face dele foi proposta qualquer demanda a ser julgada na sentença de mérito. A procedência da demanda inicial não lhe atribuirá bem algum nem ele sofrerá uma condenação”. DINAMARCO. 2009b. p. 400. 
Já o art. 70 do CPC prevê que a denunciação de lide como técnica útil: I - ao alienante, na ação em que terceiro reivindica a coisa, cujo domínio foi transferido à parte, a fim de que esta possa exercer o direito que da evicção Ihe resulta; II - ao proprietário ou ao possuidor indireto quando, por força de obrigação ou direito, em casos como o do usufrutuário, do credor pignoratício, do locatário, o réu, citado em nome próprio, exerça a posse direta da coisa demandada; III - àquele que estiver obrigado, pela lei ou pelo contrato, a indenizar, em ação regressiva, o prejuízo do que perder a demanda.

Igualmente, da simples exposição das hipóteses que autorizam a utilização da denunciação da lide, é possível afastá-la como técnica adequada.

Por fim, o chamamento ao processo, previsto no art. 77 do CPC, admite que o réu de uma demanda possa incluir, como litisconsorte passivo, os demais devedores solidários da obrigação cobrada. A princípio, a técnica apresentada por esse artigo seria útil para inclusão de um ente federado em um processo de controle de políticas públicas - em relação à qual seria responsável pela execução - que, por opção do requerente, não foi incluído no polo passivo da demanda.

No entanto, o chamamento ao processo é técnica processual admitida somente para lides que envolvam inadimplemento de obrigações de pagar, o que não envolve (diretamente) o problema inerente às políticas públicas sociais. Os pedidos formulados nos processos de controle dessas políticas envolvem sempre obrigações de fazer ou dar (entregar).

Esgotadas as técnicas previstas pelo Código de Processo Civil, vê-se que os mecanismos colocados à disposição do Judiciário não favorecem sua participação nem mesmo no processo de interesse público. $\mathrm{O}$ ordenamento processual ainda dispõe de grande bloqueio em relação a interferências no princípio da demanda. A inclusão de terceiro no processo, decorrente de um juízo de conveniência do magistrado não é expressamente autorizada pelo ordenamento jurídico brasileiro, ao contrário do que se passa nos ordenamentos italiano e francês. Porém, Cândido Rangel Dinamarco destaca que “às vezes o juiz brasileiro vai além e determina a citação de novo réu fora dos casos de litisconsórcio 
necessário; e os tribunais entendem que a situação se regulariza e o processo prossegue com todos, se houver concordância geral" ${ }^{\prime 402}$.

Importa dizer que, sempre que o magistrado se deparar com um processo de controle de políticas públicas movido em face de um ente que não tenha responsabilidade direta pela execução da política questionada, nada poderá fazer em relação à incorreta indicação do polo passivo da demanda, sendo a extinção do processo sem resolução do mérito por carência de ação (ilegitimidade) a única alternativa disponível no $\mathrm{CPC}^{403}$.

\subsection{INTERVENÇÃO IUSSU IUDICIS}

Porém, a extinção desses processos sem resolução do mérito, por carência de ação, geraria desatendimento de diretos sociais caros à construção do Estado Democrático de Direito tais como saúde e educação - e, por essa razão, o juiz deveria ser autorizado, pelos mandamentos de otimização constitucionais, a determinar a citação do ente responsável pela execução direta da política pública questionada, ainda que não tenha sido indicado pelo autor da ação para figurar no polo passivo da demanda.

A intervenção iussu iudicis é frequentemente criticada em virtude da ampliação excessiva dos poderes conferidos ao Magistrado. É que, historicamente, os dispositivos que a previram no ordenamento italiano sempre relegaram ao convencimento do Juiz ${ }^{404}$ a possibilidade de incluir novos atores em um processo judicial.

A proposta que se pretende apresentar foge do padrão discricionário do instituto, fixando como causa e limite da atuação ex officio do Juiz ${ }^{405}$ o atendimento de direitos sociais nos

\footnotetext{
$402 \quad$ DINAMARCO. 2009b. p. 351

$403 \quad$ "O la domanda non può proporsi contro quel convenuto da solo che fu chiamato in causa o dal solo attore, e in questo caso si trata di um diffeto di legitimatio ad causam che dá luogo a rigetto della domanda; o può proporsi, e in tal caso il giudice non può in alcuno modo pretendere che sia proposta anche in confronto dei litisconsorti”. CHIOVENDA. 1965. p. 730.

$404 \quad$ Art. 107. (Intervento per ordine del giudice). Il giudice, quando ritiene opportuno che il processo si svolga in confronto di un terzo al quale la causa e' comune, ne ordina l'intervento.

Art. 270. (Chiamata di un terzo per ordine del giudice). La chiamata di un terzo nel processo a norma dell'articolo 107 può essere ordinata in ogni momento dal giudice istruttore per una udienza che all'uopo egli fissa.

Se nessuna delle parti provvede alla citazione del terzo, il giudice istruttore dispone con ordinanza non impugnabile la cancellazione della causa dal ruolo.

405 "Hoje acentua-se a ligação entre processo e Constituição no estudo concreto dos institutos processuais, não mais colhidos na esfera fechada do processo, mas no sistema unitário do ordenamento
} 
processo de controle judicial de políticas públicas ${ }^{406}$. A ideia não confere ao magistrado margem discricionária para integração da lide, mas sim uma ordem decorrente da própria divisão de competências estabelecida por lei.

O argumento que, hoje, autoriza o ajuizamento de ação em face de qualquer um dos entes é o mesmo que suporta a chamada do terceiro por ordem do juiz, qual seja, a inafastável efetividade dos direitos sociais. Se as normas processuais não podem servir de empecilho à satisfação desses direitos, elas podem ser úteis, ao menos, para otimizar as políticas públicas sociais. O que os tribunais têm feito ultimamente, porém, é impor um sacrifício desmedido às estruturas da Administração Pública em prol da satisfação dos direitos sociais, sem ver que é possível atingir o mesmo objetivo com obediência aos princípios da eficiência e economicidade.

A discussão sobre o princípio da demanda, nesse ponto, é nítido resquício de resistência infundada à alteração do standard processual além de paradoxo ideológico, por representar uma barreira processual à efetivação de direitos fundamentais. Os processos que veiculam pedidos de controle de políticas públicas não têm, e nem devem ter, pretensão motivada por alguém; não se trata de insatisfação pontual em relação a este ou aquele ente, sendo motivada pelo inadimplemento voluntário de uma política social por parte do governo.

Portanto, a determinação de modificação do polo passivo desse tipo de demanda não importa em obrigar alguém a litigar contra quem não queira, não há pessoalidade nesse tipo de pleito. Acostumado a lidar com interesses inerentes ao direito privado ${ }^{407}$, em que os

jurídico: é esse o caminho, foi dito com muita autoridade, que transformará o processo, de simples instrumento de justiça, em garantia de liberdade”. GRINOVER, Ada Pellegrini; DINAMARCO, Cândido Rangel; CINTRA, Antônio Carlos de Araújo. Obra citada. p. 72.

$406 \quad$ "Isso significa, em última análise, que o processo não é apenas instrumento técnico, mas sobretudo ético. E significa, ainda, que é profundamente influenciado por fatores históricos, sociológicos e políticos. Claro é que a história, a sociologia e a política hão de parar às portas da experiência processual, entendida como fenômeno jurídico. Mas, é justamente a Constituição, como resultante do equilíbrio das forças políticas existentes na sociedade em dado momento histórico, que se constitui no instrumento jurídico de que deve utilizar-se o processualista para o completo entendimento do fenômeno processo e de seus princípios". GRINOVER, Ada Pellegrini; DINAMARCO, Cândido Rangel; CINTRA, Antônio Carlos de Araújo. Obra citada. p. 73.

407 "De um lado, tem-se a clássica concepção de que, por tratar o processo civil predominantemente de interesses privados, é razoável que se dê às partes a prioridade na escolha do momento em que a proteção ao interesse deve ser realizada, bem como a determinação do litígio que será examinado pelo Poder Judiciário. Afinal, se os interesses privados são, em princípio, disponíveis, disponível também deve ser a sua forma de proteção [...] Por outras palavras, o princípio da demanda, aplicável de regra ao processo civil, decorre naturalmente da essência dos direitos subjetivos sujeitos à atuação jurisdicional civil: tratando-se de direito disponível, fica a atuação estatal condicionada ao pedido formulado pela parte. E, se esta condição impõe-se 
indivíduos devem ter protegidos seus direitos de liberdade, o processo civil tende a repudiar qualquer manifestação que possa violar essa premissa. No entanto, o processo que veicula interesse público, mormente os rumos de uma política pública social, não pode ser encarado como um direito posto ao livre exercício pelos indivíduos.

Não se afirma que o indivíduo não possa pleitear um direito subjetivo por meio de uma ação meramente individual ${ }^{408}$; a crítica é dirigida ao caráter privado que se tem dado a demandas judiciais de perfil nitidamente público ${ }^{409}$. Como proposta, é apresentada a possibilidade de intervenção do juiz para correção do polo passivo da demanda, ainda que não esteja configurado o litisconsórcio necessário ou não seja admissível nenhuma das modalidades interventivas previstas no CPC.

De lege ferenda, em nome do princípio da adequação, sugere-se a inclusão da medida no Anteprojeto de Controle de Políticas Públicas elaborado pelo CEBEPEJ; de lege lata, sugere-se a aplicação imediata da medida, com apoio no princípio da adaptabilidade e por obediência à necessidade de efetivação dos direitos sociais e aos princípios da economia e da efetividade.

"Porque vai mal nosso sistema de saúde, e qual o remédio para curá-lo é a grande questão que se coloca. Questão esta cuja resposta muito provavelmente não será dada pela medicina, mas sim pelo Direito Financeiro e pela Administração Pública" ${ }^{410}$. Essa afirmação de José Maurício Conti demonstra que a natureza dos problemas para efetivação dos direitos sociais está intimamente ligada ao direito material. Porém, não esquece que o processo tem servido de elemento catalisador para o aumento da crise no setor da saúde, ao dizer que a organização das finanças pelos entes federados tem sido agravada pela forte

como dever ao juiz, logicamente a atividade jurisdicional estará também limitada àquilo que fora pedido pela parte". ARENHART. Obra citada. p. 2.

$408 \quad$ Conforme salientado por GRINOVER, Ada Pellegrini. A coisa julgada no litisconsórcio facultativo unitário... "Claro que não pode furtar-se a dar respostas às pretensões individuais, baseadas em direitos subjetivos, veiculadas por ações meramente individuais. Mas, nesse caso, deve ter bem presente os efeitos que sua decisão acarretará para a política pública de saúde [...]”

"A natureza instrumental do direito processual impõe sejam seus institutos concebidos em conformidade com as necessidades do direito substancial. Isto é, a eficácia do sistema processual será medida em função de sua utilidade para o ordenamento jurídico material e para a pacificação social". BEDAQUE, José Roberto dos Santos. Direito e Processo. Influência do direito material sobre o processo. 4. ed. São Paulo: Malheiros. 2006b. p. 17.

410 CONTI, José Maurício. Saúde não precisa só de dinheiro, mas de boa gestão. http://www.conjur.com.br/2013-out-22/contas-vista-saude-nao-dinheiro-boa-gestao 
interferência do Poder Judiciário, "exigindo esforço redobrado dos gestores para realocar recursos orçamentários, alterando a programação financeira dos entes federados" 411.

Como já dito anteriormente, não se defendem aqui teorias de reforço à reserva do possível ou outros argumentos restritivos que impeçam ou obstaculizem a efetivação de direitos sociais. Pelo contrário, o que se busca é racionalizar o procedimento como forma de potencializar a execução de políticas públicas e seus espaços de controle - afinal, é difícil fiscalizar o gasto de dinheiro quando ele é feito de forma difusa, randômica e sem critérios.

Tomado o exemplo da saúde, se a compreensão acerca das responsabilidades atribuídas pela Lei 8080/90 pelos cidadãos for dificultada pela especificidade dos termos utilizados e conhecimentos necessários, não importa dizer que o juízo não possa fazer, em confronto entre os entes presentes na lide, a delimitação de suas responsabilidades.

Nesses casos, em que possa haver dúvidas - e quando haja urgência -, poderia ser estabelecido um procedimento semelhante ao previsto no ordenamento para consignação em pagamento decorrente de dúvida acerca da titularidade do crédito (art. 898, última parte, do CPC). Primeiro, seria determinado o cumprimento imediato da execução da política pública objeto da demanda; em um segundo momento, depois de satisfeito o pedido formulado pelo requerente, o processo continuaria a correr somente entre os entes federados.

A questão, portanto, não passa por uma faculdade do magistrado, mas sim pelo destino a ser dado ao processo de controle de políticas públicas. Em vez de aplicar a norma processual que determina a extinção do processo, o juiz, em respeito à importância do direito debatido em juízo, determina que outro ente federativo integre a lide que pode servir, inclusive, para solucionar dúvida porventura existente acerca da responsabilidade pela execução de determinada política pública. É a influência do direito material sobre o princípio da demanda que confere ao juiz mais poderes, quando o interesse público incidir sobre o objeto da demanda.

411 CONTI, José Maurício. Saúde não precisa só de dinheiro, mas de boa gestão. http://www.conjur.com.br/2013-out-22/contas-vista-saude-nao-dinheiro-boa-gestao 
O Magistrado, de resto, permanece autorizado, como já o é nos casos em que exista litisconsórcio, a controlar a presença das partes do processo, podendo exclui-las ou mantêlas da relação jurídica processual.

A adoção de medidas pelo Juiz nesse caso não seria, propriamente, inovação no ordenamento jurídico brasileiro. O Código Minerário vigente (DL 227/67), em seu art. 27, VI e seguintes dispõe sobre o procedimento judicial de apuração dos valores devidos ao proprietário de bem imóvel submetido a atividades de pesquisa.

Pelo que se observa, a inércia do Judiciário é quebrada somente pelo encaminhamento de ofício pelo DNPM, que sequer participa da relação jurídica processual, desenvolvida entre o detentor do Alvará de Pesquisa, o proprietário do bem imóvel e o Ministério Público, na condição de representante do interesse da União. Veja-se, portanto, que nenhuma das partes processuais é responsável pela provocação do Juízo. Nem por isso, a doutrina processual clama pela inconstitucionalidade do dispositivo em comento, já que as medidas listadas são permitidas em nome do interesse público que permeia esse tipo de demanda.

\subsubsection{Evolução histórica do instituto}

Herança dos Códigos Sardos de 1854 e 1859 e do Direito Canônico ${ }^{412}$, a intervenção iussu iudicis foi prevista inicialmente no direito italiano pelo Código de Processo Civil de 1865. Mantendo a estrutura prevista nas legislações de referência, o Código de Processo Civil italiano de 1865 inseriu a intervenção iussu iudicis junto às demais figuras interventivas voluntária e a pedido das partes. A redação do art. 205 do CPC italiano era a seguinte:

L'autorità giudiziaria, se riconosca oportuno l'intervento in causa di un terzo, può ordinarlo anche d'ufficio. In questo caso dichiara nella sentenza a cura di chi la citazione del terzo debba essere fatta, e stabilire il termine per eseguirla.

In ogni caso la citazione può farsi eseguire da qualunque delle parti.

\footnotetext{
412 "Na reorganização das normas dispositivas sobre o Processo Civil do Estado Pontifício, levada a efeito pelo Papa Pio VII, como Motu Proprio de 22 de novembro de 1817, a intervenção de terceiro iussi iudicis foi disciplinada no art. 580. Leão XII, sucessor de Pio VII, promoveu uma nova reforma das ordenações sôbre a administração da justiça civil, pelo Motu Proprio de 5 de outubro de 1824, cujo art. 319 reproduz as disposições do art. 580 do diploma anterior. Dez anos após, o novo Papa Gregório XVI, pelo Motu Proprio de 10 de novembro de 1834, aprovou o Regulamento Judiciário Para as Questões Civis, o qual trata da intervenção necessária de terceiro no processo nos $\S \S 855$ e 856 [...]”. LÔBO DA COSTA, Moacyr. A intervenção iussu iudicis no processo civil brasileiro. São Paulo: Saraiva, 1961. p. 16.
} 
A redação, extremamente criticada pelos juristas contemporâneos ${ }^{413}$, já indicava o critério de oportunidade como - único - requisito para adoção da intervenção pelo juízo. À época ${ }^{414}$, em que o processo civil sequer poderia cogitar a respeito dos influxos de abertura epistemológica provocados pelos direitos fundamentais como vemos atualmente, o dispositivo causava ainda mais estranhamento, principalmente pela falta de indicação acerca de seu propósito ${ }^{415}$. Por conta disso, surgiram diversas teorias acerca da natureza jurídica do instituto.

A primeira delas nasce da robusta obra de Chiovenda e carrega sua contrariedade em relação à violação ao princípio da liberdade de agir em juízo, provocada pela intervenção de ofício ${ }^{416}$. Para Chiovenda, ou a demanda não pode ser proposta em face do réu indicado pelo autor, por falta de legitimidade ad causam, o que ocasionaria sua extinção sem resolução do mérito ${ }^{417}$, ou ela é admissível da forma como proposta e não pode o juiz pretender forçar a composição de um litisconsórcio ${ }^{418}$.

Somente às partes, autor e réu, seria permitida a inclusão de um terceiro na demanda, caso entendessem pela pertinência de sua participação em razão da comunhão de interesses havida com o objeto do processo. A única exceção ficaria por conta da existência de litisconsórcio necessário não observado pelo autor no momento de propositura da

413 Para uma compilação das mais diversas críticas tecidas à época, v. LÔBO DA COSTA. Obra citada. p. 20 , nota 10 .

414 Embora hoje, os questionamentos apresentados ao instituto sejam basicamente os mesmos de então, v.g. "Sviluppare la portata 'eversiva' di tale istituto, o subordinar ela sua applicazione al rispetto del principio dispositivo? Ecco il dilema che si pone ala moderna scienza civilprocessualistica italiana che, all'inizio del secolo, affronta con rinnovata consapevolezza culturale e con mutato rigore dogmatico il tema della chiamata in causa per ordine del giudice". TROCKER, Nicolò. Intervento per ordine del giudice. Milano: Giuffré, 1984. p. 10.

415 "Ponendo come único pressuposto di applicazione il critério vago ed incerto dell'oportunità, i codificatori offrono un contributo assai modesto nel tentativo di precisare [...] la finalità a cui 1 'intervento medesimo risulta predisposto". TROCKER. 1984. p. 5.

416 "Ciascuno è libero d'agire come crede nell'ambito dela legge; e nel processo nessuno può essere costretto a proporre una domanda che non vuol proporre o a proporla contro chi non vuole". CHIOVENDA. 1965. p. 1079.

417 A utilização da expressão do CPC brasileiro é somente uma tentativa de contextualizar a fala do autor, sem que haja prejuízo à ideia original, em decorrência da similaridade de sentidos.

$418 \quad$ "O la domanda non può proporsi contro quel convenuto da solo che fu chiamato in causa o dal solo attore, e in quasto caso si trata di um difetto di legitimatio ad causam che dà luogo a rigetto della domanda; o può proporsi, e in tal caso il giudice non può in alcun modo pretendere che sia proposta anche in confronto dei litisconsorti". CHIOVENDA, Giuseppe. Istituzioni di Diritto Processuali Civile. II. 2. Ed. Napoli: Jovene, 1936. p. 311. 
demanda, quando o juiz teria um poder-dever de rejeitá-la de ofício, como forma de evitar a prolação de uma decisão inútil ${ }^{419}$.

Após concluir pela impossibilidade de utilização da técnica para integração do juízo em caso de litisconsórcio necessário ou em caso de conexão de causas, Chiovenda anota que a única utilidade possível seria valer-se da intervenção iussu iudicis como mecanismo de instrução processual ${ }^{420}$.

O terceiro, portanto, surgiria como um meio de prova a ser utilizado pelo magistrado, sem que lhe fosse dada uma posição concreta dentro do processo, não sendo parte nem testemunha, o que causou estranheza em grande parte dos doutrinadores da época ${ }^{421}$.

Com resguardo ao princípio da liberdade de agir em juízo, Salvatore Satta, em clara homenagem a Chiovenda, tentou aprimorar sua teoria e conduzir a intervenção iussu iudicis a um mecanismo de ampliação do contraditório, com inclusão do terceiro que pudesse, de algum modo, ser atingido pelos efeitos de decisão proferida em processo do qual não tenha participado. Logo, não haveria necessidade de ampliação objetiva da demanda, uma vez que o objeto desta já atrairia, necessariamente, o interesse do terceiro $^{422}$. Vê-se, portanto, que para Satta a intervenção por ordem do juízo não visa a conferir vantagem às partes principais, mas sim ao terceiro, aproximando-se, salvo pela diferença na operacionalização, da assistência - conhecida no direito italiano por intervento adesivo.

Nesse caso, as críticas são dirigidas à desnecessidade de criação de uma nova modalidade que em nada acrescente às técnicas já disponíveis, uma vez que, para Sérgio Costa ${ }^{423}$, as situações práticas vislumbradas por Salvatore Satta receberiam, se muito, meros efeitos

\footnotetext{
419 TROCKER. 1984. p. 13.

420 "Può darsi invece che il giudice riconosca oportuno per il miglior andamento della causa la presenza di un terzo nella lite; poiché la presenza di questo terzo che non diviene parte nella lite, ma vi assiste e ha diritto alla visione degli atti, alle notificazioni ecc., può costitutire una garanzia di più conveniente condotta della causa". CHIOVENDA, Giuseppe. Principii di Diritto Processuale Civile. 3. Ed. Napoli, 1923. p. 731.

421 Conforme anota LÔBO DA COSTA. Obra citada. p. 33, "considerou-se excessivo que um terceiro possa ser incomodado no interêsse da parte, não porque as suas afirmações valham como depoimento, mas para que o juiz, com as cautelas legais, possa deduzir delas simples presunções”.

"la sentenza che si emetterà nel processo farà stato nei confronti del terzo, anche indipendentemente dalla sua partecipazione al processo". SATTA, Salvatore. L'intervento ordinato dal Giudice. In: Scritti di diritto e di economia in onore di Flaminio Mancaleoni. Sassari. Gallizzi, 1938. p. 585.

423 COSTA, Sergio. L'intervento in causa. Torino, 1953. p. 264
} 
reflexos da sentença, jamais apontando similitude suficiente ao objeto da demanda que lhe impusesse a autoridade da coisa julgada.

Lodovico Mortara igualmente refutou o caráter meramente instrutório da intervenção iussu iudicis, tendo-lhe conferido a natureza de intervenção forçada por iniciativa de uma parte $^{424}$. Para ele, assim como Salvatore Satta, a intervenção ocorre em favor do terceiro, que ingressa na lide na condição de parte, podendo apresentar razões para sua exclusão da demanda ou contra qualquer das partes do processo. Assim, a intervenção iussu iudicis serviria à integração da relação processual ${ }^{425}$. Paradoxalmente, após defender a natureza de intervenção forçada da técnica, Mortara destaca que a ordem do juiz não é imperativa, sendo mera sugestão dirigida às partes para inclusão de um terceiro na lide, uma vez que ao juiz seria vedado constranger o terceiro a participar do processo.

Enrico Redenti toma por premissa certo embotamento do princípio da liberdade de agir do autor $^{426}$ e, em contrapartida, um reforço nos poderes corretivos do juiz sempre que a atuação da parte se mostrar desprovida de uma real utilidade ${ }^{427}$. A intervenção por ordem do juízo seria, segundo Redenti, um meio de integração do contraditório nas hipóteses em que houver litisconsórcio necessário ${ }^{428}$. A necessidade da integração adviria da impossibilidade de produção de uma sentença válida, para resolução de problemas relativos a uma relação jurídica material com múltiplos sujeitos, proferida somente na presença de alguns deles.

Quanto ao conteúdo da decisão que dispõe sobre a intervenção iussu iudicis, Redenti defende não se tratar nem de ordem, nem de sugestão dirigida às partes ou ao terceiro. Para ele o juiz somente declara a impossibilidade de sentenciar o processo sem participação (contraditório) de um terceiro, cuja identificação deve apontar. Há um defeito, pois, de legitimidade ad causam.

\footnotetext{
424 MORTARA, Lodovico. Commentario del Codice di Procedura Civile. Vol III. Milano, 1923. P 533 ss.

425 Na leitura de COSTA. Obra citada. p. 42, "porque, se fôsse ordenada com finalidade instrutória, não se vê qual interêsse teria o terceiro para se opor à intervenção. O terceiro poderia alegar não estar em condição de servir ao escopo instrutório; mas, com isso não ficaria legitimada sua rebeldia contra a ordem de intervir, e muito menos se justificaria a necessidade de se proceder ao julgamento sumário do incidente, na forma do art. 451”.

426 Para Nicolò Trocker, a teoria de Redenti é diversa das de Chiovenda e Satta em sua premissa ideal e em seu caráter prático

427 TROCKER. 1984. p. 29.

428 REDENTI, Enrico. Il giudizio civile con pluralità di parti. Milano, 1911.
} 
As críticas formuladas à teoria de Redenti são a incompatibilidade do termo oportunidade usado pelo art. 205 e a natureza do litisconsórcio necessário ${ }^{429}$, bem como a própria distinção havida entre as figuras interventivas e o litisconsórcio necessário ${ }^{430}$.

Francesco Carnelutti leva a intervenção iussu iudicis para o campo do litisconsórcio facultativo, tornando-a mais compatível com o ordenamento jurídico italiano. O termo mais recorrente de sua teoria é o tratamento conjunto de lides conexas ${ }^{431}$. O âmbito de atuação da intervenção por ordem do juízo é, para ele, diverso daquele em que opera o litisconsórcio necessário e tem a ver com a ideia de controvérsia comum entre lides conexas. Para Carnelutti, seria possível que o juiz pudesse agir de ofício, conforme a previsão do art. 205, para determinar a inclusão de um terceiro na lide quando seu objeto versar sobre obrigação solidária ou obrigação indivisível, por exemplo, tornando necessário um litisconsórcio originalmente facultativo.

Pela leitura feita por Nicolò Trocker da teoria carneluttiana, a intervenção iussu iudicis tem lugar quando o litisconsórcio, embora não seja necessário em razão do conteúdo substancial da demanda na forma como proposta, se torne tal em razão do desenvolvimento do processo após a apresentação da defesa do réu que demonstre em juízo a existência de um terceiro em relação ao objeto da demanda ${ }^{432}$.

O perfil da demanda analisada por Carnelutti deixa de ser um juízo único com pluralidade de parte, como em Redenti, e passa a ser um juízo múltiplo ligado pela conexão. Com isso, o enfoque deixa de ser o problema inerente à legitimidade ad causam e passa à conexidade havida entre a demanda apresentada em juízo e outra, cuja existência é deduzida pelo juiz a

\footnotetext{
429 "Questo dúplice criterio di opportunità e di discrezionalità del caso singolo, difficilmente può conciliarsi con la necessità del litisconsorzio e dell'integrazione del contraddittorio affermate in modo generale in relazione alla strutura del rapporto dedotto in giudizio". TROCKER. 1984. p. 36

$430 \quad$ SEGNI, Antonio. L'intervento adesivo. Roma, 1919. p. 213.

431 CARNELUTTI, Francesco. Lezioni di diritto processuale civile. Vol IV. Padova: Univ., 1926. Para TROCKER. 1984. pp. 55-6, 'l'espressione ' trattazione congiunta di liti connesse' protrebbe apparire come un semplice nomen diverso per descrivere la stessa realtà dei 'giudizi unici con pluralità di parti' e la figura dei 'rapporti giuridici connessi' potrebbe sembrare una costruzione meramente sostitutiva di quella dei 'rapporti giuridici di diritto sostanziale unici con pluralià di soggetti'.

432 "si affiancano quei ipotesi in cui la pluralità di parti non è necessaria in ragione del contenuto sostanziale della domanda introdutiva, ma diventa tale in funzione dei concreti svolgimento che assume il processo specie a seguito delle difese del convenuto e del 'coinvolgimento' nel giudizio di un nuovo rapporto riferibile al terzo" TROCKER. 1984. p. 57.
} 
partir dos argumentos apresentados pelas partes ${ }^{433}$. A finalidade da intervenção por ordem do juízo, portanto, é agora a garantia de uma decisão completa e justa ${ }^{434}$, que impõe à demanda originária não apenas uma ampliação subjetiva, mas, igualmente, objetiva.

A grande crítica à teoria carneluttiana foi o alcance dos poderes conferidos ao juiz, para instituir um litisconsórcio necessário como se legislador fosse. Para Salvatore Satta, essa ideia é perigosa e contrária ao princípio da liberdade de agir do autor, ao permitir que o juiz o obrigue a demandar contra quem não queira ${ }^{435}$.

Essas foram as grandes linhas teóricas traçadas pela doutrina italiana durante a vigência do CPC de 1865. O CPC italiano de 1940 manteve a intervenção por ordem do juiz, tendo inserido, porém, o requisito da comunhão de interesse ${ }^{436}$, além de uma estrutura de regulamentação nos artigos $270^{437}, 271^{438}$ e 307 , comma $1^{\text {o439 }}$. A nova previsão legal da intervenção iussu iudicis surgiu no art. 107 do CPC, com a seguinte redação:

433 "quella disposizione [intervenção iussu iudicis] può bene interpretarsi per guisa che, quando il giudice ravvisi opportuno che una lite non sia decisa se non in quanto si decida insieme con essa un'altra alla medesima connessa, possa portare a carico dell'una o dell'altra parte l'onere della proposizione della domanda anche rispetto a questa" Lezione. P. 99.

$434 \quad$ "la completa e giusta decisione". Lezione. P. 107.

435 SATTA. 1938. pp. 582-3. Em sentido contrário à crítica de Satta, fazendo coro à ideia de Carnelutti e Antonio Segni, COSTA. Obra citada. p. 267: “o ônus imposto à parte pelo juiz não é mais grave que o conteúdo da norma que impõe o litisconsórcio necessário".

$436 \quad$ Comunanza di causa

437 Art. 270. (Chiamata di un terzo per ordine del giudice) - La chiamata di un terzo nel processo a norma dell'articolo 107 può essere ordinata in ogni momento dal giudice istruttore per una udienza che all'uopo egli fissa. Se nessuna delle parti provvede alla citazione del terzo, il giudice istruttore dispone con ordinanza non impugnabile la cancellazione della causa dal ruolo.

$438 \quad$ Art. 271. (1) (2) (Costituzione del terzo chiamato) - Al terzo si applicano, con riferimento all'udienza per la quale è citato, le disposizioni degli articoli 166 e 167, primo comma. Se intende chiamare a sua volta in causa un terzo, deve farne dichiarazione a pena di decadenza nella comparsa di risposta ed essere poi autorizzato dal giudice ai sensi del terzo comma dell'articolo 269.

(1) Articolo così sostituito dall'art. 30, L. 26 novembre 1990, n. 353.

(2) La Corte costituzionale con sentenza 23 luglio 1997, n. 260 ha dichiarato l'illegittimità costituzionale del presente articolo nella parte in cui non prevede per il terzo chiamato in causa l'applicazione dell'art. 167, secondo comma, del presente codice.

$439 \quad$ Art. 307. (Estinzione del processo per inattività delle parti) - Se dopo la notificazione della citazione nessuna delle parti siasi costituita entro il termine stabilito dall'articolo 166, ovvero, se, dopo la costituzione delle stesse, il giudice, nei casi previsti dalla legge, abbia ordinata la cancellazione della causa dal ruolo, il processo, salvo il disposto (1) dell'articolo 181 e dell'articolo 290, deve essere riassunto davanti allo stesso giudice nel termine perentorio di tre mesi (2) che decorre rispettivamente dalla scadenza del termine per la costituzione del convenuto a norma dell'articolo 166, o dalla data del provvedimento di cancellazione; altrimenti il processo si estingue.Il processo, una volta riassunto a norma del precedente comma, si estingue se nessuna delle parti siasi costituita, ovvero se nei casi previsti dalla legge il giudice ordini la cancellazione della causa dal ruolo. 
Art. 107. (Intervento per ordine del giudice) - Il giudice, quando ritiene opportuno che il processo si svolga in confronto di un terzo al quale la causa e' comune, ne ordina l'intervento.

Em definição sintetizadora dos elementos da intervenção iussu iudicis, Sérgio Costa os apresenta da seguinte forma: (i) oportunidade e não necessidade da intervenção; (ii) ordem do juiz emitida para a parte; (iii) causa comum ao terceiro (iv) pode ser ordenada em qualquer momento do processo, em primeiro grau de jurisdição ${ }^{440}$.

Com a inclusão do requisito de comunhão de interesse, o CPC italiano de 1940 sepulta, definitivamente, a possibilidade de utilização da intervenção iussu iudicis como meio instrutório $^{441}$, tornando-o um poder discricionário do juiz a serviço do interesse público na economia processual e na diminuição dos riscos de decisões conflitantes ${ }^{42}$. Não passa de mera impressão que a edição do novo código, com indicação de novo requisito para a intervenção de ofício tenha diminuído as dúvidas existentes em relação à técnica.

Para Enrico Tullio Liebman ${ }^{443}$, a nova redação conferida à intervenção iussu iudicis demonstra que a lei pretendeu conferir ao juiz o poder de solicitar a intervenção do terceiro nos casos em que poderia ter sido provocada espontaneamente por qualquer das partes. A ordem de intervenção seria um convite dirigido à parte para que ela possa chamar o terceiro a integrar a lide, seguido da advertência de que a presença do terceiro seria indispensável ao julgamento do processo, de acordo com previsão contida no art. 270 do CPC italiano.

Ainda de acordo com Liebman ${ }^{444}$, a oportunidade referenciada no texto estaria relacionada às seguintes situações: (i) possibilidade de o terceiro tutelar seu interesse que possa ser, indiretamente, atingido pelo julgamento da demanda; (ii) economia processual; (ii) unidade e uniformidade da decisão judicial sobre demandas conexas ${ }^{445}$.

\footnotetext{
$440 \quad$ COSTA. Obra citada. p. 262.

441 IMPERIALI, Stefano. L'ordinanza della corte costituzionale n. 261 del 2006 e l'intervento iussu iudicis nel giudizio di responsabilita' amministrativa. Disponível em: http://www.amcorteconti.it/articoli/imperiali_iussu\%20iudicis.htm. Acesso em 15 de agosto de 2013.

$442 \quad$ ITÁliA. Cass. Civ. II Sez. n. 693 del 1980, Sez. Lav. n. 4000 del 1985, Sez. Lav. n. 5082 del 1995 , I Sez. n. 5983 del 1999.

443 LIEBMAN, Enrico Tullio. Manuale di Diritto Processuale Civile. I. Milano: Giuffré, 1980. P.

158

$444 \quad$ LIEBMAN. 1980. p. 158

445 Em recente julgamento a Corte de Cassação reafirmou seu entendimento sobre as razões que autorizam a intervenção iussu iudicis, a saber: " Al riguardo, questa Corte ha affermato che l'intervento iussu
} 
Nesses casos, o terceiro ingressa no processo na qualidade de litisconsorte necessário. Ou seja, enquanto a inclusão prevista no art. $102^{446}$ tem por causa a necessidade do litisconsórcio, a ordem do juiz respaldada pelo art. 107 a tem por consequência ${ }^{447}$. Caso no curso do processo, a presença de qualquer das partes (seja originária, seja incluída por força de modalidades interventivas) se revele desnecessária ou mesmo intolerável (em decorrência de sua ilegitimidade, por exemplo) é possível que o juiz as retire do processo mediante a extromissão.

Já pela doutrina de Enrico Redenti ${ }^{448}$, a intervenção iussu iudicis, como modalidade de intervenção de terceiro em um processo pendente já e ainda não tem definidos seu escopo e seu momento de utilização pelo magistrado. Segundo escreveu, esses pontos sempre permaneceram controversos na ciência processual, não havendo clareza sobre o assunto. E seu principal questionamento parece retomar a preocupação com o princípio da demanda, apresentado anteriormente por Chiovenda, ao indagar a razão pela qual um terceiro é inserido na relação jurídica processual sem que nenhuma parte tenha intentado propor uma demanda em face deste ou com sua presença ${ }^{449}$.

iudicis, rispondendo all'interesse superiore della giustizia ad attuare l'economia dei giudizi e ad evitare i rischi di giudicati contraddittori - come aie di ordine pubblico e trascendente quello delle stesse parti originarie del giudizio o di terzi- ben può essere disposto (sulla base di una valutazione che costituisce espressione di un potere discrezionale riservato al giudice del primo grado, il cui esercizio non è suscettibile di sindacato nelle fasi successive, né, in particolare, in sede di legittimità) anche nel caso in cui, estraneità al rapporto controverso, il giudice ritenga di dover indurre od autorizzare chi agisce ad estendere la propria domanda nei confronti del terzo indicato come titolare del rapporto medesimo. ITALIA. Cass. 19 gennaio 2004, n. 707. SUPREMA CORTE DI CASSAZIONE SEZIONE III CIVILE Sentenza 7 giugno -13 luglio 2011, n. 15387 (Presidente Morelli - Relatore D'Alessandro). Disponível em: http://www.altalex.com/index.php?idnot=53236.

446 Art. 102. (Litisconsorzio necessario) - Se la decisione non può pronunciarsi che in confronto di piu' parti, queste debbono agire o essere convenute nello stesso processo. Se questo è promosso da alcune o contro alcune soltanto di esse, il giudice ordina l'integrazione del contraddittorio in un termine perentorio da lui stabilito.

447 LIEBMAN. 1980. 159. No mesmo sentido: ARDIZZI, Alberto. L'intervento iussu iudicis nel processo amministrativo. In: Rivista amministrativa della Repubblica italiana. Vol. 159. Fascicolo: 3/4. Parte: 2. 2008. p. 190: "Questa sentenza fa però evidentemente confusione tra i presupposti applicativi del litisconsorzio necessario e quelli dell'intervento iussu iudicis [...] l'ordine di chiamata del terzo a norma dell'art. 107 ha per conseguenza la necessità del litisconsorzio, mentre l'ordine chiamata del terzo a norma dell'art. 102 ha per causa la necessità del litisconsorzio".

448 REDENTI, Enrico. Profili Pratici del Diritto Processuale Civile. 2. ed. rev. Milão:Giuffrè. 1939. p. 261.

“'“La difficoltà è questa: che soltanto le parti possono proporre domande; e soltanto sulle domande proposte può decidere il giudice. Ora, se nessuna delle parti intende proporre domande contro il terzo o nei confronti del terzo, a che farlo intervenire?" REDENTI. 1939. p. 261 
Por essa razão, mesmo após a edição do novo código, Redenti mantém sua teoria segundo a qual a intervenção de ofício serviria para composição dos litisconsórcios necessário ou unitário como forma, apenas, de evitar o desperdício dos atos processuais praticados mediante a extinção do processo ${ }^{450}$ ou a prolação de decisões judiciais contraditórias ${ }^{451}$.

Uma vez, porém, que o terceiro ingresse na relação, passa a ostentar a qualidade de parte, podendo manifestar-se em qualquer sentido, seja apresentando reconvenção ou mesmo não se manifestando, sendo revel ${ }^{452}$.

A visão de Nicolò Trocker mistura os elementos apresentados. Para ele, a previsão da intervenção por ordem do juiz na legislação vigente decorre do concurso de razões. Comunhão de interesses e oportunidade se apresentariam como justificativa para concessão desse poder ao juízo. Pela combinação dos arts. 107 e 207 do CPC italiano, a determinação de ingresso de um terceiro em um processo pendente é deixada à valoração do juiz, o que tornaria juridicamente irrelevantes as razões das partes do processo ${ }^{453}$. Além desse sinal de insatisfação com a flexibilização imposta ao princípio da demanda, Trocker ainda diz que a concessão de autonomia de iniciativa ao juiz não significa que essa medida possa ter lugar sem a colaboração e, mesmo, o controle das partes ${ }^{454}$.

A aplicação do art. 107 exigiria a apresentação de uma questão prejudicial em relação ao objeto litigioso, o que induz forçosamente a ampliação objetiva da demanda, acompanhada pela ampliação subjetiva promovida pela ordem do juiz. Verifica-se, portanto, que o dispositivo importa em um alargamento do limite cognitivo do processo formado pela

$450 \quad$ "crediamo di poter rilevare, che il considdetto intervento d'ufficio, può essere ordinato dal giudice nei casi dei tipi seguenti: prima di tutto, quando sia stata esercitata in giudizio un azione, proponibile od esperibile soltanto contro più parti, senza che tutte siano state chiamate in giudizio. L'ordine di chiamare in questo caso, non sarebbe, se non una forma di sospendere il rigetto e dar modo alle parti di evitare, che vadano per così dire sprecati gli atti già compiuti”. REDENTI. 1939. p. 261.

451 "In secondo luogo può esser ordinato l'intervento, quando [...] quando l'attuazione pratica dei provvedimenti che si chiedono, non possa comunque avvenire, se non col concorso di un terzo. L'autorità giudiziaria può ritenere opportuno, se non necessario, che il terzo sia in giudizio, sebbene non ci siano domande contro di lui, all'effetto di assicurare la pieno efficacia pratica della sentenza, che essa sia per pronunciare”. REDENTI. 1939. p. 262.

$452 \quad$ REDENTI. 1939. p 262

453 TROCKER. 1984. p. 443-4. Em complemento à ideia: "L'intervento di cui all'art. 107 c.p.c. si sottolinea, è meccanismo rimesso al potere autoritativo del giudice che può trovare applicazione ed impiego 'senza bisogno dell'impulso di parte'” TROCKER. 1984. p.446.

454 TROCKER. 1984. p. 448-9. 
atuação das partes e pelo desenvolvimento processual que ela proporciona. Logo, pode-se falar que a atuação do juiz condiciona a das partes ${ }^{455}$.

Apesar de sua aparente resistência à superação do princípio da demanda, Nicolò Trocker apresenta suas justificativas para o fato. De acordo com sua doutrina, a iniciativa do juiz que ordena a intervenção do terceiro no processo tem dupla finalidade, não se prestando apenas a proporcionar o conhecimento do interesse do terceiro, mas igualmente a submetêlo ao contraditório daqueles que se apresentam como titulares desse interesse na demanda originária.

Essa postura seria desarmônica em relação a mais rígida compreensão do princípio da demanda. Porém, para Trocker, ela se justifica pela importância em conferir maior certeza ao direito e maior justiça ao resultado. Por isso, a intervenção iussu iudicis pode ser melhor compreendida tomando-se por premissa a construção progressiva da controvérsia no iter processual, já que nem sempre as partes são capazes de apresentar a demanda com todos os elementos necessários à sua resolução ${ }^{456}$.

Assim, no decorrer da relação jurídica processual, o juiz poderia interagir com as partes, podendo inclusive emitir a ordem de intervenção do terceiro, que não é dirigida diretamente a este (a exemplo das decisões previstas nos artigos 118 e 210 do CPC italiano), mas sim, a uma ou ambas as partes do processo. A estas incumbe promover a integração do terceiro ao processo pendente. Essa estrutura decorre do disposto no art. 270, comma $2^{\circ}$ do CPC italiano, que indica que a citação é o mecanismo pelo qual deve ser promovida a intervenção iussu iudicis ${ }^{457}$.

A estrutura processual da intervenção iussu iudicis atribui ao juiz o poder de condicionar em razão da presença de comunhão de interesses e de oportunidade - a prolação de decisão de mérito a uma ampliação subjetiva e, eventualmente, também objetiva do processo. Para Trocker, isso equivale a dizer que ao juiz é dado o poder de criar uma condição de julgamento da demanda, declinando de pronunciar-se em relação à controvérsia estabelecida entre os sujeitos presentes na lide se a essa não comparece um outro, o

\footnotetext{
455 TROCKER. 1984. p. 451.

456 TROCKER. 1984. p. 453-4.

457 TROCKER. 1984. p. 122-3.
} 
terceiro. Apesar dessa limitação ao princípio da demanda, Trocker destaca que não existe demanda proposta de ofício, nem substituição das partes pelo juiz ${ }^{458}$.

Nas situações em que ocorre a intervenção de ofício, há previsão unicamente de que, no confronto dos sujeitos processuais que tenham invocado a tutela jurisdicional por iniciativa própria, venha a ser limitado o poder de determinar livremente os limites subjetivos e, eventualmente, objetivos do processo. Para o terceiro, a coação que caracteriza a intervenção forçada por ordem do juiz não é fenômeno diverso daquele pelo qual o réu é forçado a comparecer em juízo ${ }^{459}$.

Após consentir com a flexibilização do princípio da demanda, justificada por interesses superiores aos das partes, Trocker defende a possibilidade de sua utilização mesmo em processo que veiculam direitos estritamente individuais e privados. Segundo ele, o respeito do ordenamento jurídico à autonomia dos indivíduos para definição de suas demandas judiciais não impede sua conjugação com outros interesses. Enquanto o direito de ação é definido pela vontade do autor, no desenvolvimento do processo surge o interesse público, igualmente digno de tutela, à correta atuação da função jurisdicional e à justiça da decisão a ser proferida $^{460}$.

Em regra somente duas partes fazem parte do processo em sua origem, porém, é possível que no decorrer do processo surja a incerteza acerca da identidade exata do sujeito passivo da demanda, seja em decorrência dos elementos adquiridos durante a instrução ou mesmo pelos argumentos apresentados pelo réu em sua resposta, ao fazer menção à existência de terceiro ou mesmo ao negar sua condição de legitimado passivo. Por vezes, essa negativa é formulada conjuntamente com a indicação do verdadeiro legitimado ${ }^{461}$.

458 TROCKER. 1984. p. 124. Igualmente, para COSTA. Obra citada. p. 267 “me parece [...] que seja inadmissível uma intervenção sem uma demanda, porque representaria um retorno à figura da quasi-demanda e, consequentemente, de quasi-parte; (ii) como destacado por Carnelutti e Segni, o ônus imposto à parte pelo juiz não é mais grave que o conteúdo da norma que impõe o litisconsórcio necessário".

$459 \quad$ TROCKER. 1984. p. 125.

460 TROCKER. 1984. p. 126.

461 TROCKER. 1984. p. 168-9. Em recente julgamento, a Corte de Cassação corroborou o entendimento de Trocker. "Qualora il giudice ordini l'intervento di un terzo a seguito delle difese svolte dal convenuto, il quale, contestando la propria legittimazione passiva, indichi quello come responsabile della pretesa fatta valere in giudizio, ricorre un'ipotesi non di litisconsorzio necessario, ex art. 102 cod. proc. civ., ma di chiamata in causa "iussu iudicis ", ai sensi dell'art. 107 cod. proc. civ., rispondente ad esigenze di economia processuale (comunanza di causa), discrezionalmente valutate sotto il profilo dell'opportunità. Ove, peraltro, la notifica al terzo sia nulla (nella specie, per mancata spedizione, a seguito di notificazione a mezzo del servizio postale, dell'ulteriore avviso per raccomandata imposto da Corte cost. 22 settembre 1998, n. 346), il contraddittorio non può ritenersi validamente instaurato, restando sanata detta nullità soltanto 
Gian Antonio Michele, com base na doutrina de Carnelutti, afirma ser claro como a intervenção provocada pelas partes e a ordenada de ofício pelo juiz devem ser consideradas como semelhantes e o terceiro, necessariamente legitimado, teria legitimação igual àquela das partes processuais. Essa igualdade, inerente aos elementos objetivos (pedido e causa de pedir) de cada pretensão, justificaria a exceção ao princípio da demanda por exigência de economia processual $^{462}$.

Para Michele, a dúvida reside justamente na extensão do reconhecimento do interesse do terceiro na controvérsia, ou seja, qual seria o elemento suficiente para determinar a legitimidade passiva do terceiro a ser incluído no processo por força da intervenção iussu iudicis. A jurisprudência italiana parece considerar legitimado o terceiro em cujo confronto o provimento judicial produza seus efeitos jurídicos. Porém, como bem destaca Michele, a noção de extensão do julgamento ao terceiro nem sempre é bem nítida, variando entre o terceiro que seja genericamente interessado em apresentar oposição e aquele interessado em apresentar assistência, apenas reforçando os argumentos já utilizados na demanda existente entre as partes processuais ${ }^{463}$.

Dois interesses podem conduzir à utilização da intervenção iussu iudicis (i) a preocupação de fazer participar em juízo quem estaria sujeito à decisão de mérito; (ii) ou a vontade de se evitar a duplicidade de julgamentos - embora não sendo o terceiro sujeito da sentença prolatada entre as partes, teria interesse em sua resolução. A opção por um desses fundamentos indicaria qual o terceiro poderia ser inserido no processo por ordem do juiz $^{464}$.

Ainda segundo Gian Antonio Michele, para a exata avaliação do instituto é preciso aceitar que o juiz possa derrogar o princípio da demanda, trazendo para a causa um terceiro

dall'ordine giudiziale di rinnovazione o dalla spontanea reiterazione, ad opera della parte interessata, della notificazione della citazione al terzo, senza che possa, invece, assumere rilievo sanante l'eventuale notifica al terzo stesso di un ricorso per riassunzione conseguente all'interruzione del processo pendente tra le parti originarie, in quanto atto mancante degli elementi essenziali della domanda estesa nei confronti di quello. ITALIA. Corte di Cassazione, Sez. 2, Sentenza n. 315 del 09/01/2013. Disponível em: http://www.foroeuropeo.it/index.php/civile-procedura/37495-civile-intervento-in-causa-del-terzo-coattoiussu-iudicis-chiamata.

462 MICHELE, Gian Antonio. Opera Minori di Diritto Processuale Civile. Vol. I. Milão: Giuffrè, 1982. p. 360-1.

463 MICHELE. Obra citada. p. 363-4.

464 MICHELE. Obra citada. p. 365-5. 
interessado na controvérsia, quando possa, dessa forma, evitar um conflito prático entre julgados. As razões fincadas na economia processual são, igualmente, determinantes para definição da intervenção de ofício, que serviria, em sua opinião, para integração do contraditório e complementação de um litisconsórcio meramente facultativo ${ }^{465}$.

Michele é outro defensor do interesse público como autorizador da intervenção iussu iudicis. Para ele, ainda quando a lei não apresente previsão expressa de integração obrigatória (como no caso do litisconsórcio necessário), o ingresso do terceiro pode ser admitido quando sua ausência possa ser danosa, de acordo com a avaliação feita pelo juiz, ao interesse do próprio sujeito ${ }^{466}$.

Embora apresente argumentos favoráveis ao ingresso do terceiro por ordem do juiz, Michele não admite a ampliação objetiva da demanda. Para ele, o requisito da igualdade dos elementos objetivos da demanda deve ser rigorosamente avaliado para que possa haver a intervenção iussu iudicis, já que se a comunhão genérica de interesses fosse suficiente a legitimar uma parte a chamar um terceiro ao processo, não pareceria aceitável a intervenção por ordem do juiz, já que a iniciativa de ofício deve ser justificada nos estreitos limites autorizativos da técnica ${ }^{467}$.

\subsubsection{Reflexos sobre o princípio da demanda}

O impacto da intervenção iussu iudicis no princípio da demanda sempre foi objeto de discussão na doutrina italiana. Para Giorgio Constantino, o princípio da demanda não exclui a sua extensão de ofício, até porque esta não se traduz por controvérsias entre sujeitos, mas sim, controvérsias entre pretensões ${ }^{468}$. Logo, é bem possível que o juiz venha a acreditar que não possa decidir corretamente sobre os pontos controvertidos senão pelo confronto entre a posição das partes e a posição de um terceiro vinculada ao juízo.

\footnotetext{
465 MICHELE. Obra citada. p..365. Em complemento, afirma COSTA. Obra citada. p. 272: "no caso da intervenção iussu iudicis, o legislador quis que o juiz fosse inspirado por um princípio superior ao interesse da parte - o interesse da justiça. $\mathrm{O}$ juiz em seu poder discricionário pode em qualquer momento ordenar a intervenção de um terceiro e pode, uma vez proposta a demanda, se se revela demais gravosa a permanência do terceiro na causa, ordenar a separação da causa com base no art. 103 do CPC". Para ARDIZZI. Obra citada. . 191, "L'argomento decisivo in tal senso sembra la duplice ratio di rispetto del principio di economia dei giudizi e del fine di evitare un potenziale conflitto di giudicati”.

466 MICHELE. Obra citada. p. 367.

467 MICHELE. Obra citada. p..369.

468 CONSTANTINO, Giogio. Intervento del processo: diritto processuale civile. In: Enciclopedia giuridica. Roma: Instituto della Enciclopedia Italiana, 2007. 9p. v. 19.
} 
Não são grandes os problemas quando o juiz de primeiro grau ordena a intervenção do terceiro cotitular do mesmo direito ou obrigação deduzido em juízo ou do terceiro titular de situação jurídica dependente à da demanda; porque nestas hipóteses, haveria uma mera extensão subjetiva, e não objetiva, dos limites do processo. No caso, porém, em que seja ordenada a intervenção do terceiro titular de situação jurídica alternativa àquela deduzida em juízo pelas partes originárias, a ele somente serão estendidos os efeitos da decisão proferida inter partes, ou seja, a situação jurídica titularizada pelo terceiro não poderá ser objeto de apreciação nos mesmos autos ${ }^{469}$.

Apresentando maiores detalhes Andrea Proto Pisani afirma ser mínima ou, até mesmo, nula, a compressão do princípio da demanda nas hipóteses em que haja conexão por prejudicialidade, em que a pretensão do terceiro for juridicamente dependente do objeto do processo originário e conexão por identidade de objeto e de título (o terceiro seria cotitular de pretensão plurissubjetiva já objeto do processo originário), uma vez que a ordem do juiz incidiria somente na qualidade dos efeitos da decisão ao submeter a lide ao confronto com o terceiro, mas, mantendo intocado o objeto da demanda originária ${ }^{470}$.

Nos casos em que houver conexão por prejudicialidade em decorrência da relação da prejudicialidade havida entre a pretensão deduzida em juízo e aquela titularizada pelo terceiro, Proto Pisani crê que essa compressão seja bastante tênue porque a pretensão titularizada pelo terceiro já deveria ser conhecida incidenter tantum pelo juiz. Porém, nas hipóteses em que houver conexão por identidade de elemento objetivo ou por alternatividade a derrogação do princípio da demanda é tão nítida, que sua convivência no ordenamento com a intervenção iussu iudicis somente pode ser justificada se houver pedido expresso da parte que tenha perdido seu direito (por preclusão) de solicitar a intervenção de terceiro e o juiz verifique que a preclusão teve por causa fato não imputável a essa parte ${ }^{471}$.

Para Antonio Costa, em regra, a intervenção de terceiro não viola nem comprime o princípio da demanda, já que a decisão proferida pelo juiz seria dirigida às partes e não ao

\footnotetext{
469 CONSTANTINO. Obra citada..

$470 \quad$ PROTO PISANI, Andrea. Appunti sul litisconsorzio necessario e sugli interventi. In: Rivista di Diritto Processuale. Anno XLIX. 2. ed. n. 1. jan-mar, 1994. p. 375.

$471 \quad$ PROTO PISANI. 1994. p. 375.
} 
terceiro $^{472}$. Luigi Paolo Comoglio, Corrado Ferri e Michele Taruffo defendem que o ato pelo qual o juiz determina a intervenção do terceiro sequer seria uma ordem, mas somente uma sugestão dirigida às partes. Nessa oportunidade, o juiz somente pode sugerir a inclusão do terceiro no processo, jamais a propositura de uma demanda em face dele ${ }^{473}$.

Esse é o entendimento predominante na doutrina processual italiana. Considerando que a ordem judicial pela qual o juiz materializa a intervenção iussu iudicis não é dirigida ao terceiro e sim às partes, a sua inclusão se dá por prática de ato direto das partes e não do juiz.

\subsubsection{Papel do terceiro}

Ao ingressar na lide, o terceiro assume a posição de parte mesmo no caso em que não proponha e não seja destinatário de nenhuma demanda, e passa a estar vinculado à decisão sobre o objeto do juízo ${ }^{474}$.

Embora os processualistas concordem que o terceiro assuma qualidade de parte, há sempre a ressalva quanto à possibilidade de o juiz determinar a instauração de demanda contra o terceiro. No entanto, de acordo com Alberto Ardizzi, a doutrina dominante hoje conclui que o terceiro chamado se torna parte do juízo e que, então, o ato que determina sua inclusão no processo contém uma verdadeira demanda no confronto do terceiro que resulta, assim, assujeitado à decisão. Parece claro, assim, que a comunhão de interesses atua como elemento legitimador do instituto da intervenção iussu iudicis ${ }^{475}$.

\footnotetext{
$472 \quad$ COSTA. Obra citada. p. 469.

473 COMOGLIO, Luigi Paolo; FERRI, Corrado; TARUFFO, Michele. Lezioni sul processo civile. 2. Ed. Bologna: Mulino, 1998. p. 317.

474 CONSTANTINO. Obra citada.. No mesmo sentido: "Il terzo chiamato in causa per ordine del giudice diviene parte anche se non vengono proposte domanda contro di lui o lui non ne propone e viene quindi ad essere soggeto all'efficacia diretta della sentenza". COMOGLIO, Luigi Paolo; FERRI, Corrado; TARUFFO, Michele. p. 317. PROTO PISANI. 1994, com explicações mais detalhistas anota o seguinte: "Quanto ai poteri processuali dei terzo chiamato in causa, è da ritenere che nell'ipotesi di terzo titolare di un rapporto giuridicamente dipendente da quello dedotto in giudizio dalle parti originarie, essi saranno dei tutto corrispondenti a quelli dell'interveniente volontario ex art. $105,2^{\circ}$ comma. Nell'ipotesi invece di chiamata in causa per ordine dei giudice di un terzo nei cui confronti è proposta una domanda (eventualmente di mero accertamento) connessa con quella originaria, i poteri processuali dei terzo saranno quelli propri di ogni soggetto nei cui confronti è proposta una domanda giudiziale. Poiché in questi casi attraverso la chiamata in causa per ordine dei giudice si propone una. vera e propria domanda giudiziale nei confronti dei terzo e non una mera denunciatio litis, ne discende da un lato che il terzo, ove non si costituisca, sarà da considerare a tutti gli effetti contumace, dall'altro lato che nei confronti dei terzo si emanerà in ogni caso una sentenza destinata ad esplicare efficacia immediata nei suoi confronti. PROTO PISANI. 1994. p. 376.
}

$475 \quad$ ARDIZZI. Obra citada. p. 192. 


\subsubsection{Proposta de novo código de processo civil italiano}

Andrea Proto Pisani apresentou, em 2009, proposta de um novo Código de Processo Civil italiano. As matérias relativas a litisconsórcio, cúmulo de demandas, intervenções de terceiros e sucessão processual foram todas unidas em um só capítulo. Dentro da matéria de intervenção, foram mantidas as modalidades voluntária, por iniciativa da parte e por ordem do juiz. Dentre as previsões contidas nesse anteprojeto está, portanto, a intervenção iussu iudicis, que apesar de muitas dúvidas e críticas geradas na doutrina processualista, ainda permanece gerando interesse do legislador. No item 1.22 de sua proposta, a intervenção por ordem do juiz permanece submetida ao critério de oportunidade do juiz, com esclarecimento de que serve ao melhor funcionamento da dialética processual. $\mathrm{O}$ terceiro sujeito a essa ordem seria aquele titular de direito ou obrigação prejudicial ou dependente ou conexo por identidade de objeto em relação ao processo originário ${ }^{476}$.

Não é possível crer que uma técnica processual possa permanecer durante quase cento e cinquenta anos, passando por duas reformas processuais e uma nova proposta, sem que tenha utilidade para o ordenamento jurídico.

\subsubsection{Intervenção iussu iudicis na França}

A intervenção iussu iudicis está prevista no ordenamento francês como técnica disponível aos processos civil e penal. Para a área cível, há previsões constantes tanto no code de procedure civile como no code civile.

No Código de Processo Civil francês, foi inserida ao lado das intervenções forçadas ${ }^{477}$ (mise en cause), que estão dispostas nos arts. 331 a 333. A disciplina da intervenção por

476 “1.22 Intervento per ordine del giudice. - Il giudice dispone l'intervento di terzi quando ritiene opportuno, per il miglior funzionamento della dialettica processuale, che un terzo titolare di un diritto od obbligo pregiudiziale o dipendente, ovvero connesso per identità di oggetto e di titolo con quello del processo originario, partecipi al processo". PROTO PISANI, Andrea. Per un nuovo codice di procedura civile. Disponível em: https:/ /www.academia.edu/210012/Andrea_Proto_Pisani_Il_progetto_di_un_nuovo_codice_di_procedura_civile_2 009. Acesso em: 03 de julho de 2013.

477 "Plus radicalement encore, les tiers, initialement étrangers à l'instance, en tout ou en partie, peuvent y devenir parties. Les mécanismes sont nombreux qui permettent cette mutation. Ce changement de qualité peut être l'effet, passif, d'une transmission de l'action, par exemple em cas de décès d'une partie ou de cession de créance. Ce peut être également le résultat d'une initiative procédurale des tiers (intervention 
ordem do juiz está prevista, especificamente, no art. 332, que dispõe sobre a intervenção realizada para o procedimento contencioso (primeira parte) e o voluntário (segunda parte $)^{478}$.

A primeira parte, que trata da intervenção iussu iudicis no procedimento contencioso deve ser interpretada em conjunto com o art. 768-1 $1^{479}$, que dispõe sobre a autoridade competente para determiná-la (juiz da instrução processual) e o procedimento a ser adotado (sugestão endereçada às partes). Já a segunda parte, relativa ao procedimento voluntário, confere ao juiz o poder de ordenar a inclusão do terceiro.

Igual poder é conferido ao juiz pelo Código Civil francês em seu art. $324^{480}$, que o autoriza a ordenar de ofício a inclusão de terceiros interessados em demandas que veiculem matéria relativa a filiação.

Veja-se, portanto, que a intervenção pode ser procedimentalizada de duas formas no direito italiano: por sugestão dirigida às partes e por ordem de ofício, a depender da matéria tratada processualmente. A divisão, obviamente, deriva da mesma discussão observada no direito francês, qual seja, a violação do princípio da demanda.

No direito processual francês, a limitação objetiva da demanda é apresentada de forma mais clara que no direito brasileiro. No art. $4^{\circ}$ do CPC francês, é possível verificar que o objeto do litígio é determinado pelas pretensões das partes, que são fixadas pela petição inicial e pela resposta do réu. O objeto do litígio pode ser, no entanto, alterado por demandas incidentais desde que ligadas à original por um vínculo forte o bastante ${ }^{481}$.

volontaire, exercice d'um recours, voire action référé), des parties (intervention forceé de tiers), voire du juge lui-même (mise en cause des tiers em matière civile, mise en examen en matière penale)". CADIET. Obra citada. p. 725.

$478 \quad$ Article 332

Le juge peut inviter les parties à mettre en cause tous les intéressés dont la présence lui paraît nécessaire à la solution du litige.

En matière gracieuse, il peut ordonner la mise en cause des personnes dont les droits ou les charges risquent d'être affectés par la décision à prendre.

479 Article 768-1 Le juge de la mise en état peut inviter les parties à mettre en cause tous les intéressés dont la présence lui paraît nécessaire à la solution du litige.

$480 \quad$ Article 324 Les jugements rendus en matière de filiation sont opposables aux personnes qui n'y ont point été parties. Celles-ci ont le droit d'y former tierce opposition dans le délai mentionné à l'article 321 si l'action leur était ouverte.

Les juges peuvent d'office ordonner que soient mis en cause tous les intéressés auxquels ils estiment que le jugement doit être rendu commun.

Article 4 En savoir plus sur cet article...

L'objet du litige est déterminé par les prétentions respectives des parties. 
Por sua vez, $o$ art. $5^{\circ}$ aponta expressamente a vinculação do juiz às pretensões formuladas pelas partes, com clara resistência à ampliação objetiva da demanda (consagração do princípio da congruência) ${ }^{482}$.

Como o direito francês concilia, então, essas disposições com a intervenção iussu iudicis? Da mesma maneira que os italianos, ao considerar que a ordem é emitida às partes e não ao terceiro, deixa-se de acreditar que haja concessão de poderes indevidos ao juiz, somente sendo autorizada sua atuação de ofício em situações em que não haja litígio (procedimento voluntário) ou em razão de interesse público superior na resolução da demanda (matéria de filiação).

Um ponto, no entanto, precisa ser considerado. Quando o art. $4^{\circ}$ permite a alteração dos limites objetivos da demanda em decorrência das demandas incidentais que surjam no curso do processo, há aí abertura suficiente para que a intervenção de terceiro possa alargar o objeto da lide. Isso porque, como bem destacado por Serge Guinchard, a intervenção provocada é justamente uma demanda incidental que deve estar ligada à principal por um vínculo suficiente a autorizá-la ${ }^{483}$.

Para a doutrina processual, somente as partes têm o poder de inserir na demanda um terceiro, a fim de submetê-lo ao julgamento proferido, seja por vontade própria ou por iniciativa do juiz. Assim, embora o juiz não possa inserir, por ato próprio, o terceiro na lide, ele dispõe dos poderes (ou seriam faculdades?) a ele conferidos pelo art. 332. No procedimento voluntário, não se discorda da possibilidade de inserção direta do terceiro no processo pelo próprio juiz. Porém, no procedimento contencioso, a doutrina diz ter sido o código mais prudente, ao conferir ao magistrado somente a faculdade de sugerir às partes a inclusão do terceiro ${ }^{484}$.

Ces prétentions sont fixées par l'acte introductif d'instance et par les conclusions en défense. Toutefois l'objet du litige peut être modifié par des demandes incidentes lorsque celles-ci se rattachent aux prétentions originaires par un lien suffisant.

${ }_{482} \quad$ Article 5 En savoir plus sur cet article...

Le juge doit se prononcer sur tout ce qui est demandé et seulement sur ce qui est demandé.

483 L'intervention forcée était une demande incidente, elle doit se rattacher aux prétention des parties par um lien suffisant. GUINCHARD, Serge. Droit et ratique de la Procédure Civile. 6. Ed. Paris : Dalloz, 2009. p. 624.

484 "Seules les parties à une procédure peuvent mettre en cause un tiers que ce soit aux fins de condamnation ou en déclaration de jugement commum. Mais toutes les parties disposent de cette prérogative, y compris celles intervenues ou mise en cause précédemment. Elles peuvent agir spontanément ou à l'initiative du juge. En effet, si le juge ne peut pas lui-même mettre en cause un tier dans la procédure dont il 
No entanto, a jurisprudência avança um pouco mais. Em procedimento contencioso, já foi autorizado $^{485}$ ao juiz proferir uma injonction em vez de uma simples invitation. Assim como na Itália, os tribunais franceses são mais receptivos à técnica da intervenção iussu iudicis que a doutrina processual.

A doutrina francesa, por força das decisões judiciais, acaba por fazer concessões. Serge Guinchard admite que, na prática, pouca diferença faz entre conferir ao juiz poder de emitir uma injonction ou uma invitation, uma vez que pela jurisprudência atual, o juiz não pode condenar um terceiro quando, embora tenha sido determinada sua intervenção iussu iudicis, ele não tenha sido inserido na demanda por qualquer das partes. Logo, os efeitos práticos da intervenção iussu iudicis são os mesmos daquela originada por vontade das $\operatorname{partes}^{486}$.

Portanto, a despeito das previsões e restrições contidas nos arts. $4^{\circ}, 5^{\circ}$ e $768-1$ do CPC francês, a intervenção iussu iudicis tem sido utilizada com a mesma força das demais modalidades interventivas previstas no direito francês.

\subsubsection{Intervenção iussu iudicis no Brasil}

No Brasil, o CPC de 39 dispunha de previsão semelhante em seu art. 91, que exibia a seguinte redação: “o juiz, quando necessário, ordenará a citação de terceiros, para integrarem a contestação. Se a parte interessada não promover a citação no prazo marcado, o juiz absolverá o réu da instância”.

A redação do artigo parece ignorar toda a discussão travada na experiência italiana acerca da finalidade da intervenção iussu iudicis. A fazer referência ao termo "quando

est saisi, il dispose désormais, en la matière, d’un large pouvoir d’initiative prévu à l'article 332 . En matière gracieuse, il peut toujours ordonner la mise en cause des personnes dont les droits ou les charge risquent d'être affectés par la decision à prendre. En matière contentieuse, l'article 332, alinea 2C. Pr. Civ. est plus prudent. Il n'autorise le juge qu'à inviter les parties à mettre en cause tous les intéressés dont la présence lui parait nécessaire à la solution du litigie". GUINCHARD. Obra citada. p. 625

485 ITALIA. Civ. 3e, 6 oct. 1993, no 91-15.728. Bull, civ III n ${ }^{\circ} 118$; JCP 1993, IV, 2540 ; RTD civ 1994, 163, obs. R. Perrot.

$486 \quad$ GUINCHARD. Obra citada. p. 625 
necessário", o legislador indicou, equivocadamente, que a técnica serviria para integrar o litisconsórcio necessário, seguindo a ideia superada de Enrico Redenti ${ }^{487}$.

Essa vinculação da intervenção de ofício ao litisconsórcio necessária, derivou, seguramente, do apego aos princípios da demanda e dispositivo, tão caros aos processualistas da época, que não poderiam imaginar tamanha flexibilização, senão em prol da integração do litisconsórcio necessário. Sua perpetuação pela doutrina contemporânea tomou como argumento central a inserção da intervenção iussu iudicis no capítulo relativo ao litisconsórcio e não naquele que tratava da intervenção de terceiros.

Em relação à localização do artigo, Moacyr Lôbo da Costa explicou que, primeiramente, os erros técnicos praticados pelo legislador seriam bastante conhecidos para serem ignorados, mas que, apesar disso, era possível explicar a localização do art. 91 no capítulo destinado ao litisconsórcio em decorrência de seus efeitos, ou seja, a instauração de um litisconsórcio, formado a partir do ingresso do terceiro na lide ${ }^{488}$. Ademais, a integração do litisconsórcio necessário é obrigação do juiz, ao passo que a determinação de ingresso de terceiro no processo fica a cargo da discricionariedade do juiz ${ }^{489}$.

Feita a distinção, Moacyr Lôbo da Costa pontua que a intervenção iussu iudicis se prestaria, no direito brasileiro, a integrar processualmente o litisconsórcio facultativo próprio $^{490}$ que, apesar de não ser necessário, deriva igualmente da comunhão de interesses. Essa compreensão também era dificultada durante a vigência do CPC de 1939, uma vez mais por atecnia do legislador. O art. 88, que disciplinava o litisconsórcio, indicava de

487 Em verdade, esse entendimento equivocado ainda apresenta adesões, a exemplo do voto proferido pelo Ministro Marco Aurélio Mello duranto o julgamento da Petição n 3388-4/RR (Demarcação de terras das Reservas indígenas Raposa-Serra do Sol), onde ficou evidenciado: "É a figura da intervenção iussu iudicis expressamente prevista no artigo 91 do Código de Processo Civil de 1939, já admitida pela doutrina e por este Tribunal, e que se encontra presente nos artigos 47, parágrafo único, 48 e 49 do Código Buzaid - o de 1973"

488 LÔBO DA COSTA. Obra citada. p. 123. Em afirmação mais incisiva, o autor reforça: “A ubicação do art. 91, porém decorrendo de um êrro de técnica do autor do anteprojeto do Código, não pode ser invocada como argumento para caracterizar a natureza jurídica do instituto a que se refere”. LÔBO DA COSTA. Obra citada. p. 127.

489 "o critério de apreciação dessa oportunidade é confiado ao prudente arbítrio do magistrado, em face da conta de concreta de lei que deve incidir”. LÔBO DA COSTA. Obra citada. p. 135.

490 Dentre os exemplos mais frequentes de litisconsórcio facultativo próprio, estão as obrigações indivisíveis e as solidárias. 
maneira incorreta que somente no litisconsórcio necessário haveria comunhão de interesses $^{491}$.

Com essa feição, a intervenção iussu iudicis acaba por criar uma figura intermediária entre o litisconsórcio necessário e o litisconsórcio facultativo, na linha da teoria carneluttiana. Uma vez instaurado, o litisconsórcio facultativo próprio não poderia ser recusado, conforme destacava o art. 88, segunda parte, do CPC de 1939. Porém, se por falta atribuível ao autor, a demanda for instaurada sem a participação dos litisconsortes, ao juiz era conferido o poder de determinar sua citação, sob pena de absolvição de instância.

Mas, para além do litisconsórcio fundado na comunhão de interesses, Moacyr Lôbo da Costa destaca que a intervenção iussu iudicis tem perfeita aplicação nos casos de litisconsórcio facultativo por conexão de causas ${ }^{492}$, quando a utilização da técnica serve para evitar a prolação de decisões contraditórias, mormente quando haja a possibilidade de geração de direito de regresso em face de terceiros. Nesses casos é que fica mais evidente a flexibilização do princípio da demanda ${ }^{493}$ - embora, para muitos, a intervenção iussu iudicis, assim como entendido na doutrina italiana, não violava o princípio da demanda porque o juiz não incluía o terceiro, mas determinava à parte que ela promovesse a inclusão $^{494}$.

Acontece que, por mais um equívoco cometido pelo legislador, o CPC de 1939 não continha previsão de formação de litisconsórcio com base na conexão de demandas, embora o conceito fosse de conhecimento geral da doutrina e da jurisprudência da época, tomada em consideração a lição de Pescatore.

\footnotetext{
$491 \quad$ Equívoco não repetido na redação do art. 46 do CPC de 1973.

492 LÔBO DA COSTA. Obra citada. p. 141.

493 Seguindo a ideia de (ver quem fala isso), Moacyr Lôbo da Costa não vê problemas em conferir ao juiz poderes semelhantes aos atribuíveis ao legislador. Para reforçar sua ideia, vale-se dos mesmos objetivos expostos pela doutrina processualista italiana, quais sejam, evitar decisões judiciais conflitantes e promover a economia processual.

$494 \quad$ Nesse sentido, William Couto Gonçalves escreveu: “ocorre, contudo, que nem mesmo no caso de intervenção iussu iudicis do Código pretérito o princípio dispositivo [da demanda] era inobservado uma vez que o comando do juiz recaía, como sói acontecer hoje com o litisconsorte necessário, sobre a parte para que esta promovesse a integração do terceiro no contraditório em razão da comunidade de causas, por questão de oportunidade, ou em razão de litisconsorciação necessária, por questão de imprescindibilidade. É o que se pode extrair, também, do cotejo dos arts. 102 e 107 do Codice di Procedura Civile italiano, fontes daquele dispositivo do Código mais anoso e não mais vigente". GONÇALVES, William Couto. Intervenção de terceiros. Belo Horizonte: Del Rey, 1997. p. 49.
} 
Nesses casos, lembra Moacyr Lôbo da Costa, embora o terceiro não se submeta à autoridade da coisa julgada, a sentença que reconhecer sua culpa irá influir decisivamente em futura ação regressiva que contra si possa ser movida. Porém, caso esse mesmo terceiro disponha de provas contundentes que demonstrem inexistir sua culpa, haverá um cenário jurídico completamente contraditório, criado por provimentos jurisdicionais ${ }^{495}$.

Após a edição do CPC de 1973, o ordenamento jurídico brasileiro abandonou, definitivamente, a possibilidade de o juiz atuar de ofício, interferindo na autonomia das partes para desenhar os limites objetivos e subjetivos de sua demanda. Somente as figuras interventivas já mencionadas anteriormente passaram a ser aceitas como técnicas capazes de incluir um terceiro em um processo pendente inter alios.

Obviamente, tendo o CPC de 1973 sido escrito e aprovado sob o signo das liberdades individuais, as figuras interventivas contemplam apenas a iniciativa das partes (intervenções provocadas ou coatas) e do próprio terceiro (intervenções voluntárias), em homenagem ao princípio da demanda, que decorre, diretamente, do art. $2^{\text {o }}$ do Código ${ }^{496}$.

A inércia da jurisdição, como conceito decorrente da imparcialidade do juiz, foi tomada como absoluta impossibilidade de manipulação, por parte deste, dos limites da demanda, determinado somente pela atividade das partes - princípio da congruência ou da adstrição.

A doutrina italiana, grande referência para o direito processual brasileiro, mesmo à época de vigência do CPC de 1865 (1865-1940) foi bastante tranquila quanto à aceitação da intervenção iussu iudicis para o mero alargamento subjetivo da demanda, reservando suas resistências ao alargamento objetivo. Rapidamente, os processualistas italianos superaram a resistência quanto à inclusão de um terceiro no processo pendente inter alios, por ordem do juiz, mantendo suas divergências basicamente quanto às suas hipóteses de cabimento e sua extensão.

Ainda assim, falar em atuação do juiz no processo civil brasileiro parece ser uma afronta ao grande dogma que paira sobre a matéria. Para todas as situações em que haja

\footnotetext{
495 LÔBO DA COSTA. Obra citada. pp. 156-7.

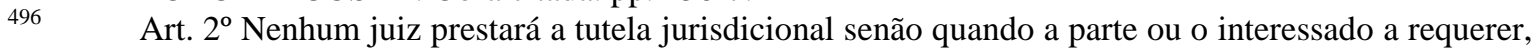
nos casos e forma legais.
} 
envolvimento do interesse público, dirão, existe o Ministério Público, com competências e poderes amplos conferidos pela Constituição ${ }^{497}$ e pelo próprio CPC $^{498}$. A defesa do interesse público compete a este ente e não ao Poder Judiciário, que deve se portar no processo com equidistância e imparcialidade.

Formou-se um método de resolução de controvérsias entre indivíduos, decorrente de lides de direito privado, que por falta de outro instrumento disponível, acabou por servir, de forma principal ou subsidiária, para conflitos de interesse público. Foi exatamente o que aconteceu com o controle judicial de políticas públicas, que pode ser exercido pela via das ações individuais ou coletivas.

497 Art. 127. O Ministério Público é instituição permanente, essencial à função jurisdicional do Estado, incumbindo-lhe a defesa da ordem jurídica, do regime democrático e dos interesses sociais e individuais indisponíveis.

Art. 129. São funções institucionais do Ministério Público:

I - promover, privativamente, a ação penal pública, na forma da lei;

II - zelar pelo efetivo respeito dos Poderes Públicos e dos serviços de relevância pública aos direitos assegurados nesta Constituição, promovendo as medidas necessárias a sua garantia;

III - promover o inquérito civil e a ação civil pública, para a proteção do patrimônio público e social, do meio ambiente e de outros interesses difusos e coletivos;

IV - promover a ação de inconstitucionalidade ou representação para fins de intervenção da União e dos Estados, nos casos previstos nesta Constituição;

$\mathrm{V}$ - defender judicialmente os direitos e interesses das populações indígenas;

VI - expedir notificações nos procedimentos administrativos de sua competência, requisitando informações e documentos para instruí-los, na forma da lei complementar respectiva;

VII - exercer o controle externo da atividade policial, na forma da lei complementar mencionada no artigo anterior;

VIII - requisitar diligências investigatórias e a instauração de inquérito policial, indicados os fundamentos jurídicos de suas manifestações processuais;

IX - exercer outras funções que lhe forem conferidas, desde que compatíveis com sua finalidade, sendo-lhe vedada a representação judicial e a consultoria jurídica de entidades públicas.

498 Art. 81. O Ministério Público exercerá o direito de ação nos casos previstos em lei, cabendo-lhe, no processo, os mesmos poderes e ônus que às partes.

Art. 82. Compete ao Ministério Público intervir:

I - nas causas em que há interesses de incapazes;

II - nas causas concernentes ao estado da pessoa, pátrio poder, tutela, curatela, interdição, casamento, declaração de ausência e disposições de última vontade;

III - nas ações que envolvam litígios coletivos pela posse da terra rural e nas demais causas em que há interesse público evidenciado pela natureza da lide ou qualidade da parte. (Redação dada pela Lei $\mathrm{n}^{\circ}$ 9.415, de 23.12.1996)

Art. 83. Intervindo como fiscal da lei, o Ministério Público:

I - terá vista dos autos depois das partes, sendo intimado de todos os atos do processo;

II - poderá juntar documentos e certidões, produzir prova em audiência e requerer medidas ou diligências necessárias ao descobrimento da verdade.

Art. 84. Quando a lei considerar obrigatória a intervenção do Ministério Público, a parte promoverlhe-á a intimação sob pena de nulidade do processo.

Art. 85. O órgão do Ministério Público será civilmente responsável quando, no exercício de suas funções, proceder com dolo ou fraude. 
As ações coletivas não dispõem de um procedimento único, com uma estrutura toda planejada para a consecução de seus fins. Apesar disso, como bem lembra Camilo Zufelato, "é fato inconteste que o Brasil possui um dos sistemas processuais mais completos e eficazes de tutela jurisdicional coletiva do mundo" ${ }^{499}$. Após a edição de numerosas leis, que versam sobre assuntos diversos, mas se comunicam por suas disposições processuais, o ordenamento processual brasileiro passou a dispor de um chamado micro ou minissistema de processos coletivos, que abrange, basicamente, as Leis de Ação Popular, de Ação Civil Pública e o Código de Defesa do Consumidor.

Além da utilização do minissistema de ações coletivas, Camilo Zufelato lembra que as ações constitucionais também podem ser utilizadas para promoção de uma política pública executada de forma insatisfatória ou não executada ${ }^{500}$. Apesar de sua utilidade, as ações coletivas não são recorrentes para atendimento da maioria das pretensões veiculadas em processos de controle de políticas públicas, quais sejam, as que pressupõem a urgência do atendimento. $\mathrm{O}$ indivíduo que tenha pressa para conseguir um determinado tratamento de saúde ou uma vaga escolar antes do início do ano letivo não pode esperar pela propositura de uma ação coletiva pelos entes legitimados - supondo que a coletividade possa precisar da mesma tutela desse indivíduo hipotético ${ }^{501}$.

Demonstrativo disso são os resultados apurados junto à justiça paulista por Fabíola Fanti, em seu trabalho de conclusão de mestrado em ciências políticas pela FFLCH-USP. De acordo com os dados coletados, $56 \%$ das ações ajuizadas contra o Município de São Paulo, no período entre outubro de 2007 e dezembro de 2008, que tinham por objeto a discussão acerca do direito à saúde com base no art. 196 da Constituição, foram ações individuais $^{502}$.

499 ZUFELATO, Camilo. Controle Judicial de Políticas Públicas mediante Ações Coletivas e Individuais. In: GRINOVER, Ada Pellegrini; WATANABE, Kazuo. 2013. p. 315.

$500 \quad$ ZUFELATO. Obra citada. p. 315.

501 "as políticas públicas devem ser enfocadas do ponto de vista de direitos transindividuais - e a consequente utilização de todo o aparato processual decorrente disso -, e nessa medida o acolhimento do pedido tutelará ao mesmo tempo todos os indivíduos que se encontram naquela situação fática ou jurídica, a depender da espécie de direito protegido. Não se pode perder de vista, contudo, que o sujeito inserido na coletividade carente de certa política pública poderá requerer a tutela da sua parcela subjetiva daquele direito coletivo, por intermédio de uma demanda individual, que trará somente a ele a proteção requerida". ZUFELATO. Obra citada. p. 327.

502 FANTI. Obra citada. A pesquisa, porque conduzida por profissional da área das ciências políticas, não leva em consideração que "o critério relevante para se classificar uma ação em individual ou coletiva é a cindibilidade ou não da decisão judicial”. ZUFELATO. Obra citada. p. 328. Apesar disso, o próprio Camilo Zufelato reconhece que "essas ações estritamente individuais têm sido utilizadas com frequência na prática 
Essas ações são manejadas com utilização do aparato disponibilizado pelo CPC. Veja-se, uma lide que envolve a efetivação de direitos fundamentais e a omissão do estado na realização de uma política pública conducente ao atingimento dos objetivos da República é resolvida com o mesmo instrumental utilizado para resolver conflitos entre vizinhos ou familiares.

O interesse existente nessas demandas é, sobretudo, público. Sob todos os prismas as demandas desse modelo não podem ser consideradas individualistas, porque mesmo o direito tutelado pelo indivíduo, de maneira solitária, tem natureza pública.

É preciso assumir, portanto, que são necessárias mudanças (de lege lata ou de lege ferenda) a fim de que se possa dar aos cidadãos as garantias adequadas à tutela de direitos previstos constitucionalmente.

A doutrina processual brasileira parece, aos poucos, abrir-se para uma atuação menos tacanha do magistrado. Fredie Didier Jr., em escrito onde questiona a existência de litisconsórcio ativo necessário, sugere uma interpretação extensiva do poder do juiz previsto no parágrafo único do art. 47 do CPC (determinação de inclusão no processo do litisconsorte necessário pelo juiz) para as situações em que for verificado litisconsórcio unitário facultativo e uma dos sujeitos da relação jurídica material, embora afetado pela decisão a ser proferida, tenha sido deixado de fora da relação processual pelas partes. Com vistas a evitar decisões conflitantes e também para resguardar o interesse do terceiro, Fredie Didier Jr. prega um retorno ao CPC de 1939 no que toca à intervenção iussu iudicis $^{503}$.

Obviamente, a defesa de um retorno ao CPC de 1939 é figura meramente retórica utilizada por Fredie Didier Jr., como forma de sinalizar a anterior existência da técnica que pretende reavivar. Isso porque, como visto anteriormente, a redação do art. 91 do CPC de 1939 era

forense, sobretudo em questões envolvendo direito à saúde, como as demandas que visam à obtenção de determinado medicamento às custas do Estado ou a realização de exames ou procedimento cirúrgico não disponibilizado pelo SUS”. ZUFELATO. Obra citada. pp. 328-9.

${ }_{503}$ DIDIER JR., Fredie. Litisconsórcio ativo necessário? http://www.frediedidier.com.br/wpcontent/uploads/2012/02/litisconsorcio-necessario-ativo.pdf 
confusa, deficiente e trouxe mais problemas que soluções ao ordenamento jurídico brasileiro.

O que interessa nessa posição, porém, é demonstrar que a intervenção por ordem do juiz é aceita até mesmo para relações entre particulares - como nos exemplos citados pelo autor $^{504}$ - quando na defesa de interesses absolutamente privados. Ora, se é verdade que o processo civil recebe cada vez mais influência do direito constitucional e se abre às demandas oriundas dos demais ramos de direito material, é impossível objetar-se à utilização dessa técnica para processos de interesse público.

A necessidade de se promover uma alteração no procedimento utilizado para o controle judicial de políticas públicas deriva dos efeitos nocivos que têm sido gerados pelas decisões proferidas pelos tribunais brasileiros ${ }^{505}$. Afinal, a quem afeta a decisão proferida nesse tipo de demanda?

A necessidade de submissão das partes e seus argumentos ao contraditório afasta da autoridade da coisa julgada aqueles que não participaram do processo. Logo, somente o ente federado que tiver sido parte estará obrigado a cumprir o comando decisório expedido. Independentemente de ter responsabilidade sobre a execução da política pública, ele deverá absorver os ônus dessa decisão para si, já que sequer possui direito de regresso contra o ente considerado responsável pelo ordenamento jurídico. Esse é o posicionamento da jurisprudência brasileira. Em precedente esclarecedor sobre o tema, o STJ, fazendo remissão à jurisprudência do STF, expôs o seguinte:

Não é cabível o chamamento ao processo da União Federal na hipótese de ação
de fornecimento de medicamentos movida em face do estado de Santa Catarina,
pois, conforme externado pelo STF no julgamento de recurso extraordinário,
trata-se de medida inútil e protelatória, considerando que o objetivo do
chamamento ao processo é garantir ao devedor solidário o direito de regresso
caso seja perdedor da demanda, sendo que, no caso, mesmo que a União integre
o feito em comunhão com o Estado, caso saiam perdedores na demanda, o

504 "Além disso, também serviria para cientificar cônjuge/companheiro em demandas reais imobiliárias propostas pelo outro consorte". DIDIER JR., Fredie. Litisconsórcio ativo necessário? ${ }_{505}$ ttp://www.frediedidier.com.br/wp-content/uploads/2012/02/litisconsorcio-necessario-ativo.pdf

505 A construção de procedimentos está intimamente relacionada, ainda, com a produção de coisa julgada material: a) seja na medida em que esta depende da existência de cognição judicial exauriente; b) seja porque os procedimentos são elaborados a partir da conjugação das técnicas de cognição. DIDIER JR. Obra citada. p. 6. 
Estado de Santa Catarina arcará sozinho com o ônus do fornecimento do medicamento requerido, porque essa foi a escolha do autor da ação ${ }^{506}$.

Vê-se, portanto, que aos entes federados não é dada qualquer saída para enfrentarem os problemas que são criados pela jurisprudência pátria. É de se ponderar, ainda, como já dito anteriormente, que a maioria das ações que buscam o controle de alguma política social é ajuizada de maneira individual, de forma que o mesmo cidadão pode pedir medicamentos aos três entes federados - e consegui-los -, sobrando inclusive para revenda. Pode-se argumentar que esse seja um pequeno defeito que não invalida todo o sistema, mas a questão é que o processo de controle de políticas públicas pode conseguir proporcionar o bem pleiteado pelo cidadão e, ao mesmo tempo, impor o menor sacrifício possível ao erário, mediante a obediência das regras distribuidoras de responsabilidade.

Mas, para além disso, a soma de ações individuais e a permissão de demandar em face de qualquer dos entes federados gera situação de descontrole, que destrói qualquer chance de mapeamento e desenho de uma perspectiva global acerca do problema da saúde ou da educação $^{507}$.

Em virtude dos problemas narrados, a proposta dessa tese é possibilitar ao juiz a correção do polo passivo das ações que visem ao controle de políticas públicas sociais. Ao receber a petição inicial, o juiz, após identificar as exigências dos arts. 282, 283 e 295 do CPC, determinará a citação do réu indicado e apreciará, se houver, o pedido de tutela de urgência.

Verificando o juiz que o ente indicado pelo autor não detém responsabilidade pela execução direta da política pública questionada, ele deverá, ainda, determinar a citação do ente supostamente responsável, incluindo-o de ofício no polo passivo da demanda. Essa medida é passível de imediata aplicação, como já dito, com base no princípio da adaptabilidade e em respeito aos direitos fundamentais ao aos princípios constitucionais da

506 BRASIL. Superior Tribunal de Justiça. AgRg no AREsp 64.419/SC, Rel. Ministro TEORI ALBINO ZAVASCKI, PRIMEIRA TURMA, julgado em 22/11/2011, DJe 30/11/2011.

507 "Nesse sentido, as ações individuais não teriam o condão de propiciar o planejamento próprio de políticas públicas, pois se estaria julgando uma situação deslocada da perspectiva global do fenômeno, podendo inclusive, v.g., conceder medicamento para certo beneficiário que por suas condições econômicas nunca foi usuário do SUS, comprometendo em última análise o orçamento para a efetiva construção de uma política de saúde para usuários do SUS”. ZUFELATO. Obra citada. p. 330. 
eficiência e economicidade, que se sobrepõem ao princípio da demanda, que sequer encontra sede constitucional, tendo até mesmo sua natureza de princípio questionada.

A única fragilidade da adoção imediata da técnica é a inexistência de mecanismo de coerção dirigido à parte. No direito italiano, existe a previsão de cancelamento do processo, conferindo à decisão do juiz maior poder de convencimento. Já o direito francês, não dispõe de qualquer medida dessa natureza, tendo a jurisprudência dotado essa decisão de força coercitiva. Porém, como a jurisprudência brasileira segue direção diametralmente oposta, acredita-se que seria necessária a edição de lei com expressa adoção de medida coercitiva, para os casos em que o juiz determinar a intervenção de um terceiro na demanda e a parte o descumprir. Logicamente, a imposição de sanção somente é aceitável após a submissão da decisão ao contraditório, para que as partes possam controlar a adaptabilidade do procedimento.

Essa decisão seria admitida somente em primeiro grau de jurisdição, uma vez que a inclusão de uma parte após a prolação de sentença prejudica substancialmente sua defesa, em decorrência da supressão de instância.

Quando o próprio juiz tiver dúvidas acerca da responsabilidade dos entes pela execução da política pública questionada, ele determinará a inclusão do terceiro na demanda e procederá tal qual determina o art. 898 do CPC, para os casos de dúvida em relação ao legítimo credor: determinará a imediata execução da política pública, liberando o cidadão do processo, que terá prosseguimento somente entre os entes litigantes, como forma de se apurar o verdadeiro responsável pela execução da política pública determinada.

Ao juiz competirá a escolha do ente que atenderá imediatamente ao pedido do autor, com base em juízo de verossimilhança devidamente fundamentado. Caso, ao final do processo, esse ente não seja o responsável, receberá do sucumbente os valores dispendidos para cumprimento da ordem judicial.

Uma vez inserido o terceiro no processo, ele adquire a qualidade de parte, não sendo mero assistente, podendo, além de dispor de todos os poderes conferidos às partes, ser submetido à autoridade da coisa julgada formada na demanda. Merece destaque o fato de que, nos casos apresentados, o juiz apenas controla os limites subjetivos da demanda, não havendo 
ampliação objetiva. O juiz permanece balizado pelos pedidos exatamente como formulados pelo autor, havendo somente correção do polo passivo com inclusão de outra parte, que só pode ingressar na lide em razão de sua ligação com o objeto da demanda.

Por fim, destaca-se que a intervenção iussu iudicis, ao contrário do que se passa nos ordenamentos italiano e francês, não ficaria relegada ao arbítrio do juiz, decorrente de seu juízo de oportunidade, mas decorreria diretamente do regime especial conferido aos direitos fundamentais. 


\section{CONCLUSÃO GERAL}

Como visto, a Constituição não impõe solidariedade obrigacional aos entes federados em relação à execução das políticas públicas, tendo deixado a cargo de leis complementares a distribuição das competências. As competências delineadas não têm sido observadas pelos tribunais brasileiros, especialmente no que tange ao direito à saúde. As decisões proferidas vêm trazendo incontáveis prejuízos aos entes federados, com sobreposição de competência e replicação de estruturas físicas e administrativas.

Falar em possibilidade de ajuda e colaboração não é afirmar a existência de responsabilidades. Afinal, cooperar pressupõe auxiliar alguém no cumprimento de suas tarefas; a execução de responsabilidades que são próprias não passa de cumprimento de dever ou ônus.

A Constituição brasileira, ao prever em seus artigos 6 6 23,196 e 205 uma atuação conjunta dos entes na prestação dos direitos de saúde e educação não impôs obrigações equivalentes a todos os entes, até porque essa medida desrespeita o fundamento primordial do federalismo e, com maior razão, do federalismo fiscal. Cada ente deve receber cota de responsabilidade compatível com seu tamanho, sua população, sua abrangência e, especialmente, suas rendas.

A imposição indiscriminada de obrigações solidárias aos entes federados têm trazido dificuldades às contas públicas, desperdício de renda e aumento declarado dos níveis de corrupção. Fora isso, no longo prazo, esse entendimento traz prejuízos que se traduzem pela falta correta de planejamento das políticas e das peças orçamentárias, que precisam de constantes remanejamentos e, por vezes, sofrem até intervenção direta pelo Judiciário que, ao contrário do Administrador, não se submete aos controles interno e externo de contas.

A jurisprudência dos tribunais nacionais tem ignorado essas divisões, defendendo que dos dispositivos constitucionais decorre um comando de solidariedade entre os três entes federados que os obriga a prestar, independentemente do pedido formulado, a parcela da política pública considerada omissa ou inadequada por um cidadão litigante. $\mathrm{O}$ argumento unânime utilizado pelos tribunais é, além de metajurídico, equivocado. Por compaixão, verificou-se a formação da chamada jurisprudência de misericórdia, que 
independentemente do argumento apresentado pelo ente federado inserido no polo passivo de um processo de controle de política pública, diz que perante o direito à saúde, argumentos de ordem financeira são secundários e podem, por essa razão, ser desconsiderados.

Ficou esclarecido, ainda, que os prejuízos impostos à estrutura financeira dos entes federados não geram reflexos positivos na execução das políticas sociais, especialmente nas de saúde. $\mathrm{O}$ atendimento pela via judicial é pontual, casuístico e não importa, salvo marcadas exceções, em melhorias para a coletividade.

Ainda sobre o tema, ficou claro o fato de que a União é a maior arrecadadora de tributos e que, portanto, dispõe de mais renda para planejamento e execução das políticas públicas. No entanto, os estudos realizados na área do federalismo fiscal demonstram que a centralização dos serviços públicos não é a melhor opção, devendo ser estipuladas responsabilidades de acordo com a política pública desejada e os fins esperados. Essa dinâmica induz a construção de mecanismos de distribuição de verbas entre os entes, como forma de permitir que todos possam ter disponibilidade de caixa para execução das políticas públicas que sejam postas sob sua responsabilidade.

No Brasil, cuja estrutura é de um federalismo cooperativo regido pelo princípio da lealdade federativa, a Constituição fez previsões de despesas obrigatórias para os ramos mais sensíveis dos direitos sociais: saúde e educação. Nesses casos, além da criação de fundos financeiros que suportam o custeio das políticas sociais, ainda é garantido aos entes subnacionais transferências obrigatórias pela União, isolando desses direitos qualquer forma de clientelismo partidário, tratado no texto pelo termo utilizado pelas ciências políticas pork barrel.

Dentre os critérios previstos para transferência de fundos, há a recomposição financeira dos entes que tenham gastos relevantes com a execução de determinada política sociais, o que demonstra a necessidade de focalizar as responsabilidades, como forma de garantir aos entes o recebimento permanente de verbas, garantindo a projeção de uma política de longo prazo e não somente o cumprimento ocasional de uma decisão emanada pelo Poder Judiciário. 
Assim, cada ente é responsável, na medida de suas possibilidades, pela execução de parte da política pública social constitucionalmente prevista. É o caso da saúde. Quando a Constituição determina que todos os entes participem e financiem o SUS, ela não os obriga a executar todo e qualquer serviço inerente à efetivação do direito à saúde. Do contrário, haveria - como tem havido - uma superposição perniciosa ao sistema, que somente gera aumento de custos e maior facilidade de desperdício e desvios de verba pública. Ciente dessas decorrências, o próprio constitutinte previu, no parágrafo único do art. 23, a necessidade de regulamentação e definição das responsabilidades de cada um dos entes federados.

Essa estrutura é facilitada, pois, uma vez que todos os entes são considerados responsáveis pela execução de todas as políticas sociais, qualquer um que seja indicado para ocupar o polo passivo de uma demanda dessa natureza é considerado legitimado, sem maiores problemas processuais a serem resolvidos.

Do contrário, a atribuição de responsabilidade a cada um dos entes gera dificuldades práticas no âmbito processual. Quando um ente não responsável é demandado judicialmente, o juiz não pode, com as técnicas disponíveis no CPC, corrigir o polo passivo da demanda, restando-lhe, somente, a extinção do processo sem resolução do mérito. Acontece que essa medida não atende à estrutura dos direitos fundamentais, que exigem efetivação imediata e não podem ser submetidos a percalços decorrentes do método de resolução de controvérsias.

Por essa razão, visando a garantir a imediata efetivação dos direitos fundamentais, porém de forma mais eficiente e econômica, essa tese reaviva (não sem alterações formais) o instituto da intervenção iussu iudicis, que autoriza ao juiz o controle da composição subjetiva da demanda em decorrência dos direitos veiculados no processo.

A possibilidade de controlar o polo passivo da demanda e promover a condenação do ente que seja o responsável pela execução direta da política pública social questionada em juízo contribuirá para diminuir sensivelmente o impacto das decisões judiciais sobre os orçamentos dos entes federados, que não mais precisarão saldar, com recursos próprios, obrigações de outros entes. A medida reduz - senão extingue - a sobreposição de 
competências e a consequente multiplicação de estruturas e facilita o controle pelos órgãos de contas e pelo Ministério Público.

Tendo descartado a possibilidade de ampliação objetiva do processo e de atuação de ofício baseada em mero juízo de conveniência, a tese demonstra a necessidade de correção do instrumento utilizado para os processos que tenham por objeto o controle judicial de políticas públicas. Essa correção deveria ser promovida pela via legislativa, razão pela qual sugere-se a inserção da técnica na redação do Anteprojeto de Controle de Políticas Públicas elaborado pelo CEBEPEJ ${ }^{508}$. No entanto, com apoio do princípio da adaptabilidade e por força dos comandos constitucionais decorrentes dos direitos fundamentais e dos princípios da efetividade e economia, sugere-se a possibilidade de utilização imediata da técnica como forma de evitar maiores prejuízos à Administração Pública.

\footnotetext{
508 É sugerida a inclusão do parágrafo primeiro no art. 13 do Anteprojeto, que passaria a exibir a seguinte redação:

Art. 13. Não havendo acordo, o juiz examinará, no juízo de admissibilidade, a razoabilidade do pedido e a irrazoabilidade da atuação da Administração, podendo extinguir o processo, com resolução do mérito, ou determinar a citação do representante judicial da autoridade competente, para responder.

$\S 1^{\circ}$. O juiz poderá, ainda, determinar de ofício a citação do representante judicial de outro órgão ou ente federado quando identificar sua responsabilidade em relação à política pública questionada. redação:

Sugere-se, ainda, a inclusão dos parágrafos primeiro e segundo no art. 14, que exibiriam a seguinte

Art. 14. Determinada a citação, a autoridade responsável pela política pública continuará vinculada ao processo, inclusive para os fins do disposto no artigo 18 .

$\S 1^{\circ}$. Havendo pluralidade de partes no polo passivo, o juiz poderá determinar, a qualquer momento, a exclusão da autoridade cuja responsabilidade pela política pública questionada seja afastada mediante elementos probatórios ou reconhecimento do pedido do autor por alguma outra.

$\S 2^{\circ}$. Quando o conhecimento da responsabilidade de algum dos entes integrantes do polo passivo da demanda carecer de atividade cognitiva mais aprofundada, o juiz poderá dividir o procedimento em duas etapas, a exemplo da previsão contida no art. 898, última parte do $\mathrm{CPC}$, determinando o imediato cumprimento do comando decisório por algum dos entes e, depois de satisfeito o pedido formulado, o processo prosseguiria somente entre as autoridades incluídas no polo passivo. Reconhecida a responsabilidade daquele que foi compelido ao cumprimento da decisão, o processo deve ser extinto imediatamente; do contrário, o juiz declarará o crédito em favor do ente que arcou indevidamente com os custos, abrindo-se a fase de cumprimento de sentença, na forma prevista pelos art. 475-I e ss. do CPC.
} 


\section{CONCLUSÕES ESPECÍFICAS}

1. A construção do estado brasileiro obedece a um modelo de federalismo denominado cooperativo, que autoriza a interação permanente e recíproca entre os entes federados, conferindo maior dinâmica no desempenho de suas responsabilidades, mediante ajuda mútua.

2. A viga mestra desse esquema federativo é o princípio da lealdade federativa, que se desdobra em solidariedade e fidelidade.

3. Essa solidariedade é que permite a atuação conjunta de todos os entes, ao contrário do que se passa em um federalismo dual, onde a conjunção de esforços é medida excepcional.

4. A opção por essa forma de federalismo ajuda a que as estruturas de efetivação dos direitos fundamentais - especialmente, os sociais - saiam fortalecidas e reforçadas, pois contam com a contribuição de todos os entes federados.

5. O federalismo fiscal é ferramenta indispensável na compreensão dos processos de arrecadação e gastos públicos e permite ao legislador verificar a capacidade de cada ente de absorver uma responsabilidade.

6. A observância das opções formuladas pelo constituinte e pelo legislador acerca da distribuição de competências entre os entes federados para execução de políticas públicas, além de otimizar o gasto público, ainda permite ganho de eficiência e accountability, com garantia de aplicação dos princípios da eficiência e economicidade.

7. No caso da saúde, essa definição está prevista nas Leis nº 8080 e 8142/90, que repassam às portarias do Ministério da Saúde a competência para delineamento mais preciso dessas atribuições.

8. O direito à educação tem melhor regulamentação constitucional após a edição da Emenda Constitucional n ${ }^{\circ}$ 14/1996 e infraconstitucional após a edição de Lei de Diretrizes e Bases (LDB). 
9. O processo de controle de políticas públicas não dispõe das técnicas mais adequadas para resolver questões relativas à natureza dos direitos nele veiculados, já que o procedimento é tomado de empréstimo, não havendo um adequado para esse tipo de demanda.

10. O CEBEPEJ formulou um anteprojeto de lei para construção de um procedimento próprio ao controle judicial de políticas públicas, que em grande medida respeita e atende os direitos fundamentais que precisam de maior concretização.

11. O Anteprojeto, porém, não contempla a concessão de poderes ao Juiz para que possa controlar o polo passivo da demanda, de forma a permitir a condução do processo mediante a inclusão do responsável direto pela execução da política pública na relação jurídica processual desenvolvida sob o signo do contraditório.

12. O princípio dispositivo, há tempos, já vem sofrendo mitigação por parte da doutrina e da jurisprudência, tendo deixado de ser entendido como livre disposição das partes sobre o processo, passando a autorizar maior atuação do juiz em razão do interesse da justiça na correção da decisão final.

13. O princípio da demanda, contudo permanece, imaculado, sendo um dogma do processo civil. Esse princípio foi pensado, todavia, para proteção de direitos privados e disponíveis, não atendendo com plenitude às peculiaridades dos direitos sobre os quais há notório interesse público.

14. Para permitir que o ente federado diretamente responsável pela execução de uma determinada política pública seja inserido em uma demanda inter alios, em que esta política esteja sendo exigida de outro ente, seria necessária a utilização do instituto da intervenção iussu iudicis, não previsto no Código de Processo Civil de 1973.

15. A adoção da técnica no ordenamento jurídico brasileiro seria possível, de acordo com o princípio da adaptabilidade e em homenagem aos direitos fundamentais e aos princípios constitucionais da eficiência e economicidade, além não violar nenhum princípio 
processual. Portanto, descarta-se a intervenção de ofício baseada em mero juízo de conveniência do juiz.

16. O terceiro ingressaria como parte no processo de controle de políticas públicas e teria os mesmos ônus e poderes disponíveis às demais partes do processo, podendo sofrer a condenação decorrente da decisão final - que é, aliás, a intenção maior no uso da técnica.

17. No processo que houver pluralidade de partes no polo passivo, o juiz poderá determinar, a qualquer momento, a exclusão da autoridade cuja responsabilidade pela política pública questionada seja afastada mediante elementos probatórios ou reconhecimento do pedido do autor por alguma outra.

17. Quando houver dúvida até mesmo pelo magistrado de qual ente seja diretamente responsável pela execução da política pública questionada, ele poderá manter no polo passivo dois ou mais entes e adotar o procedimento previsto no CPC para a consignação em pagamento, determinando o imediato atendimento do pleito formulado pelo cidadão e após, isso, conduzindo o processo somente com a presença dos entes públicos, numa etapa de conhecimento que permita verificar a quem competiria a execução da política pública exigida. 


\section{REFERÊNCIAS}

ABRAMOVICH, Victor; COURTIS, Christian. Los derechos sociales como derechos exigibiles. Madrid: Trotta. 2002.

ABRÚCIO, Fernando. Descentralização - pacto federativo. Cadernos ENAP. nº 1, 1993.

ALMEIDA, Fernanda Dias Menezes de. Competências na Constituição de 1988. 5. ed. São Paulo: Atlas. 2010. p. 117.

AFONSO DA SILVA, Luís Virgílio. Federalismo e articulação de competências no Brasil. In: Guy Peters; Jon Pierre. [org.]. Administração pública: coletânea. Brasília/São Paulo: v. 1. ENAP/UNESP, 2010.

ARAGÃO, Alexandre dos Santos. Interpretação consequencialista e análise econômica do Direito Público à luz dos princípios constitucionais da eficiência e da economicidade. In: RAMALHO, Pedro Ivo Sebba [org.]. Regulação e Agências Reguladoras. Governança e Análise de Impacto Regulatório. 1. ed. Brasília, 2009.

ARAÚJO, Gilda Cardoso de. Federalismo e direito à educação no Brasil: entre a autonomia e a igualdade de oportunidades. Disponível em: https://www.google.com.br/url?sa=t\&rct=j\&q=\&esrc=s\&source=web\&cd=1\&ved=0CC0Q FjAA\&url=http\%3A\%2F\%2F26reuniao.anped.org.br\%2Fposteres\%2Fgildacardosoaraujo. rtf\&ei=wLbUUo2hFpTqkAfqpoG4DA\&usg=AFQjCNECu7kj8YggfIwKHsvKlLqXkbN7 mA\&sig2=gCRVsrxqcnHhaSyCCWC-Gw.

ARDIZZI, Alberto. L'intervento iussu iudicis nel processo amministrativo. In: Rivista amministrativa della Repubblica italiana. vol. 159. Fascicolo: 3/4. Parte: 2. 2008.

ARENHART, Sérgio Cruz. Reflexões sobre o princípio da demanda. Disponível em: https://ufpr.academia.edu/SergioCruzArenhart.

ARRETCHE, Marta. Continuidades e descontinuidades da federação brasileira: de como 1988 facilitou 1995. In: Dados. Rio de Janeiro, vol. 52, n², 2009. pp. 377 a 423.

Democracia, federalismo e centralização no Brasil. Rio de Janeiro: FGV; Fiocruz, 2012. p. 16.

. Federalismo e Políticas Sociais no Brasil. In: São Paulo em perspectiva, 18(2): 17-26, 2004.

ASSONI FILHO, Sérgio. ASSONI FILHO, Sérgio. Controle de Constitucionalidade da Lei Orçamentária. In: CONTI, José Maurício; SCAFF, Fernando Facury. [org.] Orçamentos Públicos e Direito Financeiro. São Paulo: RT, 2011. 
BADARÓ, Gustavo. Direito a um julgamento por juiz imparcial: como assegurar a imparcialidade objetiva do juiz nos sistemas em que não há a função do juiz de garantias. In: BONATO, Gilson. [org]). Processo Penal, Constituição e Crítica. Estudos em Homenagem ao Prof. Dr. Jacinto Nelson de Miranda Coutinho. 1. ed.Rio de Janeiro: Lumen Juris, 2011.

BARACHO, José Alfredo de Oliveira. Direito Processual Constitucional. Belo Horizonte: Forum, 2006.

BARRADAS BARATA, Luiz Roberto; MENDES, José Dínio Vaz. Uma proposta de política de assistência farmacêutica para o SUS. In: BLIACHERIENE, Ana Carla; SANTOS, José Sebastião [org.] Direito à vida e à saúde. Impactos orçamentário e judicial. São Paulo: Atlas, 2010.

BERMUDES, Sérgio. Introdução ao processo civil. Rio de Janeiro: Forense, 1995.

BEDAQUE, José Roberto dos Santos. Efetividade do processo e técnica processual. São Paulo: Malheiros, 2006. P. 278.

Direito e Processo. Influência do direito material sobre o processo.

4. ed. São Paulo: Malheiros, 2006b.

Poderes Instrutórios do Juiz. 4. ed. rev. atual. amp. São Paulo: RT, 2009.

BERCOVICI, Gilberto. Dilemas do Estado Federal Brasileiro. Porto Alegre: Livraria do Advogado. 2004.

Série Pensando o Direito. n. 13/2009. p. 13. Disponível em:

http://participacao.mj.gov.br/pensandoodireito/wp-

content/uploads/2012/11/13Pensando_Direito.pdf. 90.pdf)

BERIZONCE, Roberto Omar. Los conflitos de interés público. In: Revista Peruana de Derecho Processal. N. 17. Ano XVIII. Lima: Editorial Comunitas, 2013.

Activismo Judicial y Participación en la Construcción de las

Políticas Públicas. Disponível em: http:/

/www.civilprocedurereview.com/busca/baixa_arquivo.php?id=24\&embedded=true.

BIELSA, Rafael. Princípios de régimen municipal. Buenos Aires: Abeledo-Perrot, 1962.

BINENBOJN, Gustavo. Uma teoria do direito administrativo... Rio de Janeiro: Renovar, 2006.

BLIACHERIENE, Ana Carla; MENDES, Guilherme Adolfo dos Santos. Lei de Responsabilidade Fiscal e os limites da vinculação e da discricionariedade na execução da dotação orçamentária: o impacto das liminares judiciais relativas à saúde para o orçamento 
dos municípios. In: BLIACHERIENE, Ana Carla; SANTOS, José Sebastião [org.] Direito à vida e à saúde. Impactos orçamentário e judicial. São Paulo: Atlas, 2010.

BÖCKENFÖRDE, Ernst Wolfgang. Estudios sobre el Estado de Derecho y la democracia. Madrid: Editorial Trotta, 2000.

BONAVIDES, Paulo. Curso de Direito Constitucional. São Paulo: Saraiva, 1992.

BRASIL. Supremo Tribunal Federal. RE 566.509, Relator(a): Min. AYRES BRITTO, julgado em 11/10/2011, publicado em DJe-201 DIVULG 18/10/2011 PUBLIC 19/10/2011. BRASIL. Supremo Tribunal Federal. ADI n⿳ 612-RJ. Rel. Min. Celso de Mello. DJ 19.09.1997.

BRASIL. Supremo Tribunal Federal. RE 566471 RG, Relator(a): Min. MARCO AURÉLIO, julgado em 15/11/2007, DJe-157 DIVULG 06-12-2007 PUBLIC 07-12-2007 DJ 07-12-2007 PP-00016 EMENT VOL-02302-08 PP-01685.

BRASIL. Superior Tribunal de Justiça. AgRg no AREsp 40027/SC, Relatoria Ministro Humberto Martins; AgRg no AREsp 28136/SC, Relatoria Ministro Herman Benjamin BRASIL. Superior Tribunal de Justiça. REsp 513660/RS, Rel. Ministro LUIZ FUX, PRIMEIRA TURMA, julgado em 20/11/2003, DJ 19/12/2003, p. 346

BRASIL. Superior Tribunal de Justiça. REsp 717800/RS, Rel. Ministra DENISE ARRUDA, PRIMEIRA TURMA, julgado em 25/03/2008, DJe 30/06/2008.

BRASIL. Superior Tribunal de Justiça. AgRg no REsp 102213/SC, Relatoria Ministro Humberto Martins

BRASIL. Superior Tribunal de Justiça. MS 10724/DF, Rel. Ministra ELIANA CALMON, Rel. p/ Acórdão Ministro LUIZ FUX, PRIMEIRA SEÇÃO, julgado em 26/04/2006, DJ 12/06/2006, p. 408.

BRASIL. Superior Tribunal de Justiça. AgRg no REsp 866393/RJ, Rel. Ministro LUIZ FUX, PRIMEIRA TURMA, julgado em 03/04/2008, DJe 24/04/2008.

BRASIL. Superior Tribunal de Justiça. AgRg no Ag 879975/RS, Relatoria Ministro José Delgado; REsp 873196/RS, Relatoria Ministro Teori Albino Zavascki.

BRASIL. Supremo Tribunal Federal. RE 605533 RG, Relator(a): Min. MARCO AURÉLIO, julgado em 01/04/2010, DJe-076 DIVULG 29-04-2010 PUBLIC 30-04-2010 EMENT VOL-02399-09 PP-02040 LEXSTF v. 32, n. 377, 2010, p. 243-246.

BRASIL. Supremo Tribunal Federal. ARE 639337 AgR, Relator(a): Min. CELSO DE MELLO, Segunda Turma, julgado em 23/08/2011, DJe-177 DIVULG 14-09-2011 PUBLIC 15-09-2011 EMENT VOL-02587-01 PP-00125. 
BRASIL. Supremo Tribunal Federal. RE 410715 AgR, Relator(a): Min. CELSO DE MELLO, Segunda Turma, julgado em 22/11/2005, DJ 03-02-2006 PP-00076 EMENT VOL-02219-08 PP-01529 RTJ VOL-00199-03 PP-01219 RIP v. 7, n. 35, 2006, p. 291-300 RMP n. 32, 2009, p. 279-290.

BRASIL. Superior Tribunal de Justiça. AgRg no REsp 1281020/DF, Rel. Ministro HERMAN BENJAMIN, SEGUNDA TURMA, julgado em 23/10/2012, DJe 31/10/2012. BRASIL. Superior Tribunal de Justiça. AgRg no REsp 1076592/PE, Rel. Ministro CESAR ASFOR ROCHA, SEGUNDA TURMA, julgado em 29/05/2012, DJe 13/06/2012. BRASIL. Superior Tribunal de Justiça. REsp 840.912/RS, Primeira Turma, julgado em 15.2.2007, DJ 23.4.2007)"'.

BRASIL. Superior Tribunal de Justiça. AgRg no REsp 935.083/RS, Rel. Ministro HUMBERTO MARTINS, SEGUNDA TURMA, julgado em 02/08/2007, DJ 15/08/2007, p. 268.

BRASIL. Supremo Tribunal Federal. RE 367.432-AgR/PR, Rel. Min. EROS GRAU. BRASIL. Supremo Tribunal Federal. RE 543.397/PR, Rel. Min. EROS GRAU.

BRASIL.. Supremo Tribunal Federal. RE 556.556, Relator(a): Min. ELLEN GRACIE, julgado em 03/02/2011, publicado em DJe-031 DIVULG 15/02/2011 PUBLIC 16/02/2011. BRASIL.. Supremo Tribunal Federal. RE 367.432 AgR, Relator(a): Min. EROS GRAU, Segunda Turma, julgado em 20/04/2010, DJe-086 DIVULG 13-05-2010 PUBLIC 14-052010 EMENT VOL-02401-04 PP-00750.

BRASIL.. Supremo Tribunal Federal. RE 543.397, Relator(a): Min. EROS GRAU, julgado em 07/12/2009, publicado em DJe-022 DIVULG 04/02/2010 PUBLIC 05/02/2010. BRASIL.. Supremo Tribunal Federal. RE 488.208, Relator(a): Min. CELSO DE MELLO, julgado em 01/07/2013, publicado em DJe-150 DIVULG 02/08/2013 PUBLIC 05/08/2013. BRASIL. Superior Tribunal de Justiça. REsp 1069810/RS, Rel. Ministro NAPOLEÃO NUNES MAIA FILHO, PRIMEIRA SEÇÃO, julgado em 23/10/2013, DJe 06/11/2013.

BRASIL. Superior Tribunal de Justiça. AgRg no AREsp 64.419/SC, Rel. Ministro TEORI ALBINO ZAVASCKI, PRIMEIRA TURMA, julgado em 22/11/2011, DJe 30/11/2011.

BRASIL. Constituição da República Federativa do Brasil. Disponível em: http://www.planalto.gov.br/ccivil_03/constituicao/constituicao.htm.

BRASIL. Ministério da Saúde. Secretaria de Gestão Estratégica e Participativa. A construção do SUS: histórias da Reforma Sanitária e do processo participativo. Brasília: Ministério da Saúde, 2006.

BRASIL JR., Samuel Meira. Justiça, Direito e Processo... São Paulo: Atlas, 2007. 
BUENO, Cássio Scarpinella. Poder Público em Juízo. 5. ed. São Paulo: Saraiva, 2009. Processo civil de interesse público: uma proposta de sistematização. In: SAlleS, Carlos Alberto de. Processo Civil e Interesse Público... São Paulo: RT, 2003.p. 25.

BÜLOW, Oskar von. La teoría de las excepciones procesales y los presupuestos procesales. Buenos Aires: EJEA, 1964.

CADIET, Loïc. Théorie Générale du Procès. Paris: Presses Universitaires de France, 2010. CANELA JR, Osvaldo. Controle Judicial de Políticas Públicas. São Paulo: Saraiva, 2011..

CARVALHO, André Castro. Mecanismos para a otimização do federalismo fiscal brasileiro. In: CONTI, José Maurício et alli. [org.] Federalismo Fiscal. Questões Contemporâneas. Florianópolis: Conceito Editorial, 2010.

. Vinculação de Receitas Públicas. São Paulo: Quartier Latin, $2010 b$.

CARNEIRO, Athos Gusmão. Intervenção de Terceiros. São Paulo: Saraiva, 2006. CARNELUTTI, Francesco. Lezioni di diritto processuale civile. vol IV. Padova: Univ., 1926.

CERVONE DE OLIVEIRA, Swarai. Poderes do juiz nas ações coletivas. São Paulo: Atlas, 2009.

CHIOVENDA, Giuseppe. Principii di Diritto Processuale Civile. 3. Ed. Napoli, 1923.

Principii di diritto processuale civile. Napoli: Jovene, 1965.

Istituzioni di Diritto Processuali Civile. II. 2. ed. Napoli: Jovene,

1936. p.311.

. "Dell'azione nascente dal contrato preliminare" In: Saggi di diritto

processuale civile. v. 1.Milano: Giuffrè, 1993.

CHRISTOPOUlOS, Basile. Despesa Pública. Estrutura, função e controle judicial. Maceió: UFAL. 2011.

COLOMBIA. Corte Suprema de Justicia. Sentencia SU 559-97. Disponível em: http://www.corteconstitucional.gov.co/relatoria/1997/SU559-97.htm.

COLOMBIA. Corte Suprema de Justicia. Sentencia T025/04. Disponível em: http:/ /www.corteconstitucional.gov.co/relatoria/2004/t-025-04.htm.

COMOGLIO, Luigi Paolo; FERRI, Corrado; TARUFFO, Michele. Lezioni sul processo civile. 2. Ed. Bologna: Mulino, 1998. 
CONTI, José Maurício. Considerações sobre o federalismo fiscal brasileiro em uma perspectiva comparada. In: CONTI, José Maurício et alli. [org.] Federalismo Fiscal. Questões Contemporâneas. Florianópolis: Conceito Editorial, 2010.

- Saúde não precisa só de dinheiro, mas de boa gestão. http://www.conjur.com.br/2013-out-22/contas-vista-saude-nao-dinheiro-boa-gestao.

CONSTANTINO, Giogio. Intervento del processo: diritto processuale civile. In: Enciclopedia giuridica. Roma: Instituto della Enciclopedia Italiana, 2007. 9p. v. 19.

CORREIA, Marcus Orione Gonçalves. Interpretação dos direitos fundamentais sociais, solidariedade e consciência de classe. In: CANOTILHO, J.J. Gomes. et alli [coord.] Direitos Fundamentais Sociais. São Paulo: Saraiva, 2010.

CORTI, Horacio Guillermo. Derecho Constitucional Presupuestario. Buenos Aires: AbeledoPerrot, 2011.

COSTA, Sergio. L'intervento in causa. Torino, 1953.

COUTINHO, Jacinto Nelson de Miranda. O novo papel do juiz no processo penal. In: COUTINHO, Jacinto Nelson de Miranda [coord.]. Crítica à Teoria Geral do Direito Processual Penal. Rio de Janeiro-São Paulo: Editora Renovar, 2001.

CYRILlO, Denise C.; CAMPINO, Antônio Carlos C. Gastos com a saúde e a questão da judicialização da saúde. In: BLIACHERIENE, Ana Carla; SANTOS, José Sebastião [org.] Direito à vida e à saúde. Impactos orçamentário e judicial. São Paulo: Atlas, 2010.

DIDIER JR., Fredie. Sobre dois importantes, e esquecidos, princípios do processo: adequação e adaptabilidade do procedimento. In: Revista Gênesis de Direito Processual Civil. Curitiba, n. 21, p. 530-541, jul./set. 2001.

\section{Litisconsórcio}

ativo

necessário?

http://www.frediedidier.com.br/wp-content/uploads/2012/02/litisconsorcio-necessarioativo.pdf

DINAMARCO, Cândido Rangel. Instituições de Direito Processual Civil. vol. I. 6. ed. rev. atual. São Paulo: Malheiros, 2009.

Instituições de Direito Processual Civil. vol. II. 6. ed. rev. atual.

São Paulo: Malheiros, 2009.

Nova era do processo civil. São Paulo: Malheiros, 2003.

A instrumentalidade do processo. 11. ed. São Paulo: Malheiros, 2003. 
. Escopos políticos do processo. In: GRINOVER, Ada Pellegrini;

DINAMARCO, Cândido Rangel; WATANABE, Kazuo. [coord.] Participação e Processo. São Paulo: RT, 1988.

ELIAS DE OLIVEIRA, Vanessa. Processo de descentralização de políticas públicas e seu impacto sobre o federalismo brasileiro. In: TAVARES, André Ramos; BUCK, Pedro [coord.]. Revista Brasileira de Estudos Constitucionais. ano 5, n. 19. julho/setembro 2011.

FANTI, Fabíola. Políticas de saúde em juízo: um estudo sobre o Município de São Paulo. Dissertação de Mestrado defendida no Programa de Pós-Graduação da Faculdade de Filosofia, Letras e Ciências Humanas da Universidade de São Paulo. 2009.

FAZZALARI, Elio. Istituzioni di Diritto Processuale. VIII ed. Padova: CEDAM, 1996.

FERRAZ, Octávio L. Motta. Brasil: desigualdades en salud, derechos y tribunales. El impacto social de la judicialización de la salud. In: YAMIN, Alicia Ely; GLOPPEN, Siri [coord]. La lucha por los derechos de la salud. Buenos Aires: Siglo Veintiuno, 2013.

FIGUEIREDO, Tatiana Aragão. Análise dos medicamentos fornecidos por mandado judicial na Comarca do Rio de Janeiro: A aplicação de evidências científicas no processo de tomada de decisão. Dissertação de mestrado. FIOCRUZ. Rio de Janeiro, 2010. FILGUEIRAS, Fernando. Corrupção, democracia e legitimidade. Belo Horizonte: UFMG. 2008.

FRASCA, Raffaele. Note sui presupposti del litisconsorzio necessario I. In: Rivista di Diritto Processuale. Anno LIX. Seconda Serie. n. 2. abril-junh, 1999.

FREIRE JR. Américo Bedê. O Controle Judicial de Políticas Públicas. São Paulo: RT, 2005.

GAJARDONI, Fernando da Fonseca. Flexibilização Procedimental... São Paulo: Atlas. 2008.

GARCIA PELAYO, Manuel. Derecho constitucional comparado. 8. ed. Madrid: Revista de Ocidente, 1967.

GOMES, Emerson Cesar da Silva. A disciplina jurídica das transferências voluntárias. In: CONTI, José Maurício. SCAFF, Fernando Facury. [org.] Orçamentos Públicos e Direito Financeiro. São Paulo: RT, 2011.

GONÇALVES, William Couto. Intervenção de terceiros. Belo Horizonte: Del Rey, 1997. GRINOVER, Ada Pellegrini. O princípio da ampla defesa no processo civil, penal e administrativo. In: O processo em sua unidade - II. Rio de Janeiro: Forense, 1984. 
. A independência do juiz brasileiro. In: O Processo em sua unidade

- II. Rio de Janeiro: Forense, 1984.

Modernidade do direito processual brasileiro. In: O Processo em

Evolução. 2. ed. Rio de Janeiro: Forense, 1998.

. Princípios e Garantias Constitucionais. In: O Processo. III Série. P.

4)

.; DINAMARCO, Cândido Rangel; CINTRA, Antônio Carlos de Araújo. Teoria Geral do Processo. 19. Ed. São Paulo: Malheiros, 2003.

O controle de políticas públicas pelo Poder Judiciário. In:

GRINOVER, Ada Pellegrini. O Processo... 2. ed. rev.ampl. São Paulo: DPJ, 2009.

O controle jurisdicional de políticas públicas. In: GRINOVER, Ada

Pellegrini; WATANABE, Kazuo. O Controle Jurisdicional de Políticas Públicas. 2. ed.

Rio de Janeiro: Forense, 2013.

GUINCHARD, Serge. Droit et ratique de la Procédure Civile. 6. Ed. Paris : Dalloz, 2009.

GUILHERME DOS SANTOS, Wanderley. Cidadania e Justiça. A Política Social na

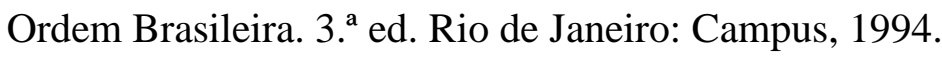

A coisa julgada no litisconsórcio facultativo unitário. $\mathrm{O}$ exemplo de ações coletivas e individuais no campo da saúde. Inédito.

HORTA, Raul Machado. Direito Constitucional. 2. Ed. Ver. Atual. Ampl. Belo Horizonte: Del Rey, 1999.

IMPERIALI, Stefano. L'ordinanza della corte costituzionale. n. 261 del 2006 e l'intervento iussu iudicis nel giudizio di responsabilita' amministrativa. Disponível em: http://www.amcorteconti.it/articoli/imperiali_iussu\%20iudicis.htm. Acesso em 15 de agosto de 2013.

IPEA. Políticas Sociais. Acompanhamento e Análise. n. 18. 2010. Saúde. Disponível em: http://www.ipea.gov.br/portal/images/stories/PDFs/politicas_sociais/bps_18_cap04.pdf

ITÁLIA. Cass. Civ. II Sez. n. 693 del 1980, Sez. Lav. n. 4000 del 1985, Sez. Lav. n. 5082 del 1995, I Sez. n. 5983 del 1999.

ITALIA. Cass. 19 gennaio 2004, n. 707. SUPREMA CORTE DI CASSAZIONE SEZIONE III CIVILE Sentenza 7 giugno -13 luglio 2011, n. 15387 (Presidente Morelli Relatore D'Alessandro). Disponível em: http://www.altalex.com/index.php?idnot=53236. 
ITALIA. Corte di Cassazione, Sez. 2, Sentenza n. 315 del 09/01/2013. Disponível em: http://www.foroeuropeo.it/index.php/civile-procedura/37495-civile-intervento-in-causadel-terzo-coatto-iussu-iudicis-chiamata.

ITALIA. Civ. 3e, 6 oct. 1993, no 91-15.728. Bull, civ III nº 118 ; JCP 1993, IV, 2540 ; RTD civ 1994, 163, obs. R. Perrot.

JACOB, Cesar Augusto Alckmin. A "reserva do possível": obrigação de previsão orçamentária e de aplicação da verba. In: GRINOVER, Ada Pellegrini; WATANABE, Kazuo. O Controle Jurisdicional de Políticas Públicas. 2. ed. Rio de Janeiro: Forense, 2013.

KUBLISCAS, Wellington Márcio. Cooperação Interfederativa. Instrumentos para a efetividade da lealdade federativa na Constituição Federal de 1988. Tese de Doutorado defendida no Programa de Pós Graduação em Direito da Universidade de São Paulo. 2012. LAPATZA, José Juan Ferreiro. Curso de derecho financiero español. Instituciones. 25. ed. Madrid: Marcial Pons, 2006.

LEBRÃO, Roberto Mercado. Federalismo e Políticas Sociais na Constituição de 1988. In: Federalismo Fiscal. Questões Contemporâneas. Florianópolis: Conceito Editorial, 2010.

LIEBMAN, Enrico Tullio. Manuale di Diritto Processuale Civile. I. Milano: Giuffré, 1980.

LÔBO DA COSTA, Moacyr. A intervenção iussu iudicis no processo civil brasileiro. São Paulo: Saraiva, 1961.

LOPES, José Reinaldo de Lima. Direitos Sociais, teoria e prática. São Paulo: Ed. Método. 2006.

MACHADO, Raquel Cavalcanti Ramos. A mudança do paradigma orçamentário... In: CONTI, José Maurício; SCAFF, Fernando Facury. Orçamentos Públicos e Direito Financeiro. São Paulo: RT, 2011.

MACHADO JR., José Teixeira; REIS, Heraldo Costa. A lei 4.320 comentada. 31. ed. rev. Atual. Rio de Janeiro: IBAM, 2002/2003.

MANCUSO, Rodolfo de Camargo. A Resolução dos Conflitos e a Função Judicial... São Paulo: RT. 2009.

MARINONI, Luiz Guilherme. Teoria Geral do Processo. São Paulo: RT, 6. ed. 2012. MARQUES NETO, Floriano Azevedo. Parecer sobre o Projeto de Lei no 3884/2004. Disponível em: www.cidades.gov.br/media/ConsorcioPublico/ParecerFlorianoAzevedoMarquesNeto.pdf. 
MICHELE, Gian Antonio. Opera Minori di Diritto Processuale Civile. vol. I. Milão: Giuffrè, 1982.

MIRANDA, Jorge. Manual de Direito Constitucional. Tomo IV. 4. ed. Coimbra: Coimbra Editora, 2008.

MORAES, Maria Celina Bodin de. O princípio da solidariedade. Disponível em: http://www.tepedino.adv.br/wp/wp-content/uploads/2012/09/biblioteca9.pdf.

MOREIRA NETO, Diogo de Figueiredo. A competência legislativa e executiva dos Municípios em matéria ambiental. In: Revista de Informação Legislativa. ano 28. nº111. jul/ set. 1991. Brasília: Senado Federal.

MORTARA, Lodovico. Commentario del Codice di Procedura Civile. Vol III. Milano, 1923.

MOURAO, Paulo Reis; CUNHA, Eurico José A. Políticas Pork Barrel: um estudo sobre o caso português do PIDDAC. Disponível em: http://www.proppi.uff.br/revistaeconomica/sites/default/files/Politicas_Pork_Barrel__Um_estudo_sobre_o_caso_portugues_do_PIDDAC.pdf.

NOVAIS, Jorge Reis. Direitos Sociais. Teoria Jurídica dos Direitos Sociais enquanto Direitos Fundamentais. Coimbra: Wolters Kluwer. 2010.

OATES, Wallace E. Fiscal Federalism. Harcourt Brace Jovanovich, 1972.

OLIVEIRA, Regis Fernandes. Introdução. In: CONTI, José Maurício et alli. [org.] Federalismo Fiscal. Questões Contemporâneas. Florianópolis: Conceito Editorial, 2010. . Curso de Direito Financeiro. 4. ed. rev. atual. ampl. São Paulo: RT, 2011.

OLIVEIRA E ARAÚJO, João Batista. Avanços e impasses na educação: à guisa do balanço. p. 16-27, jan./mar. 1998.

PELLEGRINI, Flaviane de Magalhães Barros. O processo, a jurisdição e a ação sob a ótica de Elio Fazzalari. Disponível em: https:/ /www.google.com.br/url?sa=t\&rct=j\&q=\&esrc=s\&source=web\&cd=3\&cad=rja\&ved=0CE UQFjAC\&url=http\%3A\%2F\%2Fwww.fmd.pucminas.br\%2FVirtuajus\%2FAno2_08_2003 _arquivos\%2FDocente\%2FO\%2520PROCESSO \%2C\%2520A\%2520JURISDI\%25C7\%25 C3O $\% 2520 \mathrm{E} \% 2520 \mathrm{~A} \% 2520 \mathrm{~A} \% 25 \mathrm{C} 7 \% 25 \mathrm{C} 3 \mathrm{O} \% 2520 \mathrm{SOB} \% 2520 \mathrm{~A} \% 2520 \% 25 \mathrm{D} 3 \mathrm{TICA} \%$ 2520DE\%2520ELIO\%2520FAZZALARI.doc\&ei=YjNnUuToHsj02wXd94HQBw\&usg= AFQjCNEUwNc9BrQsz2upDkFsKsZL6Jp4_g\&sig2=HCoB0IY77WMaxmEHsArsSg. PICARDI, Nicola. Il principio del contraddittorio. In: Rivista di Diritto Processuale. Padova: CEDAM. 
PROTO PISANI, Andrea. Appunti sul litisconsorzio necessario e sugli interventi. In: Rivista di Diritto Processuale. Anno XLIX. 2. ed. n. 1. jan-mar, 1994.

PROTO PISANI, Andrea. Per un nuovo codice di procedura civile. Disponível em: https:/

/www.academia.edu/210012/Andrea_Proto_Pisani_Il_progetto_di_un_nuovo_codice_di_p rocedura_civile_2009. Acesso em: 03 de julho de 2013.

QUEIROZ, Cristina. Direitos Fundamentais Sociais... Coimbra: Coimbra Editora. 2006. REDENTI, Enrico. Il giudizio civile con pluralità di parti. Milano, 1911.

Profili Pratici del Diritto Processuale Civile. 2. ed. rev.

Milão:Giuffrè. 1939.

RIBEIRO, Maria de Fátima. Efetivação de Políticas públicas: uma questão orçamentária. In: CONTI, José Maurício; SCAFF, Fernando Facury. Orçamentos Públicos e Direito Financeiro. São Paulo: RT, 2011.

RÍOS, Luiz Carlos Alzate. El Estado de Cosas Inconstitucional. Disponível em: http:/ /www.egov.ufsc.br/portal/conteudo/el-estado-de-cosas-inconstitucional.

ROCHA, Cármen Lúcia Antunes. República e Federação no Brasil. Traços constitucionais da organização política brasileira. Belo Horizonte: Del Rey, 1996.

ROVIRA, Enoch Alberti. Federalismo y cooperacion em la República Federal Alemana. Madrid: Centro de Estudios Constitucionales, 1986.

SADEK, Maria Tereza. Judiciário e Arena Pública: um olhar a partir da ciência. In: GRINOVER, Ada Pellegrini; WATANABE, Kazuo. O Controle Jurisdicional de Políticas Públicas. 2. ed. Rio de Janeiro: Forense, 2013.

SAKURAI, Sergio Naruhiko et ali. Emenda constitucional no 29/2000: influência sobre a execução orçamentária dos Estados e municípios brasileiros em saúde. In: BLIACHERIENE, Ana Carla; SANTOS, José Sebastião [org.] Direito à vida e à saúde. Impactos orçamentário e judicial. São Paulo: Atlas, 2010.

SALLES, Carlos Alberto de. Processo Civil de Interesse Público In: SALLES, Carlos Alberto de. Processo Civil e Interesse Público... São Paulo: RT, 2003.

SALLES, Carlos Alberto de . Políticas públicas e processo: a questão da legitimidade nas ações coletivas. In: BUCCI, Maria Paula Dallari. [org.]. Políticas Públicas: reflexões sobre o conceito jurídico. $1^{\text {a }}$ ed. São Paulo: Saraiva, 2006.

SANTANA, José Lima. O princípio constitucional da eficiência e o Sistema Único de Saúde (SUS). In: BLIACHERIENE, Ana Carla; SANTOS, José Sebastião [org.] Direito à vida e à saúde. Impactos orçamentário e judicial. São Paulo: Atlas, 2010. 
SANTOS, Lenir. SUS e a Lei Complementar 141 comentada. Campinas: Saberes, 2012. Lei 8.080/90 é regulamentada 21 anos depois: Decreto 7508/2011.

Disponível em: http://blogs.bvsalud.org/ds/2011/07/16/lei-8-08090-e-regulamentada-21anos-depois-decreto-75082011/.

SARLET, Ingo Wolfgang Sarlet. Direitos Fundamentais Sociais e proibição do retrocesso: algumas notas sobre o desafio da sobrevivência dos Direitos Sociais num contexto de crise. In: Revista do Instituto de Hermenêutica Jurídica. Porto Alegre: IHJ, n. 2, 2004.

SATTA, Salvatore. Diritto processuale civile. 6. Ed. Riv. Cor. Padova: CEDAM, 1959. L’intervento ordinato dal Giudice. In: Scritti di diritto e di economia in onore di Flaminio Mancaleoni. Sassari: Gallizzi, 1938.

Commentario al codice di procedura civile. Libro primo. Milão: Casa Editrice Dr. Francesco Vallardi, 1959.

SCAFF, Fernando Facury. Reserva do possível, mínimo existencial e direitos humanos. In: PIRES, Adilson Rodrigues. TORRES, Heleno Taveira (org.). Princípios de direito financeiro e tributário. Estudos em homenagem ao Professor Ricardo Lobo Torres. Rio de janeiro: Renovar, 2006.

SEGNI, Antonio. L intervento adesivo. Roma, 1919.

SILVA, José Afonso da. Orçamento-programa no Brasil. São Paulo: Editora Revista dos Tribunais, 1973.

SILVEIRA, Alessandra. Cooperação e compromisso constitucional nos Estados Compostos. Estudo sobre a teoria do federalismo e a organização jurídica dos sistemas federativos. Coimbra: Almedina, 2007.

SMULOVITZ, Catalina; URRIBARRI, Daniela. Poderes Judiciales en America Latina...In: Cohesión social en América Latina: bases para una nueva agenda democrática. Disponível em: www.plataformademocratica.org.

SOARES, Márcia Miranda. Federalismo e desigualdades no Brasil atual. In: TAVARES, André Ramos; BUCK, Pedro [coord.]. Revista Brasileira de Estudos Constitucionais. ano 5, n. 19. julho/setembro 2011.

SORJ, Bernardo. Transcrição disponível em: www.bernardosorj.com. Acesso em: 28 de fevereiro de 2009.

SOUZA, Celina. Estado da Arte da Pesquisa em Políticas Públicas. In: HOCHMAN, Gilberto et alli. [org.] Políticas Públicas no Brasil. Rio de Janeiro: FIOCRUZ, 2007. 
TAVARES DE ALMEIDA, Maria Hermínia. Prefácio. In: ARRETCHE, Marta. Democracia, federalismo e centralização no Brasil. Rio de Janeiro: FGV; Fiocruz, 2012. p. 16.

TELLES, Vera. Direitos sociais... 2. reimp. Belo Horizonte: UFMG. 2006.

TER-MINASSIAN, Teresa. Brazil. In: TER-MINASSIAN, Teresa [edit]. Fiscal Federalism in Theory and Practice. Washington: International Monetary Fund. 1997.

TROCKER, Nicolò. Intervento per ordine del giudice. Milano: Giuffré, 1984.

VIEIRA, F. S. Ações judiciais e o direito à saúde: reflexão sobre a observância aos princípios do SUS. Revista de Saúde Pública, 42 (2), 2008.

WANG, Daniel Wei Liang. Poder Judiciário e participação democrática nas políticas de saúde. Dissertação de mestrado defendida no Programa de Pós Graduação em Direito da Universidade de São Paulo. 2009.

WATANABE, Kazuo. Controle Jurisdicional das Políticas Públicas - Mínimo existencial e demais direitos fundamentais imediatamente judicializáveis. In: GRINOVER, Ada Pellegrini; WATANABE, Kazuo [coord.]. O Controle Jurisdicional de Políticas Públicas. Rio de Janeiro: Forense, 2011.

WATANABE, Kazuo. Cognição no Processo Civil. São Paulo: Saraiva. 2012.

WEICHERT, Marlon Alberto. O Sistema Único de Saúde no federalismo brasileiro. In: Revista de Direito Constitucional e Internacional. Ano 8. n. 32. São Paulo: RT, jul-set. 2000.

XIMENES, Salomão Barros. Vinculação de Recursos e Desequilíbrios no Financiamento da Educação. In: CONTI, José Maurício et alli. [org.] Federalismo Fiscal. Questões Contemporâneas. Florianópolis: Conceito Editorial, 2010.

YEPES, Rodrigo U. La judicialización de la política en Colombia: casos, potencialidades y riesgos. In: PALACIO, Juan Manuel; CANDIOTI, Magdalena [comp]. Justicia, política y derechos en América Latina. Buenos Aires: Prometeo, 2007

ZAGRABELSKY, Gustavo. EI derecho dúctil: ley, derechos e justicia. Madrid: Editorial Trotta. 1995.

ZAVASCKI, Teori Albino. Eficácia social da prestação jurisdicional. Disponível em: https:/

/www.google.com.br/url?sa=t\&rct=j\&q=\&esrc=s\&source=web\&cd=1\&ved=0CC0QFjAA \&url=http\%3A\%2F\%2Fwww2.senado.leg.br\%2Fbdsf\%2Fhandle\%2Fid\%2F176210\&ei=g svUUsfuG5C4kQeOiYDYCg\&usg=AFQjCNE2BNbG8qwfMYL_Lq5uhfjqa6yXLg\&sig2 =MeZ-2mCyPte0yl6JyChPJAP. 293-4. 
ZIMMERMAN, Augusto. Teoria Geral do Federalismo Democrático. 2. Ed. Rio de Janeiro: Lumen Juris, 2005.

ZUCCHI, Paola; VIEIRA, Fabiola Sulpino. Distorções causadas pelas ações judiciais à política de medicamentos no Brasil. In: Revista Saúde Pública 2007; 41(2): 214-22.

ZUFELATO, Camilo. Controle Judicial de Políticas Públicas mediante Ações Coletivas e Individuais. In: GRINOVER, Ada Pellegrini; WATANABE, Kazuo. [coord.]. O Controle Jurisdicional de Políticas Públicas. 2. ed. Rio de Janeiro: Forense, 2013. 